UNIVERSIDADE DE SÃO PAULO

FACULDADE DE MEDICINA DE RIBEIRÃO PRETO

PÓS-GRADUAÇÃO EM IMUNOLOGIA BÁSICA E APLICADA

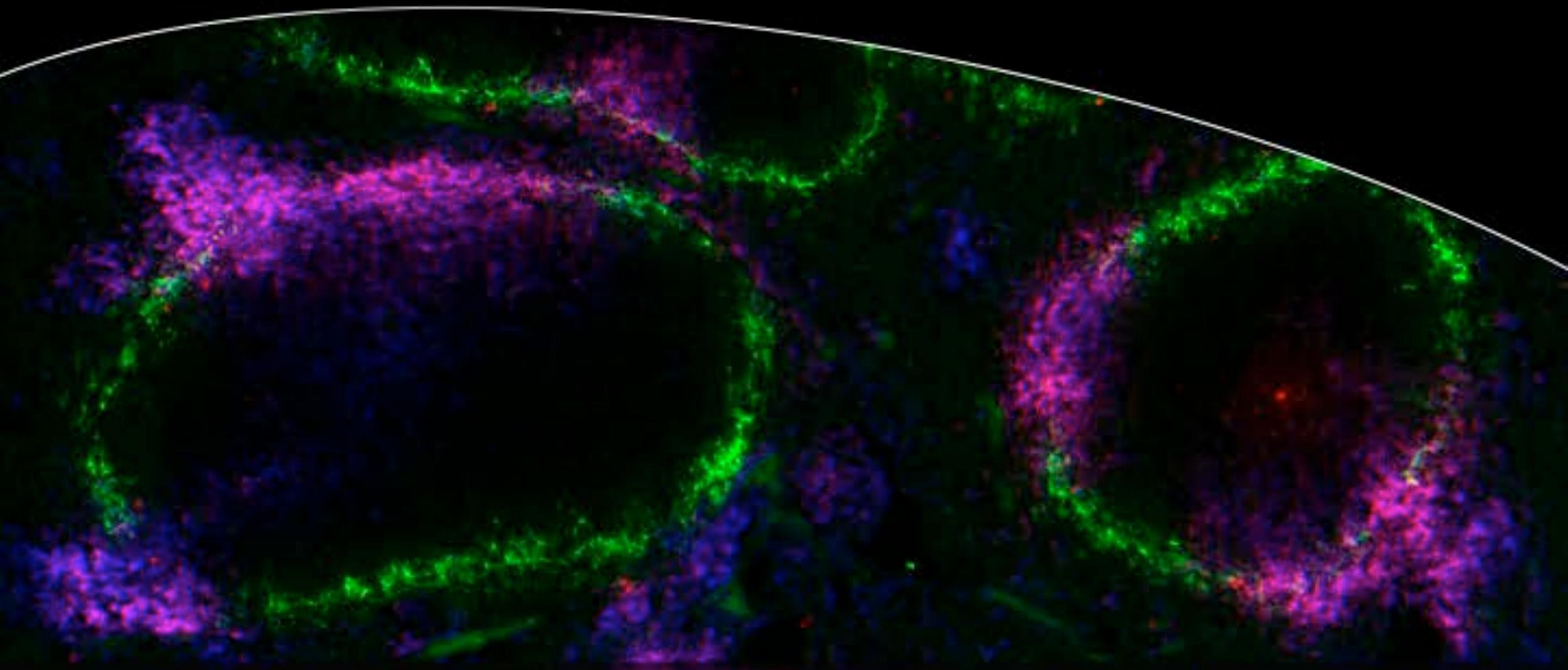

A sinalização via NOD2-RIP2 modula a imunidade adaptativa contra Leishmania infantum

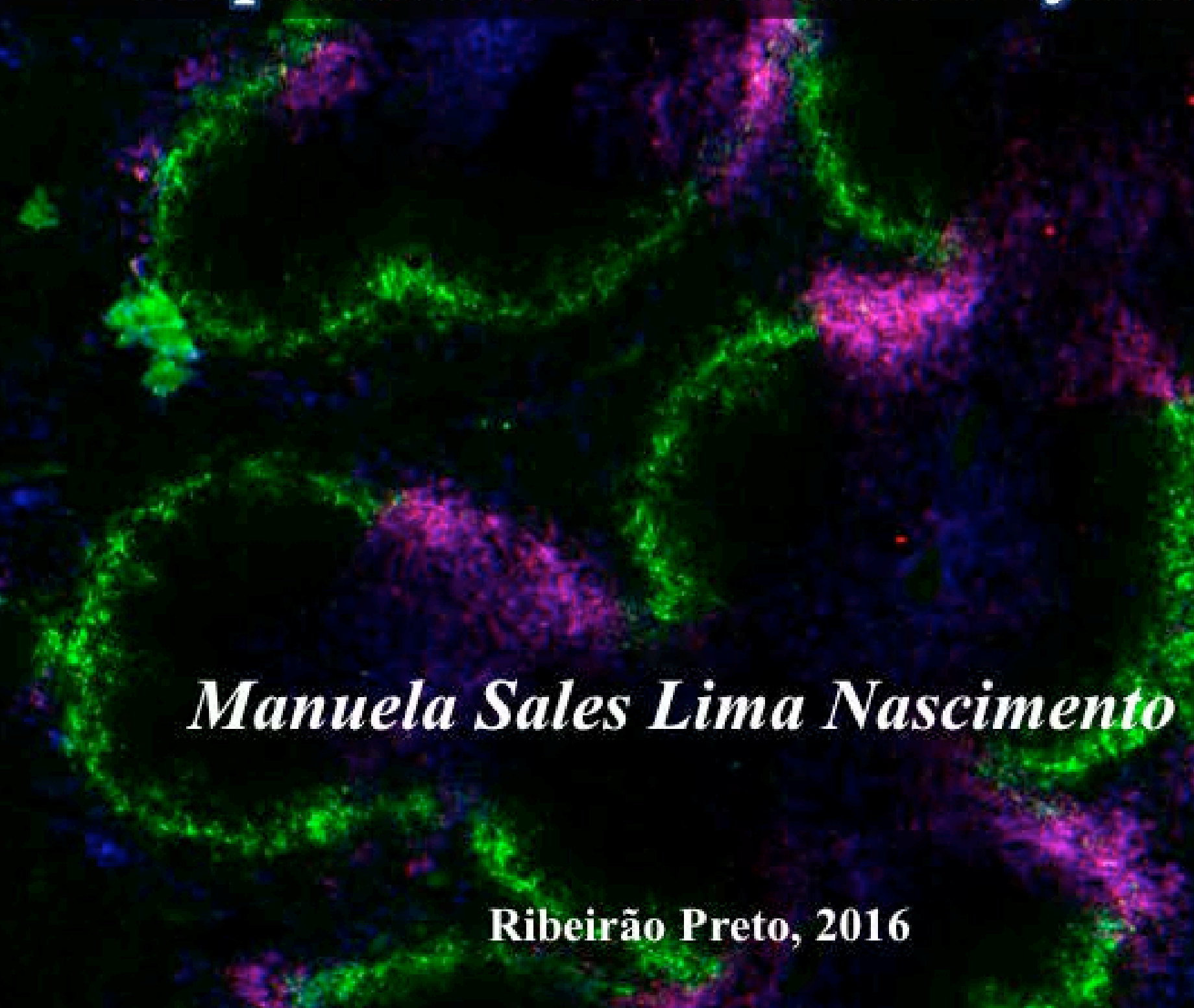


UNIVERSIDADE DE SÃO PAULO

FACULDADE DE MEDICINA DE RIBEIRÃO PRETO

PÓS-GRADUAÇÃO EM IMUNLOGIA BÁSICA E APLICADA

\section{A sinalização via NOD2-RIP2 modula a imunidade adaptativa contra Leishmania infantum}

Manuela Sales Lima Nascimento

Ribeirão Preto - SP

2016 
A sinalização via NOD2-RIP2 modula a imunidade adaptativa contra Leishmania infantum

Tese apresentada ao curso de Pós-graduação em Imunologia Básica e Aplicada da Faculdade de Medicina de Ribeirão Preto da Universidade de São Paulo, para obtenção do grau de Doutor em Ciências.

Área de concentração: Imunologia Básica e Aplicada.

Orientador: Prof. Dr. João Santana da Silva.

Ribeirão Preto - SP 
FICHA CATALOGRÁFICA

Nascimento, Manuela Sales Lima

A sinalização via NOD2-RIP2 modula a imunidade adaptativa contra Leishmania infantum.

Ribeirão Preto, 2016.

$166 \mathrm{p}$ : il:30 cm

Tese de doutorado apresentada à Faculdade de Medicina de Ribeirão Preto/USP. Área de concentração: Imunologia Básica e Aplicada.

Orientador: Silva, João Santana.

1. Leishmania infantum, 2. NOD2, 3. RIP2, 4. células dendríticas, 5 . imunidade adaptativa. 
Trabalho realizado no Laboratório de Imunoparasitologia, Departamento de Bioquímica e Imunologia da Faculdade de Medicina de Ribeirão Preto da Universidade de São Paulo, e no Departamento de Medicina Laboratorial da Universidade de Yale. O trabalho recebeu auxílio financeiro do Núcleo de Apoio à Pesquisa em Doenças Inflamatórias (processo $N^{o}$ 11.1.21625.01.0), FAPESP (processos $\mathrm{N}^{\mathrm{o}}$ 2012/14524-9; 2013/01967-2 e 2014/10347-0), Capes/INCT e CNPQ. 
Nome: NASCIMENTO, Manuela Sales Lima

Título: A sinalização via NOD2-RIP2 modula a imunidade adaptativa contra Leishmania infantum

Tese apresentada ao curso de Pós-graduação em Imunologia Básica e Aplicada da Faculdade de Medicina de Ribeirão Preto da Universidade de São Paulo, para obtenção do grau de Doutor em Ciências Área de concentração: Imunologia Básica e Aplicada

Aprovado (a) em:

\section{Banca Examinadora}

Prof. Dr. João Santana da Silva Instituição: Faculdade de Medicina de Ribeirão Preto USP Julgamento: Assinatura:

Prof. Dr. Instituição:

Julgamento: Assinatura:

Prof. Dr. Instituição:

Julgamento: Assinatura:

Prof. Dr. Instituição:

Julgamento: Assinatura: 
Dedico esse trabalho aos meus pais, irmão e noivo, por abraçarem meus sonhos como se fossem deles próprios. Por vibrarem e sofrerem junto comigo a cada vitória e a cada tropeço. Toda a conquista é para vocês! 


\section{AGRADECIMENTOS}

O meu primeiro obrigada é dedicado ao meus pais, Goiamir e Regina, ao meu noivo, Paulo, e ao meu irmão, Felipe. Por me permitirem desfrutar de toda a plenitude de uma família que conforta, alivia e fortalece. Obrigada por acreditarem em mim e me ajudarem a superar todos os obstáculos durante o período da pós-graduação. Agradeço também a todos os membros das famílias Sales e Nascimento/Segurado que direta ou indiretamente contribuíram para minha formação.

Ao Prof. Dr. João Santana por me permitir ter chegado onde cheguei. Obrigada pelos anos de convivência, por todos os ensinamentos e exemplos de dedicação à ciência, pelo apoio e incentivo durante meus cursos de mestrado e doutorado e por toda contribuição para o meu crescimento científico e intelectual.

À Profa. Dr ${ }^{\mathrm{a}}$. Stephanie Eisenbarth por ter me dado a oportunidade de aprender e trabalhar com uma equipe fantástica de pesquisadores. Vocês contribuíram consideravelmente para a minha formação.

Aos professores Dr. Dario Zamboni e Dr. Thiago Cunha, pela atenção, apoio e discussões científicas. E aos professores Dr. Roque Pacheco de Almeida, Dr ${ }^{\mathrm{a}}$. Amélia Maria de Jesus e Dr ${ }^{\mathrm{a}}$ Vanessa Carregaro pela excelente colaboração.

Aos meus amigos e também colaboradores desse trabalho Marcela Davoli, Gustavo Quirino, Denise Morais, Jonilson Berlink, Jayendra K. Krishnaswamy, Dong Liu e Sandra Maruyama. Obrigada por toda a dedicação e amizade ao longo desses anos. Sem a ajuda de vocês nada disso seria possível.

Aos demais companheiros do laboratório do Prof. Dr. João Santana da Silva e da Prof. ${ }^{\text {a }}$ $\mathrm{Dr}^{\mathrm{a}}$. Stephanie Eisenbarth por me proporcionarem tanta aprendizagem.

Aos amigos que fiz nesse período de pós-graduação, Patrícia Reis, Letícia Magalhães, Elen Anatriello, Alynne Karen, Kalil Alves, Francielle Guimarães, Luís Gustavo, Gustavo 
Garcia, Mikhael Haruo, Fernanda Agostini, Camila Matsumoto, Aline Sardinha, Diego Costa, Djalma Lima-Júnior, Fausto Almeida, Raphael Sanches, Tatyana Cecilio, Maria Fernanda.

Ao apoio técnico, Denise Ferraz, Cristiane Milanezi, Wander Ribeiro, Rubilan Quinero, Júlio Anselmo e Dener Reis por todo o auxílio para a execução dos meus experimentos; e à secretária Ana Cristine pelo profissionalismo e disposição sempre que precisei.

Obrigada aos membros da banca pela disponibilidade de avaliar e contribuir para a melhoria do meu trabalho.

À FAPESP, CAPES/INCT, CNPq e FAEPA pelo incentivo financeiro através da concessão da bolsa, bem como pelo apoio para a participação em eventos científicos.

Os meus mais sinceros agradecimentos!

"Agradeço todas as dificuldades que enfrentei; não fosse por elas, eu não teria saído do lugar. As facilidades nos impedem de caminhar..." 
Epigrafe

"A tarefa não é tanto ver aquilo que ninguém viu, mas pensar o que ninguém ainda pensou sobre aquilo que todo mundo vê." Arthur Schopenhauer 


\section{ÍNDICE}

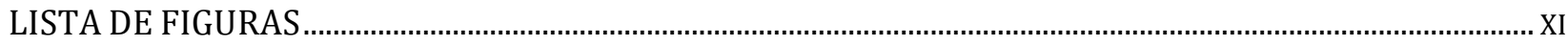

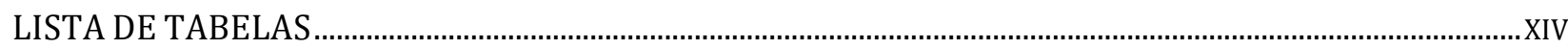

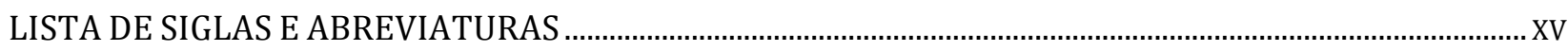

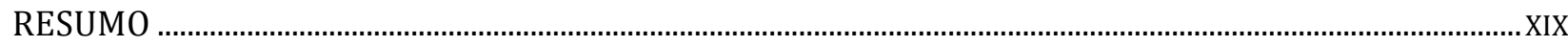

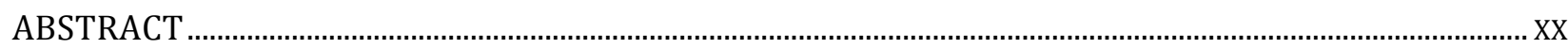

I. INTRODUÇÃO

1.1 - LEISHMANIOSE: CARACTERÍSTICAS GERAIS E EPIDEMIOLOGIA ……............................................................. 22

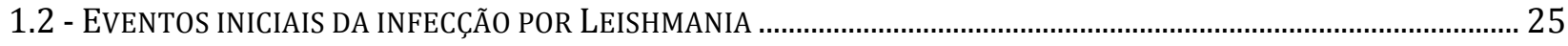

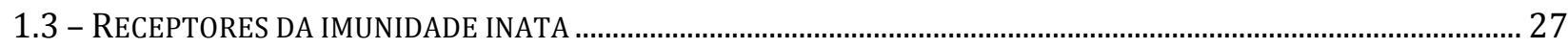

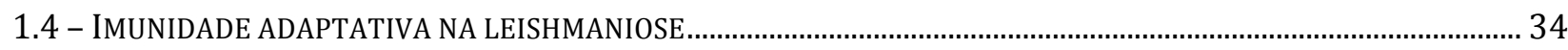

II. OBJETIVO

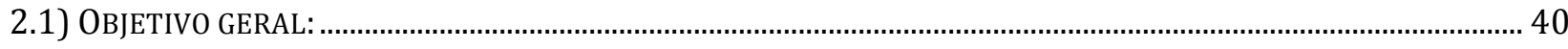

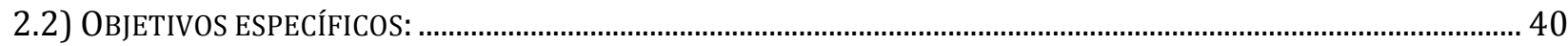

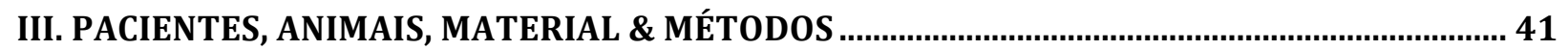

3.1 - PACIENTES, INDIVÍDUOS ASSINTOMÁTICOS, SUJEITOS CONTROLES E RNASEQ ……......................................... 42

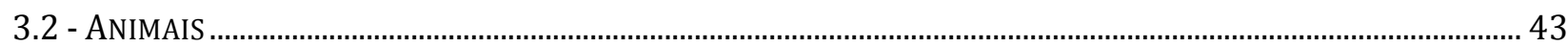

3.3 - PARASITOS E INFECÇÃO EXPERIMENTAL

3.4 - PCR ARRAY

3.5 - DIFERENCIAÇÃO DE CÉLULAS DENDRÍTICAS E INFECÇãO IN VITRO …………................................................ 45

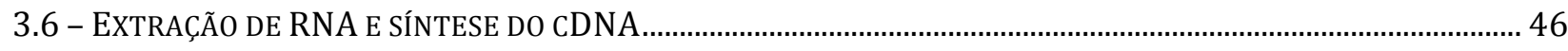

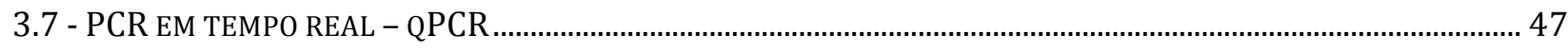

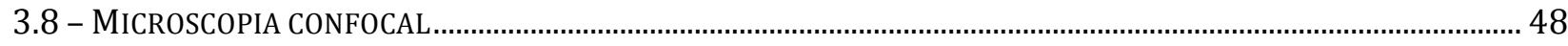

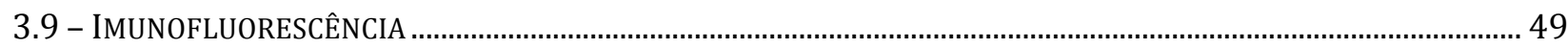

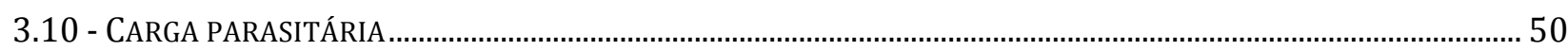

3.11 - DOSAGEM DE CITOCINAS POR ELISA ………………............................................................................. 51

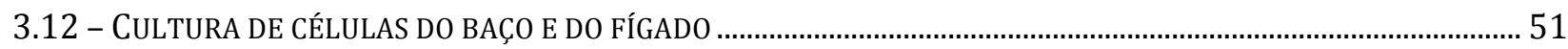

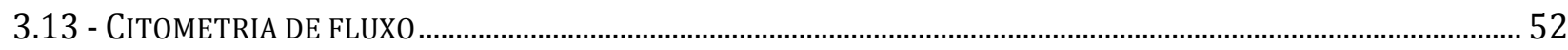

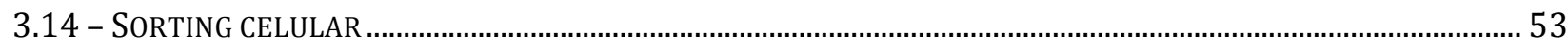

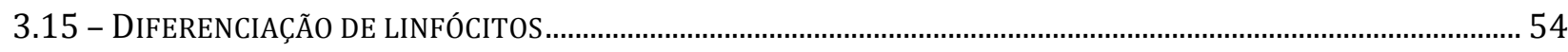

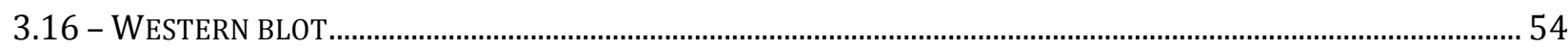

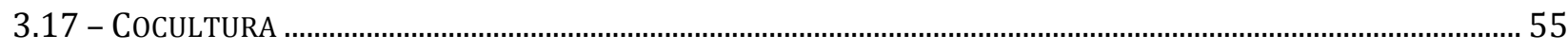

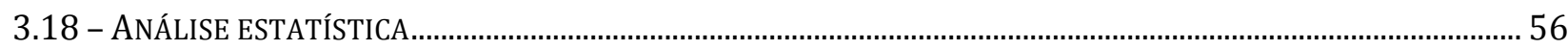

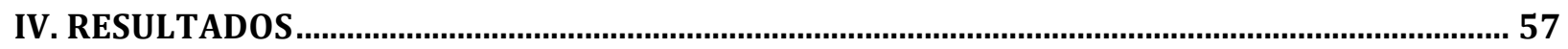


4.1 - CÉLULAS TH17 SÃO INIBIDAS DURANTE A LEISHMANIOSE VISCERAL POR LEISHMANIA INFANTUM 58

4.2 - LEISHMANIA INFANTUM INDUZ A EXPRESSÃO DE NOD2, O QUAL MODULA A RESPOSTA IMUNE ADAPTATIVA.

4.3 - A VIA DE SINALIZAÇÃO DE NOD2-RIP2 POSSUI PAPEL EXTRÍNSECO NA MODULAÇ̃̃O DA POLARIZAÇÃO DE LINFÓCITOS TH1 E TH17

4.4 - CÉLULAS DENDRÍTICAS CD8 $\alpha \alpha^{+}$SÃO IMPORTANTES PARA POLARIZAÇÃO DE CÉLULAS TH1, MAS NÃO DE LINFÓCITOS TH17 DURANTE A INFECÇÃO POR L. INFANTUM

\section{$X$. ANEXOS}

ANEXo 1 - CERTIFICAdo de APROVAÇÃo PELO Comitê de ÉTICA HuMANo.

ANEXo 2 - CERTIFICADO DE APROVAÇ̃̃o PELO COMITÊ DE ÉTICA EM EXPERIMENTAÇ̃̃o ANIMAL 133

ANEXO 3 - MANUSCRITO 


\section{LISTA DE FIGURAS}

Figura 1: Tipos celulares envolvidos na fagocitose da Leishmania nos momentos iniciais da infecção.

Figura 2: Representação esquemática da sinalização inicial via NOD2

Figura 3: Regulação da expressão de genes relacionados às respostas Th1 e Th17 em leucócitos de sangue periférico humano. 59

Figura 4: Células B CD19 ${ }^{+} \mathrm{CD}^{-} \mathrm{TCR}^{-}{ }^{-}$são a importante fonte de IL-17A durante a infecção por L. infantum .60

Figura 5: Integridade e qualidade do RNA extraído do fígado de camundongos não infectados (NI) e na $4^{\mathrm{a}}$ e $6^{\mathrm{a}}$ semanas após a infecção (s.a.i.).

Figura 6: Análise do PCR array do fígado de camundongos após 4 e 6 semanas de infecção (comparado com controle não infectado).

Figura 7: A expressão de transcritos de Ifng, Tbx21 e $I l 17 a$ são induzidos, mas o RNAm de Rorc é reprimido após a infecção por L. infantum. . .64

Figura 8: A infecção por L. infantum induz a expressão de RNAm de Nod2 e Rip2 no fígado de camundongos. 66 
Figura 9: L. infantum induz a expressão de RNAm de Nod2 e Rip2 em BMDCs .66

Figura 10: NOD2 colocaliza com o parasito na célula dendrítica infectada. .68

Figura 11: Células Th17 são inibidas pela via de NOD2-RIP2 69

Figura 12: Camundongos $N o d 2^{-/-}$e Rip2 $2^{-/-}$são mais suscetíveis a infecção por L. infantum.......70

Figura 13: Células Th1 são induzidas pela via de NOD2-RIP2. 71

Figura 14: NOD2 e RIP2 não exercem papel intrínseco na diferenciação de linfócitos. 72

Figura 15: A expressão de NOD2 e RIP2 em células dendríticas modula a diferenciação de linfócitos $\mathrm{T} \mathrm{CD} 4^{+}$ .74

Figura 16: NOD2 e RIP2 não interferem na diferenciação de BMDCs. .76

Figura 17: A ausência de NOD2 e RIP2 não compromete a capacidade de ativação das BMDCs. .77

Figura 18: NOD2 e RIP2 induzem a produção de IL-12p35 e IL-12p70 mas inibem a produção de IL-12/23p40 e IL-23 em células dendríticas infectadas com L. infantum. .78

Figura 19: A fosforilação de p38 e JNK são prejudicadas na ausência de NOD2 e RIP2. .79 
Figura 20: Células dendríticas $\mathrm{CD} 4^{+}$e CD8$\alpha \alpha^{+}$expressam Nod2 e Rip2

Figura 21: Camundongos $\operatorname{Nod}^{-/-}$e $\operatorname{Rip}^{-/-}$apresentam as populações de células dendríticas $\mathrm{CD}^{+} 33 \mathrm{D} 1^{+}$e $\mathrm{CD} 8 \alpha \alpha^{+} \mathrm{XCR}^{+}$em quantidades e orientação espacial comparadas aos WT........83

Figura 22: Camundongos Batf $^{-/-}$possuem menos células Th1 e mais células Th17 após infecção com L. infantum. .84

Figura 23: Modelo proposto - A sinalização via NOD2-RIP2 contribui para a modulação da imunidade adaptativa celular durante a infecção por Leishmania infantum. 103 


\section{LISTA DE TABELAS}

Tabela I: Pacientes e sujeitos controles envolvidos no estudo. .42

Tabela II: Sequência dos primers utilizados nas reações de PCR em tempo real .48

Tabela III: Protocolo de diferenciação de linfócitos T in vitro.

Tabela IV: Alterações na expressão gênica no fígado de camundongos WT; 4 e 6 semanas após a infecção (s.a.i.) com L. infantum. .64 


\section{LISTA DE SIGLAS E ABREVIATURAS}

$\underline{\mathbf{A}}$

APC - Célula apresentadora de antígeno

AIM - absent-in-melanoma

ALR - Receptores do tipo AIM

ASC - Apoptosis-associated Speck-like protein containg a CARD

ATG16L1 - Autophagy-related protein 16-like 1

B

BATF3: Basic leucin zipper transcription factor, ATF-like 3

BMDC: Células dendríticas derivadas de precursores da medula óssea

$\underline{\mathbf{C}}$

CARD - Domínio de recrutamento de caspase

CD - Cluster of differentiation

$\mathrm{Ct}$ - cicle threshold

CTL - C-type lectins

cDCs - Células dendríticas convencionais

\section{D}

DAMPs - Padrões moleculares associados a danos

DTH - hipersensibilidade do tipo tardio

$\underline{\mathbf{E}}$

e. g. - exempli gratia

$\underline{\mathbf{F}}$

FRMPD2 - PDZ-domain-containing 2

H

HMGB1 - high mobility group protein B1 
HPRT - Hypoxanthine-guanine phosphoribosyltransferase

I

iE-DAP - ácido $\gamma$-D-glutamil-meso-diaminopimélico

IFN - Interferon

IL - Interleucina

IRF - Fator regulador de interferon

$\underline{\mathbf{L}}$

LC - Leishmaniose cutânea

LM - Leishmaniose mucocutânea

LPS - Lipopolissacarídeo

LRR - Região rica em leucina

LV - Leishmaniose visceral

\section{$\underline{\mathbf{M}}$}

MAL - MyD88-adaptor-like

MAPK - mitoge nactivated protein kinases

MDP - Muramil dipeptídeo

MyD88 - Myeloid differentiation primary response gene 88

moDCs - Células dendríticas monocíticas

$\underline{\mathbf{N}}$

$\mathrm{NF}-\kappa \mathrm{B}$ - fator nuclear $\kappa \mathrm{B}$

NLR - Receptor do tipo NOD

NLRP - NLR family, pyrin domain containing

Nlrp3 - NLR family, pyrin domain containing 3 
NK - Células Natural Killer

NO: Óxido nítrico

NOD - Nucleotide-binding oligomerization domain

Nod1 $1^{-/}$- Deleção homozigótica do gene Nod1

$\operatorname{Nod} 2^{-/-}$- Deleção homozigótica do gene Nod2

NOS2 - Óxido nítrico sintase 2

$\underline{\mathbf{O}}$

OMS - Organização Mundial de Saúde

$\underline{\mathbf{P}}$

PAMP - Padrão molecular associado a patógeno

PBMC - células mononucleares de sangue periférico

PBS - Salina tamponada com fosfato

PGN - Peptideoglicano

PRRs - Receptores de reconhecimento padrão

pDCs - Células dendríticas plasmocitóides

$\underline{\mathbf{R}}$

RIG-I - retinoic acid-inducible gene-I

RIP2 - Receptor-interacting serine-threonine kinase 2

RLR - Receptores do tipo RIG

$\underline{\mathbf{T}}$

TGF $\beta$ - Transforming growth factor beta 
TLR - Receptores do tio Toll

TIRAP - TIR-containing adaptor protein

$\mathrm{Th}-\mathrm{T}$ helper

TNF- $\alpha$ - Fator de necrose tumoral alfa

T regs - Células T reguladoras

TRIF - TIR-containing adaptor-inducing

$\underline{\mathbf{W}}$

WT - Wild type

$\underline{\mathbf{Z}}$

ZM - Zona marginal 


\section{RESUMO}

\section{A sinalização via NOD2-RIP2 modula a imunidade adaptativa contra Leishmania infantum}

Células produtoras de IFN- $\gamma$ e IL-17A são envolvidas na proteção contra infecção por Leishmania infantum (L. infantum). Ainda não está claro como o sistema imune coordena, ou o parasito manipula, o balanço entre Th1 e Th17 durante a leishmaniose visceral (LV). Utilizando RNAseq, PCR array e citometria de fluxo, nós demonstramos que, enquanto o padrão Th1 é altamente induzido, o perfil Th17 é inibido durante a infecção por L. infantum, e que as células B compõem uma fonte importante de IL-17A nesse modelo. Usando animais $\mathrm{Nod}^{-/-}$e Rip $2^{-/-}$ nós caracterizamos essa via como um regulador negativo de células Th17 na LV. Por outro lado, a potente indução de Th1 foi dependente da sinalização via NOD2-RIP2 em células dendríticas CD8 $\alpha \alpha^{+} \mathrm{XCR}^{+}$, o que foi crucial para produção de IL-12 através da fosforilação de p38 e JNK. Como consequência, camundongos $N o d 2^{-/-}$e Rip $2^{-/-}$tiveram defeito na resposta Th1, aumento de Th17, e maiores cargas parasitárias comparado com camundongos WT. Juntos, os dados mostram que a via de NOD2-RIP2 desempenha um papel importante na modulação da resposta imune adaptativa e promove proteção contra LV causada por L. infantum.

Palavras chave: Leishmania infantum, NOD2, RIP2, células dendríticas, imunidade adaptativa. 


\begin{abstract}
NOD2-RIP2-mediated signaling contributes to shape adaptive immunity in visceral leishmaniasis
\end{abstract}

IFN- $\gamma$ and IL-17A-producing cells are described to be related to protection against Leishmania infantum (L. infantum) infection. How the immune system coordinates, or the parasite manipulates, the balance between Th1 and Th17 during visceral leishmaniasis (VL) is still unknown. We showed here that Th17 is suppressed during L. infantum infection and B cells

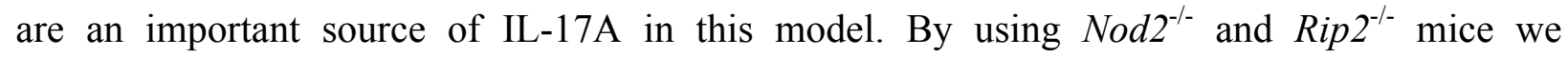
characterized this pathway as a negative regulator for Th17 cells in VL. On the other hand, the high level of Th1 induction was dependent on the NOD2-RIP2 signaling in $\mathrm{CD} 8 \alpha^{+} \mathrm{XCR} 1^{+}$ dendritic cells (DCs), which was crucial for IL-12 production through the phosphorylation of p38 and JNK. As a consequence, Nod2 $2^{-/}$and Rip $2^{-/-}$mice showed a Th1 defective response, more Th17, and higher parasite loads compared to WT mice. Together, the data demonstrate that NOD2-RIP2 signaling pathway plays a role in shaping adaptive immunity and promotes protection against VL caused by L. infantum.

Keywords: Leishmania infatum, NOD2, RIP2, dendritic cells, adaptive immunity. 
1. Introdução 


\section{1 - Leishmaniose: Características gerais e epidemiologia}

As leishmanioses compreendem um complexo de doenças negligenciadas cujos agentes etiológicos são parasitos intracelulares obrigatórios pertencentes à ordem Kinetoplastida, à família Tripanosomatidae e ao gênero Leishmania (Ross, 1903). A doença acomete mamíferos, incluindo o homem, os quais compreendem os hospedeiros vertebrados e albergam as formas amastigotas do parasito. Os insetos dípteros hematófagos da família Psychodidae, subfamília Phlebotominae, gêneros Phlebotomus e Lutzomyia são os hospedeiros invertebrados, onde podem ser encontradas as formas promastigotas. A infecção do hospedeiro vertebrado ocorre principalmente através do inóculo de formas promastigotas metacíclicas por meio da picada do flebotomíneo fêmea (Peters et al., 1990; Peacock et al., 2007).

O gênero Leishmania abarca cerca de 30 espécies de protozoários heteroxênicos. Elas são divididas em três subgêneros distintos, Viannia, Leishmania e Sauroleishmania (Gardener, 1977), de acordo com o ciclo de vida apresentado no interior do inseto vetor. O subgênero Sauroleishmania inclui apenas os organismos encontrados parasitando répteis (Lainson 1987, Killick-Kendrick, 1986). Infecções em aves e anfíbios não são descritas. Além disso, os parasitos podem ser agrupados em quatro complexos fenotípicos segundo características clínicas, epidemiológicas, de desenvolvimento em animais de laboratório (hamsters), em meio de cultura e características genéticas e isoenzimáticas; são eles: complexo Leishmania braziliensis, Leishmania mexicana, Leishmania tropica e Leishmania donovani. Os parasitos pertencentes ao complexo Leishmania braziliensis (L. braziliensis, L. panamensis, L. guyanensis, e L. peruviana) são encontrados apenas nas Américas (novo mundo) e caracterizam-se pelo parasitismo cutâneo (leishmaniose cutânea - LC) e/ou mucocutâneo (leishmaniose mucocutânea- LM) sem invasão de vísceras. A LC surge como úlceras na pele no local da picada, podendo evoluir e disseminar-se ou não, enquanto que a LM é uma consequência da LC, que pode surgir mesmo anos após a 
cicatrização da primeira úlcera da pele, resultando em uma progressiva ulceração na mucosa nasal e/ou junções mucocutâneas. O complexo Leishmania mexicana inclui as espécies L. mexicana, L.pifanoi e L. amazonensis, essas geram lesões que não atingem a região mucosa, porém podem causar uma forma rara e complicada da LC, chamada de leishmaniose cutânea difusa (LCD). A LCD ocorre como consequência de uma deficiência na resposta imune mediada por células, onde os nódulos cutâneos disseminam-se por toda a região corpórea. Nos países do velho mundo, principalmente na região da Bacia do Mediterrâneo e na Ásia, o complexo Leishmania tropica, o qual inclui as espécies L. tropica, L. major e L. aethiopica, causam lesões restritas à pele (ElHassan et al., 1995; Wilson et al., 2005; Reithinger et al., 2007).

Segundo a Organização Mundial de Saúde (OMS), além das formas cutânea e mucocutânea, existe uma terceira forma clínica, a leishmaniose visceral (LV) (WHO, 2015). A LV, ou calazar, é uma doença sistêmica crônica que pode conduzir $100 \%$ dos pacientes ao óbito em até dois anos se não forem submetidos à terapia específica (WHO, 2015), sendo, portanto, a forma mais grave das leishmanioses.

Os fatores que determinam a gravidade das manifestações clínicas podem estar ligados às condições ambientais (Moreno et al., 2005), à idade (Caldas et al., 2002) ao estado nutricional (Badaro et al., 1986; Bern et al., 2007) e, principalmente, a espécie de Leishmania e a resposta imune do hospedeiro infectado (Gama et al., 2004; Pedrosa e Da Rocha, 2004; Da Silva et al., 2005; Cruz et al., 2006). Curiosamente, a maioria dos indivíduos infectados não apresenta a doença clinicamente manifestada, porém, aproximadamente $20-40 \%$ dos indivíduos apresentam algum tipo de sintoma como: febre irregular e intermitente, perda de peso, esplenomegalia, hepatomegalia, pancitopenia, hipoalbuminemia, hipergamaglobulinemia, linfoadenopatia e anemia. Calcula-se que $20 \%$ dos indivíduos desenvolvem a forma clássica da doença, com estado de debilidade geral, caquexia e óbito (Evans et al., 1992; Badaro et al., 1996; Jeronimo et al., 2000; Silveira et al., 2010). As espécies do complexo Leishmania donovani são responsáveis pela 
LV, o qual inclui as espécies L. donovani e L. infantum (sinônimo: L. chagasi). Essa última é o agente etiológico da LV no Brasil (Mauricio et al., 2000), enquanto que a L. donovani causa LV em países do velho mundo (Wilson et al., 2005). Estima-se que 12 milhões de pessoas estejam infectadas por parasitos do gênero Leishmania em 88 países, dos quais 79 são considerados subdesenvolvidos ou em desenvolvimento. Além disso, existe a estimativa de que 1 milhão e 300 mil novos casos aconteçam por ano, com a ocorrência de 20 a 30 mil mortes anuais em função da infecção por parasitos do gênero Leishmania (WHO, 2015). Ainda, 350 milhões de pessoas no mundo localizam-se em áreas consideradas de risco de infecção (Alvar et al., 2004). Em relação à LV, estima-se que entre 3 e 4 milhões de pessoas estejam infectadas por $L$. donovani ou $L$. infantum no mundo e que ocorram entre 200 a 400 mil novos casos/ano, com mais de 20 mil mortes anuais (WHO, 2012; WHO, 2015). Mais de 90\% dos casos de LV estão concentrados em seis países: Brasil, Bangladesh, Índia, Etiópia, Sudão do Sul e Sudão; e ainda, cerca de 90\% dos casos de LV na América Latina ocorrem no Brasil (WHO, 2015; Desjeux, 2004). Segundo dados do Ministério da Saúde, no Brasil, em 2013, foram confirmados 3.253 casos humanos com 231 óbitos (letalidade de 7,1\%), sendo mantida a média de aproximadamente 3.500 casos anuais da última década contabilizada (2004 a 2013) (SINAN/SVS/MS, 2014).

A leishmaniose é uma doença de grande importância para saúde pública, devido à considerável expansão geográfica e alta taxa de mortalidade, especialmente em crianças mal nutridas, idosos e, principalmente, pacientes portadores de coinfecção Leishmania-HIV (Ezra et al., 2010). A alta incidência das leishmanioses, acompanhada por lesões incapacitantes, desfigurantes (LC e LM) e casos fatais (principalmente na LV), levou a OMS a incluir as leishmanioses entre as seis endemias mais importantes no mundo.

$\mathrm{Na} L V$, após a inoculação das formas promastigotas metacíclicas pelos flebotomíneos na derme, há a multiplicação inicial das formas amastigotas no interior de fagócitos que chegam ao sítio de infecção. Posteriormente, ocorre o processo de visceralização para o baço, fígado, 
linfonodos e medula óssea, principalmente. A partir daí, o curso da relação estabelecida entre parasito e hospedeiro é determinado por uma rede de fatores complexos, os quais incluem os componentes da saliva do inseto vetor, as proteínas de superfície e secretadas pelo parasito e a resposta imunológica desencadeada no hospedeiro. Nesse contexto, respostas de padrões distintos e ainda pouco esclarecidos podem ser geradas.

\section{2 - Eventos iniciais da infecção por Leishmania}

A infecção de mamíferos por parasitos do gênero Leishmania ativa uma rede complexa de mecanismos imunológicos no hospedeiro. Essa resposta é iniciada na derme logo após a inoculação das formas promastigotas metacíclicas juntamente com componentes imunomoduladores da saliva do vetor, quando então múltiplos tipos celulares são quimioatraídos para o sítio de infecção. Acredita-se que o dano tecidual provocado pela picada do flebótomo promova a liberação de alarminas, como interleucina (IL)-33, que seriam responsáveis pelo rápido influxo de neutrófilos para a pele (Haraldsen et al., 2009; Thalhofer et al., 2011). A Leishmania pode sobreviver dentro de vacúolos não leishmanicidas nos neutrófilos nas primeiras horas ou primeiros dias após a infecção (Laufs et al., 2002), quando então ele passa a expressar moléculas apoptóticas e são fagocitados por macrófagos (Van Zandbergen et al., 2004). Quando macrófagos ingerem neutrófilos apoptóticos infectados os mecanismos microbicidas inatos não são ativados (Meagher et al., 1992), significando que o parasito entra no macrófago de maneira silenciosa, fenômeno conhecido como "cavalo de Tróia" (Laskay et al., 2003).

Fagócitos mononucleares são as principais células hospedeiras da Leishmania, e, embora o parasito consiga diferenciar-se em amastigota e proliferar dentro de células dendríticas (Prina et al., 2004), os macrófagos são as células hospedeiras preferenciais, onde os parasitos sobrevivem, proliferam intensamente nos vacúolos parasitóforos e podem propagar-se para diferentes tecidos 
em hospedeiros suscetíveis. Os macrófagos residentes na derme compõem a maior população de células infectadas depois das primeiras 24 horas (Peters et al., 2008). Com a progressão da infecção, monócitos são recrutados do sangue e se diferenciam, principalmente, em células dendríticas (moDCs), as quais aumentam a expressão de MHC de classe II e são fonte importante de IL-12 (Konecny et al., 1999; Leon et al., 2007).

A migração de células infectadas do sítio de infecção inicial para órgãos linfóides secundários é dependente de quimiocinas e seus receptores, mas esse é um evento ainda pouco esclarecido. O receptor de quimiocina CCR7 é importante para migração de células dendríticas maduras dos tecidos para as áreas de células T nos órgãos linfóides secundários (Forster et al., 1999). Lá irá ocorrer a sensibilização dos linfócitos pelas células apresentadoras de antígeno (APCs) (Moll et al., 1993; Prina et al., 2004), dando início à expansão de células T efetoras específicas para o antígeno. A diferenciação linfocitária vai depender, dentre outros fatores, do tipo de APC, das moléculas coestimuladoras expressas na superfície celular e das citocinas que predominam no microambiente nos primeiros momentos da sensibilização.

Os mecanismos discutidos nessa seção estão resumidos e esquematizados na Figura 1. 


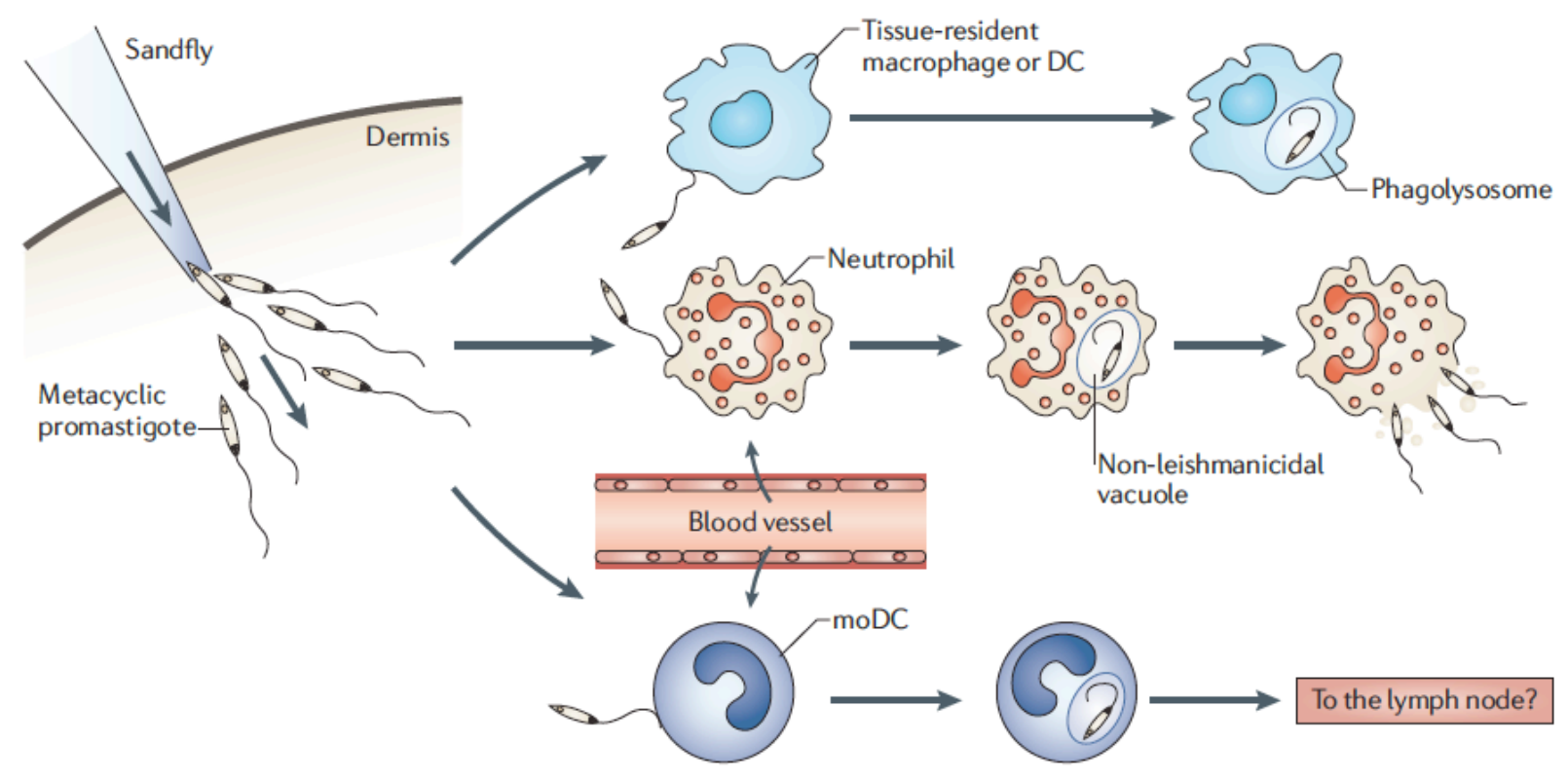

Figura 1: Tipos celulares envolvidos na fagocitose da Leishmania nos momentos iniciais da infecção. Formas promastigotas metacíclicas são inoculadas na derme do hospedeiro juntamente com componentes da saliva do inseto vetor. Macrófagos ou células dendríticas residentes no tecido iniciam o processo de fagocitose. O trauma mecânico da picada do flebótomo pode resultar na liberação de alarminas (como IL-33) que atuam no recrutamento de neutrófilos, os quais englobam os parasitos em vacúolos não leishmanicidas. A replicação do parasito pode levar a morte dos neutrófilos e liberação de mais alarminas (como high mobility group protein B1 (HMGB1) e IL-1 1 ), as quais atraem monócitos inflamatórios para o local da infecção. Células dendríticas monocíticas (moDCs) infectadas podem facilitar o tráfico de parasitos para órgãos linfóides secundários. (Retirado e adaptado de Kaye e Scott, 2011).

\section{3 - Receptores da imunidade inata}

A imunidade inata promove uma resposta inflamatória não específica e generalizada contra infecções ou outras injúrias. Os fagócitos que compõem os eventos iniciais da resposta imune frente à infecção por Leishmania, macrófagos e células dendríticas, em especial, possuem receptores codificados em linhagens germinativas, os quais são encontrados em uma grande variedade de organismos multicelulares e são altamente conservados evolutivamente (revisado em Motta et al., 2015). Esses receptores são capazes de discriminar moléculas próprias e não próprias, pois reconhecem padrões moleculares associados aos patógenos (PAMPs), como ácidos 
nucléicos (motivos $\mathrm{CpG}$ ), componentes da paredes celular de fungos e bactérias, proteínas flagelares, dentre outros. Essas moléculas, portanto, possuem papel indispensável para iniciar a montagem da resposta imunológica contra vírus, bactérias, fungos e protozoários (Janeway e Medzhitov, 2002).

A primeira família de receptores inatos estudada em detalhes foram os receptores do tipo Toll (TLRs) (Medzhitov, 2001). Essa proteína foi identificada inicialmente em Drosophila melanogaster em que, considerando aspectos imunológicos, está envolvida na montagem da resposta imune eficaz contra o fungo Aspergillus fumigatus (Lemaitre et al., 1996). Hoje são descritos 13 e 10 membros da família dos TLRs em camundongos e humanos, respectivamente. Esses receptores são posicionados em regiões transmembrana na superfície da célula, como os TLR1, TLR2, TLR4, TLR5 e TLR6; ou em vesículas endossomais - TLR3, TLR7, TLR8 e TLR9. Eles reconhecem diferencialmente os PAMPs e sinalizam via proteínas que contém domínio TIR, como MyD88 (myeloid differentiation primary response gene 88), TIRAP [TIR-containing adaptor protein, também conhecida como MAL (MyD88-adaptor-like)], TRIF [TIR-containing adaptor-inducing IFN (interferon)- $\beta$ ] e TRAM (TRIF-related adaptor molecule). Essa cascata de

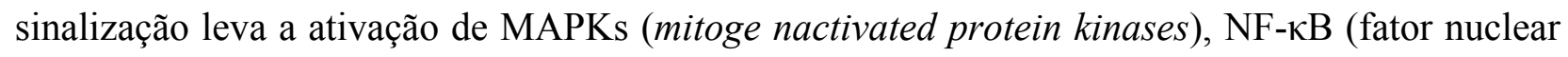
$\kappa B)$ e IRFs (fatores reguladores de interferon), iniciando uma resposta inflamatória.

Além dos TLRs, mais quatro famílias de receptores já foram descritas: retinoic acidinducible gene-I (RIG-I)-like receptors (RLRs), C-type lectins (CTLs), absent-in-melanoma (AIM)-like receptors (ALRs) e os nucleotide-binding leucine-rich repeat-containing receptors (NLRs). Em conjunto, esses receptores promovem uma extensa linha de defesa contra moléculas exógenas e padrões moleculares associados ao dano/perigo (DAMPs) (Shi et al., 2003; Motta et al., 2015).

Os receptores do tipo NOD, pertencentes à família dos NLRs, são proteínas solúveis localizadas no citoplasma celular (Kufer et al., 2005) ou, sob influência de estímulos, também 
podem associar-se à membrana plasmática (Barnich et al., 2005; Kufer et al., 2008) ou à membrana endossomal (Nakamura et al., 2014). Eles sinalizam em resposta a patógenos intracelulares ou antígenos que estejam no meio intracelular. Sendo assim, os NLRs possuem papel na iniciação da resposta contra PAMPs e DAMPs, como componentes da parede celular bacteriana, toxinas, ATP, acúmulo de cristais de ácido úrico ou baixas concentrações de potássio intracelular (Martinon et al., 2002; Shi et al., 2003; Martinon et al., 2004). Em humanos, a família dos NLRs é composta de 23 proteínas, e existem aproximadamente 34 genes NLR descritos em camundongos (Ting et al., 2008). Homólogos dos NLRs também estão presentes em plantas e animais filogeneticamente mais primitivos, como o Zebrafish e ouriços do mar (HIBINO et al., 2006; INOHARA; NUNEZ, 2003). Esses receptores são expressos, principalmente, em células do sistema imune inato, como APCs, mas também em células epiteliais e mesoteliais (Chen et al., 2009).

Os NLRs apresentam uma estrutura característica composta por três domínios distintos: uma região carboxiterminal rica em leucina, denominada LRR, responsável pelo reconhecimento antigênico; um domínio NOD (Nucleotide-binding Oligomerization Domain), responsável pela oligomerização do receptor após a ligação ao ATP e um domínio aminoterminal distinto, o qual desencadeia a função efetora do receptor (Athman e Philpott, 2004). Na ausência de infecção, o NLR encontra-se em uma forma inativa, em que as regiões efetoras permanecem protegidas pela região LRR, bloqueando sua ativação. A ligação de antígenos ao LRR promove uma modificação estrutural no receptor permitindo a ligação de ATP ao domínio NOD, o qual se oligomeriza promovendo a sinalização celular característica de cada NLR (Fig. 2) (Zink et al., 2002).

De acordo com o domínio aminoterminal, os NLRs podem ser divididos em duas subfamílias distintas: 1) a subfamília NLRC é composta por receptores que expressam o domínio de recrutamento de caspase (CARD), e incluem NOD1 (domínio 1 de oligomerização nuclear, também conhecido como domínio 4 de recrutamento de caspase - CARD4), NOD2 (também 
conhecido como CARD15), NLRC4, e também proteínas com domínios ainda não caracterizados (X), como NLRX1, NLRC3 e NLRC5 (Claes et al., 2015). A subfamília 2) é a NLRP, a qual inclui proteínas cuja a porção aminoterminal é constituída de um domínio rico em pirina (PYD) e incluem os 14 NALPs, os quais dependem da molécula adaptadora ASC para induzir a formação do complexo protéico denominado inflamassoma (Meylan et al., 2006; Wilmanski et al., 2008).

Os receptores NOD1 e NOD2, componentes da subfamília NLRC, foram os primeiros NLRs reportados como tendo papel no reconhecimento de PAMPs no meio intracelular (Wilmanski et al., 2008). NOD1 contém um único domínio CARD e é um receptor ubíquo, expresso em uma grande variedade de células e tecidos, enquanto que o NOD2 possui dois domínios CARDs e é expresso somente em células dendríticas, células de Paneth, monócitos e macrófagos (Ogura et al., 2003; Inohara et al., 2005). Os primeiros ligantes descritos para NOD1 e NOD2 foram fragmentos de peptideoglicano (PGN) da parede celular bacteriana, sendo que NOD1 reconhece o ácido $\gamma$-D-glutamil-meso-diaminopimélico (iE-DAP) encontrado em todas as bactérias gram-negativas e algumas gram-positivas, enquanto que NOD2 reconhece muramil dipeptídeo (MDP), componente comum em todas as bactérias gram-positivas e gram-negativas (Shaw et al., 2008). Mais recentemente, outros agonistas de NOD2 tem sido identificados, como por exemplo, N-glicolilmuramil dipeptídeo de micobactéria (Coulombe et al., 2009) e RNA viral de fita simples (Sabbah et al., 2009), demonstrando que esses receptores podem iniciar uma resposta através do reconhecimento de uma variedade de moléculas derivadas de patógenos.

A ativação de NOD1 e NOD2 induz uma cascata de sinalização intracelular através da oligomerização e recrutamento da proteína adaptadora receptor-interacting serine-threonine kinase 2 (RIP2 ou RICK) (Bertin et al., 1999; Ogura et al., 2001). RIP2 também possui um domínio amino-terminal CARD, e a interação CARD-CARD permite a ativação de uma cascata bioquímica (Fig. 2) que induz a ativação de NF-אB e MAPKs (p38, JNK e ERK1/ERK2), promovendo a produção de citocinas proinflamatórias e quimiocinas (Werts et al., 2007; Berube 
et al., 2009; Franchi et al., 2009). Camundongos deficientes de RIP2 são incapazes de ativar NF$\kappa \mathrm{B}$ em resposta a agonistas de NOD1 e NOD2, revelando o papel crucial da proteína adaptadora RIP2 na sinalização desses receptores e demonstrando que a modulação de RIP2 promove mecanismos de regulação da atividade de NOD1 e NOD2 (Kobayashi et al., 2005; Park et al., 2007).

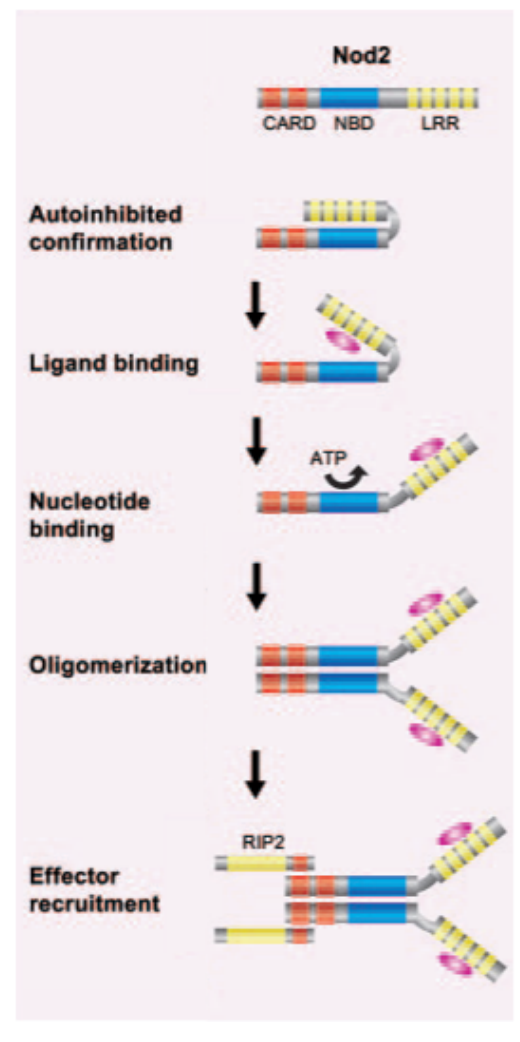

Figura 2: Representação esquemática da sinalização inicial via NOD2. Na ausência do estímulo, NOD2 permanece em uma conformação de auto-inibição. A ligação de moléculas antigênicas (em rosa) ao domínio LRR (em amarelo) altera a conformação do receptor, permitindo o acesso do ATP ao domínio NOD (em azul). Esse evento altera a conformação do receptor, permitindo sua ativação e oligomerização. Há então o recrutamento da molécula adaptadora RIP2 que interage com NOD2 através do domínio CARD (em laranja) e se auto-fosforila. Esse evento inicia e ativa a cascata de sinalização subsequente. Modificado de Wilmanski et al., 2008. 
As funções dos NLRs e TLRs podem ser entendidas como sendo naturalmente díspares, pois eles possuem localização celular distinta. Além disso, a ativação e sinalização dos receptores NLRs ocorrem de maneira independente dos TLRs (Park et al., 2007). Todavia, sob determinadas circunstâncias, essas duas vias podem interagir sinergicamente (Kim et al., 2015). Essa aparente redundância no que diz respeito ao reconhecimento de patógenos pelos NLRs e TLRs potencializa a resposta inflamatória à infecção, como é demonstrado pelo sinergismo entre a sinalização de TLR e NLR em resposta ao PGN (Ferwerda et al., 2005; Netea et al., 2005; Uehara et al., 2005), ou ainda entre agonistas de TLR2, TLR3, TLR4 e NOD2, na produção de IL-6 e IL-12 (Kobayashi et al., 2005). Por outro lado, essa interação também pode ocorrer de forma antagônica, como demonstrado pela capacidade de NOD2 em sentir a alta intensidade da sinalização via TLR4 e então atuar na contração da resposta inflamatória e manutenção do estado de homeostase (Kim et al., 2015).

Consistente com o papel de NOD1 e NOD2 na montagem da resposta imunológica no hospedeiro frente a infecções, camundongos $N o d 1^{-/-}$e $N o d 2^{-/-}$são suscetíveis a infecção por diversos patógenos. NOD1 está envolvido no reconhecimento de patógenos bacterianos intracelulares gram- negativos, como Escherichia colli, Chlamydia spp., Campylobacter jejuni e Salmonella spp. (Kim et al., 2004; Opitz et al., 2005; Welter-Stahl et al., 2006; Zilbauer et al., 2007; Keestra et al., 2011), e também atua na resposta contra Listeria monocytogenes (Boneca et al., 2007), e microrganismos extracelulares como Pseudomonas aeruginosa e Helicobacter pylori (Viala et al., 2004; Travassos et al., 2005). NOD2 tem sido implicado em detectar e mediar resposta contra Streptococcus pneuomoniae (Opitz et al., 2004), Mycobacterium tuberculosis (Ferwerda et al., 2005), L. monocytogenes (Kobayashi et al., 2005), E. Coli, Shigella flexneri, Bacillus subtilis, Staphylococcus aureus (Girardin et al., 2003), Chlamydophila pneumoniae (Shimada et al., 2009), dentre outros. 
Além de sensores bacterianos, NOD1 e NOD2 também possuem papel na resposta contra protozoários. Foi demonstrado que na ausência de NOD1, mas não de NOD2, camundongos infectados com Trypanosoma cruzi (T. cruzi) apresentam alta carga parasitária e mortalidade (Silva et al., 2010). Existem dados controversos sobre o papel de NOD2 durante a infecção por Toxoplasma gondii (T. gondii); em 2009 foi demonstrado que camundongos geneticamente deficientes para NOD2 falham em montar uma resposta adaptativa efetiva contra o $T$. gondii devido a um defeito intrínseco à célula T, o que diminuiu a produção de IL-2 e o acúmulo nuclear do fator de transcrição c-Rel, indicando que NOD2 teria um papel na resistência do hospedeiro contra esse parasito (Shaw et al., 2009). Em contraste com esses dados, dois anos depois foi reportado que NOD2 seria dispensável para a defesa do hospedeiro contra o $T$. gondii, pois os camundongos $\mathrm{Nod}^{2 /-}$ apresentaram carga parasitária, produção de IL-2, ativação, proliferação e diferenciação de linfócitos T em níveis comparáveis aos de camundongos controles WT (Caetano et al., 2011). Considerando que até hoje não foi identificado nenhum agonista de NOD2 no $T$ gondii, é possível que esses resultados discrepantes ocorram devido a diferenças na microbiota das colônias de camundongos usadas nos experimentos (Zamboni e Lima-Junior, 2015). Estudos com Plasmodium berghei ANKA demonstram que o parasito ativa NOD1 e NOD2, mas esses receptores não são requeridos para a resistência do hospedeiro na malária cerebral (Finney et al., 2009). O papel dos NLR nas infecções por Leishmania apenas começou a ser explorado recentemente. Nosso grupo demonstrou que o inflamassoma de NLRP3 é uma importante plataforma da imunidade inata para a restrição da infecção pelas espécies $L$. amazonensis, $L$. braziliensis e L. infantum. A produção de IL-1 $\beta$ mediada pelo inflamassoma foi crucial para a resistência do hospedeiro à infecção, uma vez que sua sinalização via IL-1R/MyD88 foi importante e suficiente para induzir a produção de óxido nítrico (NO) (Lima-Junior et al., 2013).

Até o momento, nada se sabe sobre o papel dos NLRs 'não formadores de inflamassoma' durante as leishmanioses, e, dado a sua importância na indução da reposta inflamatória, essas vias 
podem representar peças importantes para a compreensão da resposta imunológica nessa doença. Além de sensores de patógenos, NOD1 e NOD2 também tem sido implicados na indução de autofagia e regulação da resposta imune adaptativa (Kobayashi et al., 2005; Travassos, Carneiro, Ramjeet, et al., 2010; Moreira e Zamboni, 2012), embora os sinais e as vias moleculares de disparo dessas funções ainda não sejam bem conhecidos.

\section{4 - Imunidade adaptativa na leishmaniose}

Após o reconhecimento de moléculas do parasito por receptores do sistema imune inato presente em macrófagos e células dendríticas, por exemplo, ocorre, dentre outros eventos, a produção e liberação de fatores solúveis responsáveis pela indução da resposta imune adaptativa celular. Uma vez infectado, a geração da resposta imunológica adaptativa adequada é o ponto crucial que distingue se o hospedeiro irá progredir para a doença ou permanecer assintomático.

Durante a infecção, linfócitos de padrões distintos podem ser gerados a partir da estimulação por APCs e sob influência de fatores presentes no microambiente inflamatório, que colaboram significativamente tanto para a diferenciação do linfócito quanto para a plasticidade de células já diferenciadas (Elias et al., 2008; Reynolds et al., 2010). De maneira simplista, além da presença de um agente infeccioso, para ocorrer a diferenciação para células de padrão T helper (Th)1 é necessário a presença de IL-12; para o perfil Th2 é requerida a produção de IL-4; a polarização para Th17 é determinada pelas citocinas IL-6, TGF- $\beta$, IL-23 e IL-1 $\beta$; células T reguladoras ( $\mathrm{T}$ regs) são induzidas apenas por TGF- $\beta$; linfócitos Th9 são diferenciados na presença de IL-4 e TGF- $\beta$. Isso ocorre porque os diferentes padrões de citocinas induzem a expressão dos fatores de transcrição característicos desses padrões nos linfócitos: T-bet (Th1), Gata-3 (Th2), ROR-yt (Th17), FoxP3 (T regs), PU.1 (Th9), os quais são determinantes para a transcrição de genes de citocinas que caracterizam os diferentes subgrupos celulares (revisado em 
O'shea e Paul, 2010). Além da geração de perfis distintos, uma clara inter-conversão entre os padrões pode ocorrer. A citocina TGF- $\beta$, por exemplo, exerce um papel chave na plasticidade de linfócitos já diferenciados, ela pode induzir a produção de IL-9 por células Th17 (Beriou et al., 2010), ou até mesmo levar os linfócitos Th2 a se diferenciarem em Th9 (Chang et al., 2010). Além disso, na presença de IFN do tipo I, células de padrão Th2 podem ser revertidas em Th1 (Hegazy et al., 2010).

Os mecanismos imunológicos que conferem resistência ou suscetibilidade à infecção por Leishmania foram inicialmente caracterizados em modelos experimentais de infecção com $L$. major em camundongos Balb/c, suscetível, e C57BL/6, resistente (Kane e Mosser, 2001; NobenTrauth et al., 2003; Kaye e Scott, 2011). Uma eficiente apresentação antigênica com os coestímulos necessários e produção de IL-12 por células dendríticas infectadas, levam à diferenciação de linfócitos $\mathrm{T} \mathrm{CD}^{+}$naives em Th1, produtores de IFN- $\gamma$ (Alexander e Bryson, 2005). Juntamente com linfócitos $\mathrm{T} \mathrm{CD}^{+}$, as células $\mathrm{NK}$ e as $\mathrm{T} \mathrm{CD}^{+}$também são fontes importantes de IFN- $\gamma$ (Biron e Gazzinelli, 1995; Scharton-Kersten et al., 1995; Belkaid et al., 2002; Awasthi et al., 2004). Esta citocina atua sobre macrófagos infectados, ativando a enzima óxido nítrico sintase induzível (iNOS ou NOS2), com concomitante produção de NO e consequente morte dos parasitos fagocitados. A citocina TNF- $\alpha$ é produzida por macrófagos infectados, linfócitos $\mathrm{T} \mathrm{CD}^{+}$, neutrófilos e outras células, e age em sinergismo com IFN- $\gamma$ aumentando a ativação de iNOS e levando, portanto, a morte do parasito mediada por NO (Liew et al., 1990; Liew et al., 1997; Bogdan et al., 2000). Em contrapartida, o desenvolvimento de uma resposta imune Th2 durante a infecção por L. major, dominada pela produção de IL-4 e IL-10, desencadeia o padrão de suscetibilidade no hospedeiro (Belkaid et al., 2001; Kane e Mosser, 2001; Sacks e Noben-Trauth, 2002).

Na LV, a resposta Th1 também está associada com resistência à doença e morte dos parasitos, uma vez que animais resistentes à infecção experimental por $L$. donovani produzem 
grande quantidade de IFN- $\gamma$ na fase inicial da infecção e são capazes de manter essa produção alta em fases mais tardias. Também, em indivíduos infectados, mas protegidos contra o desenvolvimento da doença (assintomáticos), altos níveis de IL-2, IL-12 e IFN- $\gamma$ são produzidos por células mononucleares de sangue periférico (PBMC), e uma potente hipersensibilidade do tipo tardia (DTH) pode ser detectada pelo teste de Montenegro (Carvalho et al., 1985; Carvalho et al., 1989). Assim como acontece contra os parasitos causadores de LC, a ativação de macrófagos com IFN- $\gamma$ e TNF- $\alpha$ leva à morte dos parasitos das espécies $L$. donovani e L. infantum (Pearson e Steigbigel, 1981; Murray et al., 1983). Além disso, dados do nosso grupo mostram que a IL-17A produzida durante a infecção por $L$. infantum atua sinergicamente com IFN- $\gamma$ potencializando a produção de NO por macrófagos infectados e aumentando a capacidade leishmanicida dessas células. A ausência de IL-17RA torna os animais mais suscetíveis à LV por L. infantum, uma vez que eles apresentam maiores cargas parasitárias tanto no baço quanto no fígado no curso de 8 semanas de infecção. Ainda, maior quantidade de células T reguladoras produzindo IL-10 e menos linfócitos Th1 foram encontrados nos órgãos alvos da infecção por L. infantum em animais $1 l 17 \mathrm{ra}^{-/-}$comparados com camundongos WT (Nascimento et al., 2015). Todavia, o papel da IL17A na infecção por L. donovani é controverso, uma vez que indivíduos assintomáticos são capazes de produzir altas quantidades de IL-17A e IL-22, enquanto que os pacientes falham em produzir essas citocinas, evidenciando uma relação positiva entre o desenvolvimento do padrão inflamatório Th17 e a proteção contra LV humana (Pitta et al., 2009). Por outro lado, em modelo experimental de infecção por $L$. donovani a IL-17A produzida por células $T \gamma \delta$ e Th17 foi relacionada com suscetibilidade à LV (Sheel et al., 2015; Terrazas et al., 2015). O que existe bem estabelecido na literatura é que o padrão de suscetibilidade à LV por ambos $L$. infantum ou $L$. donovani é caracterizado pela ausência de resposta DTH, baixa linfoproliferação e incapacidade de produção de IL-2 e IFN- $\gamma$ por PBMC em resposta ao antígeno do parasito (Carvalho et al., 1985; Sacks et al., 1987). Ademais, uma elevada produção de citocinas do padrão Th2, como IL-4 
IL-13 e IL-10, está relacionada com suscetibilidade e o desenvolvimento de LV em humanos (Babaloo et al., 2001; Thakur et al., 2003).

A iniciação e manutenção de células T efetoras para combater a infecção por Leishmania de maneira eficiente envolve a ação finamente regulada de populações celulares dos sistemas imunes inato e adaptativo, sendo essa cooperação crucial para a defesa do hospedeiro. As células dendríticas agem como as mais eficientes das APCs uma vez que possuem a maquinaria celular especializada para a apresentação antigênica e ativação da célula T (Rossi e Young, 2005). A descoberta de fatores de transcrição particulares que definem a ontogenia de linhagens de células dendríticas e monócitos tem permitido distinguir tanto essas duas populações, quanto os subtipos de células dendríticas entre si (Satpathy et al., 2012; Guilliams et al., 2014). Nos tecidos linfóides de camundongos, as células dendríticas são categorizadas em 3 grupos, as células dendríticas plasmocitóides (pDC); células dendríticas derivadas de monócitos, como as produtoras de TNF$\alpha /$ iNOS (TIP)-DCs; e as células dendríticas clássicas ou convencionais (cDCs) (Satpathy et al., 2012). Existem poucas evidências de que pDCs ou TIP-DCs são requeridas para iniciar a resposta de células T (Serbina et al., 2003; Sapoznikov et al., 2007; Segura e Amigorena, 2013). O grupo das cDCs contém as populações $\mathrm{CD} 8 \alpha \alpha^{+} \mathrm{CD} 4^{-} \mathrm{CD} 11 \mathrm{~b}^{-}\left(\mathrm{CD} 8 \alpha \alpha^{+} \mathrm{DC}\right), \mathrm{CD}^{-} \mathrm{CD} 4^{+} \mathrm{CD} 11 \mathrm{~b}^{+}$ $\left(\mathrm{CD} 4^{+} \mathrm{CD} 11 \mathrm{~b}^{+} \mathrm{DC}\right)$ e $\mathrm{CD}^{-} \mathrm{CD}^{-} \mathrm{CD} 11 \mathrm{~b}^{+}$(Shortman e Naik, 2007). O subgrupo $\mathrm{CD} 4^{+} \mathrm{CD} 11 \mathrm{~b}^{+}$é dependente do fator de transcrição IRF4, e também expressa 33D1 e SIRP $\alpha$ (células dendríticas mielóides) (Suzuki et al., 2004). Já as CD8 $\alpha \alpha^{+}$são dependentes dos fatores Basic leucin zipper transcription factor, ATF-like 3 (Batf3) e IRF8, e expressam XCR1, DEC205 ou CD103 (Schiavoni et al., 2002; Aliberti et al., 2003; Hildner et al., 2008). Alguns trabalhos vem associando determinadas subpopulações de células dendríticas com a polarização de subtipos distintos de linfócitos T. As células dendríticas $\mathrm{CD} 8 \alpha \alpha^{+} \mathrm{XCR}^{+}$são especializadas em apresentação cruzada de antígenos fagocitados, e, além disso, compõem a principal fonte de IL-12 durante a infecção por L. major, sendo uma população crítica para indução de células Th1, mas 
dispensável para Th2 e Th17 (Ashok et al., 2014; Martinez-Lopez et al., 2015). Por outro lado, as células dendríticas $\mathrm{CD}^{+} 33 \mathrm{D} 1^{+}$estão envolvidas com a polarização de linfócitos Th17 (Persson et al., 2013; Schlitzer et al., 2013).

Sabendo que a imunidade contra a LV causada por L. infantum é dependente de células produtoras de IFN- $\gamma$ e IL-17A, nós investigamos como a diferenciação dos perfis Th1 e Th17 é modulado após a infecção por esse parasito em modelo experimental em camundongos e em grupos de pacientes antes e após o tratamento, comparados com indivíduos assintomáticos e controles saudáveis. A hipótese do nosso trabalho baseia-se no fato de que elementos da imunidade inata desempenham papel crucial e muitas vezes decisivo no destino da imunidade adaptativa. Ambas as subpopulações de células dendríticas clássicas expressam NOD2 e RIP2, e nós acreditamos que essa via poderia ser ativada por componentes da infecção, fazendo com que a resposta imune celular adaptativa seja direcionada a um (ns) perfil (is) de diferenciação de linfócitos $\mathrm{T}$, em detrimento de outro (s), influenciando de maneira decisiva o desfecho do quadro da infecção e/ou doença. De fato, já existem trabalhos na literatura que demonstram a importância desses receptores para indução da resposta imune adaptativa (Krishnaswamy et al., 2013; Liu et al., 2013). Animais deficientes em RIP2 infectados com L. monocytogenes apresentam diminuição dos níveis de IL-12 e, consequentemente, deficiência na produção de IFN- $\gamma$ por células Th1 e NK (56). Além disso, NOD1 possui papel crítico em desencadear respostas dos perfis Th1, Th17 e Th2 durante infecção por H. pylori (Fritz et al., 2007), e NOD2 participa diretamente na geração da resposta de perfil Th1 durante infecção por T. gondii (Shaw et al., 2009). O esclarecimento do papel da via de NOD2-RIP2 em reconhecer produtos da infecção por L. infantum, bem como as células envolvidas e os fatores que são determinantes ou que modulam a diferenciação de linfócitos Th1 e Th17 durante a LV proporcionará uma compreensão ampla dos eventos imunológicos que ocorrem após a infecção por L. infantum, sendo essa a proposta central do nosso trabalho. 
11. Objetivo 


\section{1) Objetivo geral:}

Determinar o papel da via de sinalização de NOD2-RIP2 na geração e/ou modulação da resposta imune adaptativa celular protetora durante a infecção experimental por L. infantum.

\section{2) Objetivos específicos:}

A - Determinar a fonte celular de IL-17A durante na LV;

B - Avaliar a importância das moléculas NOD2 e RIP2 para a geração de células Th1 e Th17;

C - Definir o papel do receptor NOD2 e da sua molécula adaptadora RIP2 no padrão de resistência/suscetibilidade do hospedeiro e na patogênese da infecção por L. infantum;

D - Examinar se as moléculas NOD2 e RIP2 exercem efeito intrínseco ou extrínseco na indução/ativação dos linfócitos Th1 e Th17;

E - Investigar a subpopulação de célula dendrítica responsável pela indução da resposta imunológica adaptativa celular protetora durante a infecção por L. infantum. 
III. Pacientes, Animais, Material \& Métodos 


\section{1 - Pacientes, indivíduos assintomáticos, sujeitos controles e RNAseq}

Os indivíduos envolvidos no estudo são residentes no estado de Sergipe, área endêmica para LV causada por L. infantum. A seleção de pacientes, bem como a coleta das amostras de sangue foram realizadas pelos colaboradores, Dr. Roque Pacheco de Almeida e Dr ${ }^{\mathrm{a}}$. Amélia Maria de Jesus, ambos docentes do Departamento de Medicina do Hospital Universitário da Universidade Federal de Sergipe. Para todos os indivíduos arrolados no estudo, ou para os responsáveis, foi aplicado o Termo de Consentimento Livre e Esclarecido antes do início das coletas das amostras. $\mathrm{O}$ estudo foi aprovado pelo comitê de ética, anexado à Plataforma Brasil (Anexo I). No total, 24 indivíduos foram incluídos no estudo e divididos em quatro grupos: indivíduos sintomáticos, que apresentavam a forma ativa da doença (G1); os mesmos pacientes do G1 depois de serem submetidos ao tratamento por 180 dias compuseram o G2; indivíduos assintomáticos/resistentes (Montenegro positivo porém, ausência de sintomatologia, G3) e indivíduos saudáveis/controle (G4) (Tabela I).

Tabela I: Pacientes e sujeitos controles envolvidos no estudo.

\begin{tabular}{cccccc}
\hline Grupo & No & M & F & $\begin{array}{c}\text { Idade em anos } \\
\text { (Média } \pm \text { DP) }\end{array}$ & Tratamento \\
\hline G1: LV & 6 & 3 & 3 & $16,8 \pm 11$ & Ambisome e/ou Glucantime \\
G2: Tratados & 6 & 3 & 3 & $16,8 \pm 11$ & - \\
G3: Assintomáticos & 7 & 4 & 3 & $15,5 \pm 12,6$ & - \\
G4: Controles & 5 & 5 & - & $23,0 \pm 6,3$ & \\
\hline
\end{tabular}

LV: leishmaniose visceral; M: masculino; F: feminino; DP: desvio padrão. 
As amostras de sangue dos indivíduos incluídos no estudo foram coletadas com seringas estéreis e descartáveis, a vácuo, em tubos PAXgene Blood RNA (PreAnalytix, Suíça). A extração de RNA de sangue total (amostras de 2,5 mL) foi realizado com o kit da mesma linha de produtos, seguindo as instruções do fabricante. O RNA depletado de rRNA e enriquecido de RNA mensageiros codificadores foram utilizados para a construção de bibliotecas de cDNA com o TruSeq ${ }^{\mathrm{TM}}$ Stranded RNA kit e sequenciadas na plataforma de sequenciamento Illumina HiSeq 2500. Todos os procedimentos foram realizados conforme as instruções do fabricante (Illumina, San Diego, CA). Os dados brutos do sequenciamento de cada biblioteca contidos nos arquivos .fastq foram processados para a análise qualitativa por meio dos programa FastQC (http://www.bioinformatics.babraham.ac.uk/projects/fastqc/) e Trimmomatic (Bolger et al., 2014). Os arquivos .fastq filtrados de sequências de baixa qualidade foram então submetidos à etapa de mapeamento das reads no genoma humano (versão GRCh37, Ensembl) por meio do programa TopHat2 (Kim et al., 2013). A quantificação das reads mapeadas foi realizada com o programa HTSeq (http://www-huber.embl.de/users/anders/HTSeq/doc/overview.html.), cujos arquivos de saída contendo a contagem das reads mapeadas em cada gene foram usados como arquivos de entrada no pacote edgeR (Robinson et al., 2010) para cálculo da expressão gênica diferencial. O heatmap foi criado através da plataforma MeV (Multi Experiment Viewer) (Saeed et al., 2003).

\section{2 - Animais}

Camundongos C57BL/6 WT e C57BL/6 deficientes para as moléculas NOD2, RIP2 e BATF3 foram usados nos experimentos. Todos os animais utilizados tinham idades entre 7 e 10 semanas, pesando de 18 a 22 g. Os camundongos WT foram obtidos no Serviço de Biotério 
Central da USP de Ribeirão Preto; os animais $N o d 2^{-/-}$e Rip $2^{-/-}$foram adquiridos do biotério do Centro de Criação de Camundongos Especiais dessa mesma universidade. Eles ficaram no biotério dos departamentos de Imunologia e Bioquímica e Biologia Celular e Molecular e Bioagentes Patogênicos da Faculdade de Medicina de Ribeirão Preto - USP. Para os experimentos realizados na Universidade de Yale, os animais foram mantidos no Yale Animal Resources Center (YARC) facility. Em ambos os biotérios os animais foram mantidos em gaiolas, em um ambiente com temperatura controlada $\left(22\right.$ a $\left.25^{\circ} \mathrm{C}\right)$ e receberam água e ração $a d$ libitum. Os experimentos foram conduzidos de acordo com o Comitê de Ética da Faculdade de Medicina de Ribeirão Preto, da Universidade de São Paulo, SP, processo nº 076/2012 (Anexo II).

\section{3 - Parasitos e infecção experimental}

Formas promastigotas do isolado HU-USF 14 de L. infantum foram mantidas a $25^{\circ} \mathrm{C} \mathrm{em}$ meio Schneider (Sigma-Co, Saint Louis, EUA) suplementado com soro bovino fetal a $20 \%$ (Cultilab, Campinas, SP - Brasil), 2\% de urina masculina humana e 5\% de penicilina e estreptomicina (Sigma-Co). Os parasitos foram cultivados em garrafas de cultura estéreis (Corning Incorporated, Corning, NY-EUA) e passadas em hamsters ou camundongos Balb/c para manutenção da virulência. A infecção experimental foi feita através da veia do plexo orbital com $10^{7}$ formas promastigotas em fase estacionária de crescimento de L. infantum, obtidas após 5 dias de cultura iniciada com $10^{5}$ parasitos $/ \mathrm{mL}$ em $6 \mathrm{~mL}$. 


\section{$3.4-P C R$ array}

Após 0, 4 e 6 semanas de infecção em camundongos WT, fragmentos do fígado foram coletados e armazenados em QIAzol ${ }^{\circledR}$ (QIAGEN Sciences, Maryand, EUA). Para extração do RNA foi utilizado o RNeasy Microarray Tisse Mini Kit (QIAGEN), seguindo as recomendações do fabricante. Após extração, o RNA foi quantificado em espectrofotômetro Nanodrop 2000 (Thermo Fisher Scientific) e a integridade foi analisada por meio de eletroforese capilar em chip com o instrumento 2100 Bioanalyzer (Agilent, Palo Alto, CA, EUA). O DNA complementar (cDNA) foi gerado com o RT2 First Strand Kit (QIAGEN) de acordo com as recomendações do fabricante. Para a detecção das variações nos transcritos foi utilizado o $R T^{2}$ Profiler $^{T M} P C R$ Array Mouse Innate \& Adaptative Immune Responses (QIAGEN) de acordo com a recomendação do fabricante. A análise de dados foi feita em plataformas on line disponíveis em http://pcrdataanalysis.sabiosciences.com/pcr/arrayanalysis.php http://bioinfo.genotoul.fr/index.php?id=116.

\section{5 - Diferenciação de células dendríticas e infecção in vitro}

As células dendríticas foram obtidas a partir de precursores da medula óssea (BMDC) de fêmures e tíbias de camundongos naives. As epífises foram seccionadas em ambiente estéril e as medulas lavadas com meio de cultura RPMI incompleto utilizando uma seringa com agulha $13 \mathrm{x}$ $4,5 \mathrm{~mm}$. As células recém-colhidas foram centrifugadas a $350 \mathrm{x} \mathrm{g}$ por 10 minutos a $4^{\circ} \mathrm{C}$, eliminando-se o sobrenadante e incubando o sedimento com tampão de lise ACK por 4 minutos à temperatura ambiente. As células foram submetidas a um novo ciclo de centrifugação e, em seguida, diluídas em RPMI suplementado com 10\% de soro fetal bovino (Cultilab), 1\% de estreptomicina e penicilina (Sigma-Co) e 20 ng/mL de GM-CSF (PeproTech Inc., Rocky Hill- 
EUA) na concentração de $2 \times 10^{5}$ células/mL. Dois milhões de células foram distribuídas em placas de tamanho $100 \times 15$ mm não tratadas para aderência (Corning) e mantidas em cultura em estufa a $37^{\circ} \mathrm{C}$ e $5 \%$ de $\mathrm{CO}_{2}$ por sete dias. No dia 3 foi adicionado $10 \mathrm{~mL}$ de meio de diferenciação, e no dia 6 foi retirado $10 \mathrm{~mL}$ de meio e adicionado mais $10 \mathrm{~mL}$ de meio de diferenciação novo. $5 \times 10^{5}$ células foram plaqueadas em $1 \mathrm{~mL}$ de meio em placas de 24 poços tratadas para aderência e as infecções in vitro foram feitas na proporção de 5 ou 10 parasitos em fase estacionária de crescimento para cada célula. O estímulo com MDP (10 $\mu \mathrm{g} / \mathrm{mL}$; Sigma) foi feito através da transfecção da célula com Lipofectamina 2000 (Invitrogen) de acordo com as recomendações do fabricante.

\section{6 - Extração de RNA e síntese do cDNA}

O RNA total foi extraído das culturas de BMDCs e de tecidos de camundongos infectados e de controles naives. O método de extração combinou a utilização do reagente TRIzol (Invitrogen Corporation-Carlsbad, USA) seguida pela utilização parcial do kit de extração Illustra RNAspin Mini (GE Healthcare, Alemanha). Resumidamente, as células ou tecidos ( $50 \mathrm{mg})$ foram armazenados em $500 \mu \mathrm{L}$ de TRIzol a $-70^{\circ} \mathrm{C}$ até o momento da extração, quando então as amostras foram descongeladas no gelo e trituradas, caso necessário, com auxílio de haste homogeneizadora livre de RNAse. Foi adicionado $200 \mu \mathrm{L}$ de clorofórmio e a solução foi agitada durante 15 segundos e centrifugada a 10000 x g por 10 minutos a $4^{\circ} \mathrm{C}$. A porção aquosa superior foi coletada e utilizada para extração com o kit supracitado de acordo com as recomendações do fabricante. Após extração, a qualidade do RNA foi checada em gel de agarose $1 \%$ corado com brometo de etídeo, e quantificado em NanoDrop ${ }^{\mathrm{TM}} 2000$ (Thermo Fisher Scientific, EUA). Para a síntese do cDNA, $2 \mu \mathrm{g}$ de RNA foi adicionado a $1 \mu \mathrm{L}$ de Oligo dT $(500 \mu \mathrm{g} / \mathrm{mL})$ em volume final de $13 \mu \mathrm{L}$, completados com $\mathrm{H}_{2} \mathrm{O}$ estéril e livre de nucleases. 
As amostras foram incubadas a $70^{\circ} \mathrm{C}$ por 3 minutos em termociclador PTC-100 (MJ Research, Watertown, EUA) seguido por uma incubação no gelo por 1 minuto. À reação foi adicionado um mix contendo $4 \mu \mathrm{L}$ de tampão da enzima, $2 \mu \mathrm{L}$ de DTT, $2 \mu \mathrm{L}$ de dNTP $10 \mathrm{mM}$ e $0,5 \mu \mathrm{L}$ da enzima transcriptase reversa SMART MMLV (Clontech Laboratories, Inc., Mountain View, CA, EUA). A reação foi incubada a $42^{\circ} \mathrm{C}$ por 60 minutos e depois a $10^{\circ} \mathrm{C}$ por 15 minutos. $\mathrm{O}$ cDNA foi diluído 10 vezes em água estéril e livre de nucleases e armazenado a $-20^{\circ} \mathrm{C}$ até o momento do uso.

\section{7 - PCR em tempo real-qPCR}

A quantificação relativa de transcritos de genes alvos foi realizada por PCR em tempo real. A reação foi realizada com $6,5 \mu \mathrm{L}$ de SYBR Green Mix (Invitrogen), 0,5 $\mu \mathrm{L}$ de cada primer (senso e antisenso) a $10 \mu \mathrm{M}, 5 \mu \mathrm{L}$ do cDNA e água estéril e livre de nucleases suficiente para completar o volume final para $15 \mu \mathrm{L}$. As reações foram realizadas em aparelho StepOnePlus ${ }^{\mathrm{TM}}$ Real-Time PCR Systems (Applied Biosystems, EUA), sendo o ciclo iniciado a $50^{\circ} \mathrm{C}$ por 2 minutos, $95^{\circ} \mathrm{C}$ por mais 2 minutos e 40 ciclos de 15 segundos a $95^{\circ} \mathrm{C}, 30$ segundos a $58^{\circ} \mathrm{C}, 30$ segundos a $72^{\circ} \mathrm{C}$. Um ciclo final de 20 minutos com temperatura crescente de 60 a $95^{\circ} \mathrm{C}$ foi empregado para obtenção da curva de dissociação dos produtos da reação, utilizada para análise da especificidade da amplificação. Todas as reações foram feitas em duplicatas, os resultados normalizados com o Hprt (Hypoxanthine-guanine phosphoribosyltransferase) constitutivamente expresso e analisados com base no valor de $\mathrm{Ct}$ (cicle threshold) ou linha de corte. O resultado foi calculado com a fórmula $\Delta \Delta \mathrm{Ct}=\Delta \mathrm{Ct}$ da amostra teste $-\Delta \mathrm{Ct}$ da amostra controle, onde $\Delta \mathrm{Ct}=\mathrm{Ct}$ do gene estudado - Ct do Hprt (gene constitutivamente expresso, utilizado como controle interno da reação). O número de vezes de expressão diferencial do RNA mensageiro comparado com o 
controle foi definido pela fórmula $2^{-\Delta \Delta \mathrm{Ct}}$. Os primers e sequências utilizados para as reações de PCR em tempo real estão listados na Tabela II.

Tabela II: Sequência dos primers utilizados nas reações de PCR em tempo real.

\section{SEQUÊNCIAS}

\begin{tabular}{|c|c|c|}
\hline Gene & Senso & Antisenso \\
\hline Hprt & TGGAAAAGCCAAATACAAAGC & CAACATCAACAGGACTCCTCG \\
\hline Il6 & TTCCTACCCCAATTTCCAAT & CCTTCTGTGACTCCAGCTTATC \\
\hline Il23p19 & AATGTGCCCCGTATCCAGTGT & GGCTCCCCTTTGAAGATGTCA \\
\hline$I l 1 b$ & ATGGGCTGGACTGTTTCTAATG & ATTCACGAAAAGGGAGCTCC \\
\hline $1117 a$ & TGCCCTCCACAATGAAAAGA & AACACGAAGCAGTTTGGGAC \\
\hline Nod 2 & CGACATCTCCCACAGAGTTGTAATCC & GGCACCTGAAGTTGACATTTTGC \\
\hline Rip2 & TCATCGAGGTCTCATGATCTCTCT & AGCATTTCAAAAAGGATGGTCTT] \\
\hline$T g f b$ & ACCGCAACAACGCCATCTAT & TCAAAAGACAGCCACTCAGGC \\
\hline$I 112 p 35$ & CTGCTGAAATCTTCTCACCGT & AAGGGTGGCCAAAAAGAGGAG \\
\hline$I l 12 / 23 p 40$ & GTTCGAATCCAGCGCAAGAA & GACATTCCCGCCTTTGCATT \\
\hline
\end{tabular}

\section{8 - Microscopia confocal}

Células dendríticas foram plaqueadas sobre lamínulas circulares estéreis de $12 \mathrm{~mm}$ tratadas com poli-L-Lisina (BioCoat, BD Biosciences, San Diego, CA, EUA) em placas de 24 poços (Corning) na concentração de $2 \times 10^{5}$ células por poço em $300 \mathrm{uL}$ de RPMI 10\%. As células foram infectadas ( 5 parasitos/célula) e após 24 h foram fixadas com paraformaldeído 2\% por 10 minutos a temperatura ambiente, e então lavadas duas vezes com PBS por 5 minutos cada. A permeabilização celular foi feita com Triton X-100 0,5\% por 10 minutos a temperatura ambiente, depois disso mais dois ciclos de lavagem de 5 minutos foram realizados com PBS. O bloqueio foi feito com 1\% de BSA e 10\% de soro de rato (Stemcell Technologies, Vancouver, 
BC, Canadá) diluídos em PBS, por $1 \mathrm{~h}$ a temperatura ambiente. $\mathrm{O}$ anticorpo primário coelho anti-NOD2 (H-300) (Santa Cruz Biotechnology, Inc. Texas-EUA) foi diluído em PBS/BSA 1\% (1:300) e incubado $16 \mathrm{~h} \mathrm{a} 4^{\circ} \mathrm{C}$; após esse período, as células foram lavadas 3 vezes por 10 minutos com PBS/BSA 1\%. O anticorpo secundário utilizado foi anti-coelho conjugado a Alexa flúor 488 (Invitrogen), incubado por mais 1 hora a temperatura ambiente. Após 3 lavagens com PBS/BSA 1\%, as lâminas foram montadas em Prolong contendo DAPI (Cell Signalling Technology, Danvers, MA, EUA) e fotografadas em microscópio confocal Leica SP5 (Leica Microsystems, Heerbrugg, Suíça) no aumento da objetiva de 100 X. As imagens foram analisadas no Leica QWin Quantitative Imaging software e Adobe Photoshop (Adobe Systems Incorporated). Os resultados estão expressos em intensidade de fluorescência.

\section{9- Imunofluorescência}

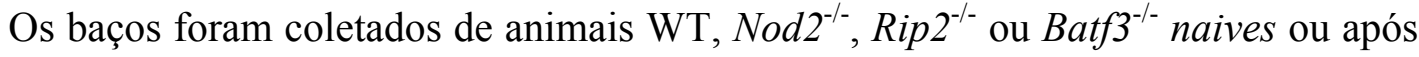
6 horas de infecção, quando ocorre o pico de migração de células dendríticas da polpa vermelha para a polpa branca. Os órgãos foram submetidos a uma bateria de desidratação com níveis crescente de solução de glicose $(10 \%, 20 \%$ e $30 \%)$ por $1 \mathrm{~h}$ em cada solução. Posteriormente, o tecido foi incluído em Tissue-Tek ${ }^{\circledR}$ O.C.T. Compound (Sakura ${ }^{\circledR}$ Finetek, Sakura, Torrance, CA), congelado e seccionado em seções de $7 \mu \mathrm{m}$. As lâminas contendo os tecidos foram incubadas 20 minutos em PBS e então bloqueadas por mais 20 min com 10\% de soro de rato (Stemcell Technologies) em solução de PBS contendo 1\% de BSA e 0,1\% de Tween 20 (Sigma) (solução de lavagem). Os anticorpos primários 33D1 (biotinilado, 1:300; clone 33D1), XCR1 (biotinilado, 1:900; clone ZET), CD11c (BV421, 1:25; clone N418), TCR $\beta$ (Alexa flúor 647, 1:100; clone H57-597) (BioLegend) e NOD2 (não conjugado, 1:300; clone P18) (Santa Cruz) foram incubados por $1 \mathrm{~h}$ a temperatura 
ambiente. Antes de adicionar os anticorpos secundários, anti-cabra IgG conjugado a FITC, 1:300 (Santa Cruz) ou streptavidina-PE, 1:1000 (BioLegend), os tecidos foram lavados 3 vezes com solução de lavagem por 10 minutos. Os anticorpos secundários foram incubados por mais $1 \mathrm{~h}$, quando então seguiu-se mais uma bateria de lavagem. As lâminas foram montadas com Prolong (Cell Signalling Technology) e as imagens foram adquiridas em 3 ou 4 cores usando a objetiva de $4 \mathrm{X}$ ou 20X em microscópio de fluorescência Nikon eclipse Ti (Nikon, Tóquio, Japão). Os resultados são expressos em intensidade de fluorescência.

\subsection{0 - Carga parasitária}

Para estudar o padrão de resistência/susceptibilidade dos camundongos dos diferentes grupos frente a infecção por L. infantum, os animais foram sacrificados após 4 e/ou 6 semanas de infecção. O fígado e o baço de camundongos WT e knockouts foram removidos, pesados e a porção inferior do baço e o maior lóbulo do fígado, após pesados, foram macerados em PBS 1X estéril, pH 7,2. $\mathrm{O}$ macerado foi centrifugado a $700 \mathrm{x} \mathrm{g}, 25^{\circ} \mathrm{C}, 10$ minutos e ressuspenso para um volume final de $1 \mathrm{~mL}$ em Schneider 20\%. Posteriormente, as diluições seriadas foram feitas em placas estéreis de 96 poços (Corning Incorporated,), conforme a técnica de diluição limitante descrita previamente na literatura (Titus et al., 1985). As contagens dos poços positivos foram realizadas nos dias 10 e confirmados no dia 14 após a diluição limitante, e o número de parasitos foi estimado como descrito por Buffet et al., 1995 (Buffet et al., 1995). 


\subsection{1 - Dosagem de citocinas por ELISA}

Depois de 7 dias de diferenciação, as BMDCs foram cultivadas na concentração de $5 \times 10^{5}$ células/poço em $400 \mu \mathrm{L}$ de RPMI $10 \%$ em placa de 24 poços. Após 24 h de infecção (5 parasitos: 1 célula) o sobrenadante foi coletado para dosagem das citocinas IL-12/23p40 e IL12p70 e IL-23. Para isso foi realizado o ensaio imunoenzimático (ELISA) do tipo "sandwich”, utilizando-se o kit comercial OpTEIA, (BD Biosciences, San Diego, CA, EUA), seguindo as recomendações do fabricante. Sobrenadante de células sem estímulos foram utilizadas como controles negativos, ou estimuladas com LPS (200 ng/mL) para controles positivos.

\subsection{2 - Cultura de células do baço e do fígado}

Para isolamento das células do baço, após remoção, o órgão foi macerado em condições estéreis, com PBS 1X pH 7,2 e filtrado em cell strainer de 70 uM (BD Biosciences) para obtenção de uma solução de células únicas (single cell suspension). As células obtidas foram centrifugadas a $350 \mathrm{x}$ g durante $10 \mathrm{~min}$ a $4^{\circ} \mathrm{C}$ e posteriormente incubadas com tampão de lise de hemácias ACK a temperatura ambiente durante 4 minutos. As células foram lavadas e ressuspensas em RPMI 5\%. A quantificação e análise de viabilidade celular foram feitas com Azul de Trypan em Câmara de Neubauer. Para isolamento das células do fígado, o órgão teve a vesícula biliar retirada, e foi cortado em fragmentos pequenos para incubação com colagenase do tipo IV (100 U/mL) (Invitrogen ${ }^{\mathrm{TM}}$ | Life Technologies, Carlsbad, EUA) por 45 minutos, à $37^{\circ} \mathrm{C}$, sob agitação. A reação da enzima foi bloqueada com soro bovino fetal. O fígado foi filtrado com cell strainer, centrifugado a $350 \mathrm{x} \mathrm{g}, 10 \mathrm{~min}, 25^{\circ} \mathrm{C}$, e ressuspenso em solução de Percoll 40\% (GE Healthcare Life Sciences, Pittsburgh - EUA). A separação dos gradientes foi feita durante a centrifugação a 500 x g, 25 minutos, $25^{\circ} \mathrm{C}$. Após a coleta das células e lise das 
hemácias, os linfócitos foram quantificados em Câmara de Neubauer diluídos em azul de Trypan. As células do baço e do fígado foram plaqueadas em microplacas de 48 poços (Corning) na densidade de $2,5 \times 10^{6}$ células viáveis/poço em um volume final de $500 \mu \mathrm{L}$. As células foram mantidas por $4 \mathrm{~h}$ sob estímulo com PMA (50 ng/mL), ionomicina (500 ng/mL) e Golgi Stop (BD Bioscience) em estufa com $5 \%$ de $\mathrm{CO}_{2}$ a $37^{\circ} \mathrm{C}$. Após esse período, as células foram analisadas por citometria de fluxo.

\subsection{3 - Citometria de fluxo}

BMDCs, células do baço e do fígado de camundongos foram analisadas por citometria de fluxo. As células foram coletadas e incubadas com tampão de bloqueio (soro de coelho a 10\% diluído em PBS) por 30 minutos a $4^{\circ} \mathrm{C}$ e, em seguida, foram adicionados os anticorpos monoclonais específicos para as moléculas de superfície. As células foram incubadas por 30 minutos, a $4^{\circ} \mathrm{C}$ ao abrigo da luz, e então lavadas 1 vez com PBS antes do início do processo de fixação e permeabilização, quando necessário. Antes dos processos de permeabilização e fixação, as células foram incubadas 15 min a temperatura ambiente com a sonda live/dead (Invitrogen). Após isso, as células foram lavadas 1 vez e então incubadas com Cytofix/Cytoperm (BD Bioesciences, San Diego, CA, EUA) por 20 minutos a $4^{\circ} \mathrm{C}$, lavadas em Perm/Wash 1X (BD Bioesciences) e incubadas 30 minutos a $4^{\circ} \mathrm{C}$ com os anticorpos para marcações intracelulares. Após incubação, as células foram lavadas 2 vezes com Perm/Wash 1X e então adquiridas no aparelho FACSCanto II (BD Biosciences) ou MACSQuant (Miltenyi Biotec, CA, USA). Os anticorpos utilizados para as marcações foram: CD19 (MB19-1), B220 (RA3-6B2), TCR $\beta$ (H57-597), CD4 (GK1.5), MHC II (M5/114.15.2), CD11c (N418), Ly6C (HK1.4), Ly6G (1A8), CD11b (M1/70), CD8 (53-6.7), IL-17A (TCII-18H10.1), IFN$\gamma(\mathrm{XMG} 1.2), \mathrm{NK} 1.1$ (PK136), TCR $\gamma \delta$ (GL3), CD86 (GL-1), CD40 (3/23), CD62L (MEL-14) e 
CD44 (IM7) (BioLegend, CA, USA ou BD Bioscience). Os dados foram analisados no software FlowJo (Tree Star, Ashland, OR).

\subsection{4 - Sorting celular}

Os sortings celulares foram realizados no FACSAria III (BD Bioscience). Linfócitos naives foram obtidos a partir dos linfonodos cervicais, axilares, mesentéricos e inguinais de

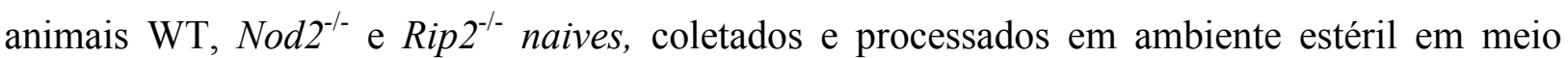
RPMI incompleto contendo $2 \%$ de penicilina e estreptomicina (Sigma). As células foram ressuspensas em um volume final de $500 \mu \mathrm{L}$ e incubadas por 30 minutos com anti-CD4-FITC, anti-CD62L-PE e anti-CD44-PERCP (BD Bioesciences). A população de células $\mathrm{CD}^{+}{ }^{+} \mathrm{CD}_{4}{ }^{-}$ $\mathrm{CD} 2 \mathrm{~L}^{+}$foi utilizada no experimento de polarização de linfócitos in vitro, descrito adiante no item 3.15.

Linfócitos T, B e células dendríticas também foram separadas por sorting do baço de camundongos WT naives e infectados com L. infantum (4 e 6 semanas após a infecção). Para isso, os baços foram coletados e digeridos com $20 \mu \mathrm{g} / \mathrm{mL}$ de Liberase (Roche, Indianapolis, IN, EUA) e $0,05 \%$ de DNAse (Sigma) por 20 minutos a $37^{\circ} \mathrm{C}$. Após digestão, os baços foram macerados e filtrados em cell Strainer de $70 \mu \mathrm{m}$ (BD Biosciences). Seguiu-se um ciclo de centrifugação para posterior lise das hemácias com tampão ACK por 4 minutos a temperatura ambiente. Após lavagem e remoção do tampão de lise, as células foram suspensas em $1 \mathrm{~mL}$ de RPMI incompleto e incubadas por 30 minutos com coquetéis contendo anti-CD3-FITC e antiCD4 APC-Cy7, anti-CD19-PE, ou anti-MHC Classe II-PE-Cy5 e anti-CD11c-PE-Cy7 (BD Bioesciences e eBioscience). As populações celulares $\mathrm{CD}^{+} \mathrm{CD}^{+}, \mathrm{CD}^{-} \mathrm{CD} 19^{+}$e

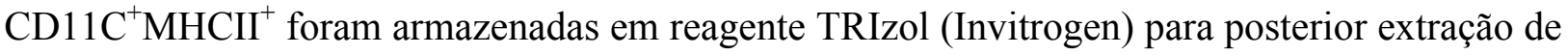
RNA e análise por PCR em tempo real. 


\subsection{5 - Diferenciação de linfócitos}

Linfócitos $\mathrm{T}$ naives $\mathrm{CD} 4^{+} \mathrm{CD} 44^{-} \mathrm{CD}_{2} \mathrm{~L}^{+}$separados por sorting celular de linfonodos de

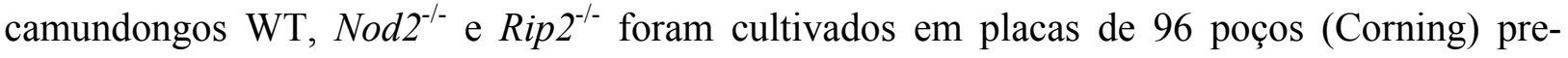
cobertas com $\alpha$-CD3 $(2 \mu \mathrm{g} / \mathrm{mL})$ e $\alpha$-CD-28 $(1 \mu \mathrm{g} / \mathrm{mL})$ (BioXcell, West Lebanon, NH, USA) contendo os coquetéis de diferenciação conforme listados na Tabela III durante 7 dias. As células foram expandidas de acordo com a necessidade. Após o período de diferenciação, as células foram coletadas e analisadas por citometria de fluxo para avaliação da eficiência da diferenciação.

Tabela III: Protocolo de diferenciação de linfócitos T in vitro.

\begin{tabular}{|c|c|c|c|c|c|c|c|c|c|}
\hline & $\begin{array}{l}r I L-2 \\
\text { (BD) }\end{array}$ & $\begin{array}{c}\text { IIL-12 } \\
\text { Biolegend) }\end{array}$ & $\begin{array}{c}r \text { TGF- } \beta \\
\text { Invitrogen) }\end{array}$ & $\begin{array}{l}r \text { IL-6 } \\
\text { (RD) }\end{array}$ & $\begin{array}{c}r \text { IL-1及 } \\
\text { (RD) }\end{array}$ & $\begin{array}{c}r \text { ILL-23 } \\
\text { (RD) }\end{array}$ & $\begin{array}{l}\text { anti-IFN- } \gamma \\
\text { (BioXCell) }\end{array}$ & $\begin{array}{c}\text { anti-IL-2 } \\
\text { (BioXCell) }\end{array}$ & \begin{tabular}{|l|} 
anti-IL-4 \\
(BioXCell)
\end{tabular} \\
\hline Th1 & $25 \mathrm{U} / \mathrm{mL}$ & $5 \mathrm{ng} / \mathrm{mL}$ & - & - & - & - & - & - & $10 \mu \mathrm{g} / \mathrm{mL}$ \\
\hline Th17 & - & - & $5 \mathrm{ng} / \mathrm{mL}$ & $20 \mathrm{ng} / \mathrm{mL}$ & $20 \mathrm{ng} / \mathrm{mL}$ & $50 \mathrm{ng} / \mathrm{mL}$ & $10 \mu \mathrm{g} / \mathrm{mL}$ & $10 \mu \mathrm{g} / \mathrm{mL}$ & $10 \mu \mathrm{g} / \mathrm{mL}$ \\
\hline
\end{tabular}

\subsection{6 - Western blot}

BMDCs foram cultivadas em placas de 24 poços não tratadas para aderência na concentração de $5 \times 10^{5}$ células $/ \mathrm{mL}$ no volume de $1 \mathrm{~mL}$ por poço. As células foram infectadas com L. infantum (5 parasitos/célula) por 30 min e coletadas em $60 \mu \mathrm{L}$ de tampão RIPA (Sigma) contendo os inibidores Phosphostop fosfatase e Complete protease (Roche, Basileia, Suíça). As amostras foram armazenadas a $-80^{\circ} \mathrm{C}$ até o momento do uso. A quantificação das proteínas foi feita com reagente Bradford (Sigma) de acordo com as recomendações do fabricante. Os lisados celulares foram diluídos em tampão de amostra 4X (EMD Millipore, MA, EUA), aquecidos a $90^{\circ} \mathrm{C}$ por 6 min e então aplicados $50 \mu \mathrm{g}$ de proteína/amostra em gel de poliacrilamida a $10 \%$ para corrida a $100 \mathrm{~V}$. A membrana de nitrocelulose (GE Healthcare, USA) e demais 
componentes para transferência foram incubados em tampão de transferência (50 mM Tris, 40 $\mathrm{mM}$ glicina e $20 \%$ metanol) por $5 \mathrm{~min}$ a temperatura ambiente. A transferência foi feita utilizando o sistema Semidry Transfer Cell (Bio-Rad Laboratories, USA) a 15 volts por 40 minutos. O bloqueio foi feito por $1 \mathrm{~h}$ a temperatura ambiente com BSA 3-5\% diluído em TBS-T (Tris buffered saline) [25 mM Tris (Hexis Científica, SP, Brasil), pH 7.4 + 0,3 mM KCl (J.T. Baker, PA, EUA) + 140 mM NaCl (J.T. Baker) + 0,1\% Tween-20 (Sigma)]. Após o bloqueio, as membranas foram incubadas por $16 \mathrm{~h}$ sob agitação leve, a $4^{\circ} \mathrm{C}$, com os anticorpos anti-JNK fosforilada, anti-JNK total, anti-ERK1/ERK2 fosforilada, anti-ERK1/ERK2 total, anti-p38 fosforilada ou anti-p38 total (Cell Signalling Technologies) diluídos em bloqueio. Três ciclos de lavagem de 10 min cada foram feitos, também sob agitação, com TBS-T antes da incubação com os anticorpos secundários apropriados conjugado com peroxidase. A detecção da reação foi feita com o reagente ECL Luminol (GE Healthcare) e filme Hyperfilm (GE Healthcare).

\subsection{7 - Cocultura}

BMDCs foram infectadas com 5 parasitos/célula e mantidas em estufa de $\mathrm{CO}_{2}$ a $37^{\circ} \mathrm{C}$ por $5 \mathrm{~h}$, sendo homogeneizadas a cada hora. Após esse período, elas foram lavadas 5 vezes $(50 \mathrm{x}$ g, 5 min) para remoção dos parasitos extracelulares, contadas e plaqueadas na concentração de $10^{4} / 100 \mu \mathrm{L}$ em placas de 96 poços de fundo U. As BMDCs foram pulsadas com OVA (100 $\mu \mathrm{g} / \mathrm{mL}$ ) por 45 min. Células OT-II específicas para OVA foram isoladas com kit de seleção negativa Miltenyi Biotec) e cocultivadas com as BMDCs (5 linfócitos/ 1 célula dendrítica) no volume final de $200 \mu \mathrm{L}$. Após 5 dias do início da cocultura, as células foram coletadas e analisadas por citometria de fluxo. 


\subsection{8 - Análises estatísticas}

Significâncias estatísticas em comparações simples entre dois grupos foram avaliadas pelo teste t. Em comparações de múltiplos grupos foram feitas análise de variância (ANOVA) seguida pelo pós-teste de Bonferroni (GraphPad Software Inc., San Diego CA, EUA). As diferenças que apresentaram valores de $\mathrm{p}<0,05$ foram consideradas estatisticamente significativas. 
IV. Resultados 


\section{1 - Células Th17 são inibidas durante a leishmaniose visceral por Leishmania infantum}

A infecção por L. infantum desencadeia uma resposta imune celular complexa, seja o hospedeiro resistente ou suscetível. Nós demonstramos previamente que camundongos e pacientes produzem IL-17A após a infecção, a qual, juntamente com IFN- $\gamma$, aumenta a capacidade leishmanicida de macrófagos via produção de NO (Nascimento et al., 2015). A fonte celular de IL-17A após a infecção por L. infantum, entretanto, permanece desconhecida. Para investigar a modulação do perfil Th17 na LV, nós analisamos dados gerados por RNAseq de amostras de pacientes antes e após o tratamento (T. LV), e indivíduos com infecção assintomática, comparando-os com controles saudáveis. De maneira intrigante, os dados mostraram que genes relacionados com o perfil Th17; Ahr, Illb, Il17ra, Stat3, Il6r e Rorc; são inibidos em pacientes com LV, antes ou após o tratamento, comparados com sujeitos controles não infectados (Fig. 3). Por outro lado, genes relacionados com Th1; Il12b, Il10, Ifng e Ebi3; são induzidos nesses grupos (Fig. 3). Indivíduos assintomáticos apresentaram regulação positiva da expressão gênica para $A h r, I l l b$ e Ccr4, porém regulou negativamente Ifng e Ebi3, comparado com pacientes com LV (Fig 3).

Com o objetivo de investigar se o padrão de indução de Th1 e inibição de Th17 na LV é reproduzível em modelo experimental, de modo que nos permitiria estudar os mecanismos e as consequências envolvidas nessa modulação, nós infectamos camundongos C57BL/6 (WT) com $10^{7}$ parasitos em fase estacionária de crescimento via intravenosa (o modelo de infecção será o mesmo para os outros experimentos no decorrer do trabalho) e 4 semanas após a infecção o baço dos animais foi coletado para análise da produção de IL-17A por células T CD4 ${ }^{+}, \mathrm{T}$ CD $8^{+}, \mathrm{T} \gamma \delta$, células NK e células B. Nós observamos que linfócitos Th17 $\left(\mathrm{CD} 4^{+} \mathrm{TCR} \beta^{+} \mathrm{IL}_{-1} 17 \mathrm{~A}^{+}\right)$foram detectadas em frequências muito baixas, $0,55 \%$ do total de $\mathrm{CD} 4^{+} \mathrm{TCR} \beta^{+}$eram produtoras de 


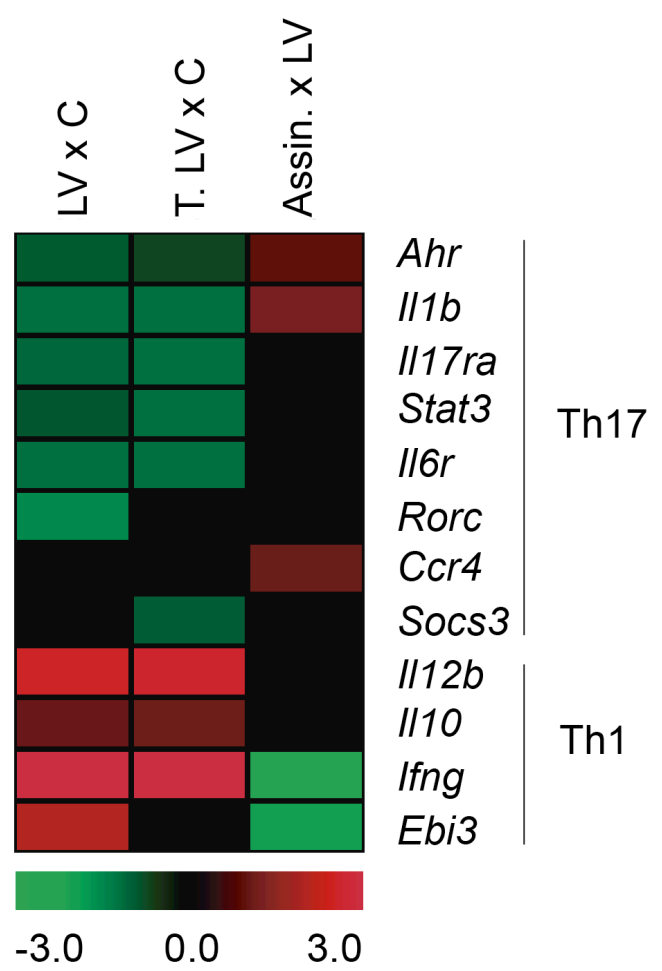

Figura 3: Regulação da expressão de genes relacionados às respostas Th1 e Th17 em leucócitos de sangue periférico humano. O heatmap apresenta valores de log2FC (FC, fold change) de indivíduos com leishmaniose visceral antes do tratamento (LV) e após seis meses de tratamento (T. LV), ambos comparados a indivíduos saudáveis (C, controles), LV x C e T. LV x C, respectivamente; e de indivíduos assintomáticos (Assin.) comparados aos indivíduos com LV (Assin. $x$ LV). A escala de cores representa genes regulados negativamente (em verde) e genes regulados positivamente (em vermelho) para as três comparações.

IL-17A (Fig. 4A). Em contrapartida, 11\% da população de CD4 ${ }^{+}$TCR $\beta^{+}$eram Th1 (Fig. 4A). De maneira curiosa, a análise na população de células $\mathrm{B} C D 19^{+} \mathrm{CD} 4^{-T C R} \beta^{-}$mostrou tanto produção de IL-17A (0,22\%) quanto de IFN- $\gamma(0,47 \%)$ (Fig. 4B), sendo que, dentro da população total de células produtoras de IL-17A, 48,5\% das células são $\mathrm{CD} 19^{+} ; 24,7 \%$ são duplo negativas e somente $18,3 \%$ são linfócitos $\mathrm{T} \mathrm{CD}^{+}$(Fig. 4C). A produção de IL-17A por células T CD8 ${ }^{+}, \mathrm{T}$ $\gamma \delta$ e NK foi irrelevante (Fig. 4D). Esses dados mostram que linfócitos Th17 não são induzidos, ou são induzidos em quantidades muito baixas e, nesse contexto, dentre as células analisadas, as células B são as mais frequentes dentro da população de células IL-17A+. 
A

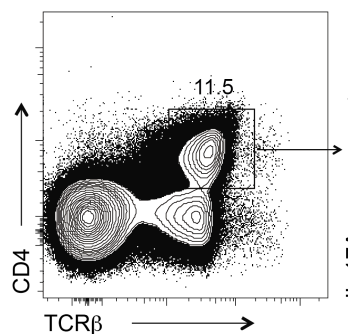$$
\text { TCR }
$$
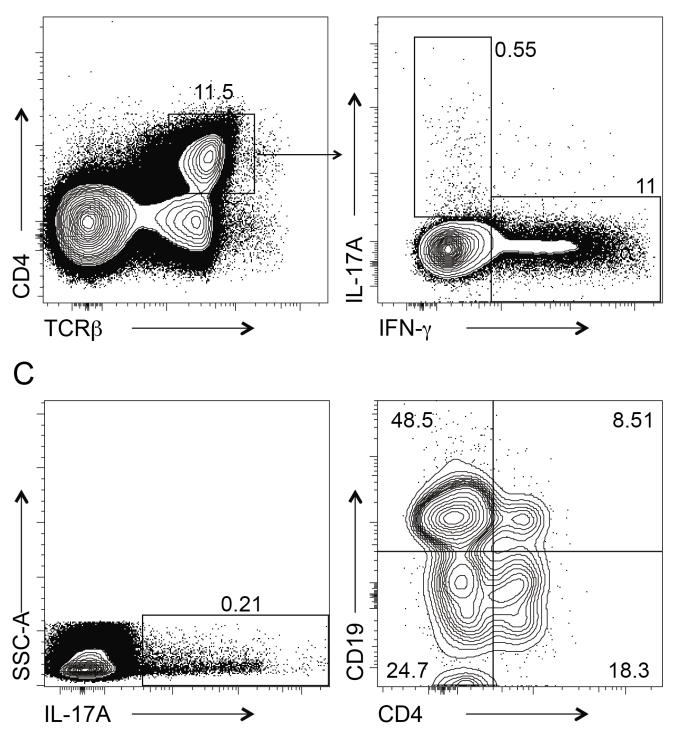

D

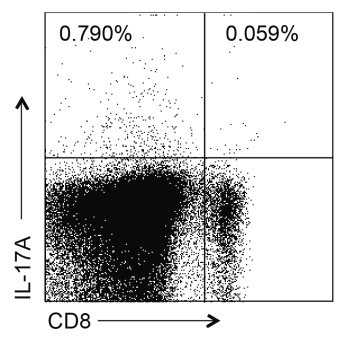

B
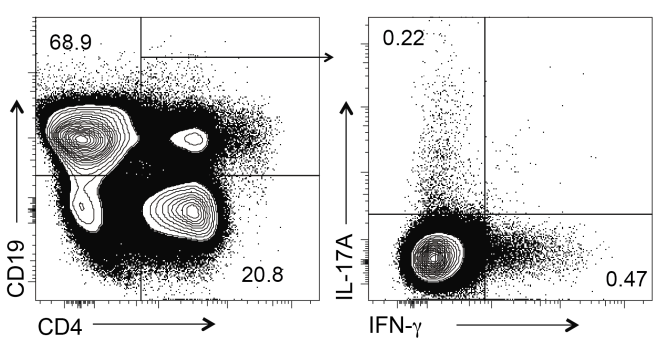

Figura 4: Células B CD19 ${ }^{+} \mathrm{CD}^{-}{ }^{-T C R} \beta^{-}$são importante fonte de IL-17A durante a infecção por $L$. infantum. Camundongos WT foram infectados com $10^{7}$ parasitos em fase estacionária de crescimento por via intravenosa. Após 4 semanas de infecção o baço foi coletado e os linfócitos foram estimulados com PMA e ionomicina por $4 \mathrm{~h}$ para posterior análise por citometria de fluxo. A produção de IL-17A e IFN- $\gamma$ foi analisada na população de células $\mathrm{CD}^{+} \mathrm{TCR}^{+}$(A) e $\mathrm{CD}^{+} 9^{+} \mathrm{CD}^{-}$(B). A população IL-17A ${ }^{+}$foi analisada quanto a expressão de CD4 e CD19 (C). Expressão de IL-17A nas populações de células T $\mathrm{CD}^{+}$, células NK e células $\mathrm{T} \gamma \delta(\mathbf{D})$. N=3-5 camundongos. Representativo de 5 experimentos independentes com resultados semelhantes.

Sendo IFN- $\gamma$ e IL-17A duas citocinas inflamatórias chaves para promover resistência contra a infecção por L. infantum, nós investigamos em seguida o porquê de Th1 ser significativamente induzido e Th17 praticamente inexistente nesse modelo. A análise da modulação da expressão gênica em camundongos infectados com L. infantum foi uma ferramenta muito útil para entender essa questão. Nós realizamos um PCR array do fígado, órgão alvo da proliferação parasitária e recrutamento linfocítico, de camundongos não 
infectados (NI), e na $4^{\mathrm{a}}$ e $6^{\mathrm{a}}$ semanas após a infecção (s.a.i.). A integridade e a qualidade do RNA foram averiguadas através da corrida de eletroforese no Bioanalyser (Fig. 5A). A qualidade do RNA é demonstrada através do RIN (RNA Integrity Number) no eletroferograma (Fig. 5B).

Através do PCR array nós triamos 84 genes relacionados com as respostas imunes inata e adaptativa. Dentre eles, 56 transcritos foram regulados positivamente na $4^{\mathrm{a}}$ semana após a infecção, e 52 transcritos na $6^{\text {a }}$ semana, sendo 50 deles em comum (Fig. 6A, B e Tabela IV). Oito transcritos foram regulados negativamente tanto na quarta quanto na sexta semanas após a infecção, sendo 4 compartilhados (Csf2, H2-Q10, Ifna2, Tlr5) (Figs. 6A, B e Tabela IV). De maneira geral, o perfil de expressão gênica no fígado nos dois períodos após a infecção analisados foi bem semelhante, e, em conjunto, foram distintos do padrão de expressão apresentado na ausência de infecção (Fig. 6C). Como esperado, Ifng, Tbx21 e Il17a estavam entre os transcritos regulados positivamente tanto na $4^{\mathrm{a}}(101.9591,28.5441$ e 3.6836 vezes, respectivamente) quanto na $6^{\mathrm{a}}$ semana após a infecção $(53.7287,22.7839$ e 7.9639 vezes, respectivamente) (Fig. 7A e B). Confirmando os dados da citometria, que demonstrou uma inibição de células T $\mathrm{CD} 4^{+} \mathrm{TCR} \beta^{+}$produtoras de IL-17A, e corroborando os dados encontrados em humanos, nós observamos que Rorc, fator de transcrição de assinatura de células Th17 (Ivanov et al., 2006), é inibido na $4^{\mathrm{a}}$ semana após a infecção, e permanece com nível semelhante ao naive na $6^{\mathrm{a}}$ semana (Fig 7A e B). 
A

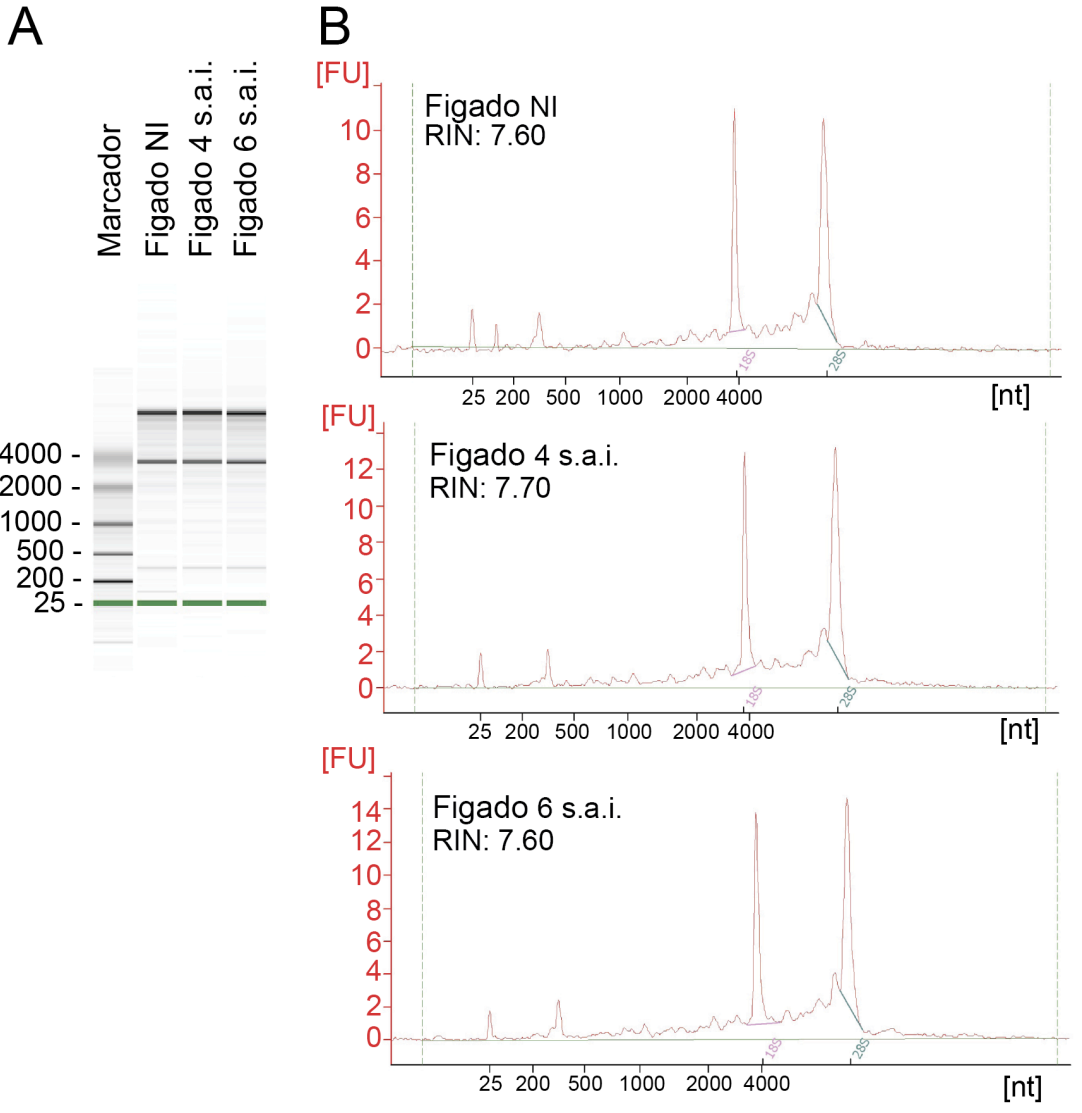

Figura 5: Integridade e qualidade do RNA extraído do fígado de camundongos não infectados (NI) e na $4^{\mathrm{a}}$ e $6^{\mathbf{a}}$ semanas após a infecção (s.a.i.). Camundongos WT foram infectados com $10^{7}$ parasitos em fase estacionária de crescimento por via intravenosa, ou mantidos não infectados. Após 0,4 e 6 semanas de infecção o fígado foi coletado e o RNA foi extraído. A qualidade do RNA foi checada através da corrida de eletroforese no Bioanalyser (A). Resumo do eletroferograma (B). s.a.i., semanas após a infecção. RIN, RNA Integrity Number. 
A

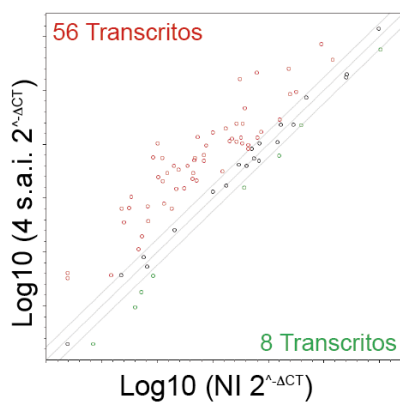

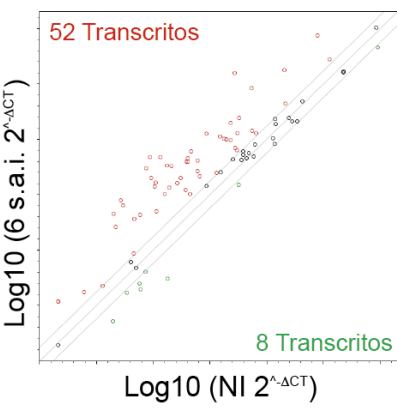

B

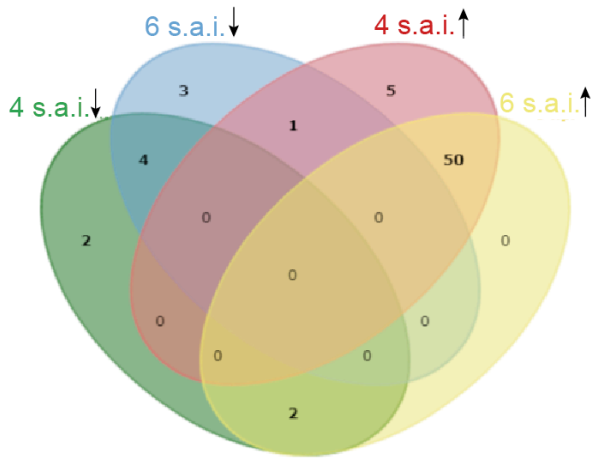

C

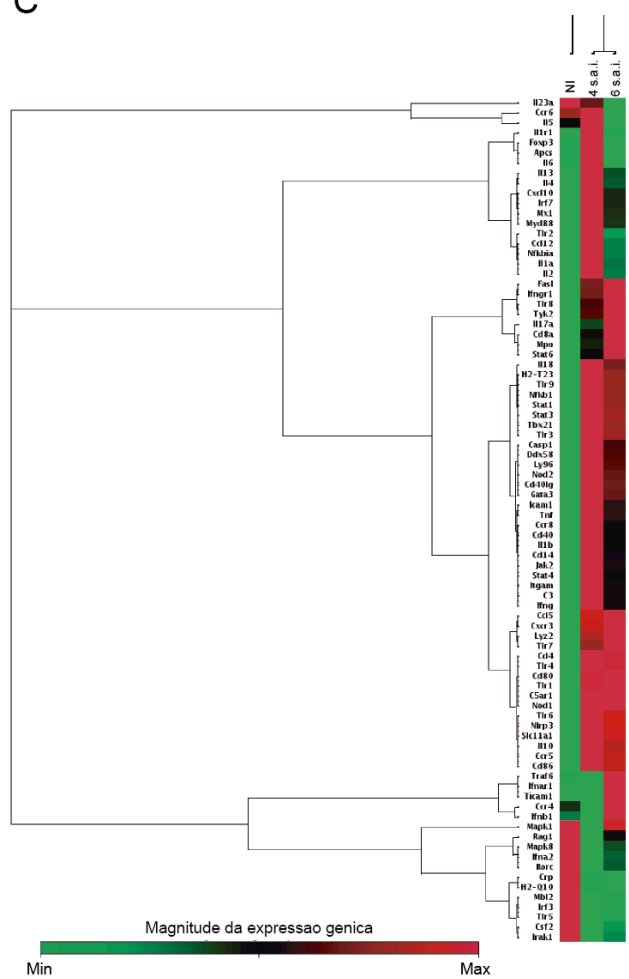

Figura 6: Análise do PCR array do fígado de camundongos após 4 e 6 semanas de infecção (comparado com controle não infectado). Camundongos WT foram infectados com $10^{7}$ formas promastigotas em fase estacionária de crescimento, ou mantidos não infectados e usados como controle. Após 4 e 6 semanas de infecção o fígado foi coletado para análises por PCR array. O gráfico de dispersão mostra a comparação da expressão normalizada de cada gene no array entre o grupo controle não infectado (NI, no eixo X) contra o grupo teste (4 ou 6 s.a.i., semanas após infecção, no eixo Y). As mudanças positivas de expressão gênica são representadas em vermelho, as alterações negativas em verde, e as que permaneceram dentro do limiar de 1,75, não alteradas, em preto (A). O diagrama de Venny foi construído a partir dos valores de regulações positiva ou negativa dos transcritos. A análise foi feita em http://bioinfo.genotoul.fr/index.php?id=116 (B). O clustergrama demonstra o agrupamento hierárquico não supervisionado do conjunto de dados inteiro, exibindo um mapa de calor com dendrogramas indicando genes corregulados entre os grupos 'não infectado' (NI) (1 $1^{\text {a }}$ coluna), 4 s.a.i. ( $2^{\text {a }}$ coluna) e 6 s.a.i. ( $3^{\text {a }}$ coluna) (C). As análises representadas em $\mathbf{A}$ e $\mathbf{C}$ foram feitas em http://pcrdataanalysis.sabiosciences.com/pcr/arrayanalysis.php. Os dados são representativos de um experimento feito com pool de 4 animais para cada grupo. s.a.i., semanas após a infecção. $\uparrow$, regulação positiva. $\downarrow$, regulação negativa. 
Tabela IV: Alterações na expressão gênica no fígado de camundongos WT após 4 e 6 semanas de infecção com L. infantum. Dados comparados ao controle não infectado.

\begin{tabular}{|c|c|}
\hline $\begin{array}{c}\text { Semanas após infecção } \\
\text { (s.a.i) }\end{array}$ & Genes com expressão alterada \\
\hline 4 s.a.i $\downarrow$ & Irf3; Rorc \\
\hline 6 s.a.i $\downarrow$ & Ccr6; Il23a; Il5 \\
\hline 4/6 s.a.i $\downarrow$ & Csf2; H2-Q10; Ifna2; Tlr5 \\
\hline 4 s.a.i $\uparrow$ & Apcs; Illa; Il4; Ly96; Stat3 \\
\hline 4/6 s.a.i $\uparrow$ & $\begin{array}{c}\text { C5ar1; Casp1; Ccl12; Ccl5; Ccr5; Ccr8; Cd14; Cd4; Ifng; Cd40; Cd40lg; } \\
\text { Cd80; Cd86; Cd8a; Cxcl10; Cxcr3; Fasl; Gata3; H2-T23; Icam1; Ifngr1; Illo, } \\
\text { Il13; Il17a; Il1b; Il2; Irf7; Tnf; Itgam; Jak2; Lyz2; Mpo; Mx1; Myd88; Nfkb1; } \\
\text { Nlrp3; Nod1; Nod2; Slc11a1; Stat1; Stat4; Tbx21; Tlr1; Tlr2; Tlr3; Tlr4; Tlr6; } \\
\text { Tlr7; Tlr8; Tlr9 }\end{array}$ \\
\hline
\end{tabular}

$\uparrow$, regulação positiva. $\downarrow$, regulação negativa.

A

Figado - 4 s.a.i.

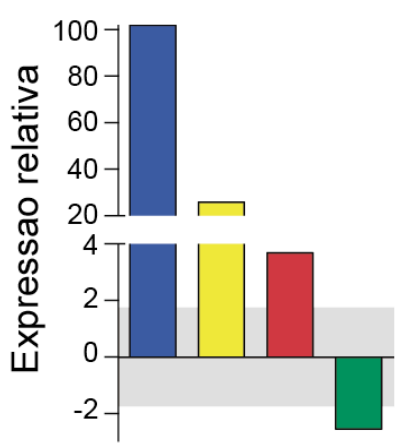

B

Figado - 6 s.a.i.

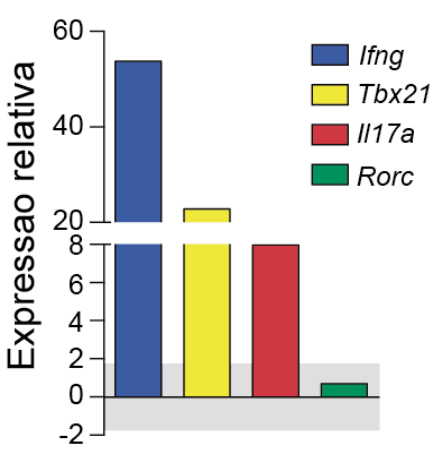

Figura 7: A expressão de transcritos de Ifng, $T b x 21$ e $I l 17 a$ são induzidos, mas o RNAm de Rorc é reprimido após a infecção por $L$. infantum. Camundongos WT foram infectados com $10^{7}$ formas promastigotas em fase estacionária de crescimento, ou mantidos não infectados e usados como controle. Após 4 (A) e 6 (B) semanas de infecção o fígado foi coletado para análises por PCR array. As variações relativas na expressão gênica de Ifng (azul), Tbx21 (amarelo), Il17a (vermelho) e Rorc (verde) são demonstradas no eixo Y. A área em cinza representa o ponto de corte de 1,75, e mostra genes com expressão inalterada. O gene da ßactina foi usado como controle constitutivo para as normalizações. Esses resultados são representativos de 1 experimento realizado com pool de tecido de 4 animais por grupo. s.a.i., semanas após a infecção. 


\section{2 - Leishmania infantum induz a expressão de NOD2, o qual modula a resposta imune adaptativa}

Tentando entender como ocorre a modulação negativa de células Th17 após a infecção, ainda utilizando os dados do PCR array, nós analisamos a expressão gênica de moléculas sabidamente moduladoras do perfil Th17. Nós vimos que as citocinas polarizadoras do perfil Th17, Illb e Il6 tiveram sua expressão gênica regulada positivamente na $4^{\mathrm{a}}$ semana de infecção, porém Il6 foi modulado negativamente na $6^{\text {a }}$ semana (Fig. 8A e B). A $I l 23 a$ (ou $I l 23 p 19$ ) teve expressão relativa de -1.2211 e -2.2844 na $4^{\mathrm{a}}$ e $6^{\mathrm{a}}$ semanas após infecção, respectivamente (Fig. 8A e B). A via de sinalização de NOD2 tem sido descrita como modulador negativo da expressão de IL-23, regulando, portanto, a diferenciação de células Th17 (Brain et al., 2013). Por essa razão, essa molécula/via se tornou alvo do nosso estudo. Nossos dados mostraram que o RNA mensageiro para Nod2 teve sua expressão aumentada na $4^{\mathrm{a}}$ e $6^{\mathrm{a}}$ semana de infecção (Fig. 8A e B). Esses dados foram confirmados por PCR em tempo real (Fig. 8C), em que também observamos o aumento da expressão de transcritos para Rip2 (Fig. 8D).

NOD2 é uma proteína expressa preferencialmente em APCs (Inohara et al., 2005), e RIP2 é a molécula adaptadora da sua via de sinalização. Dentre as APCs, as células dendríticas são as melhores em iniciar a resposta adaptativa, pois possuem uma maquinaria celular especializada para essa função (Rossi e Young, 2005). Baseado nesse conhecimento e no nosso objetivo de analisar como ocorre a modulação da resposta imune adaptativa, nós verificamos a expressão de Nod2 e Rip2 em BMDCs. A infecção por L. infantum aumentou a transcrição de Nod2 e Rip2 em BMDCs (Figs. 9A e B) e ainda potencializou a expressão desses transcritos quando as células foram ativadas com MDP, ligante descrito para NOD2 (Figs. 9A e B), LPS, ligante descrito para TLR4 (Figs. 9C e D) e Listeria monocytogenes, bactéria descrita como ativadora da via de NOD2-RIP2 (Figs. 9C e D). 
A

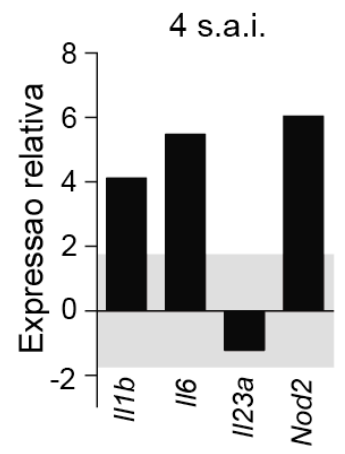

B

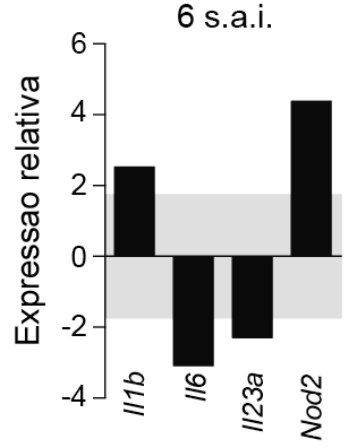

C

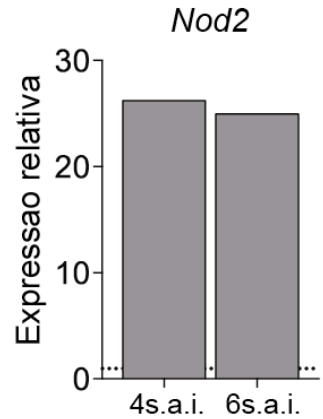

D

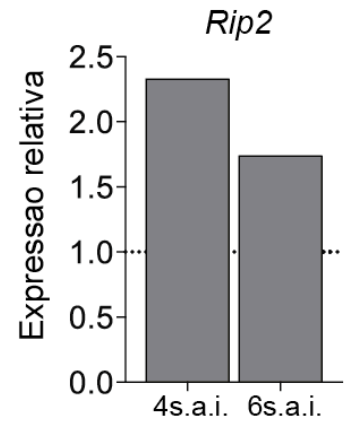

Figura 8: A infecção por $L$. infantum induz a expressão de RNAm de Nod2 e Rip2 no fígado de camundongos. Animais WT foram infectados com $10^{7}$ formas promastigotas em fase estacionária de crescimento, ou mantidos não infectados e utilizados como controle. Após 4 (A) e 6 (B) semanas de infecção o fígado foi coletado para análises por PCR array. As variações relativas na expressão gênica para $I l 1 b, I l 6, I l 23$ e Nod2 são demonstradas no eixo Y. A área em cinza representa o ponto de corte de 1,75 , e mostra genes com expressão inalterada. O gene da $\beta a c t i n a$ foi usado como controle constitutivo para as normalizações. Esses resultados são representativos de 1 experimento realizado com pool de tecido de 4 animais por grupo. Essas mesmas amostras foram analisadas por PCR em tempo real. A expressão relativa para $\operatorname{Nod} 2$ (C) e $\operatorname{Rip} 2$ (D) é mostrada no eixo Y. A linha pontilhada representa a expressão em animais não infectados. s.a.i., semanas após a infecção.
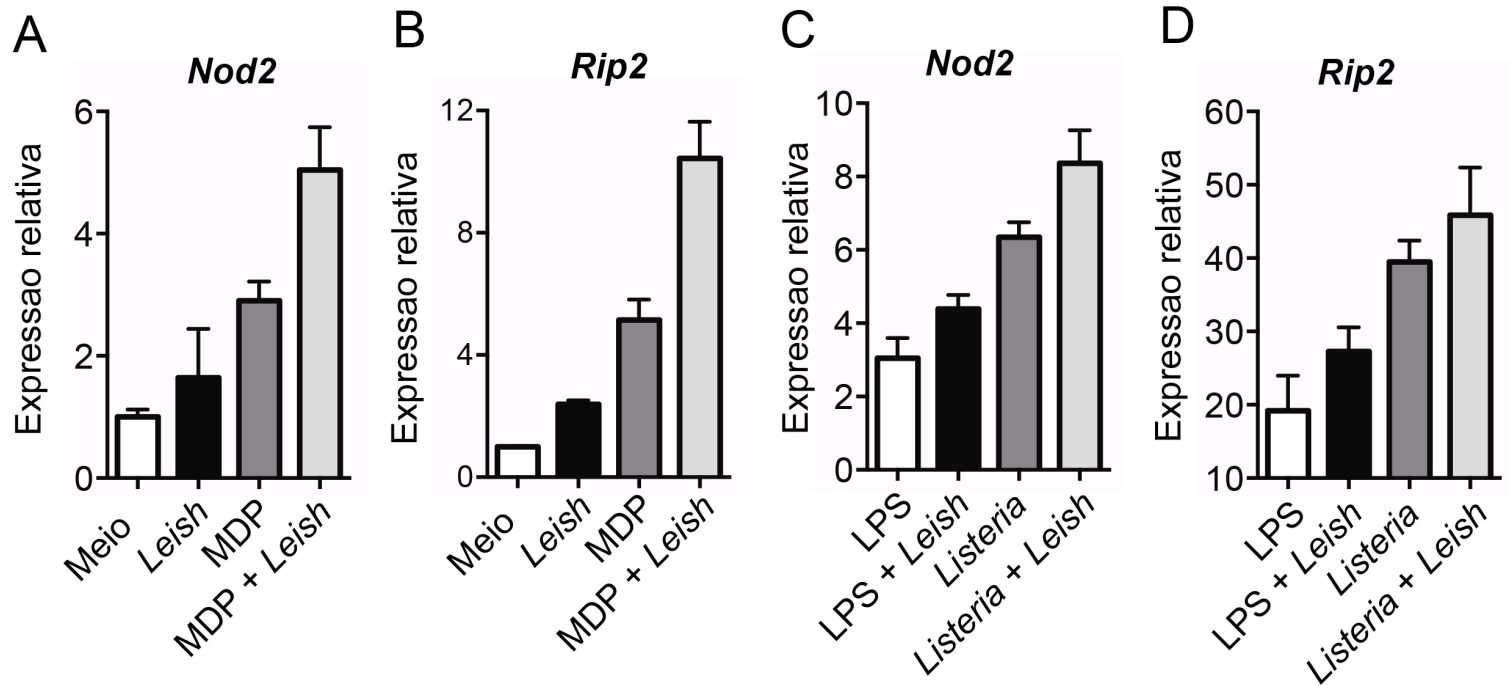

Figura 9: L. infantum induz a expressão de RNAm de Nod2 e Rip2 em BMDCs. Células dendríticas foram diferenciadas a partir de precursores da medula óssea de camundongos WT. As células foram mantidas inativadas (barras brancas em A e B), infectas com L. infantum (5 parasitos/ célula; barras pretas em A e B), transfectadas com MDP (10 $\mu \mathrm{g} / \mathrm{mL}$; barras cinza escuro em A e B) ou ambos (barras cinza claro em A e B) (A e B); ou estimuladas com LPS (200 ng/mL; barras brancas em C e D), infectadas com Listeria monocytogenes (5 CFU/ célula; barras cinza escuro em $\mathbf{C}$ e D) e/ou infectadas com Leishmania após 2 h de estímulo com LPS (barras pretas em C e D) ou infecção com Listeria (barras cinza claro em $\mathbf{C}$ e D) (C e B). Após 6 h de estímulo as células foram coletadas e analisadas quanto à expressão de RNAm para Nod2 e Rip2. Esses resultados são representativos de 3 experimentos independentes com resultados semelhantes realizado em quadruplicata. 
Após observar a expressão do RNA mensageiro para moléculas importantes no nosso estudo, nós tivemos o interesse em analisar a expressão das proteínas correspondentes in vivo e in vitro e, além disso, como elas estariam organizadas na célula após a infecção. Para responder a essa questão, nós realizamos uma reação de imunofluorescência para NOD2 no baço de camundongos WT após $6 \mathrm{~h}$ de infecção, momento em que a primeira leva de migração de células dendríticas da polpa vermelha para polpa branca atinge o seu ponto máximo. A Figura 10 mostra um folículo contornado por macrófagos metalofílicos, identificados através da expressão de MOMA/CD169, em verde, e que separa a polpa branca (interna - área de linfócitos T e B) da polpa vermelha (externa). Nós observamos que, de fato, 6h após a infecção, células dendríticas (CD11 ${ }^{+}$, mostrado em azul) estão acumuladas na polpa branca e que camundongos naives possuem uma expressão basal de NOD2 que não é restrita às células dendríticas. Após a infecção, a expressão de NOD2 em células dendríticas se torna mais evidente, porém outras células também o expressam (Fig. 10A). De maneira interessante, a expressão de NOD2 em BMDCs é bastante aumentada após a infecção, em relação às células não infectadas e, além disso, é colocalizada com o parasito, sugerindo uma possível interação (Fig. 10B, ver vídeo em anexo). 
A
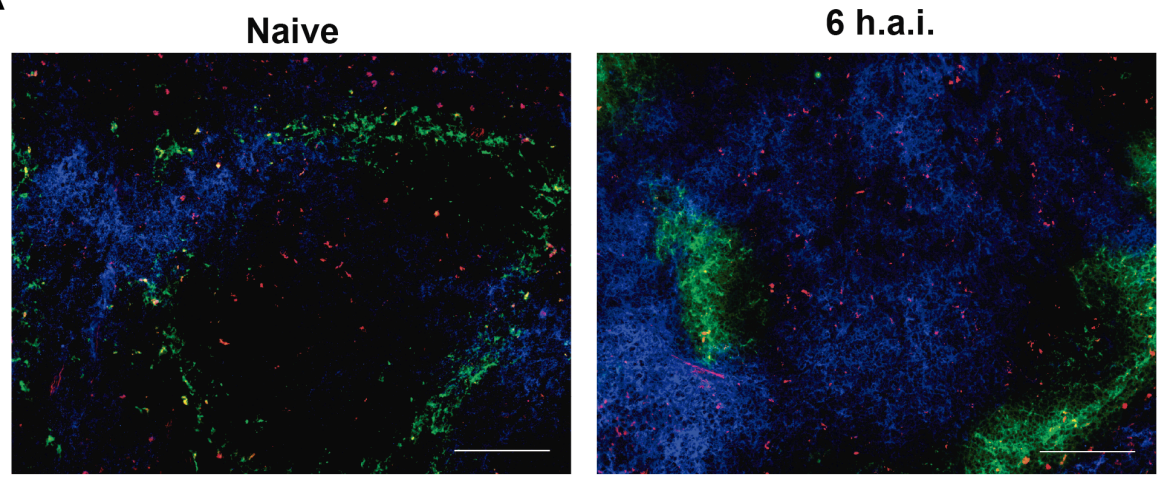

B
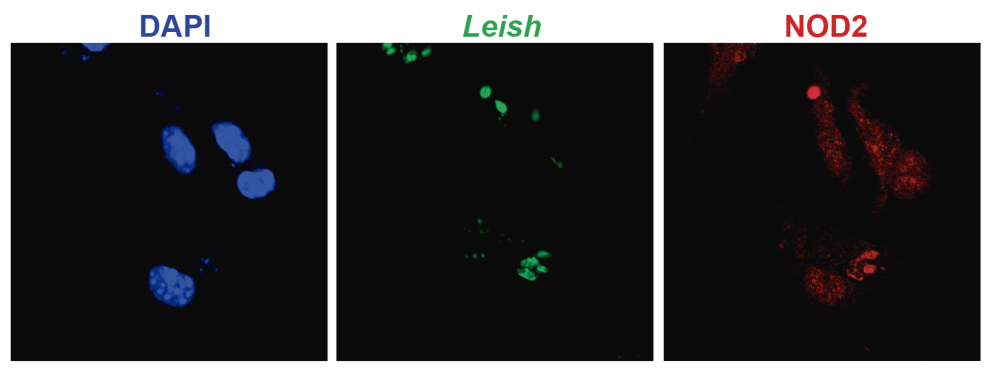

Sobreposicao

CD11C

MOMA

NOD2

Figura 10: NOD2 colocaliza com o parasito na célula dendrítica infectada. Camundongos WT foram infectados com $10^{7}$ parasitos em fase estacionária de crescimento e 6 horas após a infecção (h.a.i.) os baços dos animais foram coletados para análise por imunofluorescência. A imagem mostra a marcação de CD11c em azul, MOMA/CD169 em verde e NOD2 em vermelho. Escala $=100 \mu \mathrm{m}$ (A). BMDCs foram infectadas com Leishmania marcada com CFSE (5 parasitos:1 célula). Após 24 h de infecção as células foram analisadas em microscópio confocal. Em azul estão marcados o núcleo celular com DAPI, a Leishmania é mostrada em verde e o NOD2 em vermelho. Fotomicrografia com aumento de $\sim 1000 \mathrm{X}$ (Objetiva de 100X) (B). Esses resultados estão expressos em intensidade de fluorescência e são representativos de 2-4 experimentos independentes com resultados semelhantes.

Com o objetivo de verificar se a via de NOD2-RIP2 estaria atuando como repressor da resposta Th17 na VL, nós infectamos camundongos WT, Nod2 $2^{-/-}$e Rip2 $2^{-/-}$e analisamos a resposta Th17 no baço e no fígado desses animais após 4 semanas de infecção. Foi observado que enquanto animais WT apresentaram $1,45 \%$ de células $\mathrm{CD}^{+} \mathrm{CD}^{+} \mathrm{IL}^{-17 \mathrm{~A}^{+}}$no baço, camundongos $\mathrm{Nod}_{2}{ }^{-/-}$e $\mathrm{Rip} 2^{-/-}$tiveram $2,63 \%$ e $2,36 \%$, respectivamente (Fig. 11A). Uma maior porcentagem de linfócitos Th17 também foi observado no fígado de animais $\mathrm{Nod} 2^{-/-}$e Rip2 $2^{-/}$, com elevação de 4,1 vezes nos camundongos $\operatorname{Nod}^{-/-}$e 3,1 vezes em animais Rip2 $2^{-/-}$comparados aos camundongos WT (Fig. 11B). Esse dado sugere que na ausência de NOD2 e RIP2 as células Th17 tem sua diferenciação facilitada. 
A

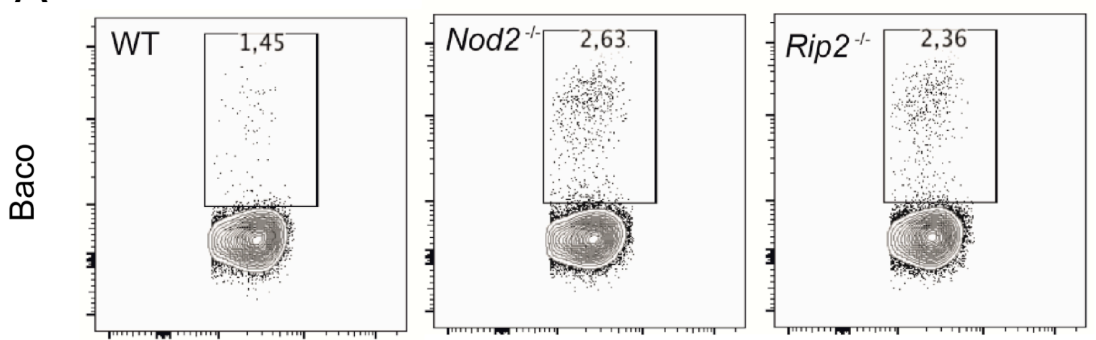

B

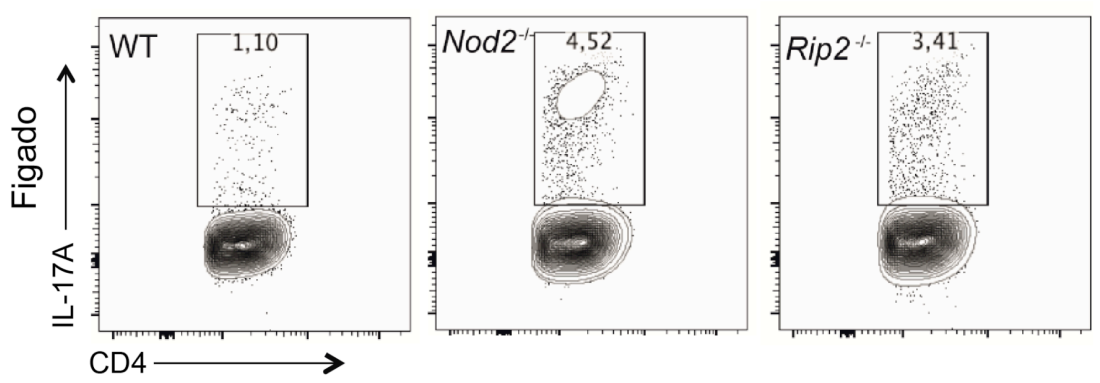

Figura 11: Células Th17 são inibidas pela via de NOD2-RIP2. Camundongos WT, Nod2 ${ }^{-/-}$e Rip $2^{-/-}$foram infectados com $10^{7}$ parasitos em fase estacionária de crescimento. Após 4 semanas de infecção o baço (A) e o fígado (B) foram coletados. As células foram estimuladas com PMA e ionomicina por 4h e então analisadas por citometria de fluxo quanto a produção de IL-17A. As análises foram feitas dentro da população de linfócitos viáveis $\mathrm{CD}^{+}$. Os dados são representativos de 3 experimentos independentes com resultados semelhantes. $\mathrm{N}=4$ camundongos/ grupo.

Sabendo que os animais $\operatorname{Nod}^{-/-}$e Rip $2^{-/-}$apresentaram mais células T produtoras de IL17A após a infecção por L. infantum, nós fizemos a hipótese de que eles seriam mais resistentes à infecção, uma vez que IL-17A possui papel protetor nesse modelo. Inesperadamente, os

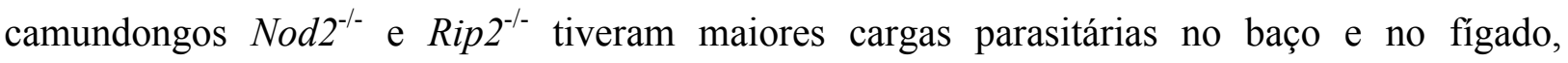
comparados com camundongos WT (Figs. 12A e B) e, além disso, apresentaram maior hepatoesplenomegalia (Figs 12C-F), demonstrando que mesmo com maior quantidade de células Th17 no baço e no fígado, na ausência de NOD2 e RIP2 os animais são mais suscetíveis à infecção por L. infantum. Tentando entender essa questão, nós analisamos a resposta Th1 desses animais, já que esse subtipo é o principal relacionado à resistência contra as leishmanioses em humanos, cães e camundongos. Os dados mostraram que, enquanto camundongos WT expressavam $28,5 \%$ e $32,4 \%$ de células T produtoras de IFN- $\gamma$ no baço e no 
fígado, respectivamente, os deficientes para NOD2 e RIP2 reduziram essa porcentagem para 8,4\% e 9,72\% no baço, e 17\% e 20,3\% no fígado, respectivamente (Figs. 13A e B). Juntos, esses dados demonstram que a via de sinalização de NOD2-RIP2 induz a polarização de células Th1 e inibe células Th17 durante a infecção por L. infantum, impactando no perfil de susceptibilidade desses animais.

A

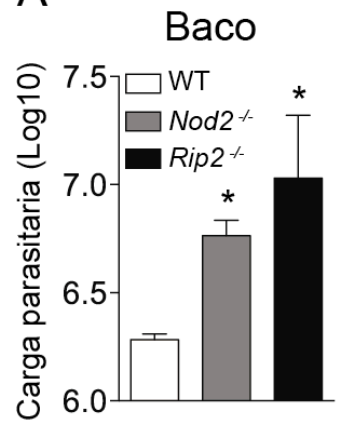

B

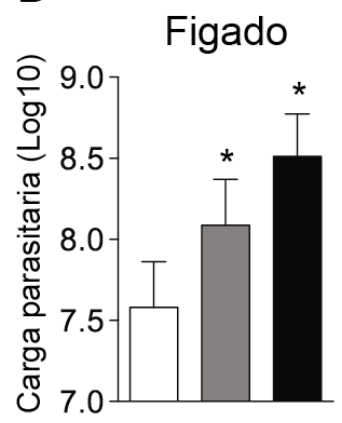

C

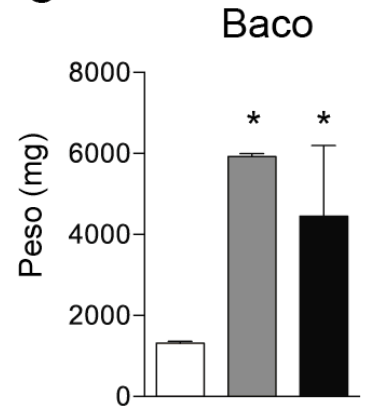

$\mathrm{D}$

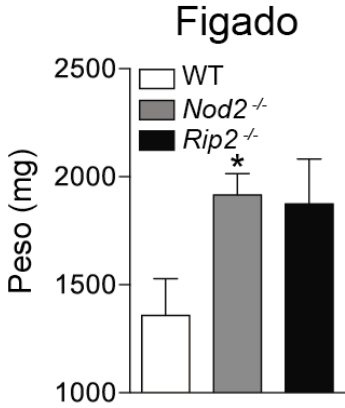

$E$

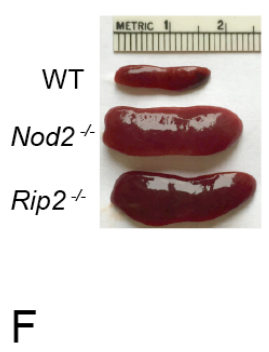

$\mathrm{F}$

WT
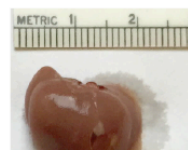

Nod2 ${ }^{-1}$

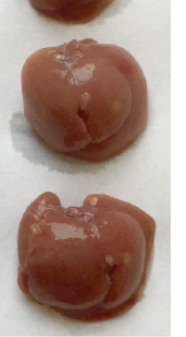

Figura 12: Camundongos $\operatorname{Nod}^{-/-}$e Rip ${ }^{-/-}$são mais suscetíveis a infecção por L. infantum. Animais WT, Nod2 $2^{-/-}$ e $\operatorname{Rip}^{-/-}$foram infectados com $10^{7}$ parasitos em fase estacionária de crescimento. Após 4 semanas de infecção o baço (A) e o fígado (B) foram coletados para análise da carga parasitária por diluição limitante, e para serem pesados (C e D) e fotografados ( $\mathbf{E}$ e $\mathbf{F})$. Os dados são representativos de 3 experimentos independentes com resultados semelhantes. $\mathrm{N}=4-5$ animais/grupo. ${ }^{*}, \mathrm{p}<0,05$ comparado com o WT. 
A
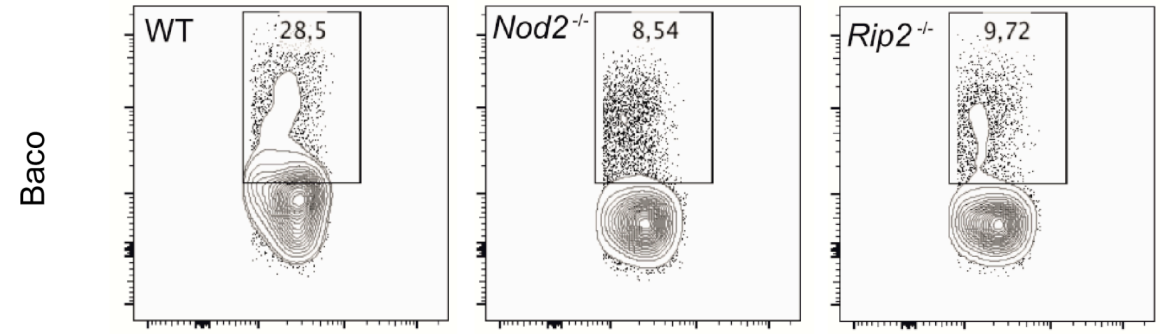

B
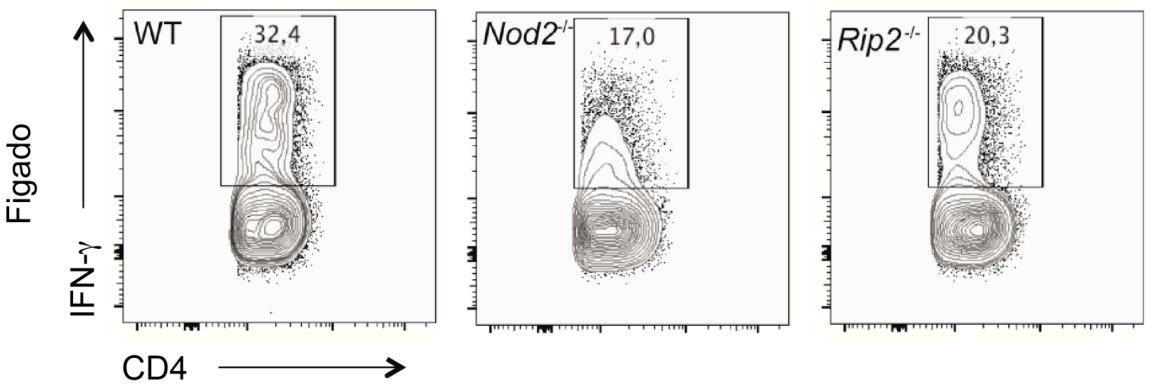

Figura 13: Células Th1 são induzidas pela via de NOD2-RIP2. Camundongos WT, Nod2 ${ }^{-/}$e Rip $2^{-/}$foram infectados com $10^{7}$ parasitos em fase estacionária de crescimento. Após 4 semanas de infecção o baço (A) e o fígado (B) foram coletados. As células foram estimuladas com PMA e ionomicina por $4 \mathrm{~h}$ e então analisadas por citometria de fluxo quanto a produção de IFN- $\gamma$. As análises foram feitas dentro da população de linfócitos viáveis $\mathrm{CD}^{+}$. Os dados são representativos de 3 experimentos independentes com resultados semelhantes. $\mathrm{N}=4$ camundongos/ grupo.

\section{3 - A via de sinalização de NOD2-RIP2 possui papel extrínseco na modulação da polarização de linfócitos Th1 e Th17}

Tendo em vista o papel de NOD2 e RIP2 em modular a polarização de células Th1 e Th17, nosso próximo passo foi avaliar se esse efeito seria orquestrado devido a uma modulação direta no linfócito $\mathrm{T}$, ou de maneira indireta, via APC, por exemplo. Para responder essa pergunta, nós isolamos células $\mathrm{T} \mathrm{CD}^{+} \mathrm{CD}^{+}{ }^{+} \mathrm{B} 220^{-}$e células dendríticas $\mathrm{CD} 11 \mathrm{c}^{+} \mathrm{MHCII}^{+} \mathrm{CD} 3^{-}$do baço de camundongos naives e infectados e verificamos a expressão de RNAm para Nod2 e Rip2. Como esperado, a infecção aumentou a expressão de transcritos para Nod2 e Rip2 somente nas células dendríticas (Figs. 14A e B), sugerindo que NOD2 e RIP2, não sendo expressos na célula T, não teriam nenhum efeito direto na sua polarização. Para confirmar essa hipótese, nós 
isolamos células $\mathrm{T}$ naives $\mathrm{CD} 4^{+} \mathrm{CD} 62 \mathrm{~L}^{+} \mathrm{CD} 44^{-}$de camundongos WT, Nod2/- $\mathrm{e}$ Rip2 $2^{-/-}$e cultivamos em condições polarizantes para Th1 e Th17 in vitro. Após 7 dias de cultivo, as células dos animais $N o d 2^{-/-}$e Rip2 $2^{-/-}$foram capazes de se diferenciar em Th1 (Fig. 14C) ou Th17 (Fig. 14D) de maneira semelhante àquela executada por células WT. Esses dados excluíram o papel intrínseco da via de NOD2-RIP2 na modulação da polarização de linfócitos Th1 e Th17, e, além disso, indicaram que outras células que expressam NOD2 e RIP2 estariam atuando nessa modulação.

A
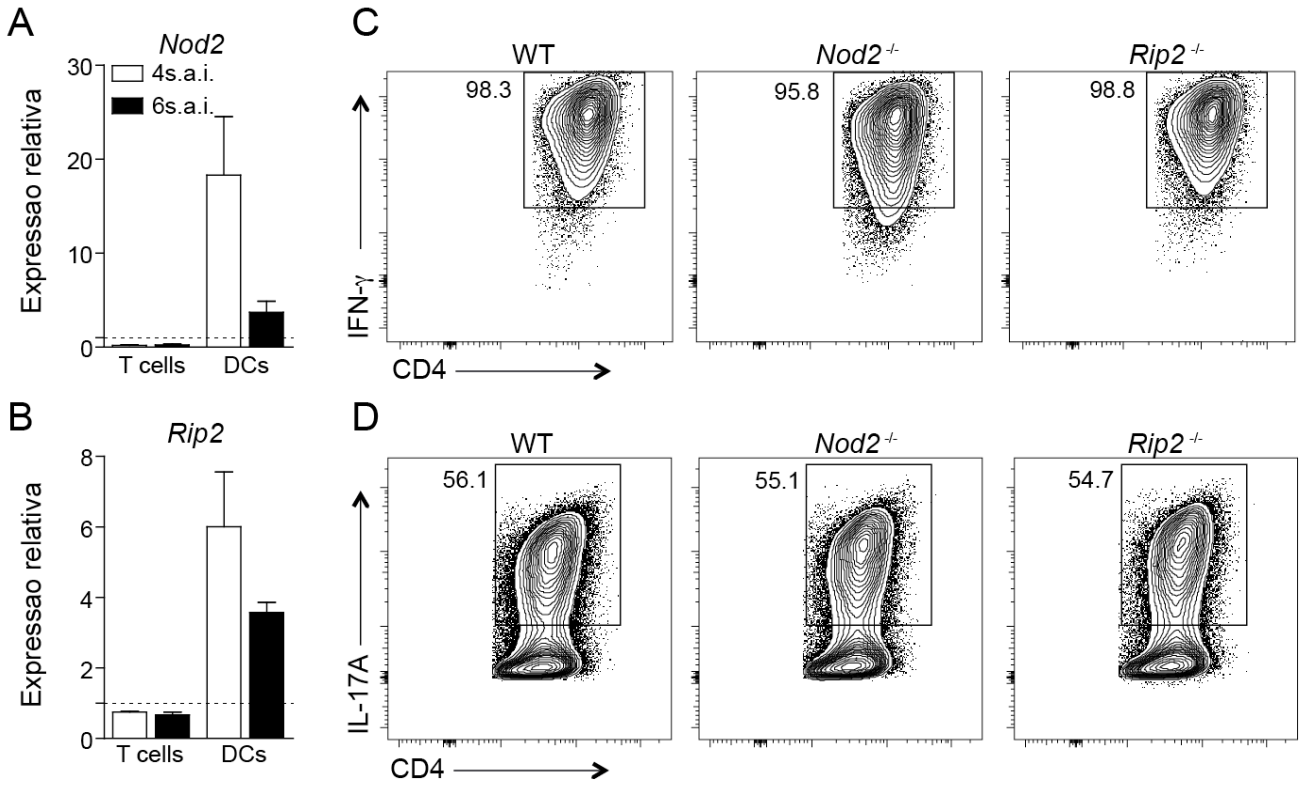

Figura 14: NOD2 e RIP2 não exercem papel intrínseco na diferenciação de linfócitos. Células $T$ $\mathrm{CD}^{+}{ }^{+} \mathrm{CD} 4{ }^{+} \mathrm{B} 220^{-}$e células dendríticas $\mathrm{CD} 1 \mathrm{c}^{+} \mathrm{MHCII}^{+} \mathrm{CD}^{-}$foram isoladas por sorting do baço de animais $\mathrm{WT}$ naives e infectados e analisados quanto a expressão de transcritos para Nod2 (A) e Rip2 (B) por PCR em tempo real. A linha tracejada representa a expressão dos transcritos em células oriundas de controles naives (A e B). Células T naives $\mathrm{CD}^{+} \mathrm{CD}_{2} \mathrm{~L}^{+} \mathrm{CD} 44^{-}$de camundongos WT, Nod2 $2^{-/-}$e Rip2 $2^{-/-}$foram isoladas por sorting e cultivadas na presença de $25 \mathrm{U} / \mathrm{mL}$ de $r \mathrm{IL}-2 ; 5 \mathrm{ng} / \mathrm{mL}$ de $r \mathrm{IL}-12$ e $10 \mu \mathrm{g} / \mathrm{mL}$ de anti-IL-4 (C) ou $5 \mathrm{ng} / \mathrm{mL}$ de $r \mathrm{TGF}-\beta ; 20$ $\mathrm{ng} / \mathrm{mL}$ de $r$ IL-6; $20 \mathrm{ng} / \mathrm{mL}$ de $r \mathrm{IL}-1 \beta ; 50 \mathrm{ng} / \mathrm{mL}$ de $r \mathrm{IL}-23 ; 10 \mu \mathrm{g} / \mathrm{mL}$ de anti-IFN- $\gamma ; 10 \mu \mathrm{g} / \mathrm{mL}$ de anti-IL-2 e 10 $\mu \mathrm{g} / \mathrm{mL}$ de anti-IL-4 (D). A produção de IFN- $\gamma$ e IL-17A foi analisada por citometria de fluxo após 7 dias de cultura (C e D). Os dados são representativos de 3 experimentos independentes com resultados semelhantes. $\mathrm{N}=$ 3-4/grupo. 
Visto que as células dendríticas expressam NOD2 e RIP2, e são responsáveis pela polarização adequada de linfócitos T, nós supomos que essas seriam as células responsáveis pelo efeito da modulação de Th1 e Th17 observado após a infecção em animais $N o d 2^{-/-}$e Rip $2^{-/-}$. Para testar essa possibilidade, células dendríticas de animais WT, Nod2 $2^{-/-}$e $\operatorname{Rip}^{-/-}$foram infectadas com L. infantum por $6 \mathrm{~h}$ e então pulsadas com OVA por 45 min adicionais; essas células foram então cocultivadas com linfócitos $\mathrm{T} \mathrm{CD}^{+}$com $\mathrm{TCR}$ transgênico e específico para OVA (linfócitos OT-II). Esse protocolo garantiu que o linfócito WT encontrasse o antígeno ao qual ele é específico sendo apresentado por células dendríticas WT ou knockouts no contexto de peptídeo-MHC e na presença de moléculas coestimuladoras, promovendo sua proliferação. Além disso, a diferenciação do linfócito foi direcionada pelo microambiente modulado pela infecção por Leishmania na célula dendrítica. Nessas condições nós observamos que os linfócitos cocultivados com células dendríticas $\mathrm{Nod}^{-/-}$ou $\mathrm{Rip}^{{ }^{-/-}}$apresentaram uma clara deficiência em produzir IFN- $\gamma$, quando comparados com os linfócitos que ficaram em cultura com células dendríticas WT (Fig. 15A), entretanto, produziram mais IL-17A (Fig. 15B). Esses dados confirmam os achados in vivo e mostram que a expressão de NOD2 e RIP2 na célula dendrítica modula a diferenciação de linfócitos Th1 e Th17 durante a infecção por L. infantum. Inesperadamente, mesmo as células dendríticas $\mathrm{Nod}^{-/-}$e Rip2 $2^{-/-}$somente pulsadas com OVA, mas não infectadas, induziram mais Th17 e menos Th1, comparadas com WT (Figs. 15C e D), sugerindo que, a parte do antígeno, na ausência de NOD2 e RIP2 as células dendríticas já possuem uma maquinaria celular mais propensa para polarização de Th17, e não Th1. Controles não infectados e não pulsados com OVA são mostrados nas Figuras 15E e F. 
A

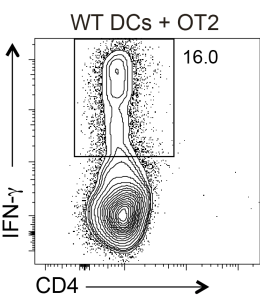

Nod2-'DCs + OT2

Rip2-'DCs + OT2
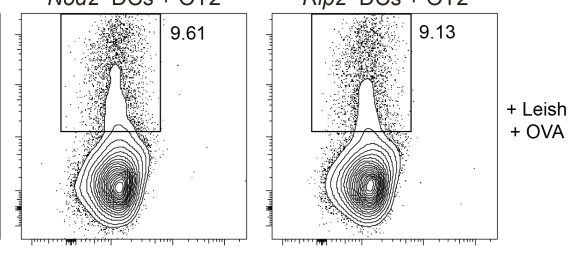

B

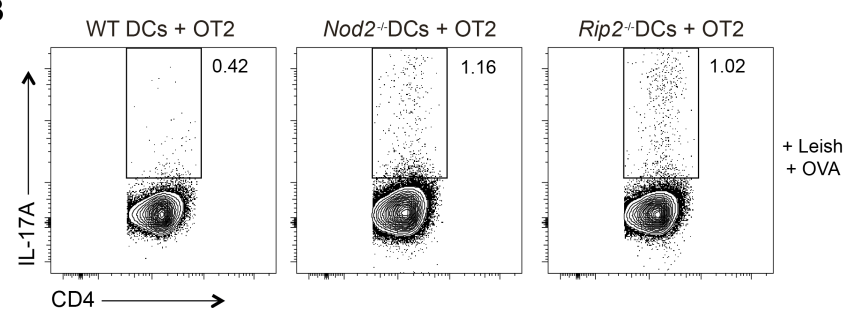

C

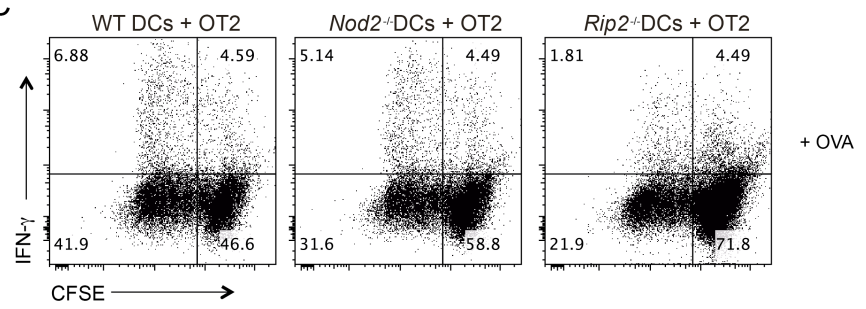

D
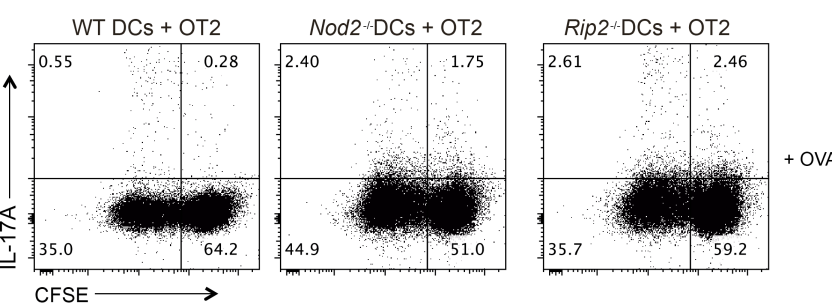

E
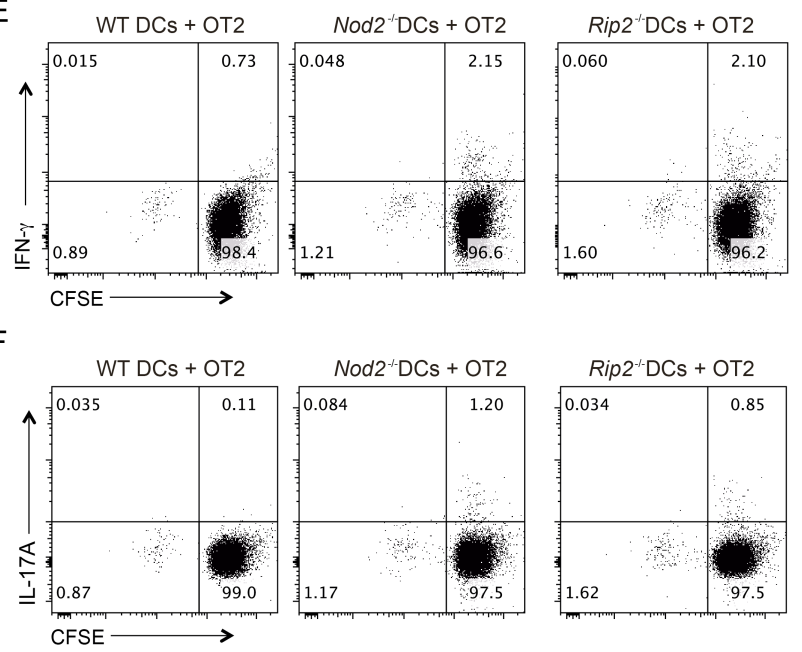

Figura 15: A expressão de NOD2 e RIP2 em células dendríticas modula a diferenciação de linfócitos T CD4 ${ }^{+}$. BMDCs de camundongos WT, Nod2 $2^{-/-}$e Rip $2^{-/-}$foram infectadas com L. infantum (5 parasitos: 1 célula) por 5 horas e então pulsadas com OVA $(100 \mu \mathrm{g} / \mathrm{mL})$ por $45 \mathrm{~min}$ adicionais (A e B); somente pulsados com OVA (C e D); ou mantidas inativadas (E e F). Linfócitos OT-II foram isolados por beads, adicionados aos poços (5 linfócitos: 1 BMDC) e mantidos em cocultura por 5 dias. A análise da produção de IFN- $\gamma$ e IL-17A foi feita por citometria de fluxo. Os dados são representativos de 3 experimentos independentes com resultados semelhantes realizados em quadruplicata. 
A ativação e diferenciação de linfócitos ocorre, normalmente, de maneira dependente de 3 sinais oriundos da célula dendrítica. O primeiro sinal é a apresentação antigênica no contexto de MHC, o segundo é a coestimulação por moléculas na superfície celular, e o terceiro são os sinais polarizantes mediados pelas citocinas liberadas no microambiente (Kapsenberg, 2003). Para entender o mecanismo pelo qual a via de NOD2-RIP2 na célula dendrítica modula a polarização de células Th1 e Th17, nós analisamos como esses 3 sinais funcionariam na ausência de NOD2 e RIP2. Como a cocultura foi realizada com BMDCs, nós checamos se a diferenciação dessas células ocorria de maneira semelhante em todos os grupos estudados. Após 7 dias de cultura de células da medula óssea sob condições de diferenciação em células dendríticas, a mesma porcentagem de células WT, Nod2 $2^{-/-}$e Rip $2^{-/-}$expressaram CD11c e MHC de classe II (Fig. 16), mostrando que a diferenciação das células dendríticas a partir de precursores da medula óssea ocorreu com a mesma eficiência na presença ou ausência de NOD2 e RIP2, e as alterações na quantidade de células Th1 e Th17 encontrados na cocultura não foi devido a diferenciação alterada das células dendríticas. Além disso, após infecção com Leishmania ou estímulo com LPS, a expressão de MHC de classe II e moléculas coestimuladoras, CD40 e CD86, foi alterada de maneira similar nas populações de cDCs $\left(\mathrm{CD} 11 \mathrm{c}^{+} \mathrm{MHCII}^{\mathrm{hi}} \mathrm{Ly}_{6 \mathrm{G}}^{-}\right)$e moDCs $\left(\mathrm{CD} 11 \mathrm{c}^{+} \mathrm{MHCII}^{\mathrm{int}} \mathrm{Ly}^{-} \mathrm{G}^{-}\right)$(Fig. 17A e B) e a frequência dessas populações também se mantive a mesma entre os grupos (Fig. 17C e D). 

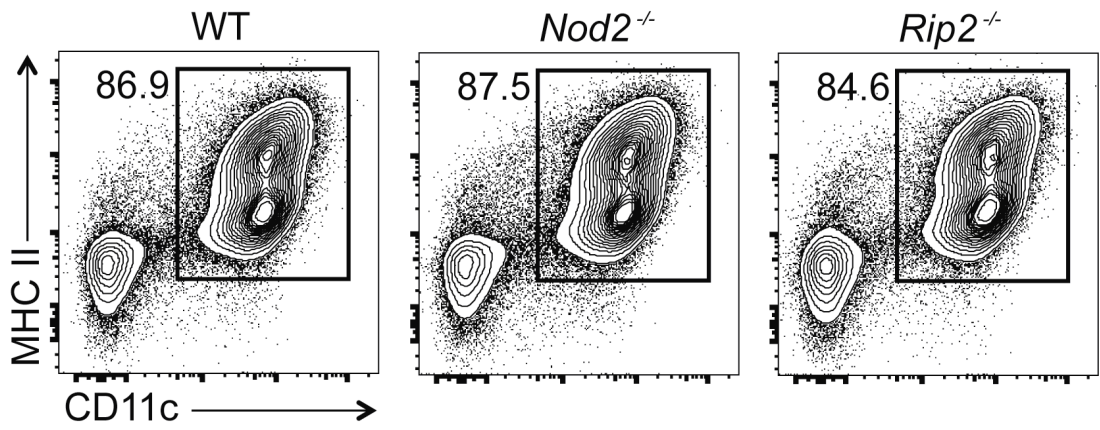

Figura 16: NOD2 e RIP2 não interferem na diferenciação de BMDCs. Células da medula óssea de camundongos WT, Nod2 $2^{-/}$e Rip $2^{-/-}$foram cultivadas por 7 dias na presença de GM-CSF e analisadas por citometria de fluxo quanto a sua capacidade de diferenciação em células dendríticas através da expressão de CD11c e MHC de classe II. Os dados são representativos de 5 experimentos independentes com resultados semelhantes. $\mathrm{N}=3$ /grupo.

Em relação a produção de citocinas, nós observamos que na ausência de NOD2 e RIP2 há um comprometimento significativo na expressão de RNAm para Il12p35, tanto por BMDCs infectadas quanto no fígado de animais infectados (Figs. 18A e B). Por outro lado, os níveis dos transcritos para Il12/23p40 em BMDCs e no fígado, foram aumentados nos knockouts em relação ao WT (Figs. 18A e B). Isso acarretou a diminuição nos níveis de IL-12p70 (heterodímero formado pelas subunidades IL-12p35 e IL-12/23p40; Fig. 18C) e aumento de IL12/23p40 (Fig. 18D) detectados no sobrenadante das BMDCs Nod2 $2^{-/}$e Rip2 $2^{-/-}$infectadas com $L$. infantum, comparado aos níveis encontrados no sobrenadante das culturas WT. Como a IL12/23p40 é uma subunidade compartilhada entre as citocinas IL-12 e IL-23, o fato de Il12p35 ser regulado negativamente na ausência de NOD2 e RIP2, mas Il23p19 ser mantido (Figs. 18A e B), isso favoreceu o aumento de IL-23 (heterodímero formado pelas subunidades IL-12/23p40 e IL-23p19) no sobrenadante de BMDCs $\mathrm{Nod}^{2 /-}$ e Rip $^{-/-}$comparado ao WT (Fig. 18E). O aumento da oferta de IL-23 concomitantemente com a diminuição de IL-12p70 favorece a polarização de linfócitos Th17, porém, dificulta a diferenciação Th1, fenótipo encontrado nos animais $\mathrm{Nod}^{-/-}$e Rip2 $2^{-/}$. Outras citocinas envolvidas na polarização de células Th17, como Illb, 
$T g f b$ e Il6 não foram alteradas significativamente nos animais knockouts comparados aos WT

\author{
(Figs. 18A e B).
}

A

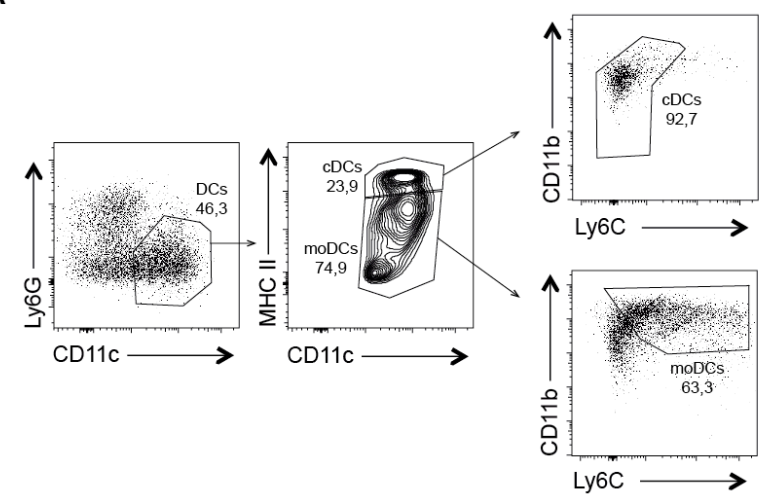

B
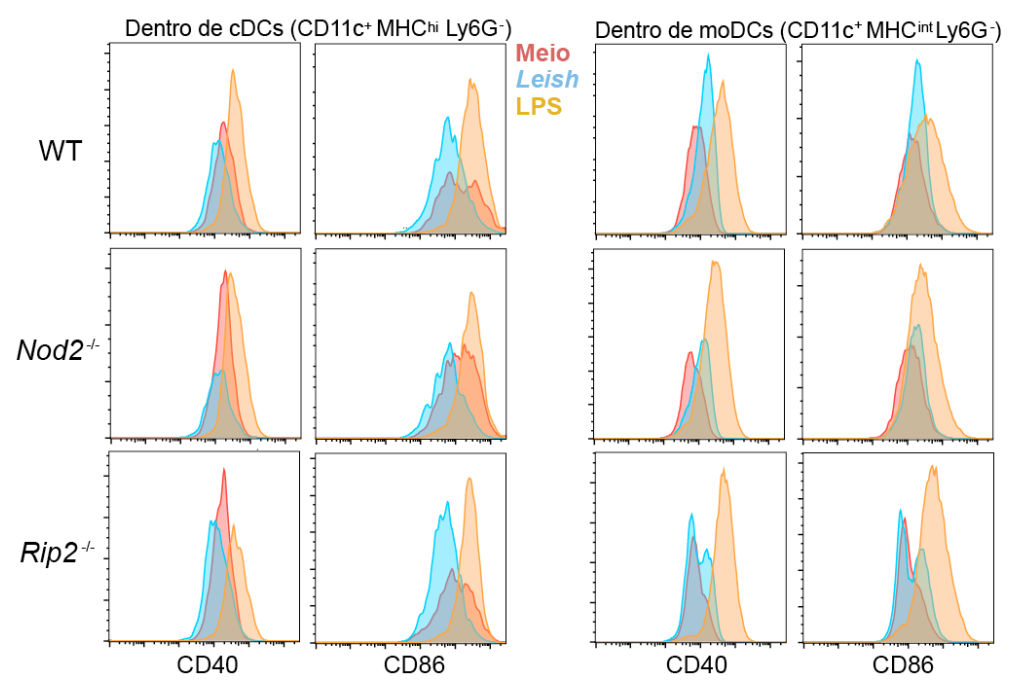

C

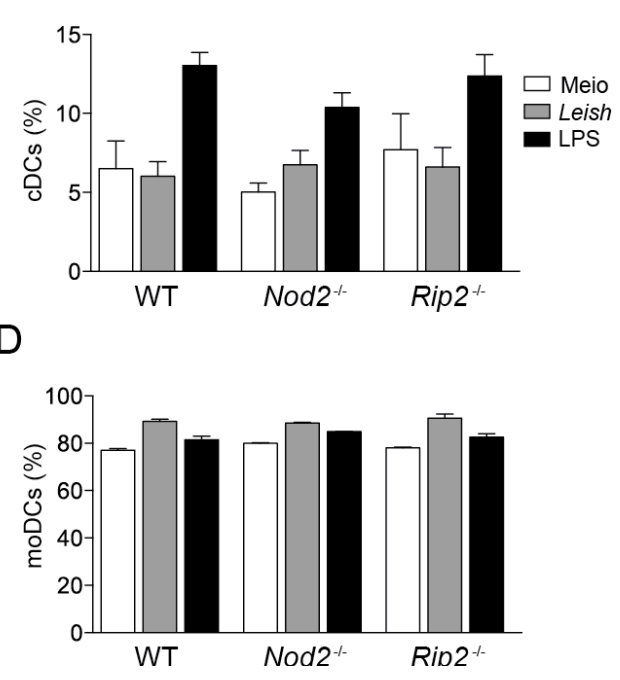

Figura 17: A ausência de NOD2 e RIP2 não compromete a capacidade de ativação das BMDCs. Células da medula óssea de camundongos WT, Nod2 $2^{-/}$e Rip $2^{-/}$foram cultivadas por 7 dias na presença de GM-CSF para

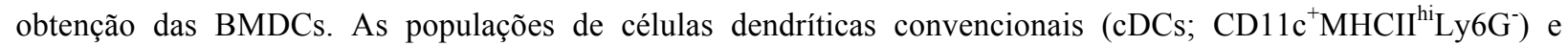
monocíticas (moDCs; $\mathrm{CD} 11 \mathrm{c}^{+} \mathrm{MHCII}{ }^{\text {int }}{ }^{\mathrm{Ly}} 6 \mathrm{G}^{-}$) foram definidas de acordo com as estratégias de gates mostradas em A. A expressão de CD40 e CD86 nos controles negativos (histograma vermelho), após $24 \mathrm{~h}$ de infecção com $L$. infantum (histograma azul) ou estimuladas com LPS (200 $\mathrm{ng} / \mathrm{mL}$; histograma laranja) foi analisada por citometria de fluxo dentro nas populações de cDC e moDC (B). Porcentagem das populações de cDC (C) e moDC (D) em BMDCs WT, Nod2 ${ }^{-/}$e Rip2 $2^{-/}$não estimuladas (meio, barras brancas), infectadas (barras cinzas) ou estimuladas com LPS (barras pretas). Esses resultados são representativos de 4 experimentos independentes com resultados semelhantes realizado em triplicata. 
A

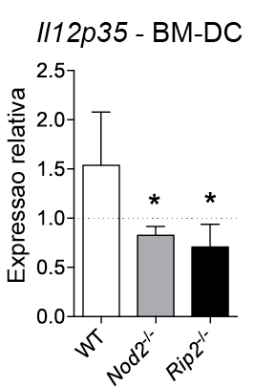

II23p19 - BM-DC

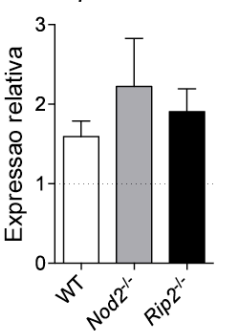

$1 / 6$ - BM-DC

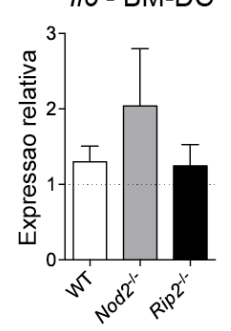

B

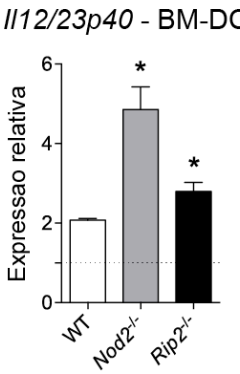

II1b - BM-DC
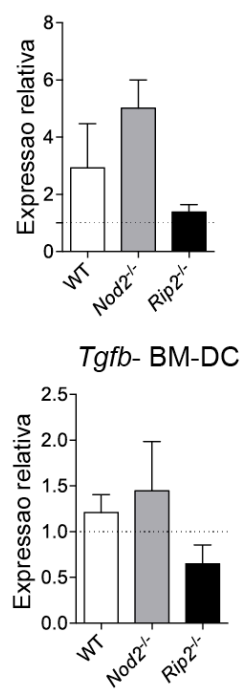
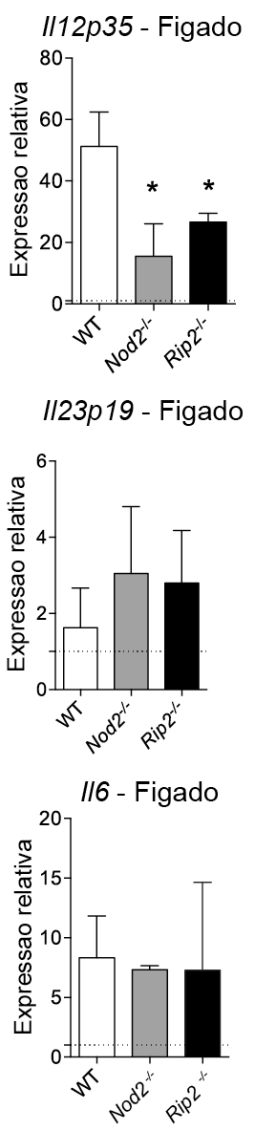

II12/23p40 - Figado
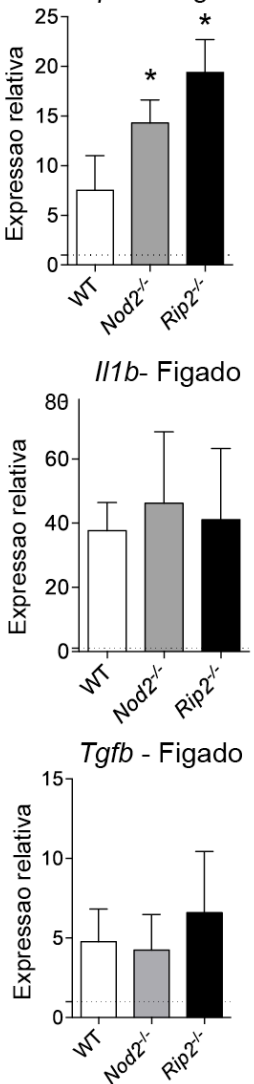

C
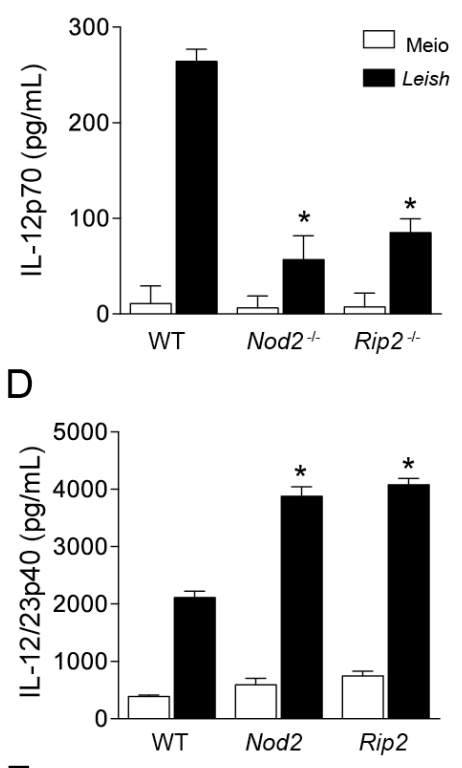

$E$

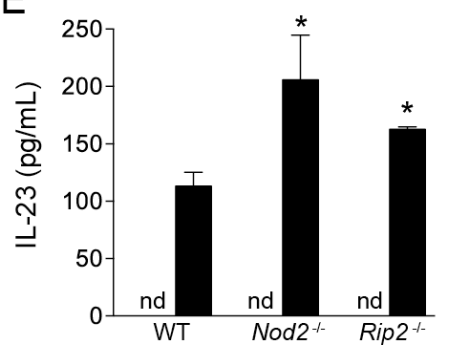

Figura 18: NOD2 e RIP2 induzem a produção de IL-12p35 e IL-12p70 mas inibem a produção de IL12/23p40 e IL-23 em células dendríticas infectadas com $L$. infantum. Células da medula óssea de camundongos WT, Nod2 $^{-/}$e Rip $2^{-/}$foram cultivadas por 7 dias na presença de GM-CSF para obtenção das BMDCs. Após $6 \mathrm{~h}$ de infecção com $L$. infantum as células foram coletadas e analisadas por PCR em tempo real quanto a expressão de

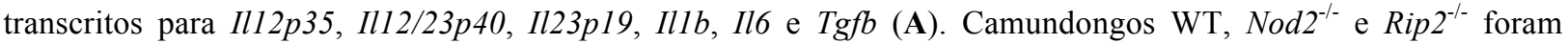
infectados com $10^{7}$ parasitos em fase estacionária de crescimento. Após 4 semanas de infecção os animais foram sacrificados e tiveram o fígado coletado para análises por PCR em tempo real (B). As linhas tracejadas indicam a expressão dos transcritos em células ou camundongos controles não infectados (A e B). A produção de IL-12p70 (C), IL-12/23p40 (D) e IL-23 (E) no sobrenadante de BMDC não infectadas (barras brancas) e infectadas (5 parasitos: 1 célula; barras pretas) foi quantificada por ELISA após $24 \mathrm{~h}$ de infecção. Esses resultados são representativos de 2-3 experimentos independentes com resultados semelhantes, realizado em quadruplicata. ${ }^{*}, \mathrm{p}<$ 0,05 . nd, não detectado. 
A sinalização via NOD2-RIP2 está relacionada com a produção de citocinas através da ativação da via das MAPKs (Chen et al., 2009). De fato, nós encontramos uma acentuada redução na fosforilação de p38 e JNK após a infecção de BMDCs oriundas de animais $N o d 2^{-/-}$e Rip $2^{-/}$, comparado ao grupo WT (Figs. 19A e B). Todavia, nenhuma alteração foi observada na fosforilação de ERK1/ERK2 (Fig. 19C). Esses resultados sugerem que na ausência da sinalização da via de NOD2-RIP2, a fosforilação de p38 e JNK são defeituosas, o que diminui a produção de IL-12, levando a uma redução da resposta Th1. Por outro lado, outras vias garantem altos níveis de IL-12/23p40, garantindo a oferta de IL-23 e certificando a polarização de células Th17.

A

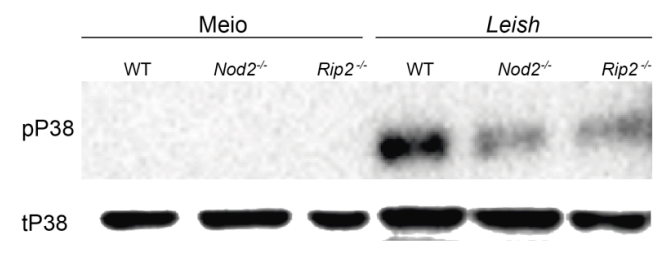

B

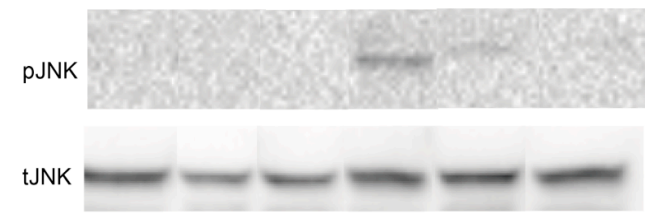

C

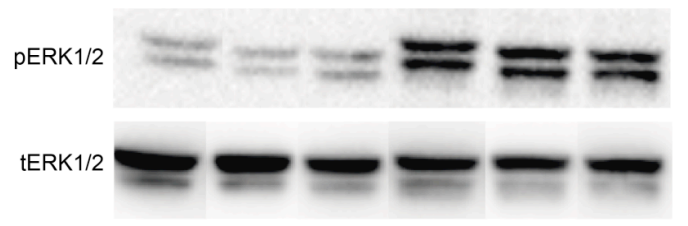

Figura 19: A fosforilação de p38 e JNK são prejudicadas na ausência de NOD2 e RIP2. Células da medula óssea de camundongos WT, $\operatorname{Nod}_{2}{ }^{-/}$e Rip $2^{-/-}$foram cultivadas por 7 dias na presença de GM-CSF para obtenção das BMDCs. Após 30 min de infecção (5 parasitos:1 célula) as BMDCs foram coletadas em inibidor de proteases e fosfatases e analisadas por western blot quanto à fosforilação de p38 (A), JNK (B) e ERK1/ERK2 (C). A intensidade das bandas são indicativos da quantidade de proteína total (t) ou fosforilada (p) em cada amostra. Os resultados são representativos de 2 experimentos com resultados semelhantes realizados em triplicata. 


\section{4 - Células dendríticas CD8 $\alpha \alpha^{+}$são importantes para polarização de células Th1, mas não de linfócitos Th17 durante a infecção por L. infantum}

Diferentes populações de células dendríticas tem sido associado com a indução de diferentes subtipos de células T. Já é descrito que as duas populações de células dendríticas do baço, $\mathrm{CD}^{+} 33 \mathrm{D} 1^{+}$e $\mathrm{CD} 8 \alpha \alpha^{+} \mathrm{XCR} 1^{+}$, expressam Nod2 e Rip2 (Fig. 20A e B, retirado de http://www.immgen.org), mas dados da literatura mostram que as dendríticas $\mathrm{CD} 8 \alpha \alpha^{+} \mathrm{XCR} 1^{+}$ compõem a principal fonte de IL-12 durante a LC, sendo uma população chave para a diferenciação de células Th1 nessa doença (Ashok et al., 2014; Martinez-Lopez et al., 2015). Além disso, existem trabalhos que mostram que células dendríticas $\mathrm{CD}^{+}$são responsáveis pela polarização de células Th17 (Persson et al., 2013; Schlitzer et al., 2013). Para entender se os animais $N o d 2^{-/-}$e Rip $2^{-/-}$possuem alguma alteração nessas populações de células dendríticas que poderia corroborar com o fenótipo de diminuição de Th1 e aumento de Th17 observado, nós coletamos o baço de camundongos WT, Nod2 $2^{-/-}$e Rip $2^{-/-}$e analisamos as células dendríticas por imunofluorescência e citometria de fluxo. Foi observado que os camundongos knockouts naives ou após 4 semanas de infecção possuem quantidades comparáveis de células dendríticas $\mathrm{CD}^{+} 33 \mathrm{D} 1^{+}$e $\mathrm{CD} 8 \alpha \alpha^{+} \mathrm{XCR} 1^{+}$que também são distribuídas normalmente nas regiões de bridging channels $\left(\mathrm{CD}^{+} 33 \mathrm{D} 1^{+}\right)$e espalhados nas polpas vermelha e branca $\left(\mathrm{CD} 8 \alpha \alpha^{+} \mathrm{XCR} 1^{+}\right)$ (Fig. 21A e B). Além disso, nós vimos que a Leishmania infecta bem as 3 populações de células dendríticas do baço, $\mathrm{CD}^{+} 33 \mathrm{D} 1^{+}, \mathrm{CD} 8 \alpha \alpha^{+} \mathrm{XCR}^{+}$e $\mathrm{CD} 4^{-} \mathrm{CD} 8^{-}$(Fig. 21C). Esses dados mostram que o aumento de Th17 e a diminuição de Th1 observado na ausência de NOD2 e RIP2 não é influenciado por um desbalanço nas populações de células dendríticas ou porque a Leishmania infectaria preferencialmente uma população específica de células dendríticas.

O desenvolvimento das células dendríticas $\mathrm{CD} 8 \alpha^{+} \mathrm{XCR}^{+}$é dependente do fator de transcrição Batf3 e, portanto, animais Batf $^{-/-}$não possuem células dendríticas $\mathrm{CD} 8 \alpha \alpha^{+} \mathrm{XCR} 1^{+}$ 
(Fig. 22A). Como esperado, esses animais possuem redução em células Th1 após infecção por L. infantum, de 10,5\% (WT) para 4,36\% $\left(\right.$ Batf $\left.^{-/-}\right)$, mas as células Th17 foram aumentadas (Fig. 22B), fenótipo semelhante ao encontrado nos animais $N o d 2^{-/-}$e Rip $2^{-/-}$. Além disso, assim como os camundongos $\mathrm{Nod}^{-/-}$e Rip $2^{-/-}$, os animais Batf3 $3^{-/-}$foram mais suscetíveis a infecção (Fig. 22C). Juntos, esses dados sugerem que durante a infecção por L. infantum, a expressão de NOD2 e RIP2 em células dendríticas CD8 $\alpha \alpha^{+} \mathrm{XCR}^{+}$é importante para a produção de IL-12 e polarização de células Th1, mas não de linfócitos Th17. 
A

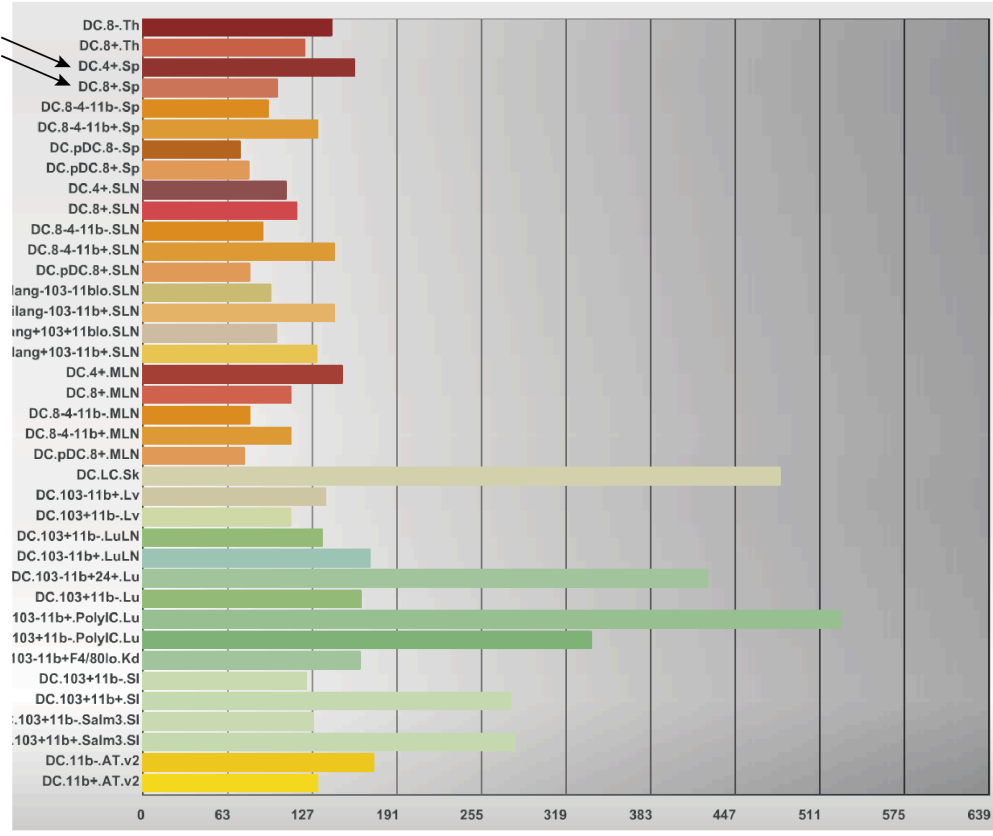

\begin{tabular}{|c|c|c|}
\hline Probe Set: & 10573790 & \multirow[b]{2}{*}{$\begin{array}{l}\text { Same Gene in } \\
\text { Other Datagroup }\end{array}$} \\
\hline Gene Symbol: & Nod2 & \\
\hline Title: & \multicolumn{2}{|c|}{ nucleotide-binding oligomerization dom } \\
\hline Aliases: & \multicolumn{2}{|c|}{ ACUG /// BLAU /// CARD15 /// CD /// IBD1 } \\
\hline Chromosome: & \multicolumn{2}{|l|}{8} \\
\hline Location: & \multicolumn{2}{|l|}{91171245} \\
\hline NCBI: & \multicolumn{2}{|l|}{257632} \\
\hline Unigene: & \multicolumn{2}{|c|}{ Mm.222633 } \\
\hline Ensembl: & \\
\hline KEGG: & \\
\hline GO: & \multicolumn{2}{|c|}{$\begin{array}{l}\text { nucleotide binding (166) } \\
\text { innate immune response in mucosa (2227) } \\
\text { activation of immune response (2253) }\end{array}$} \\
\hline $\begin{array}{l}\text { SignatureDB: } \\
\text { (human only) }\end{array}$ & \multicolumn{2}{|c|}{ SignatureDB (257632) } \\
\hline
\end{tabular}

B

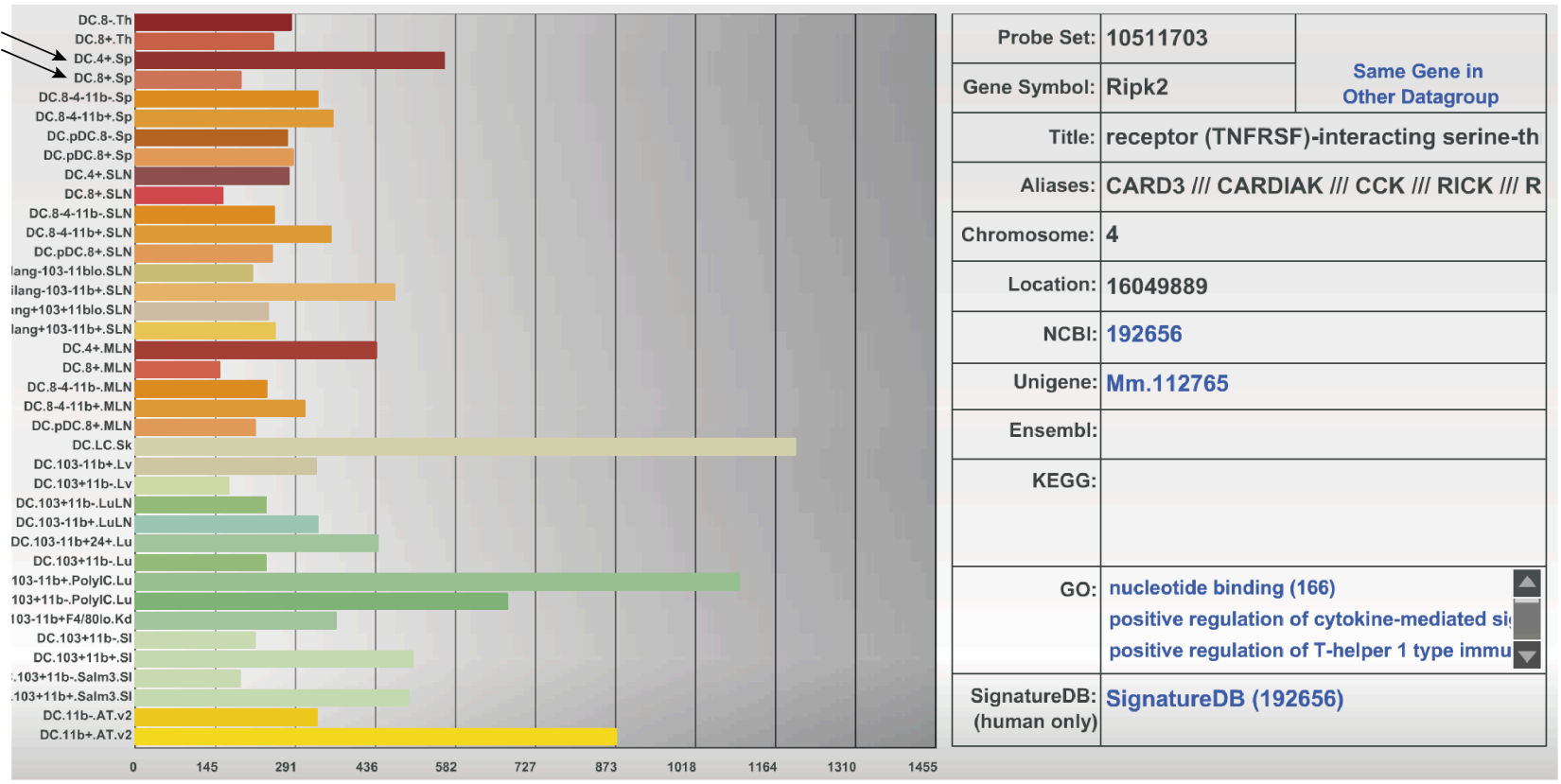

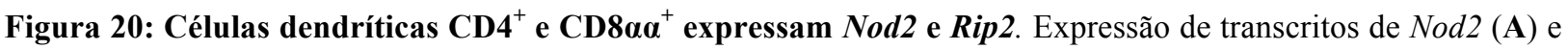
Rip2 (B) nas diferentes populações de células dendríticas. Imagem retirada de http://www.immgen.org. As setas indicam as células dendríticas $\mathrm{CD}^{+}$e $\mathrm{CD} 8 \alpha \alpha^{+}$do baço. 
A
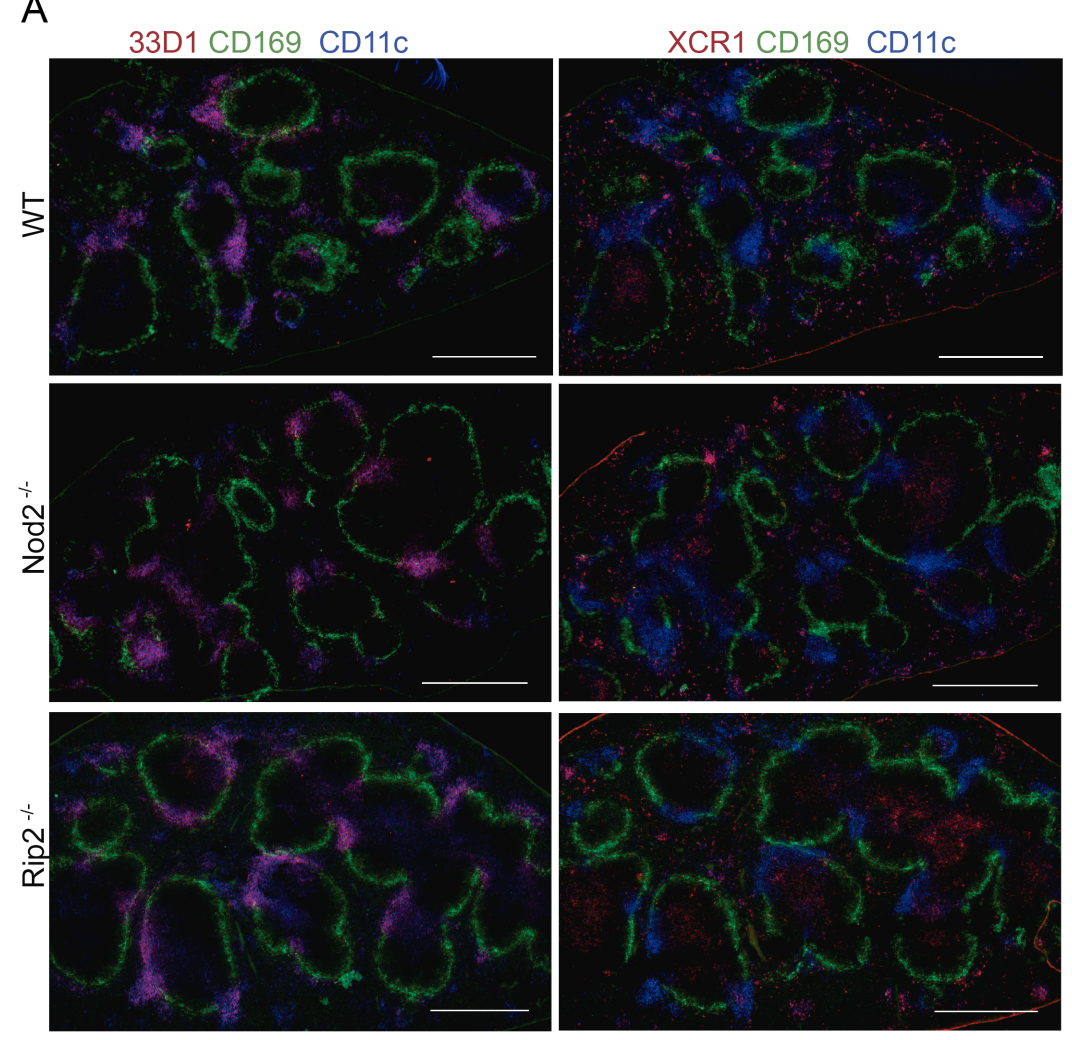

B
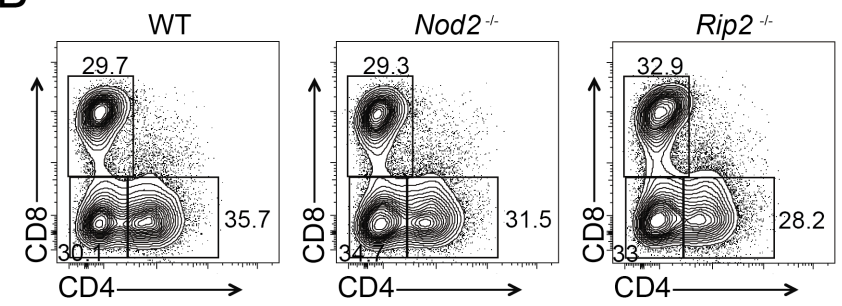

C
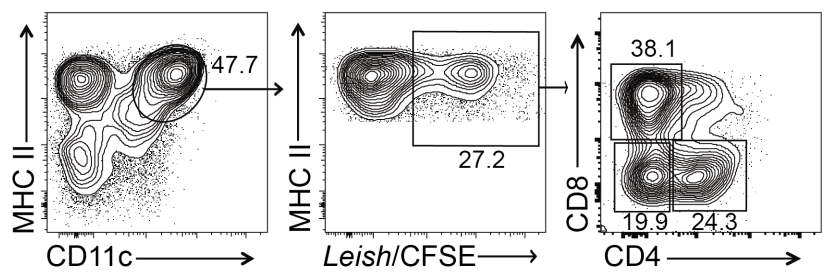

Figura 21: Camundongos $\mathrm{Nod}^{-/-}$e Rip $2^{-/-}$apresentam as populações de células dendríticas $\mathrm{CD}^{+}{ }^{33 D} 1^{+}$e

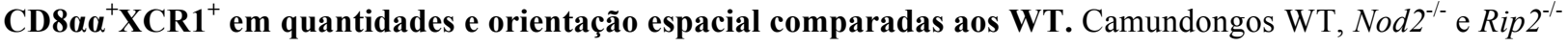
naives tiveram os baços coletados e analisados por imunofluorescência. 33D1 (painel da esquerda; em vermelho), XCR1 (painel da direita; em vermelho), CD169 (verde) e CD11c (azul) foram marcados. Os resultados são mostrados em intensidade de fluorescência. Escala $=500 \mu \mathrm{m}(\mathbf{A})$. Camundongos WT, Nod2 $2^{-/}$e Rip $2^{-/}$foram infectados com $10^{7}$ parasitos em fase estacionária de crescimento. Após 4 semanas de infecção os baços foram coletados e as populações de células dendríticas foram analisadas por citometria de fluxo. As populações mostradas são CD11 c ${ }^{+} \mathrm{MHCII}^{+} \mathrm{TCR} \beta^{-}$(B). Células dendríticas do baço foram enriquecidas por seleção por beads e infectadas com Leishmania marcadas com CFSE. Depois de $2 \mathrm{~h}$ as células foram adquiridas no citômetro para análise das populações infectadas (C). Os dados são representativos de 3 experimentos independentes com resultados semelhantes. $\mathrm{N}=3$. 
A
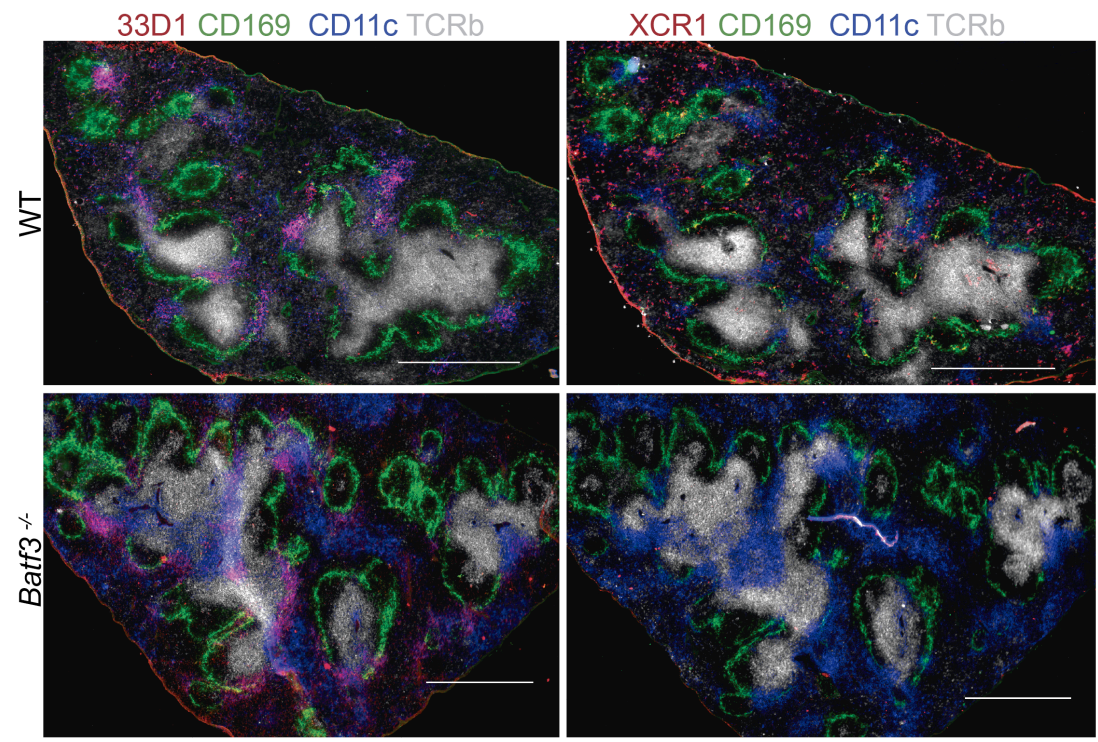

B
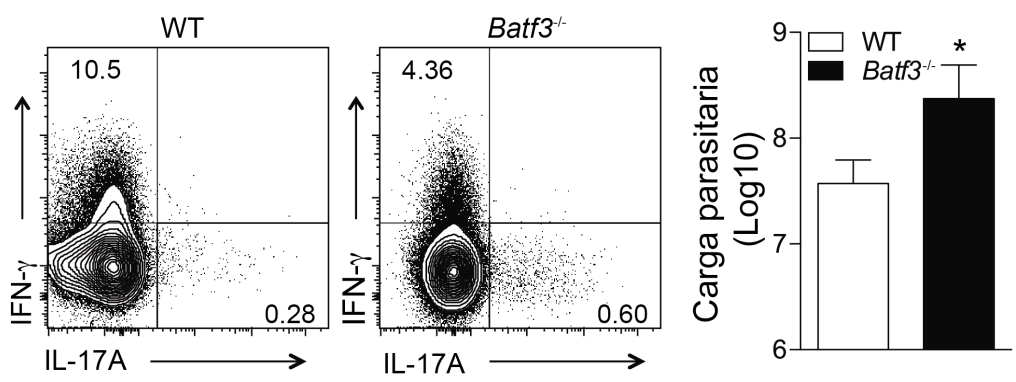

Figura 22: Camundongos Batf $^{-/-}$possuem menos células Th1 e mais células Th17 após infecção com $L$. infantum. Camundongos WT e Batf $3^{-/-}$naives tiveram os baços coletados e analisados por imunofluorescência. 33D1 (painel da esquerda; em vermelho), XCR1 (painel da direita; em vermelho), CD169 (verde), CD11c (azul) e TCR $\beta$ (branco) foram marcados. Os resultados são mostrados em intensidade de fluorescência. Escala $=500 \mu \mathrm{m}$ (A). Camundongos WT e Batf $3^{-/-}$foram infectados com $10^{7}$ parasitos em fase estacionária de crescimento. Após 4 semanas de infecção os baços foram coletados e as células foram estimuladas com PMA e ionomicina por $4 \mathrm{~h}$, quando então foram analisadas por citometria de fluxo. A análise da produção de IFN- $\gamma$ e IL-17A foi realizado dentro da população TCR $\beta^{+} \mathrm{CD}^{+}(\mathbf{B})$. A carga parasitária do baço foi feita através da técnica de diluição limitante (C). $\mathrm{N}=3-4$ camundongos/grupo. Representativo de 3 experimentos independentes com resultados semelhantes. *, $\mathrm{p}<0,05$. 
V. Discussão 
Durante uma infecção, a geração de uma resposta imunológica adequada é um ponto crítico que irá distinguir se o hospedeiro irá desenvolver os sintomas clássicos da doença (susceptibilidade), progredir para cura (resistência), ou, ainda, um padrão assintomático da infecção (tolerância) (Iwasaki e Pillai, 2014). Embora os fenômenos que ocorrem na infecção ou doença causadas por parasitos do gênero Leishmania sejam altamente complexos, muitos avanços no entendimento da sua biologia tem sido feito nos últimos anos (Kaye e Scott, 2011). O sequenciamento do genoma de diversas espécies de Leishmania (Peacock et al., 2007), as análises pós-genômica (Kaye e Blackwell, 2008), o estudo das interações com o inseto vetor (Dobson et al., 2010; Sadlova et al., 2010), e a melhor compreensão da imunologia e da biologia celular das interações entre o parasito e diversos hospedeiros são exemplos de pesquisas que tem auxiliado a solidificar esse conhecimento. Nesse trabalho, nós buscamos entender um dos caminhos que o sistema imune inato, através de seus receptores de reconhecimento de padrão, usa para detectar a infecção e ativar o sistema imune adaptativo, promovendo o elo entre essas duas respostas.

O conhecimento de que os parasitos do gênero Leishmania induzem um padrão de citocinas pró-inflamatórias relacionadas ao perfil Th1, como IL-12, TNF- $\alpha$ e IFN- $\gamma$, por macrófagos e outras células do sistema imunológico já é bem consolidado (Wilson et al., 2005; Liese et al., 2008). Outra população de linfócitos pró-inflamatórios conhecida por ter papel importante em algumas infecções intracelulares é o perfil Th17 (Van, 2009). A diferenciação desse padrão efetor requer a presença das citocinas IL-1 $\beta$, TGF- $\beta$, IL-6 e IL-23 no microambiente inflamatório, que leva a expressão do fator de transcrição ROR $\gamma \mathrm{t}$ no linfócito (Ivanov et al., 2006), e a expressão da sua citocina característica, a IL-17A, dentre outras (Volpe et al., 2008). Nosso grupo, e também outros pesquisadores, mostramos previamente que a infecção por parasitos do gênero Leishmania induz a produção de IL-17A em pacientes e camundongos, sendo que o seu papel e a sua fonte celular variam de acordo com a espécie do 
parasito. A análise de dados gerados a partir do RNAseq, tecnologia de sequenciamento utilizada para determinação de sequências e abundância de RNAs mensageiros e não codificantes, nos permitiu constatar que transcritos relacionados com a resposta Th17 são suprimidos em pacientes com LV, e que o tratamento não altera esse padrão. Essa metodologia constitui uma nova abordagem para o estudo quantitativo de transcriptomas, sendo que o nosso grupo vem trabalhando para ampliar essas análises e enriquecer o conhecimento acerca da resposta imune nos diferentes perfis sintomatológicos apresentados por indivíduos infectados por L. infantum. Nesse sentido, Maretti-Mira e colaboradores realizaram RNAseq de lesões cutâneas primárias de pacientes com LC por L. braziliensis que evoluíram ou não para um quadro de leishmaniose mucocutânea. Este estudo destaca que pacientes com LC localizada apresentam um perfil de resposta imune mais efetivo contra o parasito, com aumento da transcrição de genes envolvidos com a quimioatração de células da imunidade inata, bem como de genes relacionados à apresentação de antígeno, em relação aos pacientes que evoluem para o quadro de leishmaniose mucocutânea (Maretti-Mira et al., 2012).

Com o objetivo de investigar o mecanismo pelo qual a imunidade adaptativa, em especial os linfócitos Th1 e Th17, são modulados na LV, nós partimos para experimentos em modelo murino. Os dados demonstraram que células $\mathrm{B} \mathrm{CD} 19^{+}$constituem uma fonte celular importante de IL-17A, enquanto que a sua produção por linfócitos Th17, células NK, linfócitos $\mathrm{TCD}^{+}$ou $\mathrm{T} \gamma \delta$ é muito baixa ou praticamente inexistente. $\mathrm{O}$ mesmo é visto na infecção pelo $T$. cruzi, que também possui células B como a principal população produtora de IL-17A, que ocorre de maneira independente das citocinas IL-6 e IL-23 e dos fatores de transcrição ROR $\gamma$ t e AhR, mas sim através de mecanismos dependentes da trans-sialidase do parasito (Bermejo et al., 2013). Células B produtoras de IL-17A também foram descritas em pacientes com artrite reumatoide (Schlegel et al., 2013). Durante a infecção por L. infantum, a IL-17A possui papel protetor, uma vez que ela potencializa a produção de NO induzida por IFN- $\gamma$ em macrófagos 
infectados, aumentando a capacidade leishmanicida dessas células (Nascimento et al., 2015). Na infecção por L. donovani, todavia, esse papel é controverso, uma vez que existem trabalhos que relacionam IL-17A e IL-22 com proteção em indivíduos assintomáticos (Pitta et al., 2009), ou ainda outros que mostram que o tratamento com curdlan induz as citocinas IL-6, IL-1 $\beta$, IL-23, IL-17A e IL-22, e que, via indução de NO, também exercem proteção em modelo experimental (Ghosh et al., 2013). Porém, outros artigos apontam que na ausência de IL-17A os camundongos são mais resistentes à infecção por L. donovani. Nesse modelo, a produção de IL-17A seria de responsabilidade de células $T \gamma \delta$ (Sheel et al., 2015; Terrazas et al., 2015). Durante a infecção por L. braziliensis, agente causador da LC, a IL-17A produzida por células T CD4 ${ }^{+}$está relacionada com a proteção do hospedeiro infectado (Vargas-Inchaustegui et al., 2008). A infecção por L. major, contudo, induz células T $\mathrm{CD}^{+}$e neutrófilos produtores de IL-17A, a qual possui um efeito supressor da resposta e indutor de suscetibilidade (Lopez Kostka et al., 2009). Em nosso modelo, entretanto, não observamos indução de células Th17, mas sim uma modulação negativa na expressão de transcritos para Rorgt, ao passo que Tbx21, Ifng e Il17a foram induzidos. Com essa descoberta, focamos então em experimentos para entender como se daria a modulação positiva de Th1 e negativa de Th17 durante a infecção por L. infantum.

O processo de diferenciação de um subtipo de linfócito $\mathrm{T} \mathrm{CD}^{+}$é altamente dependente da ação coordenada de fatores que podem atuar como agonistas ou antagonistas daquele processo. Dependendo desse balanço de prós e contras, os linfócitos podem ser programados ou ainda reprogramados depois de já diferenciados. Em virtude do perfil Th17 ser o mais inflamatório já descrito, poder atuar como protetor em algumas infecções, mas ser patogênico em doenças autoimunes e doenças inflamatórias crônicas, por exemplo, ou ainda poder ser convertido em outro subtipo celular; vários grupos tem focado seus esforços em descrever os reguladores da via de diferenciação, manutenção, ou ainda reprogramação de células Th17 patogênicas, por exemplo (Yosef et al., 2013). Alguns dos reguladores já descritos são: IL-6, IL- 
1 $\beta$, TGF- $\beta$, IL23, ROR $\gamma$ t, CCR6, Fos12, STAT3, IRF4, BATF, IкB\}, c-Maf, Runx1, AhR, NOD2 (Brustle et al., 2007; Yang et al., 2007; Veldhoen et al., 2008; Zhang et al., 2008; Bauquet et al., 2009; Schraml et al., 2009; Okamoto et al., 2010; Brain et al., 2013). Nossos experimentos mostraram que após a infecção experimental com $L$. infantum, existem reguladores de Th17 que são induzidos, como Stat3 e $I l 1 b$, porém, outros são inibidos, como Il23, Rorc e Ccr6. Também foi detectado que a infecção induziu a expressão de Nod2 e Rip2 em células dendríticas, mas não em linfócitos T, já que NOD2 tem a sua expressão restrita a fagócitos como macrófagos, células dendríticas, células de Paneth (Ogura et al., 2001; Ogura et al., 2003; Tada et al., 2005) e algumas poucas células epiteliais (Hisamatsu et al., 2003; Uehara et al., 2007). Outros patógenos como bactérias gram+ ou gram- e o parasito T. gondii também induzem a expressão de NOD2 (Shaw et al., 2009; Caruso et al., 2014).

O papel dos TLRs em modular a resposta imune adaptativa via alteração das atividades da célula dendrítica já é bem estudado, enquanto que o papel dos NLRs na imunidade adaptativa é menos entendido (Liu et al., 2013). Nossos dados mostraram que camundongos deficientes para NOD2 e RIP2, uma vez infectados, induzem uma resposta Th17 mais potente do que aquela detectada em animais WT, indicando que essas proteínas possuem efeito inibidor da diferenciação de células Th17. O papel da via de NOD2 na modulação negativa de linfócitos Th17 vem sendo descrito (Brain et al., 2013). Em desordens inflamatórias intestinais, como na doença de Crohn, ou também na toxoplasmose ocular, o polimorfismo com perda de função no gene de Nod2 é associado com a forte indução da resposta Th17 e o desenvolvimento de sintomas característicos dessas doenças (Bonen et al., 2003; Economou et al., 2004; Franke et al., 2010; Dutra et al., 2013). Considerando outros NLRs, em modelo de Mycobacterium tuberculosis morta pelo calor e adjuvante completo de Freund, Shenderov e colaboradores demonstraram uma grande redução na diferenciação de células Th17 em camundongos deficientes para ASC e Caspase-1, o que foi causado devido a deficiência na síntese de IL-1 $\beta$ 
(Shenderov et al., 2013). Na ausência de ASC e/ou NLRP3, camundongos infectados com Schistosoma mansoni falham em induzir células Th1, Th2 e Th17 (Ritter et al., 2010), ou ainda, infectados com Candida albicans ou Helicobacter pylori também apresentam diminuição nas respostas Th1 e Th17 (Van De Veerdonk et al., 2011; Hitzler et al., 2012). Por outro lado, existem trabalhos que demonstram que a estimulação de NOD1 e NOD2 levaria a diferenciação de células Th1 e Th17 (Fritz et al., 2007; Van Beelen et al., 2007). Isso nos faz acreditar que a modulação da resposta imune adaptativa via estimulação ou inibição de NLRs pode acontecer de maneira dependente do modelo estudado. Diferenças entre os achados de camundongos e humanos também devem ser consideradas.

Além da inibição de células Th17 pela via de NOD2-RIP2, os dados também demonstraram que essa via induz células Th1 na LV, uma vez que animais $N o d 2^{-/-}$e Rip $^{-/-}$ apresentaram uma deficiência marcante em células $\mathrm{T} \mathrm{CD} 3^{+} \mathrm{CD} 4^{+}$produtoras de IFN- $\gamma$. O papel de NOD2 na indução da resposta Th1 em modelo de toxoplasmose já foi demonstrado (Shaw et al., 2009). Além disso, outros trabalhos mostram que na ausência de RIP2, animais infectados com L. monocytogenes possuem defeito na indução de células Th1 (Chin et al., 2002). A deficiência em proteínas componentes do inflamassoma de NLRC4 também resulta em uma atividade inadequada de células Th1 em modelo de infecção com a bactéria intracelular Anaplasma phagocytophilum (Pedra et al., 2007).

O papel de NOD2 no reconhecimento de bactérias intracelulares tem sido extensivamente investigado (Opitz et al., 2004; Shin et al., 2008; Geddes et al., 2010; Kim et al., 2011), visto que esse receptor foi classicamente descrito como receptor intracelular (citoplasmático) da imunidade inata (Meylan et al., 2006; Wilmanski et al., 2008) e cujo primeiro papel atribuído foi o reconhecimento de peptideoglicanos na parede celular de bactérias vivas. Estudos posteriores demonstraram que além de componentes bacterianos, NOD2 também poderia detectar, dentre outras coisas, produtos de protozoários e ativar a resposta do hospedeiro 
contra parasitos. (Finney et al., 2009). Nós vimos que 6 horas após a infecção in vivo, células dendríticas do baço expressando NOD2, migram para a região da polpa branca e, in vitro, $24 \mathrm{~h}$ após a infecção de BMDCs, o NOD2 é colocalizado com o parasito, sugerindo que esse receptor pode participar do reconhecimento da L. infantum. A Leishmania é um parasito intracelular cuja forma de entrada na célula origina vesículas endossomais, e, por esse motivo, essas vesículas precisam ter a vigilância reforçada. Já foi descrito que os TLRs endossomais, TLR3, TLR7, TLR 8 e TLR9 estão envolvidos na proteção contra parasitos do gênero Leishmania (Flandin et al., 2006; Zhang e Matlashewski, 2008; Paun et al., 2011; Sacramento et al., 2015). Na presença de estímulo ou agente infeccioso, as membranas endossomais em células dendríticas ou macrófagos funcionam como plataformas especializadas para o recrutamento de NOD2 e RIP2, os quais também podem ser encontrados ancorados na membrana plasmática (Barnich et al., 2005; Nakamura et al., 2014). Inclusive, existem evidências de que a formação do endolisossomo é necessária para que a sinalização via NOD2 ocorra (Herskovits et al., 2007). Esse recrutamento vem sendo descrito como dependente dos complexos formados pelas proteínas SLC15A3 e/ou SLC14A4 (Nakamura et al., 2014); Rac1, uma GTPase da família Rho envolvida com modulação da actina e organização do citoesqueleto, (Legrand-Poels et al., 2007; Eitel et al., 2008); CD147, uma glicoproteína transmembrana (Till et al., 2008); peripheral membrane protein FERM e PDZ-domain-containing 2 (FRMPD2), as quais podem servir como ancoramento para NOD2 na membrana (Lipinski et al., 2012). A diminuição da expressão de alguma dessas proteínas reduz a presença de NOD2 no compartimento de membrana e altera a sua atividade (Boyle et al., 2014). Além disso, NOD2 tem sido implicado com o recrutamento de moléculas parceiras (como RIP2) para a membrana, formando complexos de sinalização ativos (Lecine et al., 2007). Esse evento aumenta a capacidade de monitoramento e indução da resposta pelos NLRs. Outra possibilidade de ativação de NOD2 pela Leishmania é que, por vezes, os parasitos escapam dessas vesículas ácidas, caem no citosol e podem ativar receptores 
citoplasmáticos (Lima-Junior et al., 2013). O recrutamento de NOD2 para a membrana plasmática também recruta a autophagy-related protein 16-like 1 (ATG16L1), proteína relacionada com o processo de autofagia (Travassos, Carneiro, Girardin, et al., 2010; Travassos, Carneiro, Ramjeet, et al., 2010). O envolvimento de NOD2 na autofagia é uma descoberta recente e o seu papel preciso ainda é controverso. Nesse trabalho não foi investigado a relação de NOD2-RIP2 com autofagia na LV.

A importância das moléculas NOD2 e RIP2 durante a infecção in vivo por L. infantum foi demonstrada através do aumento da susceptibilidade encontrada nos animais $\mathrm{Nod}^{-/-}$e Rip2 $2^{-/-}$, os quais apresentaram maiores cargas parasitárias em relação aos animais WT, e pronunciada hepatoesplenomegalia. Animais deficientes da sinalização de IL-17RA apresentam o baço e o fígado significativamente menores do que camundongos WT durante o curso da infecção por $L$. infantum por até 8 semanas. Esse fato foi correlacionado com a menor inflamação hepática nos animais $1 l 17 \mathrm{ra}^{-/}$, sugerindo que a IL-17A, apesar de atuar na morte do parasito, possui papel indutor de inflamação e hepatoesplenomegalia (Nascimento et al., 2015). Baseando-se nesses dados, pode-se inferir que a hepatoesplenomegalia observada nos animais $N o d 2^{-/-}$e Rip $2^{-/-}$pode acontecer em decorrência dos maiores níveis de IL-17A que esses animais apresentam. Além disso, apesar da maior oferta de IL-17A, que deveria contribuir para a morte dos parasitos, a drástica redução de Th1 nos camundongos $\operatorname{Nod2}^{-/-}$e $\operatorname{Rip}^{-/-}$foi determinante para a suscetibilidade desses animais. Vale ressaltar que o papel de IFN- $\gamma$ em induzir a produção de NO em macrófagos infectados é bem mais potente do que o desempenhado pela IL-17A (Nascimento et al., 2015). Ademais, a resposta Th1 é classicamente conhecida por promover proteção contra LC e LV (Pearson e Steigbigel, 1981; Miralles et al., 1994; Alexander e Bryson, 2005). A via de NOD-RIP2 também é essencial para compor os mecanismos de defesa do hospedeiro contra a infecção por Chlamydophila pneumoniae (Shimada et al., 2009), S. aureus (Mccully et al., 2008), T. cruzi (Silva et al., 2010), L. monocytogenes (Chin et al., 2002), H. 
pilori (Fritz et al., 2007), T. gondii (Shaw et al., 2009), E. coli (Kim et al., 2004) e Pseudomonas aeruginosa (Travassos et al., 2005). Em modelo de infecção por L. infantum, camundongos $\mathrm{Nodl}^{-/-}$não apresentaram nenhum fenótipo alterado, comparado com camundongos WT (dados não mostrados).

Este trabalho apresenta evidências experimentais que mostram que a modulação da resposta imune adaptativa pela via de NOD2-RIP2 ocorre de maneira extrínseca ao linfócito,

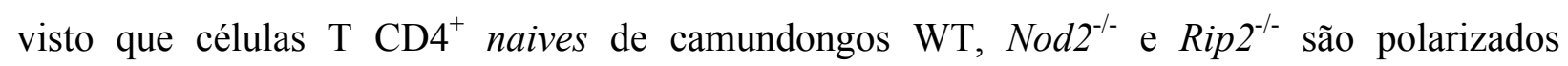
igualmente na presença de fatores indutores de Th1 ou Th17. Entretanto, quando linfócitos WT naives foram cocultivados com células dendríticas oriundas de animais $\operatorname{Nod2}^{-/-}$ou Rip2 $2^{-/-}$, nós pudemos observar que sua diferenciação em Th1 foi prejudicada, ao passo que tiveram expressão de IL-17A aumentada, comparado com os linfócitos em cocultivo com células dendríticas WT. Esses dados demonstram que a capacidade da via de NOD2-RIP2 em modular a diferenciação dos linfócitos é dependente de fatores intrínsecos da célula dendrítica, evento que ocorre devido à alteração do padrão de citocinas produzidas por essas células na ausência de NOD2 e RIP2. De maneira interessante, mesmo com aumento na expressão de transcritos para Il12/23p40, a produção de IL-12p70 foi prejudicada, visto que a expressão de mRNA para Il12p35 foi regulada negativamente. Esse fenômeno já foi observado em outros modelos de infecção, como L. monocytogenes (Chin et al., 2002) e Mycobacterium avium (Carvalho et al., 2015); ou ainda em células dendríticas humanas estimuladas com MDP e agonistas de TLRs (Tada et al., 2005) . Outros trabalhos possuem dados contrários e mostram que a deficiência de

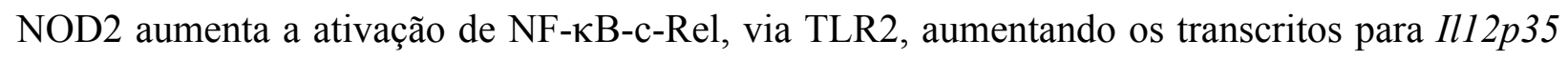
e, consequentemente, a reposta Th1. Esse fenótipo de aumento de linfócitos Th1 foi relacionado com a susceptibilidade na doença de Crohn, porém, na época desse estudo as células Th17 ainda não haviam sido descritas (Watanabe et al., 2004). Dois anos depois, esse mesmo grupo mostrou que a sinalização via NOD2 inibe a ativação de NF-אB por TLR2. Esses dados controversos 
podem ser justificados pelo fato de que a sinalização de NOD2 pode ocorrer em sinergismo ou antagonismo com outros receptores da imunidade inata, principalmente TLRs, o que irá modular significativamente os produtos finais da resposta, dependendo do modelo (patógeno/dano) e oferta de antígeno. Kim e colaboradores demonstraram de maneira muito elegante que NOD2 é capaz de sentir a intensidade da sinalização mediada por TLR4, resultando em uma estimulação sinérgica na produção de IL-12 quando a sinalização via TLR4 possui baixa intensidade, ou inibição da síntese de IL-12 quando a sinalização de TLR4 é intensificada, contribuindo tanto para manutenção da homeostase quanto para indução da resposta, dependendo do sinal ativador da via (Kim et al., 2015).

A modulação da expressão de IL-12 e IL-23 constitui eventos complexos e extensivamente estudados devido à importância dessas duas citocinas na polarização de linfócitos Th1 e Th17, respectivamente, tendo, portanto, implicância em doenças autoimunes e infecciosas, por exemplo. O único evento que encontramos estar relacionado com aumento de Th17 em animais Nod2 $^{-/}$e Rip $2^{-/-}$foi a maior quantidade de IL-12/23p40 e IL-23 produzidas por células dendríticas após a infecção. Os altos níveis de IL-12/23p40 na ausência de NOD2 e RIP2 não acarretou o aumento de IL-12, pois a sua outra subunidade, Il12p35, foi inibida, ao passo que os níveis de RNAm para Il23p19 foram mantidos. De fato, já foi demonstrado que a ativação de NOD2 induz a expressão da família do microRNA (miR)-29 em células dendríticas humanas, o que limita a produção de IL-23. Isso acontece pois o miR29 tem como alvo pós transcricional direto a Il12/23p40. Portanto, na ausência de NOD2 há maior quantidade de IL12/23p40, com aumento de IL-23 e Th17, evento relacionado à susceptibilidade na doença de Crohn (Brain et al., 2013).

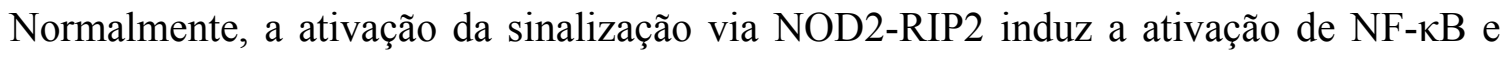
MAPKs de maneira independente ou em sinergismo com os TLRs, promovendo a produção de citocinas e quimiocinas e induzindo inflamação (Kobayashi et al., 2005; Kufer et al., 2006; 
Hasegawa et al., 2008). Nós observamos que, na ausência de NOD2 e RIP2, a fosforilação das quinases p38 e JNK foi diminuída em células dendríticas infectadas com L. infantum e, certamente, foi o evento responsável pela diminuição da oferta de IL-12. A Leishmania induz a fosforilação de ERK1/ERK2, porém, nenhuma alteração foi vista na fosforilação dessa MAPK na ausência de NOD2 e RIP2, possivelmente porque a sinalização via outros receptores (e.g. TLRs) compensou a falta de NOD2 e RIP2. Caruso e colaboradores também demostram que a sinalização via NOD2-RIP2 medeia o recrutamento e ativação da serina/treonina quinase TAK1, que, após uma cascata de eventos subsequentes, culmina com a ativação do complexo IKK e da via das MAPKs (Caruso et al., 2014). De fato, já foi demonstrado que a ativação simultânea de TLR4, com LPS, e de NOD2, com MDP, leva a produção de citocinas pró-inflamatórias via fosforilação de p38 e JNK (Windheim et al., 2007). Além disso, bactérias como S. pneumoniae (Opitz et al., 2004) e E. coli também ativam componentes das MAPKs via NOD2.

Sendo o baço o órgão alvo da infecção por L. infantum e o maior órgão linfóide secundário, o presente estudo também analisou as diferentes populações de células dendríticas esplênicas e seu papel na indução da resposta imune adaptativa protetora contra esse parasito. O baço é dividido estruturalmente e funcionalmente em polpas vermelha e branca, e, entre essas duas regiões, está a zona marginal (ZM, em camundongos) ou a zona perifolicular (em humanos) (Mebius e Kraal, 2005). O sangue é liberado por arteríolas terminais na polpa vermelha, que o filtra abertamente, sem vasos sanguíneos (Nolte et al., 2003). Caso presente, componentes de uma infecção são detectados por células (fagócitos) da polpa vermelha e ZM (Bronte e Pittet, 2013). Uma vez ativadas, essas células migram para o interior da polpa branca através de um canal de ligação existente na ZM, chamado bridging channel. A maioria dos linfócitos estão localizados na polpa branca e, de maneira similar aos linfonodos, lá é iniciada a resposta imunológica adaptativa. No baço dos camundongos, as populações de células dendríticas foram divididas em pDCs, moDCs e cDCs. As cDCs são as principais APCs para 
induzir resposta em células $\mathrm{T}$ naives (Meredith et al., 2012), e são subdivididas em $\mathrm{CD} 8 \alpha \alpha^{+} \mathrm{XCR}^{+}$, dependentes do fator de transcrição Batf3 e distribuídas por todas as regiões do baço, e $\mathrm{CD}^{+} 33 \mathrm{D} 1^{+}$, dependentes de IRF4 e localizadas nas regiões de bridging channel.. Essas duas populações são descritas por expressarem tanto Nod2 quanto Rip2 (http://www.immgen.org), mas as células dendríticas $\mathrm{CD} 8 \alpha \alpha^{+} \mathrm{XCR} 1^{+}$constituem uma fonte muito mais importante de IL-12, atuando ativamente na indução de células Th1 (Rissoan et al., 1999; Maldonado-Lopez et al., 2001). Por outro lado, as células $\mathrm{CD}^{+} 33 \mathrm{D} 1^{+}$são descritas por atuarem na polarização por perfil Th17 (Persson et al., 2013; Schlitzer et al., 2013; Wenzel et al., 2015). Nós vimos que camundongos $\mathrm{Nod}^{-/-}$e $\operatorname{Rip}^{2 /-}$ possuem alterações nas quantidades de células Th1 e Th17, sendo Th1 diminuído devido à baixa oferta de IL-12, e Th17 aumentado. Entretanto, esse fato não foi relacionado com alterações nas populações de células dendríticas $\mathrm{CD} 8 \alpha \alpha^{+} \mathrm{XCR}^{+}$ou $\mathrm{CD}^{+} 33 \mathrm{D} 1^{+}$, as quais se mantiveram semelhantes às quantidades dos animais WT antes ou após a infecção. Além disso, esses dois grupos de células dendríticas, e também a população duplo negativa, foram suscetíveis à infecção por L. infantum.

Animais $B a t f 3^{-/-}$não possuem células dendríticas $\mathrm{CD} 8 \alpha \alpha^{+} \mathrm{XCR} 1^{+}$e, conforme esperado, tiveram redução de células Th1. Curiosamente esses animais apresentaram fenótipo semelhante àquele encontrado nos camundongos $\operatorname{Nod}^{-/-}$e Rip2 $2^{-/-}$, com maior quantidade de células Th17. Em conjunto esses dados sugerem que a expressão de NOD2 e RIP2 contribui para a produção de IL-12 por células dendríticas $\mathrm{CD} 8 \alpha \alpha^{+} \mathrm{XCR}^{+}$, colaborando significantemente para o balanço da imunidade adaptativa ser direcionado para o perfil Th1. De fato, na ausência de Batf3 os camundongos são mais susceptíveis à infecção, como observado nos animais $N o d 2^{-/-}$e Rip2 $2^{-/-}$. Dados bastante semelhantes foram encontrados em modelo de LC por L. major, em experimentos feitos principalmente em linfonodos. Camundongos Batf $^{-/-}$foram mais susceptíveis à infecção, apresentaram maiores lesões na orelha e maiores cargas parasitárias, devido à redução da oferta de IL-12 e, consequentemente, de linfócitos Th1. Esses animais 
também apresentaram aumento de células Th17, Th2 e células T reguladoras (Ashok et al., 2014; Martinez-Lopez et al., 2015). Ainda, no modelo de infecção por T. gondii, as células dendríticas $\mathrm{CD} \alpha \alpha \alpha^{+}$são críticas para indução da resposta Th1 via produção de IL-12 (Mashayekhi et al., 2011).

Conjuntamente, os dados apresentados no presente trabalho fornecem detalhes sobre as bases moleculares da interação entre a $L$. infantum $x$ célula hospedeira. Nossos resultados demonstram o papel crítico de NOD2 e RIP2 em um modelo que conecta os mecanismos de reconhecimento do parasito pela imunidade inata com a indução da resposta imunológica adaptativa protetora na LV. A identificação desses eventos possui extrema relevância pois contribuem para a construção do entendimento dos mecanismos complexos que envolvem a imunopatogênese das leishmanioses, bem como oferece suporte para novas perspectivas de intervenções imunes, desenvolvimento de estratégias racionais de tratamento e profilaxia dessa doença negligenciada tão difundida no território nacional. 
VI. Sumárío 
Os dados gerados no presente trabalho demonstram que:

- A LV humana e experimental inibem a diferenciação de células Th17;

- Células B são fonte celular importante de IL-17A durante a infecção por L. infantum;

- A infecção por L. infantum induz a expressão de RNAm para Nod2 e Rip2 em células dendríticas;

- NOD2 é colocalizado com o parasito na célula dendrítica infectada;

- A via de sinalização de NOD2-RIP2 induz linfócitos Th1 mas inibe as células Th17;

- NOD2 e RIP2 contribuem para a resistência do hospedeiro contra a infecção;

- A via de sinalização de NOD2-RIP2 exerce papel extrínseco na modulação de linfócitos Th1 e Th17, via células dendríticas;

- NOD2 e RIP2 sinalizam via p38 e JNK para induzir a produção de IL-12 em células dendríticas infectadas;

- A via de NOD2-RIP2 inibe a produção de IL-12/23p40 e IL-23 por células dendríticas infectadas;

- Células dendríticas $\mathrm{CD} 8 \alpha \alpha^{+} \mathrm{XCR}^{+}$são críticas para indução da resposta Th1, mas não para Th17 durante infecção por L. infantum. 
VII. Conclusão 
A via de sinalização de NOD2-RIP2 é crítica para a resistência do hospedeiro à infecção por L. infantum. Esse controle é realizado através da modulação da produção de citocinas pela célula dendrítica, a qual possui efeito indutor do padrão Th1, porém inibe a diferenciação de linfócitos Th17. Nesse contexto, células B compõem uma fonte importante de IL-17A na LV causada por L. infantum. 
VIII. Modelo Proposto 


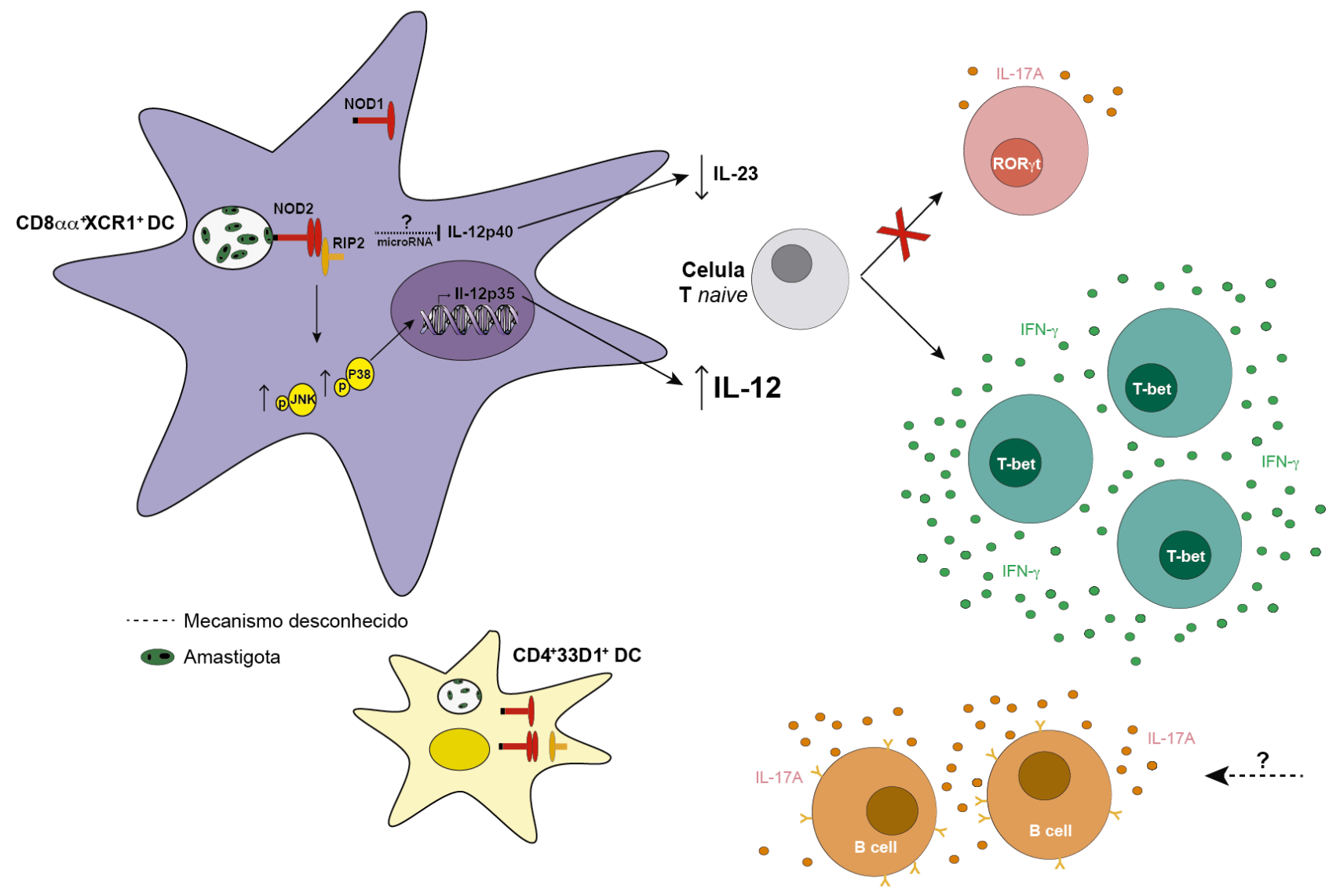

Figura 23: Modelo proposto - A sinalização via NOD2-RIP2 contribui para a modulação da imunidade adaptativa celular durante a infecção por Leishmania infantum. Células dendríticas $\operatorname{CD} 8 \alpha \alpha^{+} \mathrm{XCR} 1^{+} \mathrm{e}$ $33 \mathrm{D} 1^{+} \mathrm{CD} 4^{+}$expressam NOD2 e RIP2 e são suscetíveis à infecção por L. infantum. Após a infecção, o NOD2 é recrutado e sinaliza via RIP2, induzindo altas quantidades de IL-12 via fosforilação de p38 e JNK. Células dendríticas $\mathrm{CD} 8 \alpha \alpha^{+} \mathrm{XCR}^{+}$são a principal fonte de IL-12. Essa mesma via inibe IL-12/23p40, limitando a oferta de IL-23 e inibindo a diferenciação de células Th17. Nesse microambiente, a imunidade adaptativa celular é direcionada principalmente para a diferenciação de linfócitos Th1. Nesse contexto, células B garantem a produção de IL-17A durante a LV por L. infantum. Os mecanismos pelos quais as células B produtoras de IL-17A são induzidas permanecem desconhecidos. 


\section{Referências Bibliográficas}


ALEXANDER, J.; BRYSON, K. T helper (h)1/Th2 and Leishmania: paradox rather than paradigm. Immunol Lett, v. 99, n. 1, p. 17-23, Jun 15 2005. ISSN 0165-2478 (Print)

0165-2478 (Linking). Disponível em: < http://www.ncbi.nlm.nih.gov/pubmed/15894106 >.

ALIBERTI, J. et al. Essential role for ICSBP in the in vivo development of murine CD8alpha + dendritic cells. Blood, v. 101, n. 1, p. 305-10, Jan 1 2003. ISSN 0006-4971 (Print)

0006-4971 (Linking). Disponível em: < http://www.ncbi.nlm.nih.gov/pubmed/12393690 >.

ALVAR, J. et al. Canine leishmaniasis. Adv Parasitol, v. 57, p. 1-88, 2004. ISSN 0065-308X (Print)

0065-308X (Linking). Disponível em: < http://www.ncbi.nlm.nih.gov/pubmed/15504537 >.

ASHOK, D. et al. Cross-presenting dendritic cells are required for control of Leishmania major infection. Eur J Immunol, v. 44, n. 5, p. 1422-32, May 2014. ISSN 1521-4141 (Electronic)

0014-2980 (Linking). Disponível em: < http://www.ncbi.nlm.nih.gov/pubmed/24643576 >.

ATHMAN, R.; PHILPOTT, D. Innate immunity via Toll-like receptors and Nod proteins. Curr Opin Microbiol, v. 7, n. 1, p. 25-32, Feb 2004. ISSN 1369-5274 (Print)

1369-5274 (Linking). Disponível em: < http://www.ncbi.nlm.nih.gov/pubmed/15036136 >.

AWASTHI, A.; MATHUR, R. K.; SAHA, B. Immune response to Leishmania infection. Indian J Med Res, v. 119, n. 6, p. 238-58, Jun 2004. ISSN 0971-5916 (Print)

0971-5916 (Linking). Disponível em: < http://www.ncbi.nlm.nih.gov/pubmed/15243162 >.

BABALOO, Z.; KAYE, P. M.; ESLAMI, M. B. Interleukin-13 in Iranian patients with visceral leishmaniasis: relationship to other Th2 and Th1 cytokines. Trans R Soc Trop Med Hyg, v. 95, n. 1, p. 85-8, Jan-Feb 2001. ISSN 0035-9203 (Print)

0035-9203 (Linking). Disponível em: < http://www.ncbi.nlm.nih.gov/pubmed/11280075 >.

BADARO, R. et al. rK39: a cloned antigen of Leishmania chagasi that predicts active visceral leishmaniasis. J Infect Dis, v. 173, n. 3, p. 758-61, Mar 1996. ISSN 0022-1899 (Print)

0022-1899 (Linking). Disponível em: < http://www.ncbi.nlm.nih.gov/pubmed/8627048>.

BADARO, R. et al. New perspectives on a subclinical form of visceral leishmaniasis. J Infect Dis, v. 154, n. 6, p. 1003-11, Dec 1986. ISSN 0022-1899 (Print)

0022-1899 (Linking). Disponível em: < http://www.ncbi.nlm.nih.gov/pubmed/3782864 >

BARNICH, N. et al. Membrane recruitment of NOD2 in intestinal epithelial cells is essential for nuclear factor- $\{$ kappa $\}$ B activation in muramyl dipeptide recognition. J Cell Biol, v. 170, n. 1, p. 21-6, Jul 4 2005. ISSN 0021-9525 (Print)

0021-9525 (Linking). Disponível em: < http://www.ncbi.nlm.nih.gov/pubmed/15998797 >. 
BAUQUET, A. T. et al. The costimulatory molecule ICOS regulates the expression of c-Maf and IL-21 in the development of follicular T helper cells and TH-17 cells. Nat Immunol, v. 10, n. 2, p. 167-75, Feb 2009. ISSN 1529-2916 (Electronic)

1529-2908 (Linking). Disponível em: < http://www.ncbi.nlm.nih.gov/pubmed/19098919 >.

BELKAID, Y. et al. The role of interleukin (IL)-10 in the persistence of Leishmania major in the skin after healing and the therapeutic potential of anti-IL-10 receptor antibody for sterile cure. J Exp Med, v. 194, n. 10, p. 1497-506, Nov 19 2001. ISSN 0022-1007 (Print)

0022-1007 (Linking). Disponível em: < http://www.ncbi.nlm.nih.gov/pubmed/11714756 >.

BELKAID, Y. et al. CD8+ T cells are required for primary immunity in C57BL/6 mice following low-dose, intradermal challenge with Leishmania major. J Immunol, v. 168, n. 8, p. 3992-4000, Apr 15 2002. ISSN 0022-1767 (Print)

0022-1767 (Linking). Disponível em: < http://www.ncbi.nlm.nih.gov/pubmed/11937556 >.

BERIOU, G. et al. TGF-beta induces IL-9 production from human Th17 cells. J Immunol, v. 185, n. 1, p. 46-54, Jul 1 2010. ISSN 1550-6606 (Electronic)

0022-1767 (Linking). Disponível em: < http://www.ncbi.nlm.nih.gov/pubmed/20498357>.

BERMEJO, D. A. et al. Trypanosoma cruzi trans-sialidase initiates a program independent of the transcription factors RORgammat and Ahr that leads to IL-17 production by activated B cells. Nat Immunol, v. 14, n. 5, p. 514-22, May 2013. ISSN 1529-2916 (Electronic)

1529-2908 (Linking). Disponível em: < http://www.ncbi.nlm.nih.gov/pubmed/23563688>.

BERN, C. et al. The epidemiology of visceral leishmaniasis and asymptomatic leishmanial infection in a highly endemic Bangladeshi village. Am J Trop Med Hyg, v. 76, n. 5, p. 909-14, May 2007. ISSN 0002-9637 (Print)

0002-9637 (Linking). Disponível em: < http://www.ncbi.nlm.nih.gov/pubmed/17488915 >.

BERTIN, J. et al. Human CARD4 protein is a novel CED-4/Apaf-1 cell death family member that activates NF-kappaB. J Biol Chem, v. 274, n. 19, p. 12955-8, May 7 1999. ISSN 0021 9258 (Print)

0021-9258 (Linking). Disponível em: < http://www.ncbi.nlm.nih.gov/pubmed/10224040 >.

BERUBE, J. et al. Distinct intracellular signaling pathways control the synthesis of IL-8 and RANTES in TLR1/TLR2, TLR3 or NOD1 activated human airway epithelial cells. Cell Signal, v. 21, n. 3, p. 448-56, Mar 2009. ISSN 1873-3913 (Electronic)

0898-6568 (Linking). Disponível em: < http://www.ncbi.nlm.nih.gov/pubmed/19121387 >.

BIRON, C. A.; GAZZINELLI, R. T. Effects of IL-12 on immune responses to microbial infections: a key mediator in regulating disease outcome. Curr Opin Immunol, v. 7, n. 4, p. 485-96, Aug 1995. ISSN 0952-7915 (Print)

0952-7915 (Linking). Disponível em: < http://www.ncbi.nlm.nih.gov/pubmed/7495512>. 
BOGDAN, C.; ROLLINGHOFF, M.; DIEFENBACH, A. The role of nitric oxide in innate immunity. Immunol Rev, v. 173, p. 17-26, Feb 2000. ISSN 0105-2896 (Print)

0105-2896 (Linking). Disponível em: < http://www.ncbi.nlm.nih.gov/pubmed/10719664 >.

BOLGER, A. M.; LOHSE, M.; USADEL, B. Trimmomatic: a flexible trimmer for Illumina sequence data. Bioinformatics, v. 30, n. 15, p. 2114-20, Aug 1 2014. ISSN 1367-4811 (Electronic)

1367-4803 (Linking). Disponível em: < http://www.ncbi.nlm.nih.gov/pubmed/24695404 >.

BONECA, I. G. et al. A critical role for peptidoglycan N-deacetylation in Listeria evasion from the host innate immune system. Proc Natl Acad Sci U S A, v. 104, n. 3, p. 997-1002, Jan 16 2007. ISSN 0027-8424 (Print)

0027-8424 (Linking). Disponível em: < http://www.ncbi.nlm.nih.gov/pubmed/17215377>.

BONEN, D. K. et al. Crohn's disease-associated NOD2 variants share a signaling defect in response to lipopolysaccharide and peptidoglycan. Gastroenterology, v. 124, n. 1, p. 140-6, Jan 2003. ISSN 0016-5085 (Print)

0016-5085 (Linking). Disponível em: < http://www.ncbi.nlm.nih.gov/pubmed/12512038>.

BOYLE, J. P.; PARKHOUSE, R.; MONIE, T. P. Insights into the molecular basis of the NOD2 signalling pathway. Open Biol, v. 4, n. 12, Dec 2014. ISSN 2046-2441 (Electronic)

2046-2441 (Linking). Disponível em: < http://www.ncbi.nlm.nih.gov/pubmed/25520185 >.

BRAIN, O. et al. The intracellular sensor NOD2 induces microRNA-29 expression in human dendritic cells to limit IL-23 release. Immunity, v. 39, n. 3, p. 521-36, Sep 19 2013. ISSN 10974180 (Electronic)

1074-7613 (Linking). Disponível em: < http://www.ncbi.nlm.nih.gov/pubmed/24054330>.

BRONTE, V.; PITTET, M. J. The spleen in local and systemic regulation of immunity.

Immunity, v. 39, n. 5, p. 806-18, Nov 14 2013. ISSN 1097-4180 (Electronic)

1074-7613 (Linking). Disponível em: < http://www.ncbi.nlm.nih.gov/pubmed/24238338>.

BRUSTLE, A. et al. The development of inflammatory T(H)-17 cells requires interferonregulatory factor 4. Nat Immunol, v. 8, n. 9, p. 958-66, Sep 2007. ISSN 1529-2908 (Print)

1529-2908 (Linking). Disponível em: < http://www.ncbi.nlm.nih.gov/pubmed/17676043 > .

BUFFET, P. A. et al. Culture microtitration: a sensitive method for quantifying Leishmania infantum in tissues of infected mice. Antimicrob Agents Chemother, v. 39, n. 9, p. 2167-8, Sep 1995. ISSN 0066-4804 (Print)

0066-4804 (Linking). Disponível em: < http://www.ncbi.nlm.nih.gov/pubmed/8540741 >.

CAETANO, B. C. et al. Intrinsic expression of Nod2 in CD4+ T lymphocytes is not necessary for the development of cell-mediated immunity and host resistance to Toxoplasma gondii. Eur $\mathbf{J}$ Immunol, v. 41, n. 12, p. 3627-31, Dec 2011. ISSN 1521-4141 (Electronic) 
0014-2980 (Linking). Disponível em: < http://www.ncbi.nlm.nih.gov/pubmed/22002196 >.

CALDAS, A. J. et al. Risk factors associated with asymptomatic infection by Leishmania chagasi in north-east Brazil. Trans R Soc Trop Med Hyg, v. 96, n. 1, p. 21-8, Jan-Feb 2002. ISSN 0035-9203 (Print)

0035-9203 (Linking). Disponível em: < http://www.ncbi.nlm.nih.gov/pubmed/11925984 >.

CARUSO, R. et al. NOD1 and NOD2: signaling, host defense, and inflammatory disease. Immunity, v. 41, n. 6, p. 898-908, Dec 18 2014. ISSN 1097-4180 (Electronic)

1074-7613 (Linking). Disponível em: < http://www.ncbi.nIm.nih.gov/pubmed/25526305 >.

CARVALHO, E. M. et al. Antigen-specific immunosuppression in visceral leishmaniasis is cell mediated. J Clin Invest, v. 83, n. 3, p. 860-4, Mar 1989. ISSN 0021-9738 (Print)

0021-9738 (Linking). Disponível em: < http://www.ncbi.nlm.nih.gov/pubmed/2522103 >.

CARVALHO, E. M. et al. Absence of gamma interferon and interleukin 2 production during active visceral leishmaniasis. J Clin Invest, v. 76, n. 6, p. 2066-9, Dec 1985. ISSN 0021-9738 (Print)

0021-9738 (Linking). Disponível em: < http://www.ncbi.nlm.nih.gov/pubmed/3935667 >.

CARVALHO, N. B. et al. Nucleotide-binding oligomerization domain-2 (NOD2) regulates type-1 cytokine responses to Mycobacterium avium but is not required for host control of infection. Microbes Infect, v. 17, n. 5, p. 337-44, May 2015. ISSN 1769-714X (Electronic) 1286-4579 (Linking). Disponível em: < http://www.ncbi.nlm.nih.gov/pubmed/25817335 >.

CHANG, H. C. et al. The transcription factor PU.1 is required for the development of IL-9producing T cells and allergic inflammation. Nat Immunol, v. 11, n. 6, p. 527-34, Jun 2010. ISSN 1529-2916 (Electronic)

1529-2908 (Linking). Disponível em: < http://www.ncbi.nlm.nih.gov/pubmed/20431622 >.

CHEN, G. et al. NOD-like receptors: role in innate immunity and inflammatory disease. Annu Rev Pathol, v. 4, p. 365-98, 2009. ISSN 1553-4014 (Electronic)

1553-4006 (Linking). Disponível em: < http://www.ncbi.nlm.nih.gov/pubmed/18928408 >.

CHIN, A. I. et al. Involvement of receptor-interacting protein 2 in innate and adaptive immune responses. Nature, v. 416, n. 6877, p. 190-4, Mar 14 2002. ISSN 0028-0836 (Print)

0028-0836 (Linking). Disponível em: < http://www.ncbi.nlm.nih.gov/pubmed/11894097 >.

CLAES, A. K.; ZHOU, J. Y.; PHILPOTT, D. J. NOD-Like Receptors: Guardians of Intestinal Mucosal Barriers. Physiology (Bethesda), v. 30, n. 3, p. 241-250, May 2015. ISSN 1548-9221 (Electronic)

1548-9221 (Linking). Disponível em: < http://www.ncbi.nlm.nih.gov/pubmed/25933824 >.

COULOMBE, F. et al. Increased NOD2-mediated recognition of N-glycolyl muramyl dipeptide. J Exp Med, v. 206, n. 8, p. 1709-16, Aug 3 2009. ISSN 1540-9538 (Electronic) 
0022-1007 (Linking). Disponível em: < http://www.ncbi.nlm.nih.gov/pubmed/19581406 >.

CRUZ, I. et al. Leishmania/HIV co-infections in the second decade. Indian J Med Res, v. 123, n. 3, p. 357-88, Mar 2006. ISSN 0971-5916 (Print)

0971-5916 (Linking). Disponível em: < http://www.ncbi.nlm.nih.gov/pubmed/16778317>.

DA SILVA, M. R.; STEWART, J. M.; COSTA, C. H. Sensitivity of bone marrow aspirates in the diagnosis of visceral leishmaniasis. Am J Trop Med Hyg, v. 72, n. 6, p. 811-4, Jun 2005. ISSN 0002-9637 (Print)

0002-9637 (Linking). Disponível em: < http://www.ncbi.nlm.nih.gov/pubmed/15964968>.

DESJEUX, P. Leishmaniasis: current situation and new perspectives. Comp Immunol Microbiol Infect Dis, v. 27, n. 5, p. 305-18, Sep 2004. ISSN 0147-9571 (Print)

0147-9571 (Linking). Disponível em: < http://www.ncbi.nlm.nih.gov/pubmed/15225981 >.

DOBSON, D. E. et al. Leishmania major survival in selective Phlebotomus papatasi sand fly vector requires a specific SCG-encoded lipophosphoglycan galactosylation pattern. PLoS Pathog, v. 6, n. 11, p. e1001185, 2010. ISSN 1553-7374 (Electronic)

1553-7366 (Linking). Disponível em: < http://www.ncbi.nlm.nih.gov/pubmed/21085609 >.

DUTRA, M. S. et al. Association of a NOD2 gene polymorphism and T-helper 17 cells with presumed ocular toxoplasmosis. J Infect Dis, v. 207, n. 1, p. 152-63, Jan 1 2013. ISSN $1537-$ 6613 (Electronic)

0022-1899 (Linking). Disponível em: < http://www.ncbi.nlm.nih.gov/pubmed/23100559>.

ECONOMOU, M. et al. Differential effects of NOD2 variants on Crohn's disease risk and phenotype in diverse populations: a metaanalysis. Am J Gastroenterol, v. 99, n. 12, p. 2393404, Dec 2004. ISSN 0002-9270 (Print)

0002-9270 (Linking). Disponível em: < http://www.ncbi.nlm.nih.gov/pubmed/15571588 >

EITEL, J. et al. Beta-PIX and Rac1 GTPase mediate trafficking and negative regulation of NOD2. J Immunol, v. 181, n. 4, p. 2664-71, Aug 15 2008. ISSN 1550-6606 (Electronic)

0022-1767 (Linking). Disponível em: < http://www.ncbi.nlm.nih.gov/pubmed/18684957>.

EL-HASSAN, A. M. et al. Sudanese mucosal leishmaniasis: epidemiology, clinical features, diagnosis, immune responses and treatment. Trans R Soc Trop Med Hyg, v. 89, n. 6, p. 64752, Nov-Dec 1995. ISSN 0035-9203 (Print)

0035-9203 (Linking). Disponível em: < http://www.ncbi.nlm.nih.gov/pubmed/8594683 >.

ELIAS, K. M. et al. Retinoic acid inhibits Th17 polarization and enhances FoxP3 expression through a Stat-3/Stat-5 independent signaling pathway. Blood, v. 111, n. 3, p. 1013-20, Feb 1 2008. ISSN 0006-4971 (Print)

0006-4971 (Linking). Disponível em: < http://www.ncbi.nlm.nih.gov/pubmed/17951529 >. 
EVANS, T. G. et al. Epidemiology of visceral leishmaniasis in northeast Brazil. J Infect Dis, v. 166, n. 5, p. 1124-32, Nov 1992. ISSN 0022-1899 (Print)

0022-1899 (Linking). Disponível em: < http://www.ncbi.nlm.nih.gov/pubmed/1402024 >.

EZRA, N.; OCHOA, M. T.; CRAFT, N. Human immunodeficiency virus and leishmaniasis. J

Glob Infect Dis, v. 2, n. 3, p. 248-57, Sep 2010. ISSN 0974-8245 (Electronic)

0974-777X (Linking). Disponível em: < http://www.ncbi.nlm.nih.gov/pubmed/20927287 >.

FERWERDA, G. et al. NOD2 and toll-like receptors are nonredundant recognition systems of Mycobacterium tuberculosis. PLoS Pathog, v. 1, n. 3, p. 279-85, Nov 2005. ISSN 1553-7366 (Print)

1553-7366 (Linking). Disponível em: < http://www.ncbi.nlm.nih.gov/pubmed/16322770 >.

FINNEY, C. A. et al. Disruption of Nod-like receptors alters inflammatory response to infection but does not confer protection in experimental cerebral malaria. Am J Trop Med Hyg, v. 80, n. 5, p. 718-22, May 2009. ISSN 1476-1645 (Electronic)

0002-9637 (Linking). Disponível em: < http://www.ncbi.nlm.nih.gov/pubmed/19407112>.

FLANDIN, J. F.; CHANO, F.; DESCOTEAUX, A. RNA interference reveals a role for TLR2 and TLR3 in the recognition of Leishmania donovani promastigotes by interferon-gammaprimed macrophages. Eur J Immunol, v. 36, n. 2, p. 411-20, Feb 2006. ISSN 0014-2980 (Print)

0014-2980 (Linking). Disponível em: < http://www.ncbi.nlm.nih.gov/pubmed/16369915 >.

FORSTER, R. et al. CCR7 coordinates the primary immune response by establishing functional microenvironments in secondary lymphoid organs. Cell, v. 99, n. 1, p. 23-33, Oct 1 1999. ISSN 0092-8674 (Print)

0092-8674 (Linking). Disponível em: < http://www.ncbi.nlm.nih.gov/pubmed/10520991 >.

FRANCHI, L. et al. Function of Nod-like receptors in microbial recognition and host defense. Immunol Rev, v. 227, n. 1, p. 106-28, Jan 2009. ISSN 1600-065X (Electronic)

0105-2896 (Linking). Disponível em: < http://www.ncbi.nlm.nih.gov/pubmed/19120480 >.

FRANKE, A. et al. Genome-wide meta-analysis increases to 71 the number of confirmed Crohn's disease susceptibility loci. Nat Genet, v. 42, n. 12, p. 1118-25, Dec 2010. ISSN 15461718 (Electronic)

1061-4036 (Linking). Disponível em: < http://www.ncbi.nlm.nih.gov/pubmed/21102463 >.

FRITZ, J. H. et al. Nod1-mediated innate immune recognition of peptidoglycan contributes to the onset of adaptive immunity. Immunity, v. 26, n. 4, p. 445-59, Apr 2007. ISSN 1074-7613 (Print)

1074-7613 (Linking). Disponível em: < http://www.ncbi.nlm.nih.gov/pubmed/17433730>.

GAMA, M. E. et al. Subclinical form of the American visceral leishmaniasis. Mem Inst Oswaldo Cruz, v. 99, n. 8, p. 889-93, Dec 2004. ISSN 0074-0276 (Print) 
0074-0276 (Linking). Disponível em: < http://www.ncbi.nlm.nih.gov/pubmed/15761608 >.

GARDENER, P. J. Taxonomy of the genus Leishmania: a review of nomenclature and classification. Trop Dis Bull, v. 74, n. 12, p. 1069-88, Dec 1977. ISSN 0041-3240 (Print)

0041-3240 (Linking). Disponível em: < http://www.ncbi.nlm.nih.gov/pubmed/345571 >.

GEDDES, K. et al. Nod1 and Nod2 regulation of inflammation in the Salmonella colitis model. Infect Immun, v. 78, n. 12, p. 5107-15, Dec 2010. ISSN 1098-5522 (Electronic)

0019-9567 (Linking). Disponível em: < http://www.ncbi.nlm.nih.gov/pubmed/20921147>.

GHOSH, K. et al. Successful therapy of visceral leishmaniasis with curdlan involves T-helper 17 cytokines. J Infect Dis, v. 207, n. 6, p. 1016-25, Mar 15 2013. ISSN 1537-6613 (Electronic)

0022-1899 (Linking). Disponível em: < http://www.ncbi.nlm.nih.gov/pubmed/23255562 >.

GIRARDIN, S. E. et al. Nod2 is a general sensor of peptidoglycan through muramyl dipeptide (MDP) detection. J Biol Chem, v. 278, n. 11, p. 8869-72, Mar 14 2003. ISSN 0021-9258 (Print)

0021-9258 (Linking). Disponível em: < http://www.ncbi.nIm.nih.gov/pubmed/12527755 >.

GUILLIAMS, M. et al. Dendritic cells, monocytes and macrophages: a unified nomenclature based on ontogeny. Nat Rev Immunol, v. 14, n. 8, p. 571-8, Aug 2014. ISSN 1474-1741 (Electronic)

1474-1733 (Linking). Disponível em: < http://www.ncbi.nlm.nih.gov/pubmed/25033907 >.

HARALDSEN, G. et al. Interleukin-33 - cytokine of dual function or novel alarmin? Trends Immunol, v. 30, n. 5, p. 227-33, May 2009. ISSN 1471-4906 (Print)

1471-4906 (Linking). Disponível em: < http://www.ncbi.nlm.nih.gov/pubmed/19359217 >.

HASEGAWA, M. et al. A critical role of RICK/RIP2 polyubiquitination in Nod-induced NFkappaB activation. EMBO J, v. 27, n. 2, p. 373-83, Jan 23 2008. ISSN 1460-2075 (Electronic)

0261-4189 (Linking). Disponível em: < http://www.ncbi.nlm.nih.gov/pubmed/18079694 >.

HEGAZY, A. N. et al. Interferons direct Th2 cell reprogramming to generate a stable GATA$3(+)$ T-bet $(+)$ cell subset with combined Th2 and Th1 cell functions. Immunity, v. 32, n. 1, p. 116-28, Jan 29 2010. ISSN 1097-4180 (Electronic)

1074-7613 (Linking). Disponível em: < http://www.ncbi.nlm.nih.gov/pubmed/20079668>.

HERSKOVITS, A. A.; AUERBUCH, V.; PORTNOY, D. A. Bacterial ligands generated in a phagosome are targets of the cytosolic innate immune system. PLoS Pathog, v. 3, n. 3, p. e51, Mar 2007. ISSN 1553-7374 (Electronic)

1553-7366 (Linking). Disponível em: < http://www.ncbi.nlm.nih.gov/pubmed/17397264 >.

HILDNER, K. et al. Batf3 deficiency reveals a critical role for CD8alpha+ dendritic cells in cytotoxic T cell immunity. Science, v. 322, n. 5904, p. 1097-100, Nov 14 2008. ISSN 10959203 (Electronic) 
0036-8075 (Linking). Disponível em: < http://www.ncbi.nlm.nih.gov/pubmed/19008445 >.

HISAMATSU, T. et al. CARD15/NOD2 functions as an antibacterial factor in human intestinal epithelial cells. Gastroenterology, v. 124, n. 4, p. 993-1000, Apr 2003. ISSN 0016-5085 (Print)

0016-5085 (Linking). Disponível em: < http://www.ncbi.nlm.nih.gov/pubmed/12671896 >.

HITZLER, I. et al. Caspase-1 has both proinflammatory and regulatory properties in Helicobacter infections, which are differentially mediated by its substrates IL-1beta and IL-18. J Immunol, v. 188, n. 8, p. 3594-602, Apr 15 2012. ISSN 1550-6606 (Electronic)

0022-1767 (Linking). Disponível em: < http://www.ncbi.nlm.nih.gov/pubmed/22403439>.

INOHARA et al. NOD-LRR proteins: role in host-microbial interactions and inflammatory disease. Annu Rev Biochem, v. 74, p. 355-83, 2005. ISSN 0066-4154 (Print)

0066-4154 (Linking). Disponível em: < http://www.ncbi.nlm.nih.gov/pubmed/15952891 >.

IVANOV, II et al. The orphan nuclear receptor RORgammat directs the differentiation program of proinflammatory IL-17+ T helper cells. Cell, v. 126, n. 6, p. 1121-33, Sep 22 2006. ISSN 0092-8674 (Print)

0092-8674 (Linking). Disponível em: < http://www.ncbi.nlm.nih.gov/pubmed/16990136 >.

IWASAKI, A.; PILLAI, P. S. Innate immunity to influenza virus infection. Nat Rev Immunol, v. 14, n. 5, p. 315-28, May 2014. ISSN 1474-1741 (Electronic)

1474-1733 (Linking). Disponível em: < http://www.ncbi.nlm.nih.gov/pubmed/24762827 >.

JANEWAY, C. A., JR.; MEDZHITOV, R. Innate immune recognition. Annu Rev Immunol, v. 20, p. 197-216, 2002. ISSN 0732-0582 (Print)

0732-0582 (Linking). Disponível em: < http://www.ncbi.nlm.nih.gov/pubmed/11861602 >.

JERONIMO, S. M. et al. Natural history of Leishmania (Leishmania) chagasi infection in Northeastern Brazil: long-term follow-up. Clin Infect Dis, v. 30, n. 3, p. 608-9, Mar 2000. ISSN 1058-4838 (Print)

1058-4838 (Linking). Disponível em: < http://www.ncbi.nlm.nih.gov/pubmed/10722458>.

KANE, M. M.; MOSSER, D. M. The role of IL-10 in promoting disease progression in leishmaniasis. J Immunol, v. 166, n. 2, p. 1141-7, Jan 15 2001. ISSN 0022-1767 (Print)

0022-1767 (Linking). Disponível em: < http://www.ncbi.nlm.nih.gov/pubmed/11145695 >.

KAPSENBERG, M. L. Dendritic-cell control of pathogen-driven T-cell polarization. Nat Rev Immunol, v. 3, n. 12, p. 984-93, Dec 2003. ISSN 1474-1733 (Print)

1474-1733 (Linking). Disponível em: < http://www.ncbi.nlm.nih.gov/pubmed/14647480 >

KAYE, P.; SCOTT, P. Leishmaniasis: complexity at the host-pathogen interface. Nat Rev Microbiol, v. 9, n. 8, p. 604-15, Aug 2011. ISSN 1740-1534 (Electronic)

1740-1526 (Linking). Disponível em: < http://www.ncbi.nlm.nih.gov/pubmed/21747391 >. 
KAYE, P. M.; BLACKWELL, J. M. Postgenomic research on leishmaniasis: a critical selfappraisal. Trends Parasitol, v. 24, n. 9, p. 401-5, Sep 2008. ISSN 1471-4922 (Print)

1471-4922 (Linking). Disponível em: < http://www.ncbi.nlm.nih.gov/pubmed/18684668>.

KEESTRA, A. M. et al. A Salmonella virulence factor activates the NOD1/NOD2 signaling pathway. MBio, v. 2, n. 6, 2011. ISSN 2150-7511 (Electronic). Disponível em: < http://www.ncbi.nlm.nih.gov/pubmed/22186610 >.

KIM, D. et al. TopHat2: accurate alignment of transcriptomes in the presence of insertions, deletions and gene fusions. Genome Biol, v. 14, n. 4, p. R36, 2013. ISSN 1474-760X (Electronic)

1474-7596 (Linking). Disponível em: < http://www.ncbi.nlm.nih.gov/pubmed/23618408 >.

KIM, H. et al. A novel crosstalk between TLR4- and NOD2-mediated signaling in the regulation of intestinal inflammation. Sci Rep, v. 5, p. 12018, 2015. ISSN 2045-2322 (Electronic)

2045-2322 (Linking). Disponível em: < http://www.ncbi.nlm.nih.gov/pubmed/26153766 >.

KIM, J. G.; LEE, S. J.; KAGNOFF, M. F. Nod1 is an essential signal transducer in intestinal epithelial cells infected with bacteria that avoid recognition by toll-like receptors. Infect

Immun, v. 72, n. 3, p. 1487-95, Mar 2004. ISSN 0019-9567 (Print)

0019-9567 (Linking). Disponível em: < http://www.ncbi.nlm.nih.gov/pubmed/14977954 >.

KIM, Y. G. et al. The Nod2 sensor promotes intestinal pathogen eradication via the chemokine CCL2-dependent recruitment of inflammatory monocytes. Immunity, v. 34, n. 5, p. 769-80, May 27 2011. ISSN 1097-4180 (Electronic)

1074-7613 (Linking). Disponível em: < http://www.ncbi.nlm.nih.gov/pubmed/21565531 >.

KOBAYASHI, K. S. et al. Nod2-dependent regulation of innate and adaptive immunity in the intestinal tract. Science, v. 307, n. 5710, p. 731-4, Feb 4 2005. ISSN 1095-9203 (Electronic)

0036-8075 (Linking). Disponível em: < http://www.ncbi.nlm.nih.gov/pubmed/15692051 >.

KONECNY, P. et al. Murine dendritic cells internalize Leishmania major promastigotes, produce IL-12 p40 and stimulate primary T cell proliferation in vitro. Eur J Immunol, v. 29, n. 6, p. 1803-11, Jun 1999. ISSN 0014-2980 (Print)

0014-2980 (Linking). Disponível em: < http://www.ncbi.nlm.nih.gov/pubmed/10382742 >.

KRISHNASWAMY, J. K.; CHU, T.; EISENBARTH, S. C. Beyond pattern recognition: NODlike receptors in dendritic cells. Trends Immunol, v. 34, n. 5, p. 224-33, May 2013. ISSN 14714981 (Electronic)

1471-4906 (Linking). Disponível em: < http://www.ncbi.nlm.nih.gov/pubmed/23352728 >.

KUFER, T. A.; BANKS, D. J.; PHILPOTT, D. J. Innate immune sensing of microbes by Nod proteins. Ann N Y Acad Sci, v. 1072, p. 19-27, Aug 2006. ISSN 0077-8923 (Print)

0077-8923 (Linking). Disponível em: < http://www.ncbi.nlm.nih.gov/pubmed/17057187>. 
KUFER, T. A.; FRITZ, J. H.; PHILPOTT, D. J. NACHT-LRR proteins (NLRs) in bacterial infection and immunity. Trends Microbiol, v. 13, n. 8, p. 381-8, Aug 2005. ISSN 0966-842X (Print)

0966-842X (Linking). Disponível em: < http://www.ncbi.nlm.nih.gov/pubmed/15994078>.

KUFER, T. A. et al. The pattern-recognition molecule Nod1 is localized at the plasma membrane at sites of bacterial interaction. Cell Microbiol, v. 10, n. 2, p. 477-86, Feb 2008. ISSN 1462-5822 (Electronic)

1462-5814 (Linking). Disponível em: < http://www.ncbi.nlm.nih.gov/pubmed/17970764 >.

LASKAY, T.; VAN ZANDBERGEN, G.; SOLBACH, W. Neutrophil granulocytes--Trojan horses for Leishmania major and other intracellular microbes? Trends Microbiol, v. 11, n. 5, p. 210-4, May 2003. ISSN 0966-842X (Print)

0966-842X (Linking). Disponível em: < http://www.ncbi.nlm.nih.gov/pubmed/12781523 >.

LAUFS, H. et al. Intracellular survival of Leishmania major in neutrophil granulocytes after uptake in the absence of heat-labile serum factors. Infect Immun, v. 70, n. 2, p. 826-35, Feb 2002. ISSN 0019-9567 (Print)

0019-9567 (Linking). Disponível em: < http://www.ncbi.nlm.nih.gov/pubmed/11796617>.

LECINE, P. et al. The NOD2-RICK complex signals from the plasma membrane. J Biol Chem, v. 282, n. 20, p. 15197-207, May 18 2007. ISSN 0021-9258 (Print)

0021-9258 (Linking). Disponível em: < http://www.ncbi.nlm.nih.gov/pubmed/17355968 >.

LEGRAND-POELS, S. et al. Modulation of Nod2-dependent NF-kappaB signaling by the actin cytoskeleton. J Cell Sci, v. 120, n. Pt 7, p. 1299-310, Apr 1 2007. ISSN 0021-9533 (Print)

0021-9533 (Linking). Disponível em: < http://www.ncbi.nlm.nih.gov/pubmed/17356065 >.

LEMAITRE, B. et al. The dorsoventral regulatory gene cassette spatzle/Toll/cactus controls the potent antifungal response in Drosophila adults. Cell, v. 86, n. 6, p. 973-83, Sep 20 1996. ISSN 0092-8674 (Print)

0092-8674 (Linking). Disponível em: < http://www.ncbi.nlm.nih.gov/pubmed/8808632 >.

LEON, B.; LOPEZ-BRAVO, M.; ARDAVIN, C. Monocyte-derived dendritic cells formed at the infection site control the induction of protective $\mathrm{T}$ helper 1 responses against Leishmania. Immunity, v. 26, n. 4, p. 519-31, Apr 2007. ISSN 1074-7613 (Print)

1074-7613 (Linking). Disponível em: < http://www.ncbi.nlm.nih.gov/pubmed/17412618 >.

LIESE, J.; SCHLEICHER, U.; BOGDAN, C. The innate immune response against Leishmania parasites. Immunobiology, v. 213, n. 3-4, p. 377-87, 2008. ISSN 0171-2985 (Print)

0171-2985 (Linking). Disponível em: < http://www.ncbi.nlm.nih.gov/pubmed/18406382 >.

LIEW, F. Y. et al. Tumour necrosis factor (TNF alpha) in leishmaniasis. I. TNF alpha mediates host protection against cutaneous leishmaniasis. Immunology, v. 69, n. 4, p. 570-3, Apr 1990. ISSN 0019-2805 (Print) 
0019-2805 (Linking). Disponível em: < http://www.ncbi.nlm.nih.gov/pubmed/2335376>.

LIEW, F. Y.; WEI, X. Q.; PROUDFOOT, L. Cytokines and nitric oxide as effector molecules against parasitic infections. Philos Trans R Soc Lond B Biol Sci, v. 352, n. 1359, p. 1311-5, Sep 29 1997. ISSN 0962-8436 (Print)

0962-8436 (Linking). Disponível em: < http://www.ncbi.nlm.nih.gov/pubmed/9355122 >.

LIMA-JUNIOR, D. S. et al. Inflammasome-derived IL-1beta production induces nitric oxidemediated resistance to Leishmania. Nat Med, v. 19, n. 7, p. 909-15, Jul 2013. ISSN 1546-170X (Electronic)

1078-8956 (Linking). Disponível em: < http://www.ncbi.nlm.nih.gov/pubmed/23749230 > .

LIPINSKI, S. et al. RNAi screening identifies mediators of NOD2 signaling: implications for spatial specificity of MDP recognition. Proc Natl Acad Sci U S A, v. 109, n. 52, p. 21426-31, Dec 26 2012. ISSN 1091-6490 (Electronic)

0027-8424 (Linking). Disponível em: < http://www.ncbi.nlm.nih.gov/pubmed/23213202 >.

LIU, D.; RHEBERGEN, A. M.; EISENBARTH, S. C. Licensing Adaptive Immunity by NODLike Receptors. Front Immunol, v. 4, p. 486, 2013. ISSN 1664-3224 (Electronic)

1664-3224 (Linking). Disponível em: < http://www.ncbi.nlm.nih.gov/pubmed/24409181 >.

LOPEZ KOSTKA, S. et al. IL-17 promotes progression of cutaneous leishmaniasis in susceptible mice. J Immunol, v. 182, n. 5, p. 3039-46, Mar 1 2009. ISSN 1550-6606 (Electronic)

0022-1767 (Linking). Disponível em: < http://www.ncbi.nlm.nih.gov/pubmed/19234200 >.

MALDONADO-LOPEZ, R. et al. Cytokines regulate the capacity of CD8alpha(+) and CD8alpha(-) dendritic cells to prime Th1/Th2 cells in vivo. J Immunol, v. 167, n. 8, p. 4345-50, Oct 15 2001. ISSN 0022-1767 (Print)

0022-1767 (Linking). Disponível em: < http://www.ncbi.nlm.nih.gov/pubmed/11591758 >.

MARETTI-MIRA, A. C. et al. Transcriptome patterns from primary cutaneous Leishmania braziliensis infections associate with eventual development of mucosal disease in humans. PLoS Negl Trop Dis, v. 6, n. 9, p. e1816, 2012. ISSN 1935-2735 (Electronic)

1935-2727 (Linking). Disponível em: < http://www.ncbi.nlm.nih.gov/pubmed/23029578 >.

MARTINEZ-LOPEZ, M. et al. Batf3-dependent CD103+ dendritic cells are major producers of IL-12 that drive local Th1 immunity against Leishmania major infection in mice. Eur $\mathbf{J}$

Immunol, v. 45, n. 1, p. 119-29, Jan 2015. ISSN 1521-4141 (Electronic)

0014-2980 (Linking). Disponível em: < http://www.ncbi.nlm.nih.gov/pubmed/25312824 >.

MARTINON, F. et al. Identification of bacterial muramyl dipeptide as activator of the NALP3/cryopyrin inflammasome. Curr Biol, v. 14, n. 21, p. 1929-34, Nov 9 2004. ISSN 09609822 (Print)

0960-9822 (Linking). Disponível em: < http://www.ncbi.nlm.nih.gov/pubmed/15530394 >. 
MARTINON, F.; BURNS, K.; TSCHOPP, J. The inflammasome: a molecular platform triggering activation of inflammatory caspases and processing of proIL-beta. Mol Cell, v. 10, $\mathrm{n}$. 2, p. 417-26, Aug 2002. ISSN 1097-2765 (Print)

1097-2765 (Linking). Disponível em: < http://www.ncbi.nlm.nih.gov/pubmed/12191486 >.

MASHAYEKHI, M. et al. CD8alpha(+) dendritic cells are the critical source of interleukin-12 that controls acute infection by Toxoplasma gondii tachyzoites. Immunity, v. 35, n. 2, p. 249 59, Aug 26 2011. ISSN 1097-4180 (Electronic)

1074-7613 (Linking). Disponível em: < http://www.ncbi.nlm.nih.gov/pubmed/21867928>.

MAURICIO, I. L.; STOTHARD, J. R.; MILES, M. A. The strange case of Leishmania chagasi. Parasitol Today, v. 16, n. 5, p. 188-9, May 2000. ISSN 0169-4758 (Print)

0169-4758 (Linking). Disponível em: < http://www.ncbi.nlm.nih.gov/pubmed/10782075 >.

MCCULLY, M. L. et al. Receptor-interacting protein-2 deficiency delays macrophage migration and increases intracellular infection during peritoneal dialysis-associated peritonitis. Am J Nephrol, v. 28, n. 6, p. 879-89, 2008. ISSN 1421-9670 (Electronic)

0250-8095 (Linking). Disponível em: < http://www.ncbi.nlm.nih.gov/pubmed/18566542 >.

MEAGHER, L. C. et al. Phagocytosis of apoptotic neutrophils does not induce macrophage release of thromboxane B2. J Leukoc Biol, v. 52, n. 3, p. 269-73, Sep 1992. ISSN 0741-5400 (Print)

0741-5400 (Linking). Disponível em: < http://www.ncbi.nlm.nih.gov/pubmed/1522386 >.

MEBIUS, R. E.; KRAAL, G. Structure and function of the spleen. Nat Rev Immunol, v. 5, n. 8, p. 606-16, Aug 2005. ISSN 1474-1733 (Print)

1474-1733 (Linking). Disponível em: < http://www.ncbi.nlm.nih.gov/pubmed/16056254 >.

MEDZHITOV, R. Toll-like receptors and innate immunity. Nat Rev Immunol, v. 1, n. 2, p. 135-45, Nov 2001. ISSN 1474-1733 (Print)

1474-1733 (Linking). Disponível em: < http://www.ncbi.nlm.nih.gov/pubmed/11905821 >.

MEREDITH, M. M. et al. Expression of the zinc finger transcription factor zDC (Zbtb46, Btbd4) defines the classical dendritic cell lineage. J Exp Med, v. 209, n. 6, p. 1153-65, Jun 4 2012. ISSN 1540-9538 (Electronic)

0022-1007 (Linking). Disponível em: < http://www.ncbi.nlm.nih.gov/pubmed/22615130 >.

MEYLAN, E.; TSCHOPP, J.; KARIN, M. Intracellular pattern recognition receptors in the host response. Nature, v. 442, n. 7098, p. 39-44, Jul 6 2006. ISSN 1476-4687 (Electronic)

0028-0836 (Linking). Disponível em: < http://www.ncbi.nlm.nih.gov/pubmed/16823444 >.

MIRALLES, G. D. et al. Th1 and Th2 cell-associated cytokines in experimental visceral leishmaniasis. Infect Immun, v. 62, n. 3, p. 1058-63, Mar 1994. ISSN 0019-9567 (Print) 0019-9567 (Linking). Disponível em: < http://www.ncbi.nlm.nih.gov/pubmed/8112840 > 
MOLL, H. et al. Langerhans cells transport Leishmania major from the infected skin to the draining lymph node for presentation to antigen-specific T cells. Eur J Immunol, v. 23, n. 7, p. 1595-601, Jul 1993. ISSN 0014-2980 (Print)

0014-2980 (Linking). Disponível em: < http://www.ncbi.nlm.nih.gov/pubmed/8325337 >

MOREIRA, L. O.; ZAMBONI, D. S. NOD1 and NOD2 Signaling in Infection and Inflammation. Front Immunol, v. 3, p. 328，2012. ISSN 1664-3224 (Electronic)

1664-3224 (Linking). Disponível em: < http://www.ncbi.nlm.nih.gov/pubmed/23162548 >.

MORENO, E. C. et al. Risk factors for Leishmania chagasi infection in an urban area of Minas Gerais State. Rev Soc Bras Med Trop, v. 38, n. 6, p. 456-63, Nov-Dec 2005. ISSN 0037-8682 (Print)

0037-8682 (Linking). Disponível em: < http://www.ncbi.nlm.nih.gov/pubmed/16410918>.

MOTTA, V. et al. NOD-like receptors: versatile cytosolic sentinels. Physiol Rev, v. 95, n. 1, p. 149-78, Jan 2015. ISSN 1522-1210 (Electronic)

0031-9333 (Linking). Disponível em: < http://www.ncbi.nlm.nih.gov/pubmed/25540141 >.

MURRAY, H. W.; RUBIN, B. Y.; ROTHERMEL, C. D. Killing of intracellular Leishmania donovani by lymphokine-stimulated human mononuclear phagocytes. Evidence that interferongamma is the activating lymphokine. J Clin Invest, v. 72, n. 4, p. 1506-10, Oct 1983. ISSN 0021-9738 (Print)

0021-9738 (Linking). Disponível em: < http://www.ncbi.nlm.nih.gov/pubmed/6415111 >.

NAKAMURA, N. et al. Endosomes are specialized platforms for bacterial sensing and NOD2 signalling. Nature, v. 509, n. 7499, p. 240-4, May 8 2014. ISSN 1476-4687 (Electronic)

0028-0836 (Linking). Disponível em: < http://www.ncbi.nlm.nih.gov/pubmed/24695226 >.

NASCIMENTO, M. S. et al. Interleukin 17A acts synergistically with interferon gamma to promote protection against Leishmania infantum infection. J Infect Dis, v. 211, n. 6, p. 1015-26, Mar 15 2015. ISSN 1537-6613 (Electronic)

0022-1899 (Linking). Disponível em: < http://www.ncbi.nlm.nih.gov/pubmed/25274569 >.

NETEA, M. G. et al. Nucleotide-binding oligomerization domain-2 modulates specific TLR pathways for the induction of cytokine release. J Immunol, v. 174, n. 10, p. 6518-23, May 15 2005. ISSN 0022-1767 (Print)

0022-1767 (Linking). Disponível em: < http://www.ncbi.nlm.nih.gov/pubmed/15879155 >.

NOBEN-TRAUTH, N. et al. The relative contribution of IL-4 receptor signaling and IL-10 to susceptibility to Leishmania major. J Immunol, v. 170, n. 10, p. 5152-8, May 15 2003. ISSN 0022-1767 (Print)

0022-1767 (Linking). Disponível em: < http://www.ncbi.nlm.nih.gov/pubmed/12734362 >. 
NOLTE, M. A. et al. A conduit system distributes chemokines and small blood-borne molecules through the splenic white pulp. J Exp Med, v. 198, n. 3, p. 505-12, Aug 42003. ISSN 0022-1007 (Print)

0022-1007 (Linking). Disponível em: < http://www.ncbi.nlm.nih.gov/pubmed/12900524 >.

O'SHEA, J. J.; PAUL, W. E. Mechanisms underlying lineage commitment and plasticity of helper CD4+ T cells. Science, v. 327, n. 5969, p. 1098-102, Feb 26 2010. ISSN 1095-9203 (Electronic)

0036-8075 (Linking). Disponível em: < http://www.ncbi.nlm.nih.gov/pubmed/20185720>.

OGURA, Y. et al. Nod2, a Nod1/Apaf-1 family member that is restricted to monocytes and activates NF-kappaB. J Biol Chem, v. 276, n. 7, p. 4812-8, Feb 16 2001. ISSN 0021-9258 (Print)

0021-9258 (Linking). Disponível em: < http://www.ncbi.nlm.nih.gov/pubmed/11087742 >.

OGURA, Y. et al. Expression of NOD2 in Paneth cells: a possible link to Crohn's ileitis. Gut, v. 52, n. 11, p. 1591-7, Nov 2003. ISSN 0017-5749 (Print)

0017-5749 (Linking). Disponível em: < http://www.ncbi.nlm.nih.gov/pubmed/14570728 >.

OKAMOTO, K. et al. IkappaBzeta regulates $\mathrm{T}(\mathrm{H}) 17$ development by cooperating with ROR nuclear receptors. Nature, v. 464, n. 7293, p. 1381-5, Apr 29 2010. ISSN 1476-4687 (Electronic)

0028-0836 (Linking). Disponível em: < http://www.ncbi.nlm.nih.gov/pubmed/20383124 >.

OPITZ, B. et al. Nod1-mediated endothelial cell activation by Chlamydophila pneumoniae.

Circ Res, v. 96, n. 3, p. 319-26, Feb 18 2005. ISSN 1524-4571 (Electronic)

0009-7330 (Linking). Disponível em: < http://www.ncbi.nlm.nih.gov/pubmed/15653568 >.

OPITZ, B. et al. Nucleotide-binding oligomerization domain proteins are innate immune receptors for internalized Streptococcus pneumoniae. J Biol Chem, v. 279, n. 35, p. 36426-32, Aug 27 2004. ISSN 0021-9258 (Print)

0021-9258 (Linking). Disponível em: < http://www.ncbi.nlm.nih.gov/pubmed/15215247>.

PARK, J. H. et al. RICK/RIP2 mediates innate immune responses induced through Nod1 and Nod2 but not TLRs. J Immunol, v. 178, n. 4, p. 2380-6, Feb 15 2007. ISSN 0022-1767 (Print)

0022-1767 (Linking). Disponível em: < http://www.ncbi.nlm.nih.gov/pubmed/17277144 >.

PAUN, A. et al. Critical role of IRF-5 in the development of T helper 1 responses to Leishmania donovani infection. PLoS Pathog, v. 7, n. 1, p. e1001246, 2011. ISSN 1553-7374 (Electronic)

1553-7366 (Linking). Disponível em: < http://www.ncbi.nlm.nih.gov/pubmed/21253574 >.

PEACOCK, C. S. et al. Comparative genomic analysis of three Leishmania species that cause diverse human disease. Nat Genet, v. 39, n. 7, p. 839-47, Jul 2007. ISSN 1061-4036 (Print) 
1061-4036 (Linking). Disponível em: < http://www.ncbi.nlm.nih.gov/pubmed/17572675 >.

PEARSON, R. D.; STEIGBIGEL, R. T. Phagocytosis and killing of the protozoan Leishmania donovani by human polymorphonuclear leukocytes. J Immunol, v. 127, n. 4, p. 1438-43, Oct 1981. ISSN 0022-1767 (Print)

0022-1767 (Linking). Disponível em: < http://www.ncbi.nlm.nih.gov/pubmed/7276565 >.

PEDRA, J. H. et al. ASC/PYCARD and caspase-1 regulate the IL-18/IFN-gamma axis during Anaplasma phagocytophilum infection. J Immunol, v. 179, n. 7, p. 4783-91, Oct 1 2007. ISSN 0022-1767 (Print)

0022-1767 (Linking). Disponível em: < http://www.ncbi.nlm.nih.gov/pubmed/17878377>.

PEDROSA, C. M.; DA ROCHA, E. M. [Clinical and epidemiological aspects of visceral leishmaniasis in children up to 15 years of age in Alagoas, Brasil]. Rev Soc Bras Med Trop, v. 37, n. 4, p. 300-4, Jul-Aug 2004. ISSN 0037-8682 (Print)

0037-8682 (Linking). Disponível em: < http://www.ncbi.nlm.nih.gov/pubmed/15334262 >.

PERSSON, E. K. et al. IRF4 transcription-factor-dependent CD103(+)CD11b(+) dendritic cells drive mucosal T helper 17 cell differentiation. Immunity, v. 38, n. 5, p. 958-69, May 232013. ISSN 1097-4180 (Electronic)

1074-7613 (Linking). Disponível em: < http://www.ncbi.nlm.nih.gov/pubmed/23664832 >.

PETERS, N. C. et al. In vivo imaging reveals an essential role for neutrophils in leishmaniasis transmitted by sand flies. Science, v. 321, n. 5891, p. 970-4, Aug 15 2008. ISSN 1095-9203 (Electronic)

0036-8075 (Linking). Disponível em: < http://www.ncbi.nlm.nih.gov/pubmed/18703742 >.

PETERS, W. et al. Leishmania infecting man and wild animals in Saudi Arabia. 8. The influence of prior infection with Leishmania arabica on challenge with L. major in man. Trans R Soc Trop Med Hyg, v. 84, n. 5, p. 681-9, Sep-Oct 1990. ISSN 0035-9203 (Print)

0035-9203 (Linking). Disponível em: < http://www.ncbi.nlm.nih.gov/pubmed/2126153>.

PITTA, M. G. et al. IL-17 and IL-22 are associated with protection against human kala azar caused by Leishmania donovani. J Clin Invest, v. 119, n. 8, p. 2379-87, Aug 2009. ISSN 15588238 (Electronic)

0021-9738 (Linking). Disponível em: < http://www.ncbi.nlm.nih.gov/pubmed/19620772 >.

PRINA, E. et al. Dendritic cells as host cells for the promastigote and amastigote stages of Leishmania amazonensis: the role of opsonins in parasite uptake and dendritic cell maturation. $\mathbf{J}$ Cell Sci, v. 117, n. Pt 2, p. 315-25, Jan 15 2004. ISSN 0021-9533 (Print)

0021-9533 (Linking). Disponível em: < http://www.ncbi.nlm.nih.gov/pubmed/14657281 >.

REITHINGER, R. et al. Cutaneous leishmaniasis. Lancet Infect Dis, v. 7, n. 9, p. 581-96, Sep 2007. ISSN 1473-3099 (Print)

1473-3099 (Linking). Disponível em: < http://www.ncbi.nlm.nih.gov/pubmed/17714672 >. 
REYNOLDS, J. M. et al. Toll-like receptor 2 signaling in CD4(+) T lymphocytes promotes T helper 17 responses and regulates the pathogenesis of autoimmune disease. Immunity, v. 32, n. 5, p. 692-702, May 28 2010. ISSN 1097-4180 (Electronic)

1074-7613 (Linking). Disponível em: < http://www.ncbi.nlm.nih.gov/pubmed/20434372 >

RISSOAN, M. C. et al. Reciprocal control of T helper cell and dendritic cell differentiation. Science, v. 283, n. 5405, p. $1183-6$, Feb 19 1999. ISSN 0036-8075 (Print)

0036-8075 (Linking). Disponível em: < http://www.ncbi.nlm.nih.gov/pubmed/10024247>.

RITTER, M. et al. Schistosoma mansoni triggers Dectin-2, which activates the Nlrp3 inflammasome and alters adaptive immune responses. Proc Natl Acad Sci U S A, v. 107, n. 47, p. 20459-64, Nov 23 2010. ISSN 1091-6490 (Electronic)

0027-8424 (Linking). Disponível em: < http://www.ncbi.nlm.nih.gov/pubmed/21059925 >.

ROBINSON, M. D.; MCCARTHY, D. J.; SMYTH, G. K. edgeR: a Bioconductor package for differential expression analysis of digital gene expression data. Bioinformatics, v. 26, n. 1, p. 139-40, Jan 1 2010. ISSN 1367-4811 (Electronic)

1367-4803 (Linking). Disponível em: < http://www.ncbi.nlm.nih.gov/pubmed/19910308 >.

ROSS, R. Further Notes on Leishman's Bodies. Br Med J, v. 2, n. 2239, p. 1401, Nov 281903. ISSN 0007-1447 (Print)

0007-1447 (Linking). Disponível em: < http://www.ncbi.nlm.nih.gov/pubmed/20761210 >.

ROSSI, M.; YOUNG, J. W. Human dendritic cells: potent antigen-presenting cells at the crossroads of innate and adaptive immunity. J Immunol, v. 175, n. 3, p. 1373-81, Aug 12005. ISSN 0022-1767 (Print)

0022-1767 (Linking). Disponível em: < http://www.ncbi.nlm.nih.gov/pubmed/16034072 >.

SABBAH, A. et al. Activation of innate immune antiviral responses by Nod2. Nat Immunol, v. 10, n. 10, p. 1073-80, Oct 2009. ISSN 1529-2916 (Electronic)

1529-2908 (Linking). Disponível em: < http://www.ncbi.nlm.nih.gov/pubmed/19701189>.

SACKS, D.; NOBEN-TRAUTH, N. The immunology of susceptibility and resistance to Leishmania major in mice. Nat Rev Immunol, v. 2, n. 11, p. 845-58, Nov 2002. ISSN 14741733 (Print)

1474-1733 (Linking). Disponível em: < http://www.ncbi.nlm.nih.gov/pubmed/12415308>.

SACKS, D. L. et al. An analysis of T cell responsiveness in Indian kala-azar. J Immunol, v. 138, n. 3, p. 908-13, Feb 1 1987. ISSN 0022-1767 (Print)

0022-1767 (Linking). Disponível em: < http://www.ncbi.nlm.nih.gov/pubmed/3100620>.

SACRAMENTO, L. et al. Toll-Like Receptor 9 Signaling in Dendritic Cells Regulates Neutrophil Recruitment to Inflammatory Foci following Leishmania infantum Infection. Infect Immun, v. 83, n. 12, p. 4604-16, Dec 2015. ISSN 1098-5522 (Electronic) 
0019-9567 (Linking). Disponível em: < http://www.ncbi.nlm.nih.gov/pubmed/26371124 >.

SADLOVA, J. et al. The stage-regulated HASPB and SHERP proteins are essential for differentiation of the protozoan parasite Leishmania major in its sand fly vector, Phlebotomus papatasi. Cell Microbiol, v. 12, n. 12, p. 1765-79, Dec 2010. ISSN 1462-5822 (Electronic)

1462-5814 (Linking). Disponível em: < http://www.ncbi.nlm.nih.gov/pubmed/20636473 >.

SAEED, A. I. et al. TM4: a free, open-source system for microarray data management and analysis. Biotechniques, v. 34, n. 2, p. 374-8, Feb 2003. ISSN 0736-6205 (Print)

0736-6205 (Linking). Disponível em: < http://www.ncbi.nlm.nih.gov/pubmed/12613259>.

SAPOZNIKOV, A. et al. Organ-dependent in vivo priming of naive CD4+, but not CD8+, T cells by plasmacytoid dendritic cells. J Exp Med, v. 204, n. 8, p. 1923-33, Aug 6 2007. ISSN 0022-1007 (Print)

0022-1007 (Linking). Disponível em: < http://www.ncbi.nlm.nih.gov/pubmed/17646404 >.

SATPATHY, A. T. et al. Re(de)fining the dendritic cell lineage. Nat Immunol, v. 13, n. 12, p. 1145-54, Dec 2012. ISSN 1529-2916 (Electronic)

1529-2908 (Linking). Disponível em: < http://www.ncbi.nlm.nih.gov/pubmed/23160217 >.

SCHARTON-KERSTEN, T. et al. IL-12 is required for natural killer cell activation and subsequent T helper 1 cell development in experimental leishmaniasis. J Immunol, v. 154, n. 10, p. 5320-30, May 15 1995. ISSN 0022-1767 (Print)

0022-1767 (Linking). Disponível em: < http://www.ncbi.nlm.nih.gov/pubmed/7730635 >.

SCHIAVONI, G. et al. ICSBP is essential for the development of mouse type I interferonproducing cells and for the generation and activation of CD8alpha $(+)$ dendritic cells. J Exp Med, v. 196, n. 11, p. 1415-25, Dec 2 2002. ISSN 0022-1007 (Print)

0022-1007 (Linking). Disponível em: < http://www.ncbi.nlm.nih.gov/pubmed/12461077>.

SCHLEGEL, P. M. et al. B cells contribute to heterogeneity of IL-17 producing cells in rheumatoid arthritis and healthy controls. PLoS One, v. 8, n. 12, p. e82580, 2013. ISSN 19326203 (Electronic)

1932-6203 (Linking). Disponível em: < http://www.ncbi.nlm.nih.gov/pubmed/24340045 >.

SCHLITZER, A. et al. IRF4 transcription factor-dependent CD11b+ dendritic cells in human and mouse control mucosal IL-17 cytokine responses. Immunity, v. 38, n. 5, p. 970-83, May 23 2013. ISSN 1097-4180 (Electronic)

1074-7613 (Linking). Disponível em: < http://www.ncbi.nlm.nih.gov/pubmed/23706669 >.

SCHRAML, B. U. et al. The AP-1 transcription factor Batf controls T(H)17 differentiation.

Nature, v. 460, n. 7253, p. 405-9, Jul 16 2009. ISSN 1476-4687 (Electronic)

0028-0836 (Linking). Disponível em: < http://www.ncbi.nlm.nih.gov/pubmed/19578362 >. 
SEGURA, E.; AMIGORENA, S. Inflammatory dendritic cells in mice and humans. Trends Immunol, v. 34, n. 9, p. 440-5, Sep 2013. ISSN 1471-4981 (Electronic)

1471-4906 (Linking). Disponível em: < http://www.ncbi.nlm.nih.gov/pubmed/23831267>.

SERBINA, N. V. et al. TNF/iNOS-producing dendritic cells mediate innate immune defense against bacterial infection. Immunity, v. 19, n. 1, p. 59-70, Jul 2003. ISSN 1074-7613 (Print)

1074-7613 (Linking). Disponível em: < http://www.ncbi.nlm.nih.gov/pubmed/12871639>.

SHAW, M. H. et al. NOD-like receptors (NLRs): bona fide intracellular microbial sensors.

Curr Opin Immunol, v. 20, n. 4, p. 377-82, Aug 2008. ISSN 0952-7915 (Print)

0952-7915 (Linking). Disponível em: < http://www.ncbi.nlm.nih.gov/pubmed/18585455 >.

SHAW, M. H. et al. T cell-intrinsic role of Nod2 in promoting type 1 immunity to Toxoplasma gondii. Nat Immunol, v. 10, n. 12, p. 1267-74, Dec 2009. ISSN 1529-2916 (Electronic)

1529-2908 (Linking). Disponível em: < http://www.ncbi.nlm.nih.gov/pubmed/19881508 >.

SHEEL, M. et al. IL-17A-Producing gammadelta T Cells Suppress Early Control of Parasite Growth by Monocytes in the Liver. J Immunol, Nov 4 2015. ISSN 1550-6606 (Electronic)

0022-1767 (Linking). Disponível em: < http://www.ncbi.nIm.nih.gov/pubmed/26538396 >.

SHENDEROV, K. et al. Cord factor and peptidoglycan recapitulate the Th17-promoting adjuvant activity of mycobacteria through mincle/CARD9 signaling and the inflammasome. $\mathbf{J}$

Immunol, v. 190, n. 11, p. 5722-30, Jun 1 2013. ISSN 1550-6606 (Electronic)

0022-1767 (Linking). Disponível em: < http://www.ncbi.nlm.nih.gov/pubmed/23630357 >.

SHI, Y.; EVANS, J. E.; ROCK, K. L. Molecular identification of a danger signal that alerts the immune system to dying cells. Nature, v. 425, n. 6957, p. 516-21, Oct 2 2003. ISSN 1476-4687 (Electronic)

0028-0836 (Linking). Disponível em: < http://www.ncbi.nlm.nih.gov/pubmed/14520412 >.

SHIMADA, K. et al. The NOD/RIP2 pathway is essential for host defenses against Chlamydophila pneumoniae lung infection. PLoS Pathog, v. 5, n. 4, p. e1000379, Apr 2009. ISSN 1553-7374 (Electronic)

1553-7366 (Linking). Disponível em: < http://www.ncbi.nlm.nih.gov/pubmed/19360122 >.

SHIN, S. et al. Type IV secretion-dependent activation of host MAP kinases induces an increased proinflammatory cytokine response to Legionella pneumophila. PLoS Pathog, v. 4, n. 11, p. e1000220, Nov 2008. ISSN 1553-7374 (Electronic)

1553-7366 (Linking). Disponível em: < http://www.ncbi.nlm.nih.gov/pubmed/19043549 >.

SHORTMAN, K.; NAIK, S. H. Steady-state and inflammatory dendritic-cell development. Nat Rev Immunol, v. 7, n. 1, p. 19-30, Jan 2007. ISSN 1474-1733 (Print)

1474-1733 (Linking). Disponível em: < http://www.ncbi.nlm.nih.gov/pubmed/17170756 >. 
SILVA, G. K. et al. Cutting edge: nucleotide-binding oligomerization domain 1-dependent responses account for murine resistance against Trypanosoma cruzi infection. J Immunol, v. 184, n. 3, p. 1148-52, Feb 1 2010. ISSN 1550-6606 (Electronic)

0022-1767 (Linking). Disponível em: < http://www.ncbi.nlm.nih.gov/pubmed/20042586 >.

SILVEIRA, F. T. et al. A prospective study on the dynamics of the clinical and immunological evolution of human Leishmania (L.) infantum chagasi infection in the Brazilian Amazon region. Trans R Soc Trop Med Hyg, v. 104, n. 8, p. 529-35, Aug 2010. ISSN 1878-3503 (Electronic)

0035-9203 (Linking). Disponível em: < http://www.ncbi.nlm.nih.gov/pubmed/20538310 >.

SUZUKI, S. et al. Critical roles of interferon regulatory factor 4 in CD11bhighCD8alphadendritic cell development. Proc Natl Acad Sci U S A, v. 101, n. 24, p. 8981-6, Jun 152004. ISSN 0027-8424 (Print)

0027-8424 (Linking). Disponível em: < http://www.ncbi.nIm.nih.gov/pubmed/15184678>.

TADA, H. et al. Synergistic effect of Nod1 and Nod2 agonists with toll-like receptor agonists on human dendritic cells to generate interleukin-12 and T helper type 1 cells. Infect Immun, v. 73, n. 12, p. 7967-76, Dec 2005. ISSN 0019-9567 (Print)

0019-9567 (Linking). Disponível em: < http://www.ncbi.nlm.nih.gov/pubmed/16299289 >.

TERRAZAS, C. et al. IL-17A promotes susceptibility during experimental visceral leishmaniasis caused by Leishmania donovani. FASEB J, Nov 18 2015. ISSN 1530-6860 (Electronic)

0892-6638 (Linking). Disponível em: < http://www.ncbi.nlm.nih.gov/pubmed/26581600>.

THAKUR, C. P.; MITRA, D. K.; NARAYAN, S. Skewing of cytokine profiles towards T helper cell type 2 response in visceral leishmaniasis patients unresponsive to sodium antimony gluconate. Trans R Soc Trop Med Hyg, v. 97, n. 4, p. 409-12, Jul-Aug 2003. ISSN 0035-9203 (Print)

0035-9203 (Linking). Disponível em: < http://www.ncbi.nlm.nih.gov/pubmed/15259468 >.

THALHOFER, C. J. et al. Leukocytes infiltrate the skin and draining lymph nodes in response to the protozoan Leishmania infantum chagasi. Infect Immun, v. 79, n. 1, p. 108-17, Jan 2011. ISSN 1098-5522 (Electronic)

0019-9567 (Linking). Disponível em: < http://www.ncbi.nlm.nih.gov/pubmed/20937764 >.

TILL, A. et al. A role for membrane-bound CD147 in NOD2-mediated recognition of bacterial cytoinvasion. J Cell Sci, v. 121, n. Pt 4, p. 487-95, Feb 15 2008. ISSN 0021-9533 (Print)

0021-9533 (Linking). Disponível em: < http://www.ncbi.nlm.nih.gov/pubmed/18256385 >.

TING, J. P. et al. The NLR gene family: a standard nomenclature. Immunity, v. 28, n. 3, p. 285-7, Mar 2008. ISSN 1097-4180 (Electronic) 
1074-7613 (Linking). Disponível em: < http://www.ncbi.nlm.nih.gov/pubmed/18341998 >.

TITUS, R. G. et al. A limiting dilution assay for quantifying Leishmania major in tissues of infected mice. Parasite Immunol, v. 7, n. 5, p. 545-55, Sep 1985. ISSN 0141-9838 (Print)

0141-9838 (Linking). Disponível em: < http://www.ncbi.nlm.nih.gov/pubmed/3877902 >.

TRAVASSOS, L. H. et al. Nod proteins link bacterial sensing and autophagy. Autophagy, v. 6, n. 3, p. 409-11, Apr 2010. ISSN 1554-8635 (Electronic)

1554-8627 (Linking). Disponível em: < http://www.ncbi.nlm.nih.gov/pubmed/20200479>.

TRAVASSOS, L. H. et al. Nod1 participates in the innate immune response to Pseudomonas aeruginosa. J Biol Chem, v. 280, n. 44, p. 36714-8, Nov 4 2005. ISSN 0021-9258 (Print)

0021-9258 (Linking). Disponível em: < http://www.ncbi.nlm.nih.gov/pubmed/16150702 >.

TRAVASSOS, L. H. et al. Nod1 and Nod2 direct autophagy by recruiting ATG16L1 to the plasma membrane at the site of bacterial entry. Nat Immunol, v. 11, n. 1, p. 55-62, Jan 2010. ISSN 1529-2916 (Electronic)

1529-2908 (Linking). Disponível em: < http://www.ncbi.nlm.nih.gov/pubmed/19898471 >.

UEHARA, A. et al. Various human epithelial cells express functional Toll-like receptors, NOD1 and NOD2 to produce anti-microbial peptides, but not proinflammatory cytokines. Mol Immunol, v. 44, n. 12, p. 3100-11, May 2007. ISSN 0161-5890 (Print)

0161-5890 (Linking). Disponível em: < http://www.ncbi.nlm.nih.gov/pubmed/17403538 >.

UEHARA, A. et al. Muramyldipeptide and diaminopimelic acid-containing desmuramylpeptides in combination with chemically synthesized Toll-like receptor agonists synergistically induced production of interleukin-8 in a NOD2- and NOD1-dependent manner, respectively, in human monocytic cells in culture. Cell Microbiol, v. 7, n. 1, p. 53-61, Jan 2005. ISSN 1462-5814 (Print)

1462-5814 (Linking). Disponível em: < http://www.ncbi.nlm.nih.gov/pubmed/15617523 >

VAN BEELEN, A. J. et al. Stimulation of the intracellular bacterial sensor NOD2 programs dendritic cells to promote interleukin-17 production in human memory T cells. Immunity, v. 27, n. 4, p. 660-9, Oct 2007. ISSN 1074-7613 (Print)

1074-7613 (Linking). Disponível em: < http://www.ncbi.nlm.nih.gov/pubmed/17919942 >.

VAN, D., V, GRESNIGT, M.S., KULLBERG, B.J., VAN DER MEER, J.W., JOOSTEN, L.A., NETEA, M.G. Th17 responses and host defense against microorganisms: an overview. BMB. Rep, v. 42, p. 776-787, 2009.

VAN DE VEERDONK, F. L. et al. The inflammasome drives protective Th1 and Th17 cellular responses in disseminated candidiasis. Eur J Immunol, v. 41, n. 8, p. 2260-8, Aug 2011. ISSN 1521-4141 (Electronic)

0014-2980 (Linking). Disponível em: < http://www.ncbi.nlm.nih.gov/pubmed/21681738 >. 
VAN ZANDBERGEN, G. et al. Cutting edge: neutrophil granulocyte serves as a vector for Leishmania entry into macrophages. J Immunol, v. 173, n. 11, p. 6521-5, Dec 1 2004. ISSN 0022-1767 (Print)

0022-1767 (Linking). Disponível em: < http://www.ncbi.nlm.nih.gov/pubmed/15557140 >.

VARGAS-INCHAUSTEGUI, D. A.; XIN, L.; SOONG, L. Leishmania braziliensis infection induces dendritic cell activation, ISG15 transcription, and the generation of protective immune responses. J Immunol, v. 180, n. 11, p. 7537-45, Jun 1 2008. ISSN 0022-1767 (Print)

0022-1767 (Linking). Disponível em: < http://www.ncbi.nlm.nih.gov/pubmed/18490754 >.

VELDHOEN, M. et al. The aryl hydrocarbon receptor links TH17-cell-mediated autoimmunity to environmental toxins. Nature, v. 453, n. 7191, p. 106-9, May 1 2008. ISSN 1476-4687 (Electronic)

0028-0836 (Linking). Disponível em: < http://www.ncbi.nlm.nih.gov/pubmed/18362914 >.

VIALA, J. et al. Nod1 responds to peptidoglycan delivered by the Helicobacter pylori cag pathogenicity island. Nat Immunol, v. 5, n. 11, p. 1166-74, Nov 2004. ISSN 1529-2908 (Print)

1529-2908 (Linking). Disponível em: < http://www.ncbi.nlm.nih.gov/pubmed/15489856>.

VOLPE, E. et al. A critical function for transforming growth factor-beta, interleukin 23 and proinflammatory cytokines in driving and modulating human $\mathrm{T}(\mathrm{H})-17$ responses. Nat Immunol, v. 9, n. 6, p. 650-7, Jun 2008. ISSN 1529-2916 (Electronic)

1529-2908 (Linking). Disponível em: < http://www.ncbi.nlm.nih.gov/pubmed/18454150>.

WATANABE, T. et al. NOD2 is a negative regulator of Toll-like receptor 2-mediated T helper type 1 responses. Nat Immunol, v. 5, n. 8, p. 800-8, Aug 2004. ISSN 1529-2908 (Print)

1529-2908 (Linking). Disponível em: < http://www.ncbi.nlm.nih.gov/pubmed/15220916>.

WELTER-STAHL, L. et al. Stimulation of the cytosolic receptor for peptidoglycan, Nod1, by infection with Chlamydia trachomatis or Chlamydia muridarum. Cell Microbiol, v. 8, n. 6, p. 1047-57, Jun 2006. ISSN 1462-5814 (Print)

1462-5814 (Linking). Disponível em: < http://www.ncbi.nIm.nih.gov/pubmed/16681844 >.

WENZEL, U. A. et al. CD103+ CD11b+ Dendritic Cells Induce Th17 T Cells in Muc2Deficient Mice with Extensively Spread Colitis. PLoS One, v. 10, n. 6, p. e0130750, 2015. ISSN 1932-6203 (Electronic)

1932-6203 (Linking). Disponível em: < http://www.ncbi.nlm.nih.gov/pubmed/26121642>.

WERTS, C. et al. Nod1 and Nod2 induce CCL5/RANTES through the NF-kappaB pathway.

Eur J Immunol, v. 37, n. 9, p. 2499-508, Sep 2007. ISSN 0014-2980 (Print)

0014-2980 (Linking). Disponível em: < http://www.ncbi.nlm.nih.gov/pubmed/17705131 >.

WILMANSKI, J. M.; PETNICKI-OCWIEJA, T.; KOBAYASHI, K. S. NLR proteins: integral members of innate immunity and mediators of inflammatory diseases. J Leukoc Biol, v. 83, n. 1, p. 13-30, Jan 2008. ISSN 0741-5400 (Print) 
0741-5400 (Linking). Disponível em: < http://www.ncbi.nlm.nih.gov/pubmed/17875812 >.

WILSON, M. E.; JERONIMO, S. M.; PEARSON, R. D. Immunopathogenesis of infection with the visceralizing Leishmania species. Microb Pathog, v. 38, n. 4, p. 147-60, Apr 2005. ISSN 0882-4010 (Print)

0882-4010 (Linking). Disponível em: < http://www.ncbi.nIm.nih.gov/pubmed/15797810>.

WINDHEIM, M. et al. Molecular mechanisms involved in the regulation of cytokine production by muramyl dipeptide. Biochem J, v. 404, n. 2, p. 179-90, Jun 1 2007. ISSN 14708728 (Electronic)

0264-6021 (Linking). Disponível em: < http://www.ncbi.nlm.nih.gov/pubmed/17348859 >.

YANG, X. O. et al. STAT3 regulates cytokine-mediated generation of inflammatory helper T cells. J Biol Chem, v. 282, n. 13, p. 9358-63, Mar 30 2007. ISSN 0021-9258 (Print)

0021-9258 (Linking). Disponível em: < http://www.ncbi.nlm.nih.gov/pubmed/17277312>.

YOSEF, N. et al. Dynamic regulatory network controlling TH17 cell differentiation. Nature, v. 496, n. 7446, p. 461-8, Apr 25 2013. ISSN 1476-4687 (Electronic)

0028-0836 (Linking). Disponível em: < http://www.ncbi.nlm.nih.gov/pubmed/23467089 >.

ZAMBONI, D. S.; LIMA-JUNIOR, D. S. Inflammasomes in host response to protozoan parasites. Immunol Rev, v. 265, n. 1, p. 156-71, May 2015. ISSN 1600-065X (Electronic)

0105-2896 (Linking). Disponível em: < http://www.ncbi.nlm.nih.gov/pubmed/25879291 >.

ZHANG, F.; MENG, G.; STROBER, W. Interactions among the transcription factors Runx1, RORgammat and Foxp3 regulate the differentiation of interleukin 17-producing T cells. Nat Immunol, v. 9, n. 11, p. 1297-306, Nov 2008. ISSN 1529-2916 (Electronic)

1529-2908 (Linking). Disponível em: < http://www.ncbi.nlm.nih.gov/pubmed/18849990 > .

ZHANG, W. W.; MATLASHEWSKI, G. Immunization with a Toll-like receptor 7 and/or 8 agonist vaccine adjuvant increases protective immunity against Leishmania major in BALB/c mice. Infect Immun, v. 76, n. 8, p. 3777-83, Aug 2008. ISSN 1098-5522 (Electronic)

0019-9567 (Linking). Disponível em: < http://www.ncbi.nlm.nih.gov/pubmed/18474642 >.

ZILBAUER, M. et al. A major role for intestinal epithelial nucleotide oligomerization domain 1 (NOD1) in eliciting host bactericidal immune responses to Campylobacter jejuni. Cell Microbiol, v. 9, n. 10, p. 2404-16, Oct 2007. ISSN 1462-5814 (Print)

1462-5814 (Linking). Disponível em: < http://www.ncbi.nlm.nih.gov/pubmed/17521327 >.

ZINK, S. D. et al. The Dot/Icm type IV secretion system of Legionella pneumophila is essential for the induction of apoptosis in human macrophages. Infect Immun, v. 70, n. 3, p. 1657-63, Mar 2002. ISSN 0019-9567 (Print)

0019-9567 (Linking). Disponível em: < http://www.ncbi.nlm.nih.gov/pubmed/11854262 > 
SINAN-SVS-MS, 2014. Sistema de Vigilância em Saúde - Ministério da Saúde. Situação epidemiológica da leishmaniose visceral no Brasil, março 2014.

http://portalsaude.saude.gov.br/index.php/o-ministerio/principal/leia-mais-o-ministerio/726secretaria-svs/vigilancia-de-a-a-z/leishmaniose-visceral-lv/11334-situacao-epidemiologica$\underline{\text { dados }}$

WHO. World Health Organization. Leishmaniasis, Fact sheet $N^{\circ} 375$, February, 2015:

\section{http://www.who.int/mediacentre/factsheets/fs375/en/}

WHO. World Health Organization. Leishmaniasis: epidemiology and access to medicines.

Update: 2012.

http://www.who.int/leishmaniasis/resources/leishmaniasis_epidemiology_access to medicine/e $\underline{\mathrm{n} /}$

WHO. World Health Organization. Leishmaniasis: Visceral leishmaniasis. Accessed on: 2015 http://www.who.int/leishmaniasis/visceral_leishmaniasis/en/index.html

http://www.bioinformatics.babraham.ac.uk/projects/fastqc/

Anders S. HTSeq: Analysing high-throughput sequencing data with Python. http://wwwhuber.embl.de/users/anders/HTSeq/doc/overview.html. 
X. Anexos 


\section{Anexo 1 - Certificado de aprovação pelo Comitê de Ética Humano}

Plataforma Brasil

http://aplicacao.saude.gov.br/plataformabrasil/visao/pesquisad.

$$
\begin{aligned}
& \text { Saride } \\
& \text { A } \text { principal }^{\text {central de suporte } x} \text { sair } \\
& \text { Cadastros } \\
& \text { Roque Pacheco de Almeida - Pesquisodor [ V2 } 21
\end{aligned}
$$

Voct esta em: Pesquisador > Gerir Pesquisa > Detalhar Projeto de Pesquilsa

DETALHAR PROJETO DE PESQUISA

Dados do Projeto de Pesquise

Titulo da Pesquisa: Infuencla da Interaçăo entre os Agentes Infecclosos e Hospedelros na Patogenese de Doenças Inteocsosas e Parastarlas

Pesquisador: Roque Pacheco de Almelda

Area Tematica: Pesqulsas com coordenaçăo e/ou patrocinio originados fora do Brabll, excetuadas aquelas com copatrocinlo do Governo Brastelro:

Veraas: 1

CAAE: 04587312.2 .0000 .005

Submetido em: 28/08/2012

Instittulça Proponente: FUNDACAO UNIVERSIDADE FEDERAL DE SERGIPE

\begin{tabular}{|c|c|c|c|}
\hline \multicolumn{4}{|l|}{ Documentos Postados do Projeto } \\
\hline Tipo Documento & situaçao & Arquivo & Postagem \\
\hline Pareoer Consubstanclado do CEP & A & Fin PARECER CONSUBSTANCIADO CEP 101506.pdr & 19/09/2012 09:42:02 \\
\hline Informaçбes Bassicas do Projeto & A & 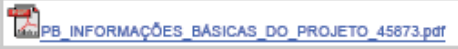 & $28 / 08 / 201211: 44: 16$ \\
\hline Intertace REBEC & A & PB XML INTERFACE REBEC.Xm! & $28 / 08 / 201211: 44: 16$ \\
\hline Folha de Rosto & A & Fin Folla de rosto assinada pdr & $28 / / 08 / 201211: 42: 52$ \\
\hline Outros & A & 团 & $28 / 08 / 201211-24: 45$ \\
\hline
\end{tabular}

situaçà: Aprovado

\begin{tabular}{|c|c|c|c|}
\hline \multicolumn{4}{|l|}{ Documentos Postados da Notrilcaçao } \\
\hline Tlpo Documento & situaçao & Arquivo & Postagem \\
\hline Parecer Consubstanclado do CEP & A & PA PARECER CONSUBSTANCIADO CEP 681184.potr & 10106/2014 09:14:33 \\
\hline outros & A & 回- & $15 / 05 / 201422: 41: 24$ \\
\hline
\end{tabular}

Locallzaçąo atual do Projeto: Pesquisador Responsavel

\begin{tabular}{|c|c|c|c|c|}
\hline \multicolumn{5}{|l|}{ Tramitaçâ: } \\
\hline CEP Tramilte & situaçào & Data Tramitte & Parecer & Informaçסess \\
\hline $\begin{array}{l}\text { Unlversidade Federal de Sergipe } \\
- \text { HU / UFS" }^{\text {a }}\end{array}$ & $\begin{array}{l}\text { Submetido para avallaçăo do } \\
\text { CEP }\end{array}$ & $28 / 08 / 2012$ & & \\
\hline $\begin{array}{l}\text { Hospltal Universttario de Aracaju' } \\
\text { Unlversidade Federal de Sergipe' } \\
\text { HU-UFS }\end{array}$ & $\begin{array}{l}\text { Submetido para avallaç̧o do } \\
\text { CEP }\end{array}$ & $28 / 08 / 2012$ & & \\
\hline $\begin{array}{l}\text { Unlversidade Federal de Sergipe } \\
- \text { HU / UFS" }^{-}\end{array}$ & Aceltaçăo do PP & $29 / 08 / 2012$ & & \\
\hline $\begin{array}{l}\text { Hospttal Unwersttarlo de Aracajus } \\
\text { Unlversidade Federal de Sergipe/ } \\
\text { HU-UFS }\end{array}$ & Acettaçăo do PP & $29 / 08 / 2012$ & & \\
\hline $\begin{array}{l}\text { Unlversidade Federal de Sergipe } \\
- \text { HU / UFS" }^{\text {U. }}\end{array}$ & Parecer Ilberado & 19/09/2012 & & \\
\hline $\begin{array}{l}\text { Hospttal Unwersttarlo de Aracajau } \\
\text { Unlversidade Federal de Sergipe/ } \\
\text { HU-UFS }\end{array}$ & Parecer Ilberado & 19/09/2012 & & \\
\hline $\begin{array}{l}\text { Hosphtal Unwersttarlo de Aracajal } \\
\text { Unlversidade Federal de Serglpe/ } \\
\text { HU-UFS }\end{array}$ & Notncą̧ăo enviada & 15/05/2014 & & 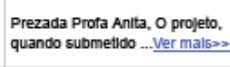 \\
\hline $\begin{array}{l}\text { Hospital Universttarlo de Aracajor } \\
\text { Universidade Federal de Sergipe/ } \\
\text { HU-UFS }\end{array}$ & Parecer Ilberado & 10/06/2014 & & \\
\hline
\end{tabular}

Locallzaçäo atual do Projeto: Pesqulkador Responsavel
Patrocinador Princlpal: CONS NAC DE DESENVOLVIMENTO CIENTIFICO E TECNOLOGICO

Localizoção atual do Projeto: Pesquisador Responsável

\begin{tabular}{|c|c|}
\hline Voltar & Envlar Notincaçao \\
\hline
\end{tabular} 


\section{HOSPITAL UNIVERSITÁRIO DE ARACAJÚ/ UNIVERSIDADE FEDERAL DE SERGIPE/ HU-}

\section{PARECER CONSUBSTANCIADO DO CEP}

\section{DADOS DO PROJETO DE PESQUISA}

Título da Pesquisa: Influência da Interação entre os Agentes Infecciosos e Hospedeiros na Patogênese de Doenças Infecciosas e Parasitárias

Pesquisador: Roque Pacheco de Almeida

Área Temática: Pesquisas com coordenação e/ou patrocínio originados fora do Brasil, excetuadas aquelas com copatrocínio do Governo Brasileiro;

Versão: 1

CAAE: 04587312.2 .0000 .0058

Instituição Proponente: FUNDACAO UNIVERSIDADE FEDERAL DE SERGIPE

Patrocinador Principal: CONS NAC DE DESENVOLVIMENTO CIENTIFICO E TECNOLOGICO

\section{DADOS DA NOTIFICAÇÃO}

Tipo de Notificação: Outros

Detalhe: Necessidade de envio ao CONEP

Justificativa: Prezada Profa Anita,

Data do Envio: 15/05/2014

Situação da Notificação: Parecer Consubstanciado Emitido

\section{DADOS DO PARECER}

Número do Parecer: 681.184

Data da Relatoria: 06/06/2014

Apresentação da Notificação:

Leishmanias isoladas de pacientes humanos e de cães serão armazenadas para caracterização da espécie e criação de um banco de Leishmania para posterior caracterização molecular (proteoma, microsatélites e RAPD)em colaboração com Elisa Cupolillo-FioCruz-RJ e correlacionar estes achados com o hospedeiro e evolução clínica e refratariedade ao tratamento. Estes dados serão importantes para um melhor entendimento da interação parasita hospedeiro e aplicabilidade clínica. Será necessário um número maior de isolados, que não

poderá ser realizado, somente, neste projeto. Todavia, este projeto será o marco inicial para futuros estudos para análise molecular dos isolados, além de estabelecer uma colaboração importante com a Fundação Oswaldo Cruz-RJ. Serão estocados também soros e urina para

Endereco: Rua Cláudio Batista $\mathrm{s} / \mathrm{n}^{\circ}$

Bairro: Sanatório

UF: SE Município: ARACAJU

Telefone: (79)2105-1805
CEP: $49.060-110$

E-mail: cephu@ufs.br 


\section{HOSPITAL UNIVERSITÁRIO DE ARACAJÚ/ UNIVERSIDADE FEDERAL DE SERGIPE/ HU-}

Continuaçăo do Parecer: 681.184

aplicação em futuros testes diagnósticos em colaboração com Dr Steve Reed e Ajay Bhatia do Infectious Diseases Research Institute (IDRI), Seatle,Washington, USA. A urina será utilizada para isolamento de antígenos de leishmania com finalidade de

desenvolver métodos diagnósticos de leishmaniose visceral utilizando a urina em vez do soro, que facilitará a metodologia diagnóstica desta importante doença. Os soros serão utilizados para avaliar a especificidade e sensibilidade de novos testes rápidos com antígenos recombinantes de leishmania produzidos no IDRI e dosage de citocinas e carga parasitária. Soros e urinas humanas serão enviadas para os Estados Unidos com essa finalidade.

\section{Objetivo da Notificação:}

Objetivo geral: Avaliação de fatores do parasito e do hospedeiro envolvidos na patogênese das Leishmanioses.

Objetivo específicos

1. Avaliar características fenotípicas e genotípicas do parasito de diferentes isolados de leishmanias e associar à patogênese da doença.

Avaliar a regulação de macrófagos caninos na infecção por diferentes isolados de L. chagasi através do índice de infecção e da produção de citocinas.

Avaliar a regulação de macrófagos humanos na infecção por diferentes isolados de L. chagasi através do índice de infecção e da produção de citocinas.

2. Investigar a susceptibilidade ao óxido nítrico em cepas de L. chagasi, isoladas de pacientes com LV.

3. Determinar a susceptibilidade ao antimonial em cepas de L. chagasi, isoladas de pacientes com LV.

4. Avaliar a atividade das enzimas cis-aconitase gliceraldeido-3-fosfato desidrogenase (GAPDH) e 6fosfogluconato desidrogenase (6PGDH)

Avaliar a expressão dos genes da cis-aconitase, GAPDH, 6PGDH e MRPA assim como determinar o número de cópias destes genes presentes no genoma dos isolados.

5. Identificar proteínas com padrão de expressão diferenciado entre os isolados resistentes e sensíveis ao NO

6. Avaliar o efeito do NO sobre aspectos morfofisiológicos e ultraestruturais de promastigotas de L.amazonensis e L. chagasi

7. Avaliar aspectos do hospedeiro associados à gravidade clínica e resposta terapêutica na LV.

8. Acompanhar a resposta imune da LV humana antes e após o tratamento, através da dosagem de citocinas e utilizá-la como marcador de evolução clínica.

Endereço: Rua Cláudio Batista $s / \mathrm{n}^{\circ}$

Bairro: Sanatório

UF: SE Município: ARACAJU

CEP: $49.060-110$

Telefone: (79)2105-1805

E-mail: cephu@ufs.br 


\section{HOSPITAL UNIVERSITÁRIO DE ARACAJÚ/ UNIVERSIDADE FEDERAL DE SERGIPE/ HU-

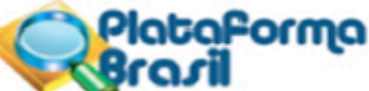

Continuaçẫo do Parecer: 681.184

9. Investigar o papel da heme-heme oxigenase na infecção por L. chagasi in vitro.

10. Determinar o papel das enzimas associadas ao sistema heme-heme-oxigenase e de mediadores inflamatórios sistêmicos como biomarcadores de prognóstico na LV humana.

11. Avaliar o papel da IL-17 e IL-22 na infecção por L. chagasi utilizando modelos experimentais

12. Investigar as alterações farmacocinéticas presentes na leishmaniose visceral humana.

13. Avaliar a resposta imune da LV canina, através da dosagem de citocinas e utilizá-las como marcadores de gravidade

14. Criar de bancos de Leishmania, soro e urina

\section{Avaliação dos Riscos e Benefícios:}

Não há riscos nem benefícios diretos aos participantes.

Comentários e Consideraçõos sobre a Notificação:

Não há entraves éticos.

Considerações sobre os Termos de apresentação obrigatória:

Constam do protocolo.

Recomendações:

Não há.

Conclusões ou Pendências e Lista de Inadequações:

Não há pendências.

Situação do Parecer:

Aprovado

Necessita Apreciação da CONEP:

Não

Considerações Finais a critério do CEP:

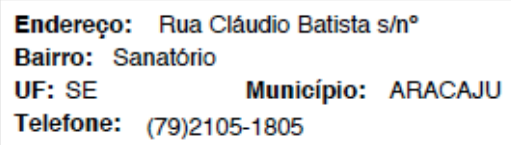

E-mail: cephu@ufs.br 


\section{Anexo 2 - Certificado de aprovação pelo Comitê de Ética em Experimentação} Animal

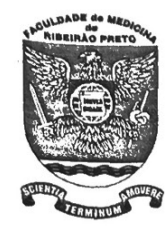

\section{UNIVERSIDADE DE SÃO PAULO \\ FACULDADE DE MEDICINA DE RIBEIRÃO PRETO \\ Comissão de Ética em Experimentação Animal}

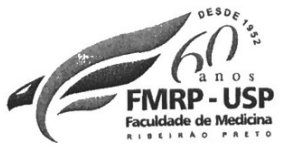

$3602-3301$

\section{CERTIFICADO}

Certificamos que o Protocolo para Uso de Animais em Experimentação $\mathbf{n}^{\circ}$ 076/2012, sobre o projeto intitulado "Caracterização dos mecanismos intracelulares dependentes da sinalização via NOD1/NOD2/RIP2 na geração e modulação da resposta imunológica adaptativa protetora durante a infecção por Leishmania infantum.", sob a responsabilidade do Professor Doutor João Santana da Silva está de acordo com os Princípios Éticos na Experimentação Animal adotado pelo Colégio Brasileiro de Experimentação Animal (COBEA) e foi APROVADO em reunião de 30 de julho de 2012.

(We certify that the protocol $n^{\circ} 076 / 2012$, about "Characterization of the mechanisms dependents of the intracellular signaling pathway NOD1/NOD2/RIP2 on the generation and modulation of the protective adaptive immune response during Leishmania infantum infection", agrees with the ETHICAL adaptive immune response auring IN ANIMAL RESEARCH adopted by Brazilian College of Animal Experimentation (COBEA) and was approved by the College of Medicine of Ribeirão Preto of the University of São Paulo - Ethical Commission of Ethics in Animal Research (CETEA) in 07/30/2012.

Ribeirão Preto, 30 de julho de 2012.

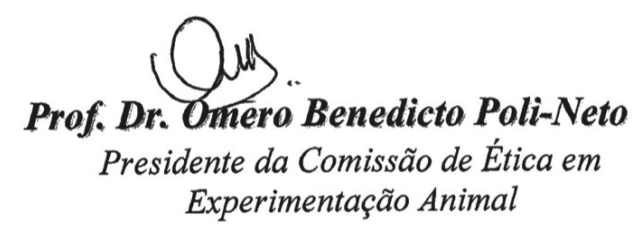




\section{Anexo 3 - Manuscrito da tese}

NOD2-RIP2-mediated signaling contributes to shape adaptive immunity in visceral leishmaniasis

Running tittle: NOD2-RIP2 modulates adaptive immunity in visceral leishmaniasis

Manuela S. L. Nascimento ${ }^{1}$, Marcela D. Ferreira ${ }^{1}$, Gustavo Quirino ${ }^{1}$, Jayendra K. Krishnaswamy ${ }^{2,3}$, Dong Liu ${ }^{2,3}$, Jonilson Berlink ${ }^{1}$, Denise M. da Fonseca ${ }^{1}$, Vanessa Carregaro $^{1}$ Roque P. Almeida ${ }^{4}$, Dario Zamboni ${ }^{1}$, Thiago M. Cunha ${ }^{1}$, Stephanie S. Eisenbarth $^{2,3}$, João S. Silva ${ }^{1^{*}}$.

${ }^{1}$ Department of Biochemistry and Immunology, Ribeirão Preto Medical School, University of São Paulo, Ribeirão Preto, SP, 14049-900, Brazil;

${ }^{2,3}$ Departments of ${ }^{2}$ Laboratory Medicine and ${ }^{3}$ Immunobiology, Yale University School of Medicine, New Haven, CT, 06520, USA;

${ }^{4}$ Center for Biology and Health Sciences, Federal University of Sergipe, Aracaju, SE, 49060-100, Brazil.

*Corresponding author: Phone: 55163602 3234. Email: jsdsilva@fmrp.usp.br

Word count of abstract: 147 
Footnote page

Conflict of interest: The authors have no conflicts of interest.

Funding: This work was supported by Núcleo de Apoio à Pesquisa em Doenças Inflamatórias [grant number: 11.1.21625.01.0] and Fundação de Amparo à Pesquisa do Estado de São Paulo [grant number: 2013/01967-2; 2014/10347-0 and 2012/14524-9].

Meetings: Presented in part in the Fifth World Congress on Leishmaniasis, Porto de Galinhas, PE, Brazil, on May 2013; Inflammatory Diseases: Recent Advances in Basic and Translational Research and Therapeutic Treatments. Emerging Cytokine Networks KEYSTONE SYMPOSIA, Vancouver, Canada on January 2014.

\#Corresponding author. João Santana da Silva. Mailing address: Ribeirão Preto Medical School - USP. Av. Bandeirantes, 3900 Ribeirão Preto, São Paulo 14049-900, Brazil. Phone: 55-16-3602-3234. E-mail: jsdsilva@fmrp.usp.br. 


\section{ABSTRACT}

IFN- $\gamma$ and IL-17A-producing cells are described to be related to the protection against Leishmania infantum infection. How the immune system coordinates the balance between Th1 and Th17 during visceral leishmaniasis (VL) is still unknown. We showed that Th17 is suppressed during $L$. infantum infection, and B cells are an important source for IL-17A. By using $\mathrm{Nod}^{-{ }^{-}}$and Rip2 $2^{--}$mice we characterized this pathway as a negative regulator for Th17 cells in VL. On the other hand, the high amount of Th1 induction in VL was dependent on the NOD2-RIP2 signaling in CD8 $\alpha^{+} X \mathrm{CR} 1^{+}$dendritic cells (DCs), which was crucial for IL12 production through the phosphorylation of p38 and JNK. As a consequence, $\mathrm{Nod}^{-{ }^{-}}$and Rip $2^{-/-}$mice showed a Th1 defective response and higher parasite loads compared to WT mice. Together, the data demonstrate that NOD2-RIP2 pathway plays a role in shaping adaptive immunity and promotes protection against VL.

Keywords: Leishmania infatum, NOD2, RIP2, dendritic cells, adaptive immunity. 


\section{INTRODUCTION}

Visceral leishmaniasis $(\mathrm{VL})$ is a chronic and potentially fatal parasitic disease caused by the intracellular Leishmania protozoan parasites. The disease affects populations from low and middle-income countries and leads to a significant health problems or death for up to 400,000 people per year around the world [1]. The effective immunity to VL is characterized by the development of a robust parasite-specific Th1/IFN- $\gamma$ response $[2,3]$ in detriment of IL10-producers patterns [4, 5]. The role of IL-17A-producing cells, however, is controversial, but, at long term, it seems to play a protective role against $V L$ through triggering the synthesis of leishmanicidal molecule by infected macrophages promoting parasite clearance [6-8]. The mechanism that coordinates the balance between Th1 and Th17 differentiation during $V L$ is still a lack of understanding.

Members from innate immunity have the ability to shape the adaptive immune response. As example, the activation of pattern recognition receptors (PRRs), as NOD-like receptors (NLRs), through either infectious agents or cellular stress [9], can initiate several signaling cascades resulting in the antigen presentation to naïve $T$ cells and then driving different aspects of cellular and humoral immunity $[10,11]$. In line with this matter, polymorphism in the gene of nucleotide-binding oligomerization domain containing 2 (NOD2) in patients with ocular toxoplasmosis was related to the production of IL-17A by CD4 ${ }^{+} \mathrm{T}$ lymphocytes [12]. The elegant ability of NOD2 as a Th17 regulator was described to be played through the induction of micro RNA (miR)-29 family in dendritic cells (DCs), impairing IL-12/23p40/IL-23 expression and, at last, inhibiting Th17 differentiation [13]. Other studies, however, defend that the activation of NOD2 in human DCs is responsible for the IL-23-IL-1IL-17 axis [14]. Besides Th17 modulation, NOD2 was reported as a critical mediator of Th2 polarization and potentiation [15, 16] and also as a Th1 inductor [17, 18] or inhibitior [19], depending on the model and synergism between other receptors. Besides the complexity of the pathway, NOD2 was first defined as a receptor for bacterial muramyl dipeptide (MDP) [20], but more agonist has been described, as N-glycolyl muramyl dipeptide [21] and singlestranded RNA [22], suggesting that this receptor can recognize a larger variety of structural elements. NOD2 signals via the adaptor molecule the serine/threonine Rip2 kinase [18] and is reported to be expressed particularly in antigen presenting cells (APC) [23]. Yet the role of NOD2-RIP2 signaling pathway during VL is unknown. 
DCs act as the most professional APC in that the cell machinery is geared towards antigen presentation and T cell activation [24]. Priming and maintenance of effectors T cells against Leishmania involve well-regulated actions of different DC subsets [25]. Basic leucin zipper transcription factor, ATF-like 3 (Batf3) -dependent CD $8 \alpha^{+} X \mathrm{CR} 1^{+} \mathrm{DCs}$ in addition to be specialized in cross presentation, is the major source of IL-12 in L. major infection, been crucial for Th1 immunity but dispensable for Th2 and Th17 [26, 27]. In the present study, we have focused on the mechanisms underlying the triggering of the NOD2-RIP2 pathway in modulating the protective immune response against $L$. infantum infection. Our data show that NOD2-RIP2 pathway in CD8 $\alpha^{+} X C R 1^{+} D C$ is critical for IL-12 production through MAPK components phosphorylation and then guarantee the development of Th1 lymphocytes, crucial for host resistance. On the other hand, this pathway inhibits Th17 differentiation because it limits IL-12/23p40/IL-23. In this context, B cells take place on the IL-17A production in VL by L. infantum.

\section{MATERIAL AND METHODS}

Mice

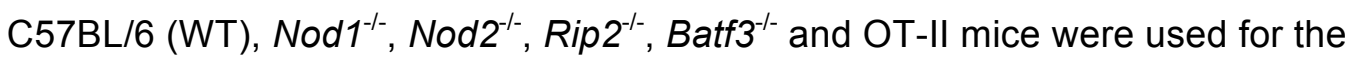
experiments. The animals were bred and maintained in a temperature-controlled rooms (22$25^{\circ} \mathrm{C}$ ) in our facility, receiving water and food ad libitum. All procedures were approved by the Ethics Committee in Animal Research of the Medical School of Ribeirão Preto-USP.

Parasites, experimental infection and parasite load determination

Isolate HU-UFS14 of Leishmania infantum was cultured in Schneider medium supplemented with $20 \%$ heat-inactivated foetal bovine serum, $5 \%$ penicillin and streptomycin (all from Sigma-Aldrich, MO, USA) and $2 \%$ human male urine. The mice were intravenously (iv) infected with $10^{7} \mathrm{~L}$. infantum parasites in the stationary growth phase, and hepatic and splenic parasite burdens were determined using a quantitative limiting dilution assay as preciously described $[28,29]$. 
Flow cytometry

Liver leukocytes were recovered using Percol (GE Healthcare, Buckinghamshire, United Kingdom) gradient centrifugation. For cytokine staining, the cells were pre-incubated with 50 $\mathrm{ng} / \mathrm{mL}$ of PMA, $500 \mathrm{ng} / \mathrm{mL}$ of ionomycin and Golgi Plug for $4 \mathrm{~h}$, fixed and permeabilized using a Cytofix/Cytoperm kit according to the manufacturer's instructions (BD Biosciences, CA, USA). The following antibodies were used for staining: CD19 (MB19-1), B220 (RA36B2), TCR $\beta$ (H57-597), CD4 (GK1.5), MHC II (M5/114.15.2), CD11C (N418), Ly6C (HK1.4), Ly6G (1A8), CD11b (M1/70), CD8 (53-6.7), IL-17A (TCII-18H10.1), IFN- $\gamma$ (XMG1.2) NK1.1 (PK136), TCR $\gamma \delta$ (GL3), CD86 (GL-1) e CD40 (3/23) (BioLegend, CA, USA or BD Bioscience). Single cell suspensions of spleen and liver were acquired either with FACSCanto II (BD Bioscience) or MACSQuant (Miltenyi Biotec, CA, USA) flow cytometer and analysed using FlowJo software (Tree Star, OR, USA).

\section{PCR array}

The purification of total RNA from tissues for PCR array analysis was performed with RNeasy Microarray Tissue Mini Kit (Qiagen, Hilden, Germany) including the optional oncolumn DNase digestion step, according the manufacturer's instructions. The cDNA synthesis was made from $0.5 \mu \mathrm{g}$ of total RNA, using $\mathrm{RT}^{2}$ First Strand Kit (Qiagen). $\mathrm{RT}^{2}$ Profiler PCR Arrays were performed in 96-well plates contain primer assays for 84 focused genes, 5 housekeeping genes, 3 wells contained reverse-transcription controls and 3 were for positive PCR controls. For this, the cDNA was mixed with $\mathrm{RT}^{2}$ SYBR Green Mastermix and aliquoted into the wells according the manufacturer's instructions. PCR was performed using a StepOnePlus ${ }^{\text {TM }}$ Real-Time PCR System (Applied Biosystems, Singapore) and the relative expression was determined using data from the real-time cycler and the $\Delta \Delta C T$ method in http://pcrdataanalysis.sabiosciences.com/pcr/arrayanalysis.php and http://bioinfo.genotoul.fr/index.php?id=116.

RNA extraction, cDNA synthesis and qPCR Real Time reaction

Total RNA was extracted from tissues and cells using the TRIzol reagent (Invitrogen, CA, USA) and the SV Total RNA Isolation System Kit (Promega, WI, USA) according to the manufacturer's instructions. cDNA was synthesised using Transcriptase Reverse SuperScript ${ }^{\mathrm{TM}}$ III (Invitrogen). SYBR Green Mix-based real-time quantitative PCR assays 
were performed using a StepOnePlus ${ }^{\mathrm{TM}}$ Real-Time PCR System (Applied Biosystems). The mean of the $\mathrm{Ct}$ values of duplicate measurements were used to calculate the expression of the target gene, which was normalized to the housekeeping gene hprt using the $2^{-\Delta \Delta \mathrm{Ct}}$ formula. The following primers were used for the reactions: Hprt, $\mathrm{F}$ TGGAAAAGCCAAATACAAAGC, R - CAACATCAACAGGACTCCTCG; I/6, F TTCCTACCCCAATTTCCAAT, R - CCTTCTGTGACTCCAGCTTATC; II23p19, F AATGTGCCCCGTATCCAGTGT, R - GGCTCCCCTTTGAAGATGTCA; $/ / 1 \beta$, F ATGGgCTGGACTGTTTCTAATG, R - ATTCACGAAAAGGGAGCTCC; I/17a, F TGCCCTCCACAATGAAAAGA, R - AACACGAAGCAGTTTGGGAC; Nod2, F CGACATCTCCCACAGAGTTGTAATCC, R - GGCACCTGAAGTTGACATTTTGC; Rip2, F TCATCGAGGTCTCATGATCTCTCT, R - AGCATTTCAAAAAGGATGGTCTTT; Tgf , F ACCGCAACAACGCCATCTAT, R - TCAAAAGACAGCCACTCAGGC; I/12/23p40, FGTTCGAATCCAGCGCAAGAA, R - GACATTCCCGCCTTTGCATT; I12p35, F CTGCTGAAATCTTCTCACCGT, R - AAGGGTGGCCAAAAAGAGGAG.

Bone marrow-derived dendritic cells (BM-DCs) differentiation and in vitro infection BM-DCs were cultured on non-tissue culture treated plates for 7 days in complete RPMI (Gibco/Thermo Fisher Scientific, MA, USA) supplemented with $20 \mathrm{ng} / \mathrm{mL}$ of recombinant GM-CSF (Peprotech, NJ, USA). The BM-DCs were gently flushed, transferred to tissue culture treated plates and infected with $L$. infantum (MOI 5 or 10), activated with $500 \mathrm{ng} / \mathrm{mL}$ LPS (Sigma-Aldrich) or transfected with $10 \mu \mathrm{g} / \mathrm{mL}$ MDP (InvivoGen, CA, USA).

\section{Confocal microscopy}

After $24 \mathrm{~h}$ of infection, BM-DCs were placed on top of the coverslips. The cells were fixed with $2 \%$ paraphormaldeyde and permeabilized with $0.5 \%$ Triton-X-100. Nonspecific sites were blocked with $1 \%$ BSA $+10 \%$ of rat serum (Cell Signaling Technologies, MA, USA). AntiNOD2 (H-300, Santa Cruz, Inc. TX, EUA) was incubated overnight and Alexa 488conjugated anti rabbit (Invitrogen, CA, EUA) was used as secondary antibody. The slides were mounted with Prolong contain DAPI (Cell Signalling Technologies), acquired using Leica SP5 and analyzed with Leica QWin Quantitative Imaging software (Leica Microsystems, Mannheim, Germany). The results are expressed as fluorescence intensity. 
In vitro culture and co-culture

Naïve T cells (CD4 $\left.{ }^{+} \mathrm{CD} 44^{-} \mathrm{CD} 62 \mathrm{~L}^{+}\right)$were isolated from WT lymph nodes by using FACSAria III sorting (BD Bioscience). The cells were cultured in $\alpha-C D 3$ and $\alpha-C D-28$ (BioXcell, NH, USA) precoated wells. Th1 was induced in the presence of $10 \mu \mathrm{g} / \mathrm{mL}$ of anti-IL-4 (BioXcell), $25 \mathrm{U} / \mathrm{mL}$ of $r \mathrm{LL}-2(\mathrm{BD})$ and $5 \mathrm{ng} / \mathrm{mL}$ of $r \mathrm{LL}-12$ (BioLegend). Th17 was induced by adding 10 $\mu \mathrm{g} / \mathrm{mL}$ of anti-IFN- $\gamma$ (BioXcell), $10 \mu \mathrm{g} / \mathrm{mL}$ of anti-IL-2 (BioXcell), $10 \mu \mathrm{g} / \mathrm{mL}$ of anti-IL-4, 20 $\mathrm{ng} / \mathrm{mL}$ of $r \mathrm{LL}-6$ (RD), $5 \mathrm{ng} / \mathrm{mL}$ of $r$ TGF- $\beta$ (Invitrogen), $20 \mathrm{ng} / \mathrm{mL}$ of $r \mathrm{lL}-1 \beta$ (R\&D Systems, MN, USA) and $50 \mathrm{ng} / \mathrm{mL}$ of $r \mathrm{lL}-23$ (RD Systems). The cells were cultured for 5-7 days under polarizing conditions and then analyzed by flow cytometry.

For the co-culture, BM-DCs were infected with 5 Leishmania/cell for $5 \mathrm{~h}$ and then pulsed with OVA for 45 min. Naïve OVA-specific OT-II cells were isolated by negative selection kit (Miltenyi Biotec) and co cultured with infected BM-DCs. At day 5 the cells were harvested and analyzed by flow cytometry.

\section{ELISA}

Soluble mediators were measured in the culture supernatants by enzyme-linked immunosorbent according to the manufacturer's instructions (R\&D Systems).

\section{Western blot}

Day 7 BM-DCs were stimulated as indicated and then collected for lysis using RIPA buffer (150 mM sodium chloride, $1.0 \%$ Nonidet P-40 or Triton X-100, $0.5 \%$ sodium deoxycholate, $0.1 \%$ SDS, and $50 \mathrm{mM}$ Tris, $\mathrm{pH}$ 8.0) containing 1X Phosphostop phosphatase and Complete protease inhibitors mixture (Roche, Basileia, Suíça). Total protein was quantified and the lysates were mixed with $5 \mathrm{X}$ Laemmli sample buffer (10\% SDS, 50\% Glycerol, 25\% betamercaptoethanol, 0,01\% Bromophenol blue in 1,5M Tris-HCl pH 6.8) for SDS/PAGE. Antibodies against phospho-JNK, total-JNK, phospho-p38, total-p38 and $\beta$-Actin (all from Cell signaling Technology) were used for protein detection after electrophoresis in $10 \%$ SDS-PAGE gel, tranference into nitrocelulose membrane (Merck Millipore, MA, USA) and blocking. Secondary YRP-conjugated antibodies were bought from KPL (MD, USA) and the westerns were developed using Luminata ${ }^{\mathrm{TM}}$ Western HRP Substrates (Merck Millipore). 
Immunofluorescence

Fresh spleen tissue was dehydrated through sequential solutions of sucrose $10 \%, 20 \%$ and $30 \%, 1$ hour each. The spleens were mounted in a cryomold with O.C.T. Compound (TissueTek, Sakura, Torrance, CA) and stored in the $-80^{\circ} \mathrm{C}$ freezer before to be cut and stain. 33D1 (33D1), XCR1 (ZET) and CD11C (N418) (BioLegend) were used for the three-colors fluorescence slides. Nikon eclipse Ti scope was used for acquisition using $4 x$ objectives. The results are expressed as the fluorescence intensity

\section{Statistical analysis}

Statistical significance was analysed using PRISM5 (GraphPad Software, CA, USA). The data are expressed as the mean \pm SD. Statistical differences were considered when $p<$ 0.05 .

\section{RESULTS}

$I L-17 A^{+}$cell population is mainly composed of $B$ cells

Recently, we demonstrated that $L$. infantum infection induces IL-17A production, which, together with IFN- $\gamma$, promotes the control of parasite replication inside the macrophages [6]. To assess which cell population was the source of IL-17A, we infected C57BL/6 mice with $L$. infantum and collected the spleen 4 weeks post infection (wpi) for analysis by flow cytometry. Surprisingly, low frequency of $C D 4^{+} T C R \beta^{+} I L-17 A^{+}$T cells was found (Figure $1 A$ ), whereas, as expected, they were a greater IFN- $\gamma$ producer (Figure $1 A$ ). Interestingly, CD19 ${ }^{+}$ $B$ cells produced remarkably amount of IL-17A, besides IFN- $\gamma$ (Figure 1B), being an important source of IL-17A induced by $L$. infantum infection (Figure $1 \mathrm{C}$ ). Other cells populations as $\mathrm{CD}^{+} \mathrm{T}$ cells, NK and $\gamma \delta \mathrm{T}$ cells were also analyzed, but neglected amount of IL-17A were coming from these cell types (Supplementary Figure 1). 
To understand why Th17 cells were inhibited by the infection, we generated and analyzed the transcriptional pattern of genes related with both innate and adaptive immune responses after $L$. infantum infection in C57BL/6 mice. For this, the liver was collected at $4^{\text {th }}$ and $6^{\text {th }}$ weeks post infection (wpi) and compared to non-infected controls by PCR array. A total of 84 genes were screened, been 56 up regulated at week $4^{\text {th }}, 52$ at week $6^{\text {th }}$ and 8 down regulated at both time points (Figures 1D, E and Supplementary Table 1). As expected, Ifng, Tbx21 and II17a were among the up regulated transcripts, being, respectively, $101.9591,28.5441$ and 3.6836 times at week $4^{\text {th }}$, and $53.7287,22.7839$ and 7.9639 times at week $6^{\text {th }}$ (Figure $\left.1 \mathrm{~F}\right)$. However, Rorc mRNA was down regulated at $4^{\text {th }}$ wpi and remained as the non-infected control at week $6^{\text {th }}$ (Figure $1 \mathrm{~F}$ and Supplementary Table 1).

Because the clear evidence demonstrating the down modulation of Th17 cells after Leishmania infection, we next asked how the parasite modulates the expression of Th17 inducers and/or inhibitors proteins. The PCR array data showed that the transcripts for the Th17-polaryzing cytokines $/ / 1 b$ and $/ / 6$ were positively regulated while $/ / 23 a$ was not induced at $4^{\text {th }}$ wpi (Figure 2A). Furthermore, Nod2, described as a limiting factor for IL-23 release [13], was induced by the infection (Figure 2A). We confirmed the Nod2 mRNA over expression by qPCR, which also showed a positive modulation for its adaptor molecule transcript, Rip2, in the liver of C57BL/6 mice (Figure 2B). Because we are studding the induction/repression of $\mathrm{T}$ cells responses and DCs are specialized cells in initiating adaptive immunity [24], we analyzed the Nod2 and Rip2 transcripts in these cells. We observed that the Leishmania was not only able to induce Nod2 and Rip2 mRNA expression in BM-DCs, but also amplified its expression in MDP-stimulated cells (Figure 2C). We also observed that, after BM-DC infection, the NOD2 is recruited and co-localizes with the parasite (Figure. 2D and Supplementary movie 1).

To test if NOD2-RIP2 pathway is responsible for the inhibition of Th17 in VL, we infected C57BL/6, Nod $2^{-/-}$and Rip2 $2^{-/-}$mice and analyzed the Th17 pattern at $4^{\text {th }}$ wpi. We

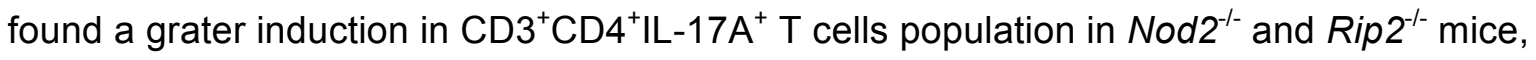
compared to WT in both spleen and liver (Figure 3A). Unexpectedly, even with more IL-17A

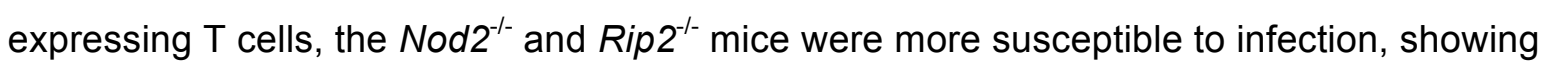
higher levels of parasite load in both spleen and liver compared to WT (Figure 3B). Besides, $\mathrm{Nod}^{-{ }^{--}}$and Rip2 $2^{-/-}$mice also developed an exacerbated hepatosplenomegaly (Figure $3 \mathrm{C}$ ). In order to understand this susceptibility pattern observed in $\mathrm{Nod}^{-{ }^{--}}$and $\mathrm{Rip}^{-{ }^{--}}$mice, we 
analyzed the Th1 profile, which are well know to be the most important cells to promote host resistance $[2,30]$. Nod $2^{--}$and $\operatorname{Rip} 2^{-/-}$mice showed a dramatically reduction in $\mathrm{CD} 3^{+} \mathrm{CD} 4^{+} \mathrm{IFN}-$ $\gamma^{+}$cells in both spleen and liver (Figure 3D). Altogether, the results demonstrate that the $L$. infantum infection induces NOD2 and RIP2 expression and that this pathway regulates the Th1 and Th17 differentiation, affecting the host resistance against $L$. infantum.

NOD2-RIP2 signaling pathway plays an extrinsic role in the modulation of Th1 and Th17 polarization.

We next asked whether the alterations on T cell differentiation observed in $\mathrm{Nod}^{-/}$ and Rip $^{-{ }^{-}}$mice was a consequence of the modulation orchestrated by the polarizing cell, as DCs, or by the polarized T cells. To address if there was any lymphocyte-dependent mechanism, we first sorted splenic $\mathrm{CD}^{+} \mathrm{CD} 4^{+} \mathrm{B} 220^{-} \mathrm{T}$ cells and $\mathrm{CD} 11 \mathrm{C}^{+} \mathrm{MHCII}^{+} \mathrm{CD} 3^{-} \mathrm{DCs}$ from naïve and infected C57BL/6 mice and analyzed the Nod2 and Rip2 mRNA expression in these cells population. As expected, the infection up regulated Nod2 and Rip2 transcripts on DCs but not in T cells (Figure 4A). Accordingly, $\mathrm{CD}^{+}{ }^{+} \mathrm{CD} 62 \mathrm{~L}^{+} \mathrm{CD} 44^{-}$naïve $\mathrm{T}$ cells from $\mathrm{Nod}^{2-{ }_{-}^{-}}$and Rip $^{- \text {- }^{-}}$mice were able to differentiate under polarizing conditions in vitro to Th1 or Th17 as good as a WT T lymphocytes (Figures 4B and C).

To confirm that the reduction in Th1 and the augment in Th17 observed in $\mathrm{Nod}^{-/}$and Rip $^{-/}$mice was due a T cell extrinsic mechanism, we co-cultured OVA-pulsed/ Leishmaniainfected BM-DCs from WT, Nod2 $2^{--}$and Rip2 $2^{-/}$mice with naive OT-II CD4 ${ }^{+}$T lymphocytes and checked for T cell differentiation. Interestingly, naïve lymphocytes co-cultured with $\mathrm{Nod}^{-/-}$ and Rip2 ${ }^{-/}$BM-DCs produced less IFN- $\gamma$ than those co-cultured with WT BM-DCs (Figure 4D). Also, the lymphocytes cultured with $\mathrm{Nod}^{-/-}$and Rip2 $2^{-/}$BM-DCs became better IL-17A producers when compared to the lymphocyte cultured with WT BM-DCs (Figure 4E).

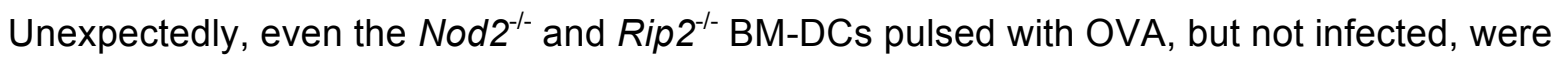
capable to induce better Th17 but less Th1 cells (data now shown), suggesting that apart of the antigen, $\mathrm{Nod}^{-/-}$and $\mathrm{Rip}^{-/-} \mathrm{DCs}$ already have a cellular machinery more prone to the production of Th17-polaryzing cytokines. Together, the data demonstrate that NOD2-RIP2 signaling pathway induces Th1 and inhibits Th17 cells through a DC intrinsic mechanism.

Having identified that the NOD2-RIP2 pathway in DCs, and not in T cells, are responsible for the modulation of Th1 and Th17 induction, we next examined the mechanism responsible for this event. We first analyzed if the components required for $\mathrm{T}$ cell activation and differentiation in DCs were altered in the absence of NOD2 and RIP2. We started 
determining the ability of DCs to differentiate from bone marrow precursors in vitro, since the co-culture was with BM-DCs and T cells. At day 7, no differences were found in the amount

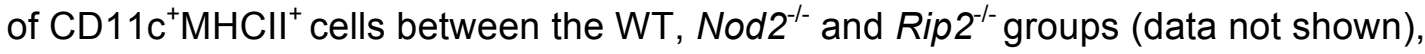
showing that even in the absence of NOD2 and RIP2, they can differentiate in DCs with the same efficacy as WT cells. Also, after infection with $L$. infantum or stimulation with LPS, the

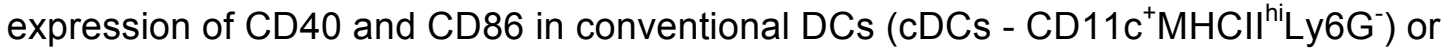
monocyte derived-DCs (moDCs - CD11 ${ }^{+} \mathrm{MHCII}^{\text {int }} \mathrm{Ly6G} \mathrm{G}^{-}$) are modulated as the same as in WT BM-DCs (Figure 5A). Regarding the soluble mediators required for lymphocyte polarization, we observed that after $L$. infantum infection, Nod2 $2^{-/}$and Rip2 ${ }^{-/}$BM-DCs were not able to express $/ 112 p 35$ mRNA as good as WT cells, but up-regulated I/12/23p40 transcripts (Figure 5B). Other molecules, as $/ 123 p 19, \| 1 \mathrm{~b}$, $/ / 6$, and Tgfb did not show statistically alterations (Figure 5B). The same result was observed in vivo, after $4^{\text {th }}$ weeks of infection (Figure $5 \mathrm{C}$ ). As a consequence of less $/ / 12$ p35 offer, reduced amount of IL-12p70 was detected in the supernatant of infected-Nod $2^{-/-}$and Rip2 ${ }^{-/}$BM-DCs, compared to WT (Figure 5D). The higher level of IL12/23p40 production in the absence of NOD2 and RIP2 than in WT was confirmed by ELISA (Figure 5E), which also showed that the increase of this compound associated with the down modulation of $1 / 12 p 35$ favors IL-23 release (Figure 5F). Together, these data indicate that NOD2-RIP2 signaling pathway modulates the cytokine production in the DC, creating a milieu that preferentially induces Th1 in detriment of Th17 cells.

NOD2-RIP2 signaling has been linked to cytokine production through the activation of MAPK pathway [31]. In fact, we found a remarkable defect in p38 and JNK phosphorylation in Nod2 $2^{-/-}$and Rip ${ }^{-/}$groups compared to WT (Figures $5 \mathrm{G}$ and $\mathrm{H}$ ), but no change in phosphoERK was observed (data not shown). The results show that in the absence of NOD2-RIP2 pathway the phosphorylation of p38 and JNK is impaired, which decreases IL-12 production, leading to a Th1 defective response. On the other hand, the high levels of II12/23p40 guarantee the offer of IL-23, ensuring the Th17 polarization in the absence of NOD2 and RIP2.

CD8 $\alpha^{+}$DCs are required for Th1 priming but not Th17 in VL

Different subtypes of DCs have been associated with preferentially promotion of certain types of T cells. Both $\mathrm{CD} 4^{+} 33 \mathrm{D} 1^{+}$and $\mathrm{CD} 8 \alpha^{+} X \mathrm{CR} 1^{+} \mathrm{DCs}$ are described to express 
Nod2 and Rip2 transcripts (http://www.immgen.org), but CD $8 \alpha^{+} \mathrm{XCR} 1^{+} \mathrm{DCs}$ are the major source of IL-12 during leishmaniasis, being a key population for Th1 development [26, 27]. To understand whether Nod2 $2^{-/-}$and Rip2 $2^{-/-}$have any defect in CD $8 \alpha^{+} X C R 1^{+}$DCs that could contribute for the down-modulation of Th1 observed in those mice, naïve spleens were collected for imaging the DCs subsets. The data show that CD4 ${ }^{+} 33 \mathrm{D} 1^{+}$and $\mathrm{CD} 8 \alpha^{+} \mathrm{XCR} 1^{+}$ DCs populations are present in the right amounts and location in the spleens of WT, Nod $2^{-/-}$ and $\operatorname{Rip} 2^{--}$(Figure $\left.6 \mathrm{~A}\right)$ and at $4^{\text {th }}$ wpi infection the both subsets are in equally amounts in all groups studied (Figure 6B). The data indicate that the difference in Th1 and Th17 amounts between WT and knockout mice is not due to a DC subsets issue.

We further investigated whether the polarization of Th1 and Th17 was restricted to specialized DCs subpopulations during VL. To address this question we first analyzed if these two DCs subsets presented different susceptibility to $L$. infantum infection. As shown in Figure 6C, the L. infantum infects better CD8 $\alpha^{+} X C R 1^{+} D C s$, but $C D 4^{+} 33 D 1^{+}$and double negative DCs are also well infected. To analyze the role of $C D 8 \alpha^{+} X C R 1^{+} \mathrm{DCs}$ in vivo, we infected Batf3 ${ }^{-/-}$mice, which lack CD $8 \alpha^{+} X C R 1^{+}$DCs development. Interestingly, at $4^{\text {th }}$ wpi, Batf3 $^{-/-}$mice showed a dramatically reduction in Th1 cells, and higher Th17 (Figure 6D), and the mice were more susceptible to $L$. infantum infection (Figure 6E). This data suggest that, as a main source of IL-12, CD $8 \alpha^{+} X \mathrm{CR} 1^{+}$are strictly important for a good prime of Th1 cells also in VL, but dispensable for Th17.

\section{DISCUSSION}

The modulation of PRRs signaling directly contributes to the onset of adaptive immunity. In this study we showed that the $L$. infantum infection triggers an innate immune stimulus through NOD2-RIP2 pathway in DCs, which contributes to p38 and JNK phosphorylation and leads to IL-12 production. On the other hand, this pathway controls IL-12/23p40 production and IL-23 release. As a consequence, a strong Th1 response is induced by CD $8 \alpha^{+} X C R 1^{+}$DCs, while Th17 is prevented. In face of Th17 inhibition, B cells are the relevant source of IL-17A after $L$. infantum infection. IL-17A has been reported to be produced by $B$ cells in rheumatoid arthritis patients [32], and also helps to combat parasites such as $T$. cruzi [33]. The $T$ cruzi activates IL-17A-producing B cell population via a unique pathway independent of the cytokines IL- 6 and IL-23 and the transcription factors ROR $\gamma$ t and 
AhR, but induces it directly by its trans-sialidase [33]. Our data show that Rorc is negatively modulated by $L$. infantum infection, indicating that the IL-17A detected after infection could be produced through a ROR $\gamma$ t independent pathway as well. L. donovani infection, however, has $\gamma \delta$ T cells as the major IL-17A source [34, 35], which was not relevant for L. infantum.

NOD2 has been implicated in the recognition of intracellular pathogens. We showed here that the infection by L. infantum induces both Nod2 and Rip2 transcripts in BM-DCs and also recruits NOD2, indicating that the infection is sensed by this receptor. Endo-lysosomes are the entry sites for intracellular pathogens, and therefore the sites at which the immune system needs to strengthen the surveillance. The endosomal Toll Like Receptors (TLR) as TLR3, TLR7, TLR 8 and TLR9 are all involved in the protection against Leishmania parasites [36-39]. There are evidences that endosomes are specialized platforms for NOD2 signaling, which also recruits RIP2 to the membrane, making an active signaling complex [40-42]. Another possibility is that the parasite could scape from the phagolysosomes and goes to the cytosol, where they can be sensed by citoplasmatic receptors [43].

The role of NOD2 and RIP2 in vivo was demonstrated by the increased susceptibility in $\mathrm{Nod}_{2}{ }^{-{ }_{-}}$and Rip2 ${ }^{-/-}$mice to $L$. infantum infection. The NOD pathway also protects the host against Chlamydophila pneumoniae [44], Staphylococcus aureus [45], T. cruzi [46], Listeria monocytogenes [9], Helicobacter pilori [47], T. gondii [48], Escherichia coli [49] and Pseudomonas aeruginosa [50]. NOD1, however, does not play any role in the model of $L$. infantum infection (data not shown). Besides more susceptible, Nod2--- and Rip2 ${ }^{-/-}$mice presented higher amount of Th17 in the spleen and liver after 4 weeks of infection. Indeed, the role of NOD2 in down regulate Th17 has been described [13]. In inflammatory bowel diseases, as Crohn's disease, or during ocular toxoplasmosis, the loss of function polymorphism of Nod2 gene is associated with the high levels of Th17 cells and the development of the symptoms [12, 51-53]. In addition to the increased amount of Th17 cells, $\mathrm{Nod}_{2}{ }^{-/}$and $\mathrm{Rip}^{-{ }^{-/}}$animals showed less Th1 response, which was clearly related to the susceptibility pattern in those animals. IL-17A is related to protection against $L$. infantum because it induces NO and increases the leishmanicidal ability of the macrophages [6]. However, as Th1 is classically associated with protection against all leishmaniasis and IFN- $\gamma$ does induce the production of much more anti-Leishmania molecules, so even with more Th17, Nod2 $2^{-/}$and Rip2 $2^{-/-}$mice are more susceptible because the defect in Th1 response. The role of NOD2 and RIP2 in induce Th1 has been demonstrated during toxoplasmosis and in the infection by L. monocytogenes $[9,48]$.

The modulation of the adaptive immune system by NOD2-RIP2 pathway is played by an 
extrinsic mechanism governed by dendritic cells. Our data showed that in the absence of NOD2 or RIP2 the phosphorylation of p38 and JNK is defective, which leads to an impairment of I/12p35 mRNA and IL-12p70 levels, explaining the low amount of Th1 in Nod2${ }^{\prime-}$ and Rip ${ }^{-/}$mice. Similar data was observed during the infection with L. monocytogenes [9], Mycobacterium avium [54], and also in human DCs stimulated with MDP and TLRs agonists [17]. Furthermore, a very elegant study showed that NOD2 senses the intensity of the TLR4 signaling, resulting in a synergic production of IL 12 when the TLR4 signal has low intensity, or inhibition of IL-12 secretion when this signaling is intensified [55]. On the other hand, the expression of IL-12/23p40 was increased in the knockout animals compared to WT, and, as the II23p19 mRNA levels was maintained, an augment of IL-23 production by infected Nod2${ }^{1-}$ and Rip ${ }^{-/}$BM-DCs was also observed, explaining the over induction of Th17 in Nod2-/and $\operatorname{Rip}^{-/}$animals compared to WT. In fact, it was previously demonstrated that miR-29 expression was upregulated in human dendritic cells (DCs) in response to NOD2 signals, and miR-29 downregulated the expression IL-23 by targeting IL-12p40 directly and IL-23p19 indirectly [13]. The modulation of IL-12 and IL-23 production covers complex events extensively studied because their roles in the polarization of Th1 and Th17, respectively, and, therefore, the impact in autoimmune and infectious diseases, for example.

Conventional DCs are the most important APC to induce response in naïve $T$ cells [56]. The two major $\mathrm{CDC}$ subsets in the spleen, $\mathrm{CD} 8 \mathrm{a \alpha}{ }^{+} \mathrm{XCR} 1^{+}$and $\mathrm{CD} 4^{+} 33 \mathrm{D} 1^{+}$express Nod2 and Rip2 transcripts, but are described to induce different T cell subsets. CD8aa ${ }^{+} X C R 1^{+}$ DCs are a greater IL-12 producer, playing an important role in Th1 induction $[57,58]$. And CD4 ${ }^{+} 33 \mathrm{D} 1^{+}$DCs are linked to Th17 differentiation [59-61]. The alterations in the amount of Th1 and Th17 lymphocytes observed in Nod2 ${ }^{-/-}$and Rip2 ${ }^{-/-}$mice were not related to different distribution of DCs populations in those animals. Nevertheless, in the Batf3/- mice, which lack the development of CD8aa+XCR1+ DCs, the animals showed a decrease in Th1 cells but augment of Th17. In addition, they were more susceptible to $L$. infantum infection, same phenotype observed in $\mathrm{Nod}^{-/-}$and Rip2 $2^{-/-}$mice. Together, these data suggest that the NOD2 and RIP2 expression in CD8aa+XCR1+ DCs might contributes to IL-12 production, influencing significantly the balance of adaptive immunity towards Th1 profile. Indeed, Batf $3^{-/-}$ mice are more susceptible to L. major infection, express less IL-12 and have defective Th1 response. These mice also presented more Th17, Th2 and Treg cells [26, 27].

In summary, we have presented here the critical role of NOD2 and RIP2 in a model that connects the mechanisms of parasite recognition trough innate system with the induction of adaptive immune responses. We showed that the NOD2-RIP2 signaling pathway plays an essential role in the parasite control, what was dependent on the modulation of cytokine 
production by the dendritic cell, which induce Th1, but inhibit the differentiation of Th17 lymphocytes. In this context, B cells contribute significantly as IL-17A producing cells during $V L$ caused by $L$. infantum. The identification of these events can open new perspectives for the development of immune interventions, rational strategies for treatment and prophylaxis for neglected chronic infectious diseases and potentially fatal, as visceral leishmaniasis.

\section{LEGENDS}

Figure 1: Th17 is impaired and Th1 is induced after Leishmania infantum infection.

C57BL/6 WT mice were iv infected with $10^{7}$ stationary growth phase of $L$. infantum. At week $4^{\text {th }}$ the animals were sacrificed and the spleen cells were stimulated with PMA and ionomicyn for $4 \mathrm{~h}(A, B$ and $C)$. IL-17 $\mathrm{A}^{+}$and IFN- $\gamma^{+}$populations were analyzed into the $\mathrm{CD} 4^{+} \mathrm{TCR} \beta^{+}$gate $(A)$ and in the $\mathrm{CD} 4{ }^{-} \mathrm{CD} 19^{+}$population $(B) . \mathrm{IL}-17 \mathrm{~A}^{+}$cells were analyzed according CD19 and CD4 expression (C). N = 3-4 mice, data representative of 4 independent experiments $(A, B$ and $C)$. The livers from infected WT and naïve controls were analysed by PCR array ( $D, E$ and $F)$. Scatter plots show the Log10 of normalized gene expression levels comparing data between non-infected animal ( $\mathrm{NI}, \mathrm{x}$-axis) versus the data from infected animal (4 wpi or 6 wpi, y-axis). The red symbols in the upper-left corner identify up-regulated genes, and the green symbols in the lower right corner are down-regulated genes. The black symbols represent unchanged gene expression (into the 1.75 threshold) $(D)$. The Venny diagram was made with the fold up- or down regulated values of the transcripts and shows co-regulated genes $(E)$. The graphs represent the fold change of Ifng (blue), Tbx21 (yellow), II17a (red) and Rorc (green) transcripts at $4^{\text {th }}$ and $6^{\text {th }}$ wpi; the grey area represents the threshold $(1.75)(F)$. The results are representative from 1 experiment, with a pool of 4 mice $(D, E$ and $F)$.

Figure 2: Leishmania infection induces Nod2 and Rip2 expression.

C57BL/6 WT mice were infected with $10^{7} \mathrm{~L}$. infantum in the stationary growth phase. At week $4^{\text {th }}$ post infection the livers from infected WT and naïve controls were analysed by PCR array. The graph represents the fold change of $I 11 \mathrm{~b},\|6\|$,23 and Nod2 transcripts; the grey area represents the threshold (1.75); the results are representative from 1 experiment, with a 
pool of 4 mice $(A)$. Nod2 and Rip2 mRNAs expression from the same sample from the PCR array were analysed by qPCR and normalized to the constitutive Hprt gene; dotted line represents naïve controls $(B)$. qPCR for Nod2 and Rip2 in WT BM-DCs after 6 hours of infection with L. infantum (5 parasites: 1 cell), stimulated with MDP $(10 \mu \mathrm{g} / \mathrm{mL})$ or both $(C)$. The NOD2 localization after $24 \mathrm{~h}$ of Leishmania-labeled CFSE infection (MOI 5) in BM-DCs was analysed by confocal microscopy and is shown as fluorescence intensity. The cellular nucleus was stain with DAPI and is shown in blue, the parasite is green and the NOD2 is red $(D) . \mathrm{N}=3-5$ mice/group. Data are representative of 3 independent experiments.

Figure 3: NOD2-RIP2 signaling balances the immune response toward Th1 instead of Th17 profile.

WT, Nod2 $2^{-/}$and Rip $2^{-/-}$mice were infected with $10^{7} \mathrm{~L}$. infantum in the stationary growth phase. The spleens and livers were harvested at $4^{\text {th }}$ wpi and the single cell suspension was stimulated with PMA and ionomicyn for $4 \mathrm{~h}(A$ and $D)$. CD4 ${ }^{+} \mathrm{IL}-17 \mathrm{~A}^{+}$cells analysis was performed by flow cytometry into $C D 3^{+} B 220^{-}$population $(A)$. Parasite loads were determined by limiting dilution assay and are expressed as the mean values \pm SD $(B)$. Spleens and livers from $B$ were weighted and pictured $(C)$. The dot plots showing the $\mathrm{CD} 4^{+} \mathrm{IFN}-\gamma^{+}$cells was assessed by flow cytometry into $C D 3^{+} B 220^{-}$population $(D) . \mathrm{N}=4-5$ mice/group. The results are representative of 3 independent experiments. ${ }^{*} P<0.05$, compared to WT control.

Figure 4: NOD2-RIP2 signaling plays an extrinsic role in Th1 and Th17 polarization.

WT T cells $\left(\mathrm{CD}^{+}{ }^{\mathrm{CD}} 4^{+} \mathrm{B}^{2} 20^{-}\right)$and $\mathrm{DCs}\left(\mathrm{CD} 11 \mathrm{C}^{+} \mathrm{MHCll}^{+} \mathrm{CD} 3^{-}\right)$were sorted from the spleen of infected $\left(4^{\text {th }}\right.$ and $6^{\text {th }}$ wpi) and naïve mice. Nod2 and Rip2 transcripts were measured by qPCR and normalized to the constitutive Hprt. Dotted lines represent naïve controls $(A)$. Naïve T cells (CD4 $\left.{ }^{+} \mathrm{CD} 62 \mathrm{~L}^{+} \mathrm{CD} 44^{-}\right)$were isolated by sorting from the lymph nodes. The cells were cultured for 7 days in a Th1 $(B)$ or Th17 $(C)$ polarizing conditions. BM-DCs from WT, $\mathrm{Nod}^{-/-}$and Rip $^{-{ }^{--}}$mice were infected with 5 parasites/cell for $5 \mathrm{~h}$ and then pulsed with OVA $(100 \mu \mathrm{g} / \mathrm{mL})$ for $45 \mathrm{~min}$. OT-II cells were co-cultured with BM-DCs for 5 days and then harvested for the assessment of Th1 $(D)$ and Th17 $(E)$ differentiation by flow cytometry. $\mathrm{N}=$ 4 /group. The results are representative of 2-3 independent experiments. 
Figure 5: NOD2-RIP2 induces Th1-polarizing cytokine, but inhibit Th17-polarizing cytokine.

BM-DCs from WT, Nod2 $2^{-/}$and Rip ${ }^{-/-}$mice were infected with 10 parasites/cell (blue), stimulated with LPS (500 ng/mL) (orange) or remained unstimulated (red) overnight. CD40 and CD86 expression were analysed by flow cytometry in conventional DCs (cDCs CD11 ${ }^{+} \mathrm{MHCII}^{\mathrm{hi}}$ Ly6G $^{-}$) and monocyte-derived DCs (moDCs - CD11 ${ }^{+} \mathrm{MHCII}^{\text {int }}$ Ly6G ${ }^{-}$) populations $(A)$. BM-DCs from indicated groups were infected for 6 hours and the expression of $/ 112 p 35,\|12 / 23 p 40\| 23 p 19,, \| 1 b$, $/ / 6$ and Tgfb mRNAs was determined by qPCR $(B)$. At week $4^{\text {th }}$ after infection, the livers from WT, Nod $2^{-/-}$and Rip $2^{-/-}$mice were harvested for $\mathrm{qPCR}$ analysis $(C)$. Dotted lines represent naïve controls, the housekeeping Hprt was used for normalizations ( $B$ and $C$ ). IL-12p70 (D), IL-12/23p40 (E) and IL-23 (F) production were measured in the supernatant of infected BM-DCs (black bars) and naïve controls (white bars) by ELISA after 24h of infection. Western blot analysis of phospho P38 (G), phospho JNK $(H)$ and their respective total proteins were measured in the total cell lysates from of a naïve and infected (30 min) BM-DCs. N = 2-4 /group. nd, non-detected Representative of 3 independent experiments. ${ }^{*}, \mathrm{P}<0,05$.

Figure 6: $\mathrm{CD} 8 \alpha^{+} \mathrm{XCR} 1^{+} \mathrm{DCs}$ are required for a robust Th1 response but not for Th17 induction.

Fluorescent images from WT, Nod2 $2^{-/-}$and Rip2 $2^{-/-}$naïve mice are shown in the $4 \mathrm{X}$ objective. The following stain are shown: 33D1 or XCR1 (red); CD169/MOMA (green); CD11c (blue).

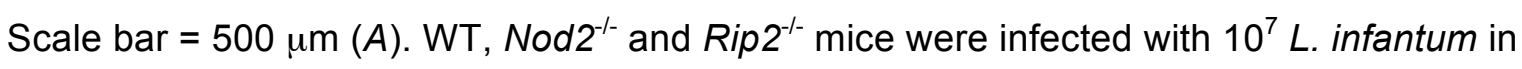
the stationary growth phase. At $4^{\text {th }}$ wpi the spleens were harvested and the DCs subsets were analysed by flow cytometry, the population shown was gated in $\mathrm{CD} 11 \mathrm{C}^{+} \mathrm{MHCI}{ }^{+} \mathrm{TCR} \beta^{-}$ $(B)$. Enriched splenic DCs were infected with CFSE-labeled parasites (10:1) for $2 \mathrm{~h}$ and then stained for flow cytometry analysis $(C)$. WT and Batf3-- animals were infected with $10^{7} \mathrm{~L}$. infantum in the stationary growth phase. At $4^{\text {th }}$ wpi the spleens were harvested and the single cell suspension was stimulated with PMA and ionomicyn for $4 \mathrm{~h}$. CD $4^{+} \mathrm{IFN}-\gamma^{+}$and CD $4^{+} \mathrm{IL}-17 \mathrm{~A}^{+}$cells were gated in TCR $\beta^{+}$population (D). Parasite load was determined by limiting dilution assay in the liver and is expressed as the mean values $\pm S D(E)$. $N=2-3$ mice/group. Data are representative of 3 independent experiments. 
Figure 7: NOD2-RIP2 signaling contributes to shape adaptive immunity interfering in the outcome of $L$. infantum infection.

CD8 $\alpha^{+} X C R 1^{+} \mathrm{DCs}$ and $33 \mathrm{D} 1^{+} \mathrm{CD} 4^{+} \mathrm{DC}$ s express NOD2 and RIP2 and are susceptible to $L$. infantum infection. Once infected, NOD2 is recruited, co-localizes with the parasite, senses the infection and signals through RIP2 to induce high amounts of IL-12 via p38 and JNK phosphorilation. This same pathway inhibits II12/23p40, limiting IL-23 release. In this microenvironment the adaptive immunity is balanced toward Th1 polarization. Upon Th17 inhibition, B cells guarantee the IL-17A production during VL by Leishmania infantum. The mechanisms of IL-17A-producing $B$ cells induction remain unknown.

\section{SUPLEMENTARY INFORMATION}

Supplementary Figure 1: CD8 ${ }^{+} \mathrm{T}$ cells, NK and $\gamma \delta \mathrm{T}$ cells are not a great IL-17A producer after $L$. infantum infection.

C57BL/6 WT mice were iv infected with $10^{7}$ stationary growth phase of $L$. infantum. At week $4^{\text {th }}$ the animals were sacrificed and the spleen cells were stimulated with PMA and ionomicyn for $4 \mathrm{~h}$ IL-17A expression was assessed in $\mathrm{CD}^{+}, \mathrm{NK} 1.1^{+}$and $\mathrm{TCR} \gamma \delta^{+}$populations.

Supplementary Table 1: Gene expression alterations at $4^{\text {th }}$ and $6^{\text {th }}$ wpi in the liver of C57BL/6 mice.

Supplementary Movie 1: NOD2 is recruited and co-localizes with the parasite.

The NOD2 localization after $24 \mathrm{~h}$ of Leishmania-labeled CFSE infection (MOI 5) in BM-DCs was analysed by confocal microscopy. The cellular nucleus was stain with DAPI and is shown in blue, the parasite is green and the NOD2 is red. 


\section{REFERENCES}

1. Ready PD. Epidemiology of visceral leishmaniasis. Clinical epidemiology 2014; 6:147-54.

2. Ghalib HW, Whittle JA, Kubin M, et al. IL-12 enhances Th1-type responses in human Leishmania donovani infections. J Immunol 1995; 154:4623-9.

3. Squires KE, Schreiber RD, McElrath MJ, Rubin BY, Anderson SL, Murray HW.

Experimental visceral leishmaniasis: role of endogenous IFN-gamma in host defense and tissue granulomatous response. J Immunol 1989; 143:4244-9.

4. Ghalib HW, Piuvezam MR, Skeiky YA, et al. Interleukin 10 production correlates with pathology in human Leishmania donovani infections. The Journal of clinical investigation 1993; 92:324-9.

5. Gautam S, Kumar R, Maurya R, et al. IL-10 neutralization promotes parasite clearance in splenic aspirate cells from patients with visceral leishmaniasis. The Journal of infectious diseases 2011; 204:1134-7.

6. Nascimento MS, Carregaro V, Lima-Junior DS, et al. Interleukin 17A acts synergistically with interferon gamma to promote protection against Leishmania infantum infection. The Journal of infectious diseases 2015; 211:1015-26.

7. Ghosh K, Sharma G, Saha A, Kar S, Das PK, Ukil A. Successful therapy of visceral leishmaniasis with curdlan involves T-helper 17 cytokines. The Journal of infectious diseases 2013; 207:1016-25.

8. Sheel M, Beattie L, Frame TC, et al. IL-17A-Producing gammadelta T Cells Suppress Early Control of Parasite Growth by Monocytes in the Liver. J Immunol 2015.

9. Chin AI, Dempsey PW, Bruhn K, Miller JF, Xu Y, Cheng G. Involvement of receptorinteracting protein 2 in innate and adaptive immune responses. Nature 2002; 416:190-4.

10. Liu D, Rhebergen AM, Eisenbarth SC. Licensing Adaptive Immunity by NOD-Like Receptors. Frontiers in immunology 2013; 4:486.

11. Takeuchi O, Akira S. Pattern recognition receptors and inflammation. Cell 2010; 140:80520.

12. Dutra MS, Bela SR, Peixoto-Rangel AL, et al. Association of a NOD2 gene polymorphism and T-helper 17 cells with presumed ocular toxoplasmosis. The Journal of infectious diseases 2013; 207:152-63.

13. Brain O, Owens BM, Pichulik T, et al. The intracellular sensor NOD2 induces microRNA29 expression in human dendritic cells to limit IL-23 release. Immunity 2013; 39:521-36.

14. van Beelen AJ, Teunissen MB, Kapsenberg ML, de Jong EC. Interleukin-17 in inflammatory skin disorders. Current opinion in allergy and clinical immunology 2007; 7:374-81.

15. Magalhaes JG, Fritz JH, Le Bourhis L, et al. Nod2-dependent Th2 polarization of antigenspecific immunity. J Immunol 2008; 181:7925-35. 
16. Magalhaes JG, Rubino SJ, Travassos LH, et al. Nucleotide oligomerization domaincontaining proteins instruct $\mathrm{T}$ cell helper type 2 immunity through stromal activation. Proceedings of the National Academy of Sciences of the United States of America 2011; 108:14896-901.

17. Tada H, Aiba S, Shibata K, Ohteki T, Takada H. Synergistic effect of Nod1 and Nod2 agonists with toll-like receptor agonists on human dendritic cells to generate interleukin-12 and T helper type 1 cells. Infection and immunity 2005; 73:7967-76.

18. Kobayashi K, Inohara N, Hernandez LD, et al. RICK/Rip2/CARDIAK mediates signalling for receptors of the innate and adaptive immune systems. Nature 2002; 416:194-9.

19. Watanabe T, Kitani A, Murray PJ, Strober W. NOD2 is a negative regulator of Toll-like receptor 2-mediated $\mathrm{T}$ helper type 1 responses. Nature immunology 2004; 5:800-8.

20. Girardin SE, Boneca IG, Viala $\mathrm{J}$, et al. Nod2 is a general sensor of peptidoglycan through muramyl dipeptide (MDP) detection. The Journal of biological chemistry 2003; 278:8869-72.

21. Coulombe F, Divangahi M, Veyrier F, et al. Increased NOD2-mediated recognition of Nglycolyl muramyl dipeptide. The Journal of experimental medicine 2009; 206:1709-16.

22. Sabbah A, Chang TH, Harnack R, et al. Activation of innate immune antiviral responses by Nod2. Nature immunology 2009; 10:1073-80.

23. Elia PP, Tolentino YF, Bernardazzi C, de Souza HS. The role of innate immunity receptors in the pathogenesis of inflammatory bowel disease. Mediators of inflammation 2015; 2015:936193.

24. Rossi M, Young JW. Human dendritic cells: potent antigen-presenting cells at the crossroads of innate and adaptive immunity. J Immunol 2005; 175:1373-81.

25. Kautz-Neu K, Schwonberg K, Fischer MR, Schermann AI, von Stebut E. Dendritic cells in Leishmania major infections: mechanisms of parasite uptake, cell activation and evidence for physiological relevance. Medical microbiology and immunology 2012; 201:581-92.

26. Martinez-Lopez M, Iborra S, Conde-Garrosa R, Sancho D. Batf3-dependent CD103+ dendritic cells are major producers of IL-12 that drive local Th1 immunity against Leishmania major infection in mice. European journal of immunology 2015; 45:119-29.

27. Ashok D, Schuster S, Ronet C, et al. Cross-presenting dendritic cells are required for control of Leishmania major infection. European journal of immunology 2014; 44:1422-32.

28. Buffet PA, Sulahian A, Garin YJ, Nassar N, Derouin F. Culture microtitration: a sensitive method for quantifying Leishmania infantum in tissues of infected mice. Antimicrobial agents and chemotherapy 1995; 39:2167-8.

29. Titus RG, Marchand M, Boon T, Louis JA. A limiting dilution assay for quantifying Leishmania major in tissues of infected mice. Parasite immunology 1985; 7:545-55.

30. Carvalho EM, Badaro R, Reed SG, Jones TC, Johnson WD, Jr. Absence of gamma interferon and interleukin 2 production during active visceral leishmaniasis. The Journal of clinical investigation 1985; 76:2066-9. 
31. Chen G, Shaw MH, Kim YG, Nunez G. NOD-like receptors: role in innate immunity and inflammatory disease. Annual review of pathology 2009; 4:365-98.

32. Schlegel PM, Steiert I, Kotter I, Muller CA. B cells contribute to heterogeneity of IL-17 producing cells in rheumatoid arthritis and healthy controls. PloS one 2013; 8:e82580.

33. Bermejo DA, Jackson SW, Gorosito-Serran M, et al. Trypanosoma cruzi trans-sialidase initiates a program independent of the transcription factors RORgammat and Ahr that leads to IL-17 production by activated B cells. Nature immunology 2013; 14:514-22.

34. Sheel M, Beattie L, Frame TC, et al. IL-17A-Producing gammadelta T Cells Suppress Early Control of Parasite Growth by Monocytes in the Liver. J Immunol 2015; 195:5707-17.

35. Terrazas C, Varikuti S, Kimble J, Moretti E, Boyaka PN, Satoskar AR. IL-17A promotes susceptibility during experimental visceral leishmaniasis caused by Leishmania donovani. FASEB journal : official publication of the Federation of American Societies for Experimental Biology 2015.

36. Flandin JF, Chano F, Descoteaux A. RNA interference reveals a role for TLR2 and TLR3 in the recognition of Leishmania donovani promastigotes by interferon-gamma-primed macrophages. European journal of immunology 2006; 36:411-20.

37. Paun A, Bankoti R, Joshi T, Pitha PM, Stager S. Critical role of IRF-5 in the development of $\mathrm{T}$ helper 1 responses to Leishmania donovani infection. PLoS pathogens 2011; 7:e1001246.

38. Zhang WW, Matlashewski G. Immunization with a Toll-like receptor 7 and/or 8 agonist vaccine adjuvant increases protective immunity against Leishmania major in BALB/c mice. Infection and immunity 2008; 76:3777-83.

39. Sacramento L, Trevelin SC, Nascimento MS, et al. Toll-Like Receptor 9 Signaling in Dendritic Cells Regulates Neutrophil Recruitment to Inflammatory Foci following Leishmania infantum Infection. Infection and immunity 2015; 83:4604-16.

40. Herskovits AA, Auerbuch V, Portnoy DA. Bacterial ligands generated in a phagosome are targets of the cytosolic innate immune system. PLoS pathogens 2007; 3:e51.

41. Lecine P, Esmiol S, Metais JY, et al. The NOD2-RICK complex signals from the plasma membrane. The Journal of biological chemistry 2007; 282:15197-207.

42. Nakamura N, Lill JR, Phung Q, et al. Endosomes are specialized platforms for bacterial sensing and NOD2 signalling. Nature 2014; 509:240-4.

43. Lima-Junior DS, Costa DL, Carregaro V, et al. Inflammasome-derived IL-1beta production induces nitric oxide-mediated resistance to Leishmania. Nature medicine 2013; 19:909-15.

44. Shimada K, Chen S, Dempsey PW, et al. The NOD/RIP2 pathway is essential for host defenses against Chlamydophila pneumoniae lung infection. PLoS pathogens 2009; 5:e1000379.

45. McCully ML, Fairhead T, Colmont CS, et al. Receptor-interacting protein-2 deficiency delays macrophage migration and increases intracellular infection during peritoneal dialysisassociated peritonitis. American journal of nephrology 2008; 28:879-89. 
46. Silva GK, Gutierrez FR, Guedes PM, et al. Cutting edge: nucleotide-binding oligomerization domain 1-dependent responses account for murine resistance against Trypanosoma cruzi infection. J Immunol 2010; 184:1148-52.

47. Fritz JH, Le Bourhis L, Sellge G, et al. Nod1-mediated innate immune recognition of peptidoglycan contributes to the onset of adaptive immunity. Immunity 2007; 26:445-59.

48. Shaw MH, Reimer T, Sanchez-Valdepenas C, et al. T cell-intrinsic role of Nod 2 in promoting type 1 immunity to Toxoplasma gondii. Nature immunology 2009; 10:1267-74.

49. Kim JG, Lee SJ, Kagnoff MF. Nod1 is an essential signal transducer in intestinal epithelial cells infected with bacteria that avoid recognition by toll-like receptors. Infection and immunity 2004; 72:1487-95.

50. Travassos LH, Carneiro LA, Girardin SE, et al. Nod1 participates in the innate immune response to Pseudomonas aeruginosa. The Journal of biological chemistry 2005; 280:36714-8.

51. Economou M, Trikalinos TA, Loizou KT, Tsianos EV, Ioannidis JP. Differential effects of NOD2 variants on Crohn's disease risk and phenotype in diverse populations: a metaanalysis. The American journal of gastroenterology 2004; 99:2393-404.

52. Bonen DK, Ogura Y, Nicolae DL, et al. Crohn's disease-associated NOD2 variants share a signaling defect in response to lipopolysaccharide and peptidoglycan. Gastroenterology 2003; 124:140-6.

53. Franke A, McGovern DP, Barrett JC, et al. Genome-wide meta-analysis increases to 71 the number of confirmed Crohn's disease susceptibility loci. Nature genetics 2010; 42:1118-25.

54. Carvalho NB, Oliveira FS, Marinho FA, et al. Nucleotide-binding oligomerization domain-2 (NOD2) regulates type-1 cytokine responses to Mycobacterium avium but is not required for host control of infection. Microbes and infection / Institut Pasteur 2015; 17:337-44.

55. Kim H, Zhao Q, Zheng H, Li X, Zhang T, Ma X. A novel crosstalk between TLR4- and NOD2-mediated signaling in the regulation of intestinal inflammation. Scientific reports 2015; $5: 12018$.

56. Meredith MM, Liu K, Darrasse-Jeze G, et al. Expression of the zinc finger transcription factor zDC (Zbtb46, Btbd4) defines the classical dendritic cell lineage. The Journal of experimental medicine 2012; 209:1153-65.

57. Rissoan MC, Soumelis V, Kadowaki N, et al. Reciprocal control of T helper cell and dendritic cell differentiation. Science 1999; 283:1183-6.

58. Maldonado-Lopez R, Maliszewski C, Urbain J, Moser M. Cytokines regulate the capacity of CD8alpha(+) and CD8alpha(-) dendritic cells to prime Th1/Th2 cells in vivo. J Immunol 2001; 167:4345-50.

59. Persson EK, Uronen-Hansson H, Semmrich M, et al. IRF4 transcription-factor-dependent $\mathrm{CD} 103(+) \mathrm{CD} 11 \mathrm{~b}(+)$ dendritic cells drive mucosal $\mathrm{T}$ helper 17 cell differentiation. Immunity 2013; 38:958-69. 
60. Schlitzer A, McGovern N, Teo P, et al. IRF4 transcription factor-dependent CD11b+ dendritic cells in human and mouse control mucosal IL-17 cytokine responses. Immunity 2013; 38:970-83.

61. Wenzel UA, Jonstrand C, Hansson GC, Wick MJ. CD103+ CD11b+ Dendritic Cells Induce Th17 T Cells in Muc2-Deficient Mice with Extensively Spread Colitis. PloS one 2015; 10:e130750. 
Figure 1

A

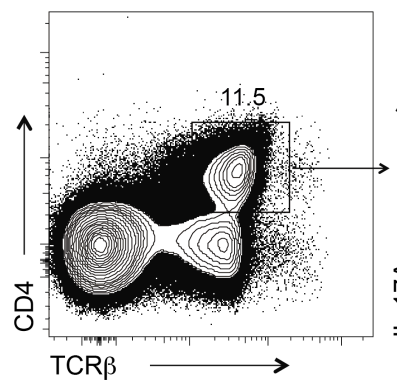

C

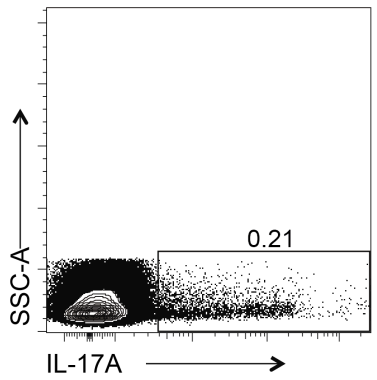

E

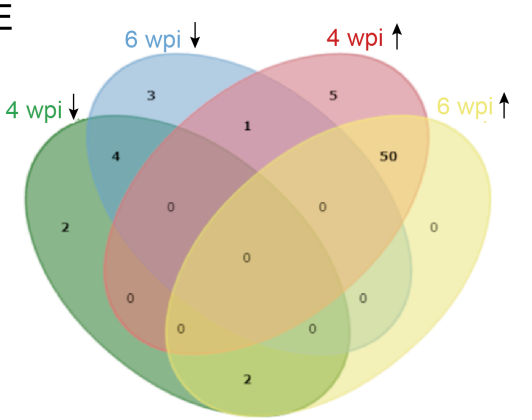

B
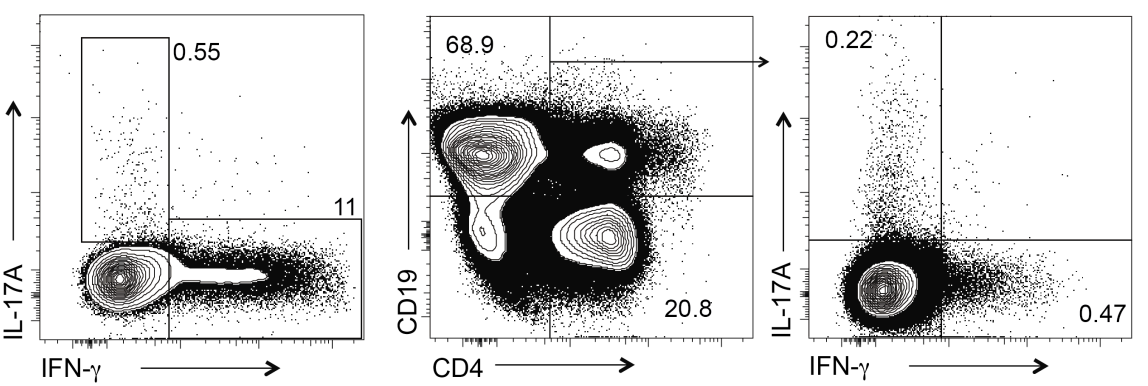

D
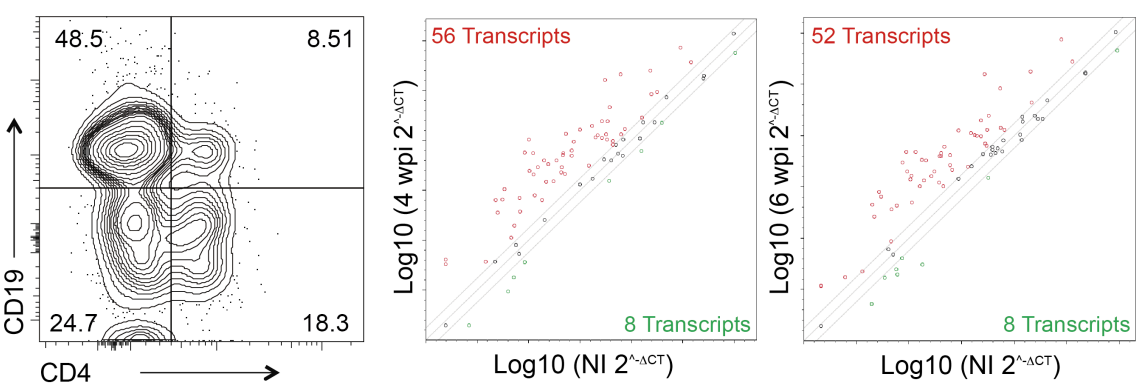

F
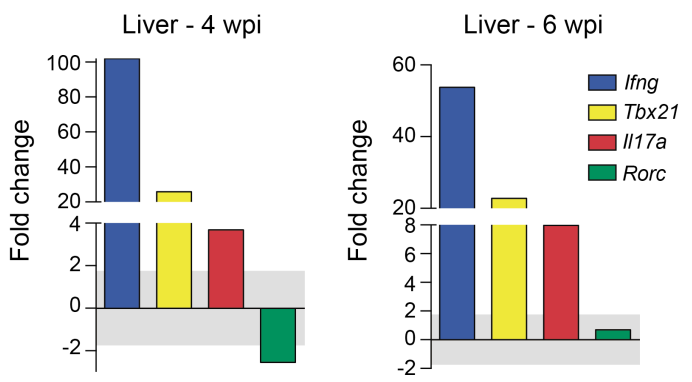
Figure 2

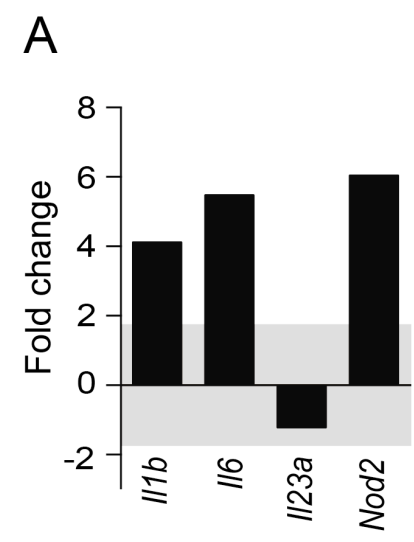

B

C
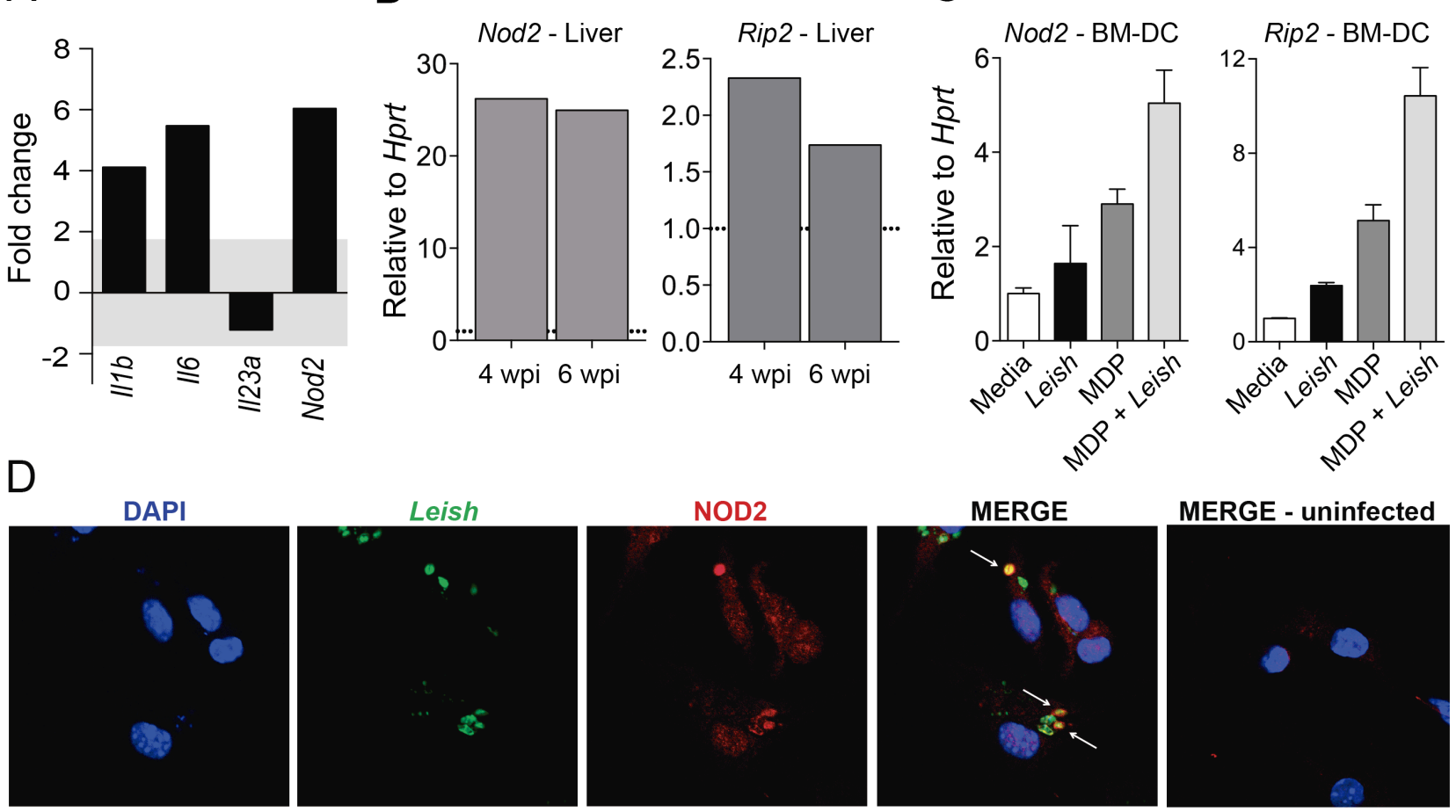

Leish

NOD2

MERGE

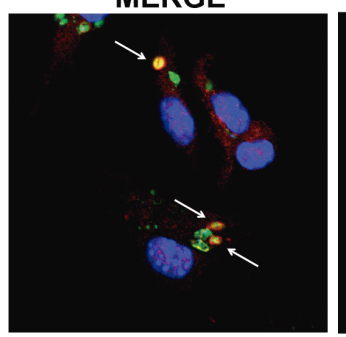

MERGE - uninfected

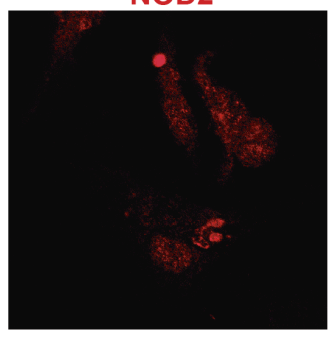

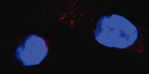


Figure 3

A
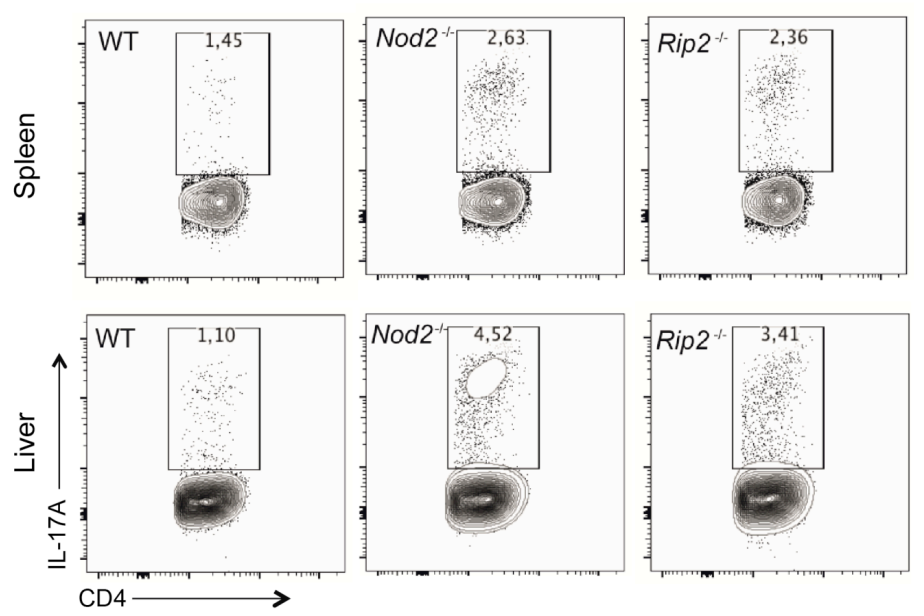

C

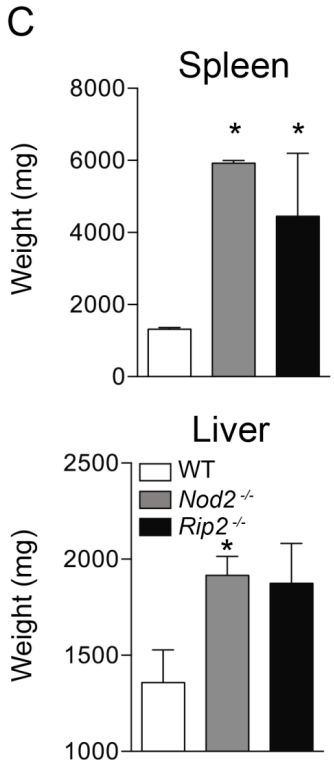

\section{B}
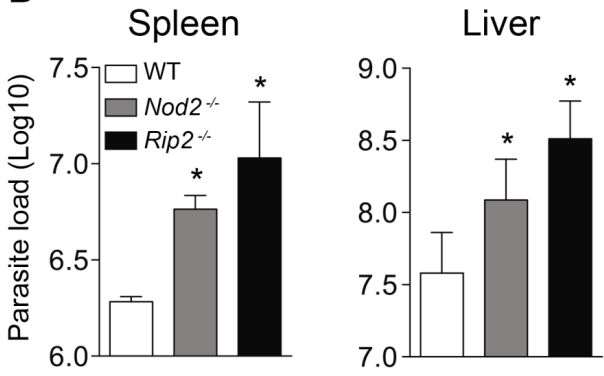

D
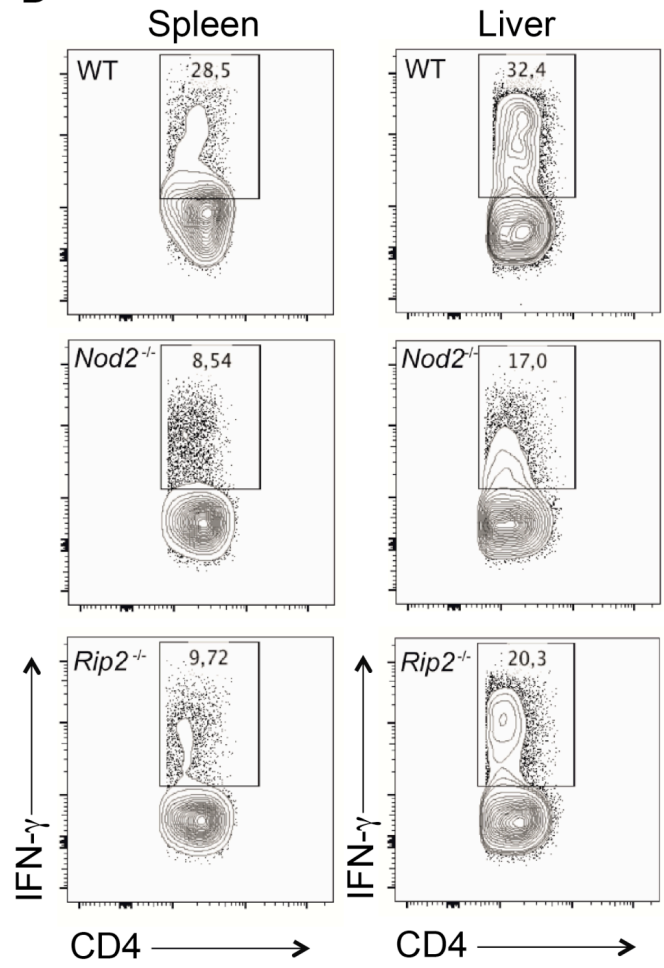


\section{Figure 4}

A
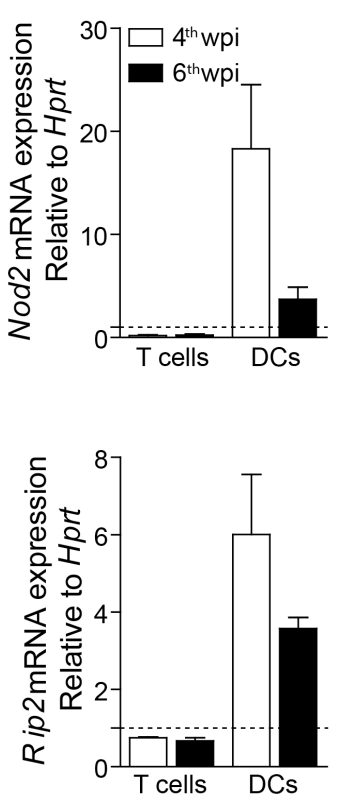

B
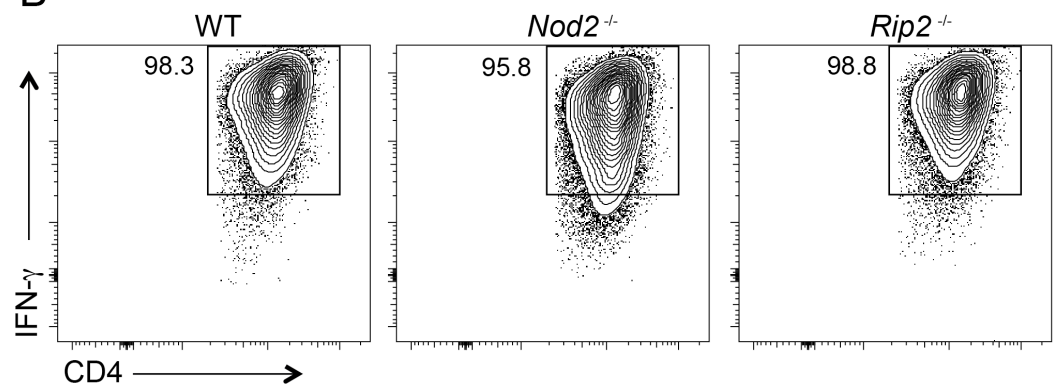

C
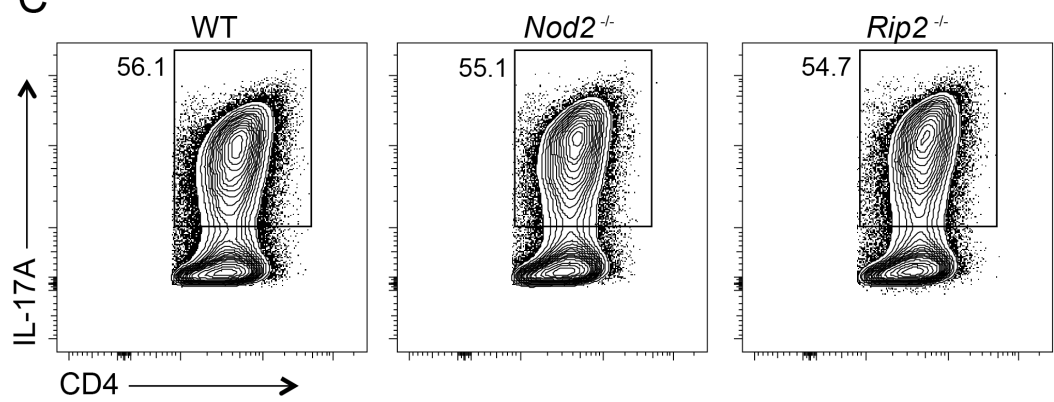

D
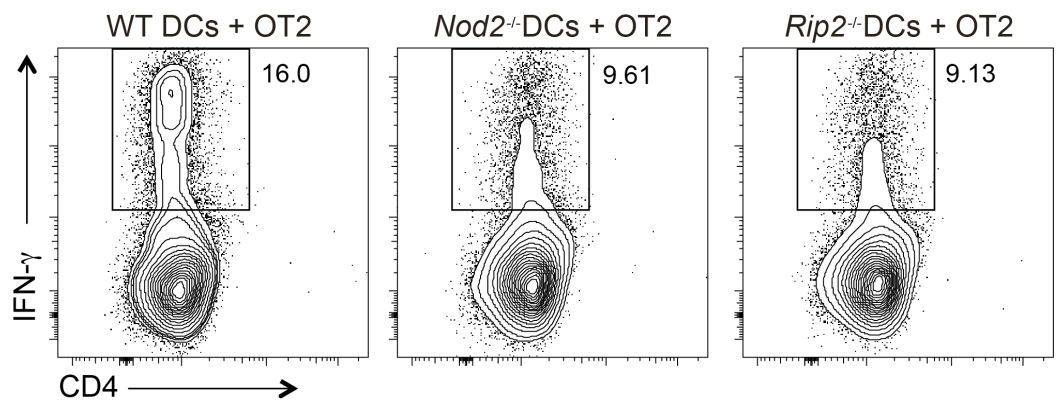

E

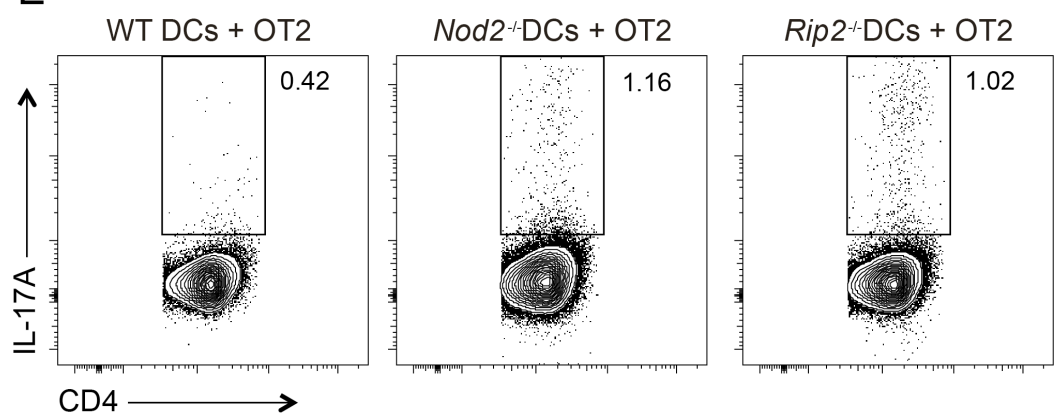


Figure 5

A

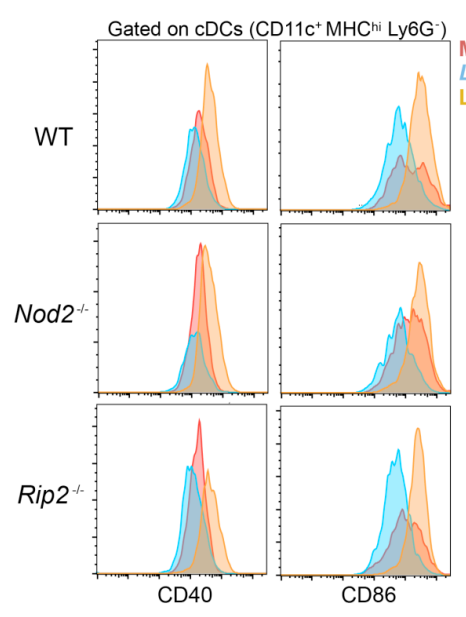

B

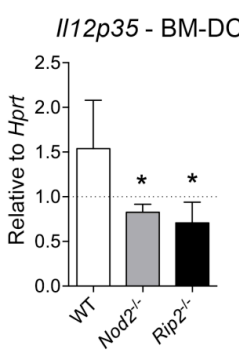

I/23p19 - BM-DC
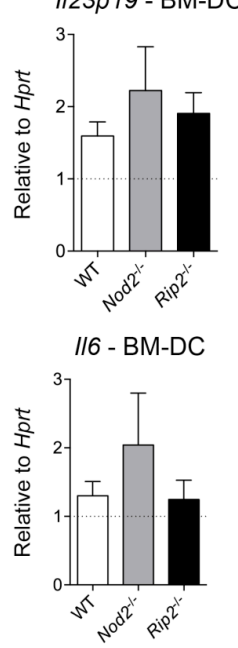
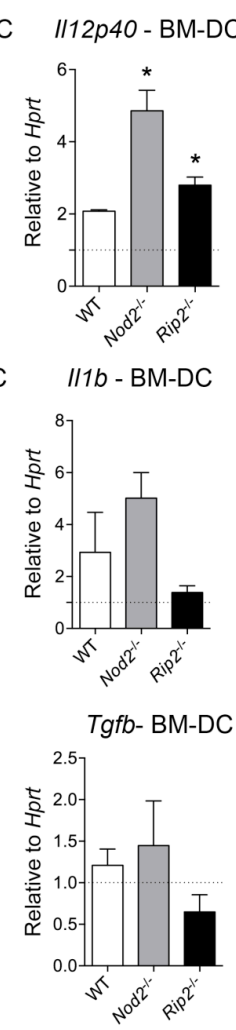

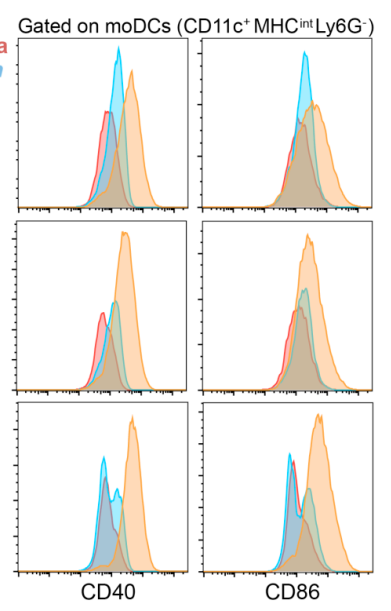

C
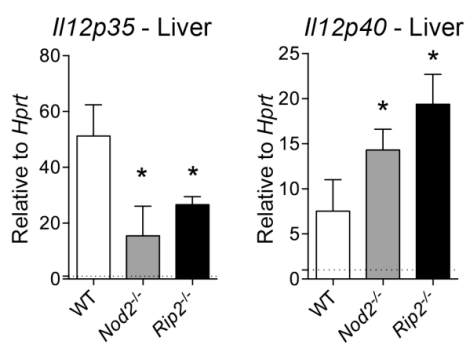

II23p19 - Liver
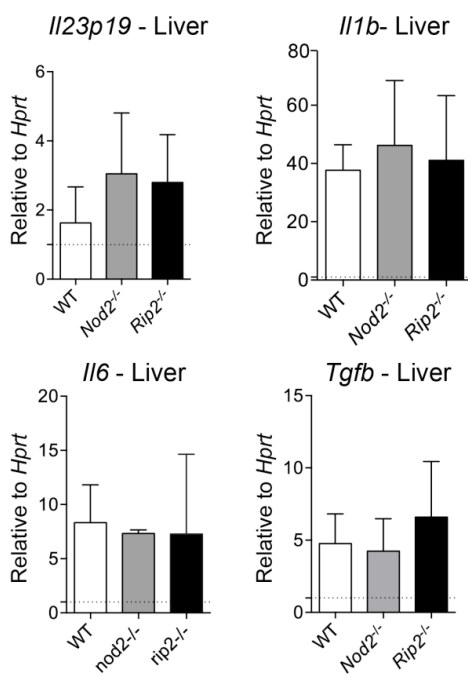

D
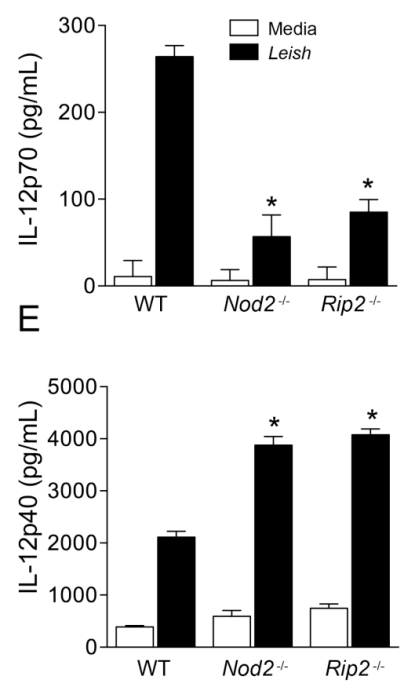

F
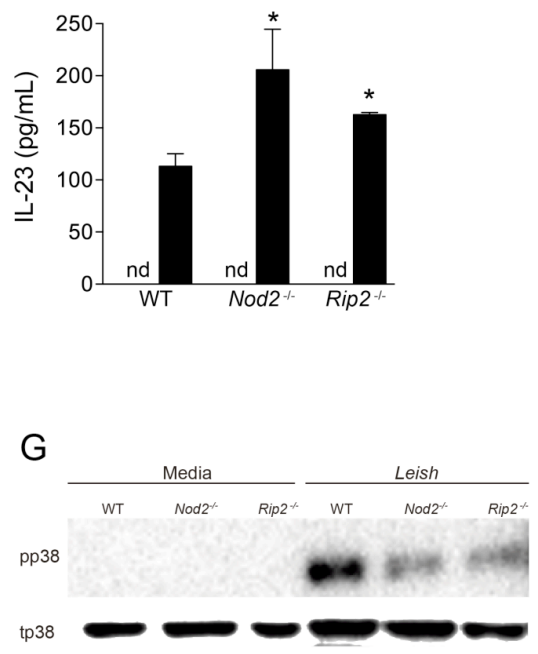

$\mathrm{H}$

pJNk

tJNK 
Figure 6

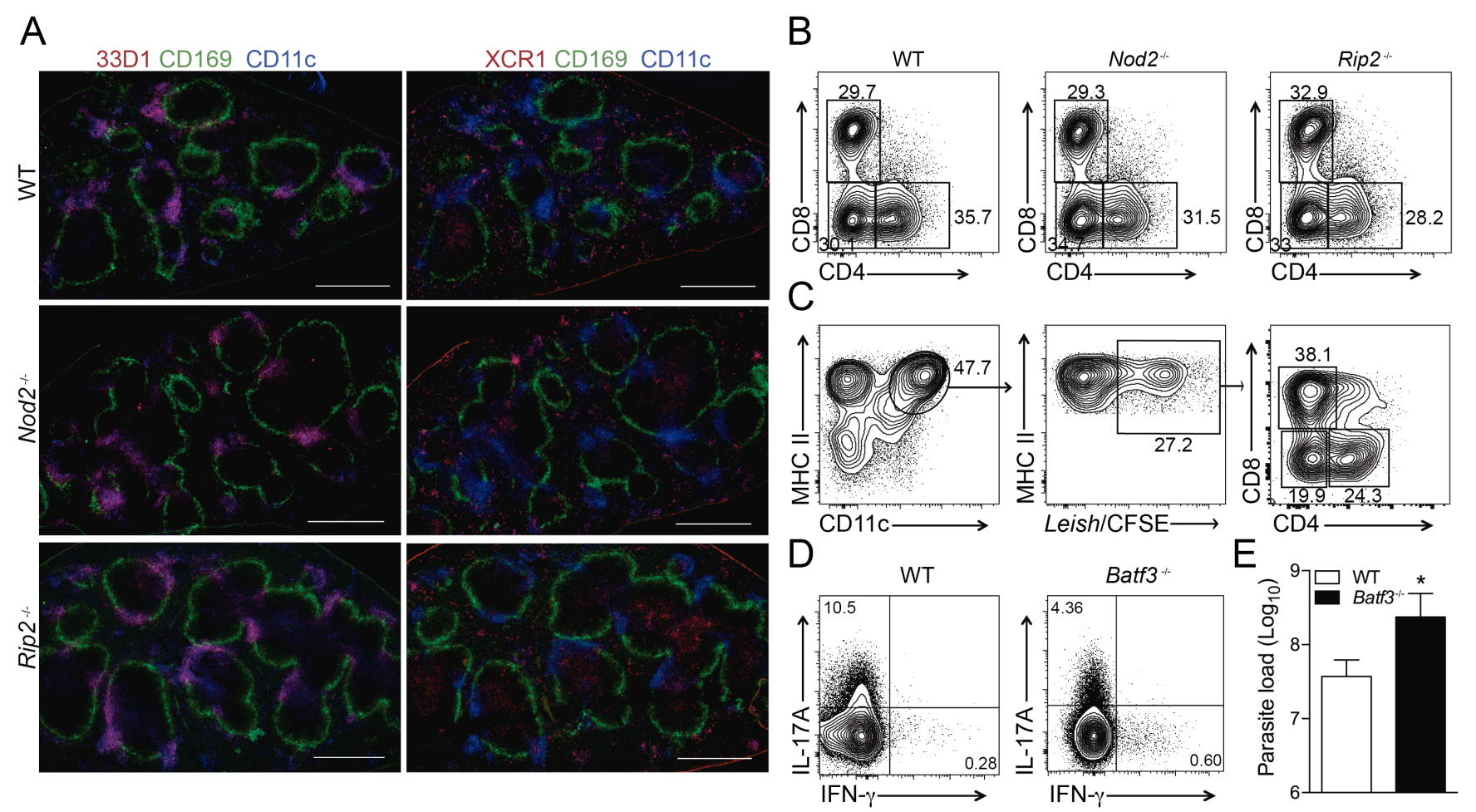




\section{Figure 7}

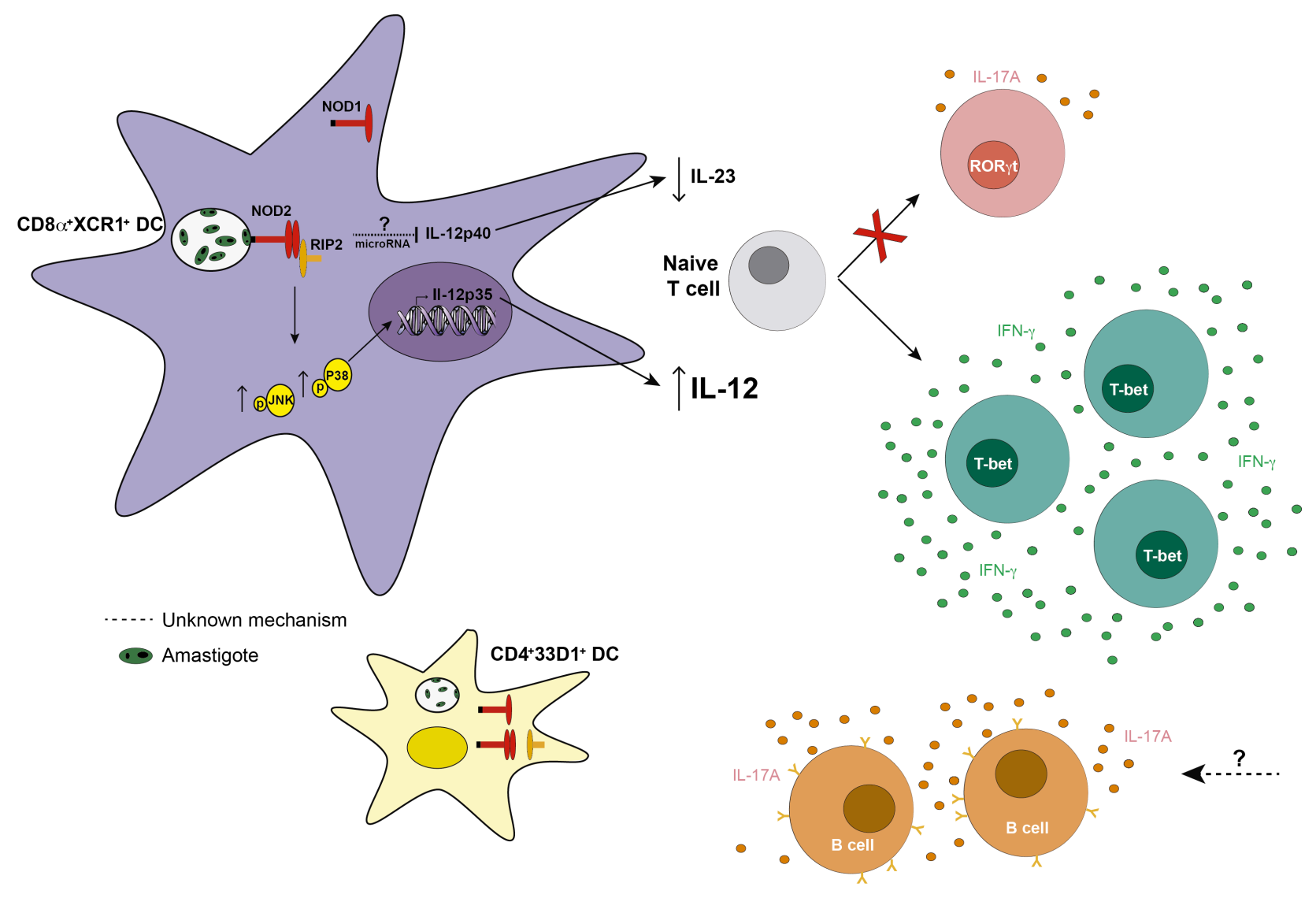




\section{Supplementary Figure 1}

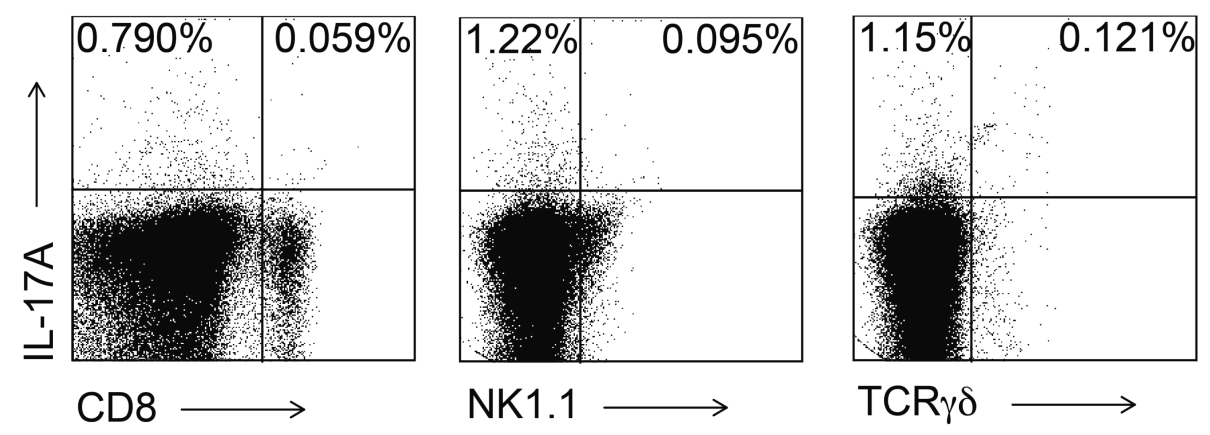


Supplementary Table I: Gene expression alterations at $4^{\text {th }}$ and $6^{\text {th }}$ wpi in the liver of C57BL/6 mice.

\begin{tabular}{|c|c|}
\hline Weeks post infection (wpi) & Gene with altered expression \\
\hline 4 wpi $\downarrow$ & Irf3; Rorc \\
\hline $6 \mathrm{wpi} \downarrow$ & Ccr6; II23a; II5 \\
\hline 4/6 wpi $\downarrow$ & Csf2; H2-Q10; Ifna2; TIr5 \\
\hline 4 wpi $\uparrow$ & Apcs; II1a; II4; Ly96; Stat3 \\
\hline 4/6 wpi $\uparrow$ & $\begin{array}{l}\text { C5ar1; Casp1; Ccl12; Ccl5; Ccr5; Ccr8; Cd14; Cd4; Ifng; Cd40; Cd40lg; Cd80; Cd86; } \\
\text { Cd8a; Cxcl10; Cxcr3; Fasl; Gata3; H2-T23; Icam1; Ifngr1; II10, Il13; II17a; II1b; II2; } \\
\text { Irf7; Tnf; Itgam; Jak2; Lyz2; Mpo; Mx1; Myd88; Nfkb1; NIrp3; Nod1; Nod2; Slc11a1; } \\
\text { Stat1; Stat4; Tbx21; TIr1; TIr2; TIr3; TIr4; TIr6; TIr7; TIr8; TIr9 }\end{array}$ \\
\hline
\end{tabular}

$\uparrow$, up-regulation. $\downarrow$, down-regulation. 